Portland State University

PDXScholar

Summer 8-12-2019

\title{
Reproduciendo Otros Mundos: Indigenous Women's Struggles Against Neo-Extractivism and the Bolivian State
}

Gisela Victoria Rodriguez Fernandez

Portland State University

Follow this and additional works at: https://pdxscholar.library.pdx.edu/open_access_etds

Part of the Latin American Studies Commons, and the Sociology Commons Let us know how access to this document benefits you.

\section{Recommended Citation}

Rodriguez Fernandez, Gisela Victoria, "Reproduciendo Otros Mundos: Indigenous Women's Struggles Against Neo-Extractivism and the Bolivian State" (2019). Dissertations and Theses. Paper 5094. https://doi.org/10.15760/etd.6970

This Dissertation is brought to you for free and open access. It has been accepted for inclusion in Dissertations and Theses by an authorized administrator of PDXScholar. Please contact us if we can make this document more accessible: pdxscholar@pdx.edu. 
Reproduciendo Otros Mundos: Indigenous Women's Struggles Against Neo-Extractivism and the Bolivian State

$$
\text { by }
$$

\title{
Gisela Victoria Rodriguez Fernandez
}

A dissertation submitted in partial fulfillment of the requirements for the degree of

\author{
Doctor of Philosophy \\ in \\ Sociology
}

\author{
Dissertation Committee: \\ José Padín, Chair \\ Daniel Jaffee \\ Aaron Roussell \\ Jeremy Spoon
}

Portland State University

2019 
(C) 2019 Gisela Victoria Rodriguez Fernandez 


\begin{abstract}
Latin America is in a political crisis, yet Bolivia is still widely recognized as a beacon of hope for progressive change. The radical movements at the beginning of the $21^{\text {st }}$ century against neoliberalism that paved the road for the election of Bolivia's first indigenous president, Evo Morales, beckoned a change from colonial rule towards a more just society. Paradoxically, in pursuing progress through economic growth, the Bolivian state led by President Morales has replicated the colonial division of labor through a development model known as neo-extractivism. Deeply rooted tensions have also emerged between indigenous communities and the Bolivian state due to the latter's zealous economic bond with the extractivist sector.
\end{abstract}

Although these paradoxes have received significant attention, one substantial aspect that remains underexplored and undertheorized is how such tensions affect sociopolitical relations at the intersections of class, race and gender where indigenous women in Bolivia occupy a unique position. To address this research gap, this qualitative study poses the following research questions: 1 . How does neo-extractivism affect the lives of indigenous women? 2. How does the state shape relations between neo-extractivism and indigenous women? 3. How do indigenous women organize to challenge the impact of state-led extractivism on their lives and their communities? To answer these questions, I conducted a multi-sited ethnographic study between October 2017 and June 2018 in Oruro, Bolivia, an area that is heavily affected by mining contamination. By analyzing processes of social reproduction, I argue that neo-extractivism leads to water contamination and water scarcity, becoming the epicenter of the deterioration of subsistence agriculture and the dispossession of indigenous lands and ways of life. 
Because indigenous women are subsistence producers and social reproducers whose activities depend on water, the dispossession of water has a direr and gendered effect on them, which demonstrates how capitalism relies on and exacerbates neo-colonial and patriarchal relations.

To tame dissent to these contradictions, the Bolivian and self-proclaimed "indigenist state" defines and politicizes ethnicity in order to build a national identity based on indigeneity. This state-led ethnic inclusion, however, simultaneously produces class exclusions of indigenous campesinxs (peasants) who are not fully engaged in market relations. In contrast to the government's inclusive but rigidly-defined indigeneity, indigenous communities embrace a fluid and dual indigeneity: one that is connected to territories, yet also independent from them; a rooted indigeneity based on the praxis of what it means to be indigenous. Indigenous women and their communities embrace this fluid and rooted indigeneity to build alliances across gender, ethnic, and geographic lines to organize against neo-extractivism. Moreover, the daily responsibilities of social reproduction within the context of subsistence agriculture, which are embedded in Andean epistemes of reciprocity, duality, and complementarity, have allowed indigenous women to build solidarity networks that keep the social fabric within, and between, communities alive. These solidarity networks are sites of everyday resistances that represent a threat and an alternative to capitalist, colonial and patriarchal mandates. 


\section{Dedication}

A mi mama, Felicidad Fernandez, por todas sus rebeldías y por recordarme siempre que la solidaridad empieza en casa, y es en el quehacer de cada día donde se crean las alternativas.

Munaycuyqui sonkituy, mama marimacho.

To my mom, Felicidad Fernandez, for all her rebeldias and for always reminding me that solidarity starts at home, and that it is in the everyday of life where we create alternatives. Munaycuyqui sonkituy, mama marimacho. 


\section{ACKNOWLEDGEMENTS}

"You never know the effects your actions will have on someone: even just a single individual, and the way that can ripple into the world"

(Glenn Greenwald on the assassination of Marielle Franco)

Knowledge is a collective process, and as such, this dissertation is a collaborative work that reflects the commitment and compromise of the many people who helped and guided me through this journey, both academically and personally. Due to IRB requirements of confidentiality, unfortunately I cannot write the real names of the people I worked closely with in Bolivia. While this is a requirement to project human subjects, it also makes the very actors who deserve the most recognition invisible, which is a paradox, especially for qualitative studies, and this requires further discussion. I also cannot thank every single person who supported me in this process, as the list is too long, but you know who you are; thank you.

First and foremost, I want to thank the participants in this study, particularly the women who shared their stories with me. I am honored to have shared time and space with them and I am forever thankful to them for showing me how to walk the talk, from Doña Paula who offered me a place to stay in the Kochi Piacala community without knowing me and without asking anything in return, to Doña Silvia who also supported me unconditionally. It is in these everyday solidarities that a different system is created. Thank you for offering a different and alternative way of being and relating to the world around us. I want to thank CORIDUP and CEPA, whose members welcomed me from the very start and whose support was key in the fulfillment of my fieldwork. I am especially thankful to Don Miguel from Kochi Piacala for his integrity and coherence in thoughts, feelings and actions. From the very start Don Miguel welcomed me as a 
hermana, a sister in struggle, and offered me all the support I needed. It was also a great pleasure and honor to work with the Wasi Pacha collective. I am especially thankful to them for their efforts and actions to raise awareness about the local realities in Oruro, Bolivia and for showing all the richness this region has; gracias mil muchachxs, abrieron otros ojos en mi conciencia. This gratitude extends to Las Ramonas for their engagement in similar work.

My adviser Dr. José Padín devoted so much time supporting my work and development as a scholar while simultaneously challenging me to do and be better, all while embracing our shared Latinidad. It was in Dr. Padín's theory class that he introduced me to black feminist theory and this marked my path as a scholar forever, thank you so much for such a critical class. By pushing my limits and affirming my strengths (not to mention the endless meetings and revisions of very rough drafts), Dr. Padín supported me to navigate this process in my own terms, to become who I wanted to become, and I am forever thankful for his trust in who I am, and in what I believe. Dr. Padin embodies what an adviser should be. Gracias profe Padin. I also want to thank Daniel Jaffee, Jeremy Spoon, and Aaron Roussell, all of them members of my doctoral committee from Portland State University (PSU), for working with me. Dan, thank you very much for the globalization class, it not only helped me find my dissertation topic, it also helped me to be critical of the harsh realities at home, and it reminded me that my commitment is to the people, not to ideologies. Jeremy, our conversations about what indigeneity means, theoretically and personally, assured me that this endeavor was worth it and that I had something to contribute; thank you. And Aaron, you exemplify the connection between theory and praxis that often times academia misses, thank you for 
showing me the way. I have been very lucky to have such an incredible academic and collegial support.

I am immensely grateful to my family and friends in Bolivia as well as in the US, especialmente agradecida a mis hermanos Jaime, Johnny, Gonzalo, mi sobrinxs zebras Grecia y Darko, a Doña Sera, mis primos hermanos Carla, Carlos and Americo, and my best friend Monica. Without their love, support, the food and the parties they organized to celebrate life, I would not have been able to cope with the difficulties that many times fieldwork and life brought to me. I am also grateful to my dad Jaime and brother Jorge, who departed a long time ago but whose energies accompany me everyday. Thank you for those coincidences, I know it was you. And Jorgito, gracias por enseñarme a valorar mi otredad, cada baile es una celebracion para ti. And thanks Morgan, aka Dr.

Fieldmouse, for your startling vibes and your unconditional support; the winter solstice put you in my path to remind me why I am doing this. Omar Melchor, as you said, eres de los mios, and our shared experience as Latin immigrants within the PhD program kept me sane, y me dio mucha alegria, gracias. Susan Kolodin, thank you for all your support and for constantly assuring me I can do and thrive doing this. Osman from Cochabamba reminded me of the healing powers of the coca leaf and sparked some new inspiration into my life, gracias por existir. And thank you Rick, for you too played an important and supportive part in ways you might not even realize. House music was the medicine my soul needed, thank you for this. Our paths might split, but our connection continues.

I have no words to thank my mom Felicidad, Happiness, and as her name states, she has been nothing but a pure joy in my life. She might be tiny like an ulupika, a tiny Bolivian pepper that is very spicy, but her strength is in her incredible commitment to 
life, to the world and everything that surrounds her, including people, plants and animals. It is strange how life works. Without planning for it, my fieldwork was at el Altiplano, the same place where my mom spent her childhood. She grew up there during a time when indigenous values and epistemes of reciprocity combined with the Marxist tradition of solidarity fostered the creation of the most radical workers' union in Bolivia and Latin America at that time. And there is something very profound in these connections and the way my mom embodies them.

Like many women in Bolivia, my mom had to carry the brunt of the violence that patriarchy and capitalism depend upon, becoming a single mother of five in the $80 \mathrm{~s}$, the time when neoliberal policies were fully implemented in Bolivia, then becoming an exile of neoliberalism. But my mom's rebellious spirit defied this reality; rather than accepting a destiny as a victim of the system, she embraced her life in her own terms, took risks, and like many other immigrants, she came to the US with a dollar in her pocket and many dreams to fulfill by taking any opportunity to disobey the capitalist and patriarchal mandates in small and not so small ways. Gracias mamita, estoy tan agradecida a la vida por tenerte a mi lado y por todas nuestras rebeldías. 


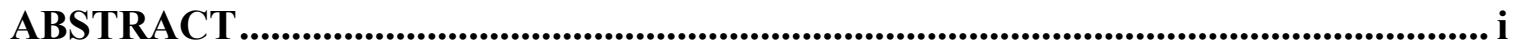

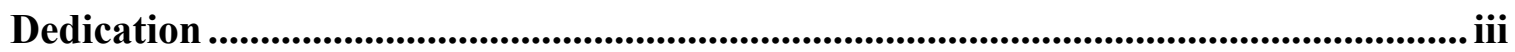

ACKNOWLEDGEMENTS ................................................................................... iv

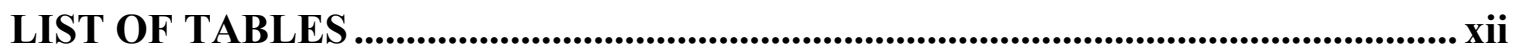

LIST OF FIGURES ....................................................................................................... xiii

LIST OF ABBREVIATIONS ............................................................................... xiv

GLOSSARY OF SPANISH, QUECHUA AND AYMARA TERMS ......................... xv

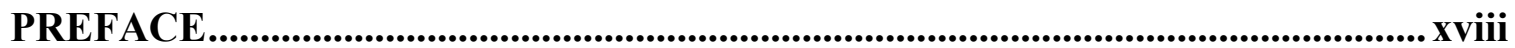

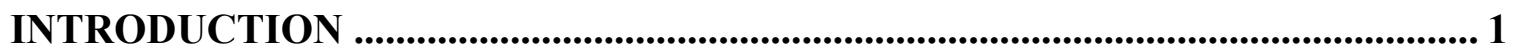

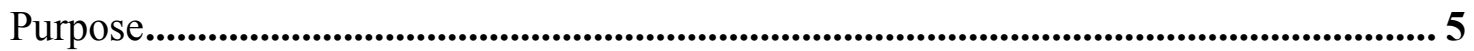

Research questions ................................................................................................................ 6

Background: A brief history of Bolivia................................................................................ 8

Evo Morales and el Movimiento Al Socialismo (MAS)...................................................... 13

Fieldwork setting .................................................................................................................. 15

Key findings.................................................................................................................................... 17

Contributions of this research ............................................................................................ 19

Organization and structure of this dissertation ................................................................. 21

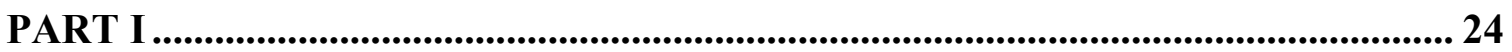

CHAPTER ONE LITERATURE REVIEW ............................................................. 25

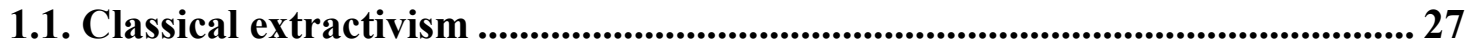

1. 2. Neo-extractivism .................................................................................................. 28

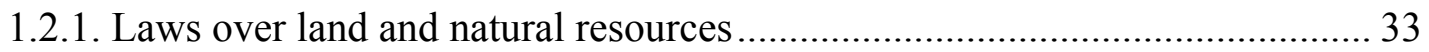

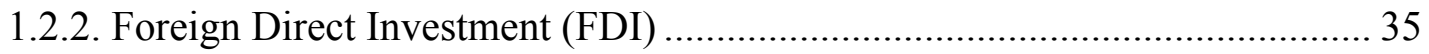

1.3. Neo-extractivism and indigenous communities..................................................... 36

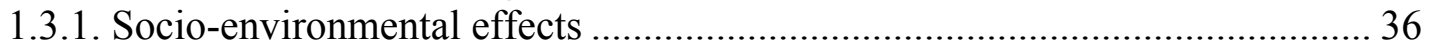

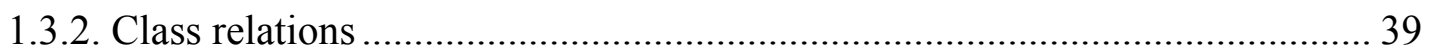

1.4. Neo-extractivism and indigenous women ....................................................40

1.4.1. Artisanal and Small Mining (ASM) ......................................................... 40

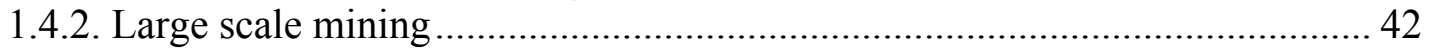

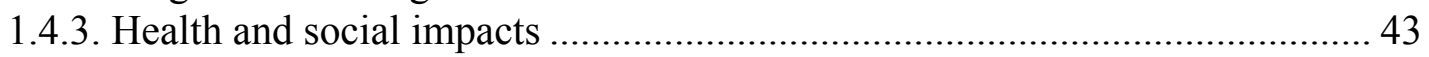

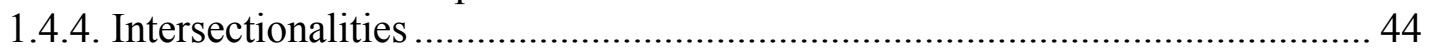

1.4.5. Indigenous women's responses to neo-extractivism..................................... 46

1. 5. The state and political identities ..........................................................................5 50

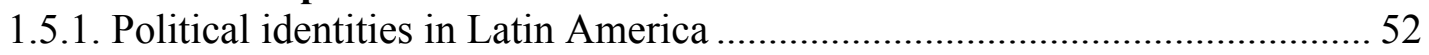

1.5.2. Political identities, neo-extractivism and the state.......................................... 53

CHAPTER TWO THEORETICAL FRAMEWORK...............................................59 
2. 1. Structural mechanisms of the state ........................................................................62 62

2. 2. World systems theory and the commodities consensus ...................................... 64

2. 3. Accumulation by dispossession .....................................................................68

2. 4. Political identities and indigeneity in the Bolivian context ................................. 71

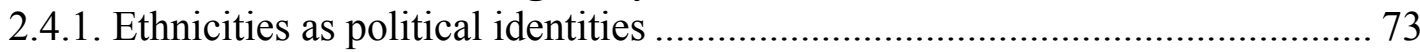

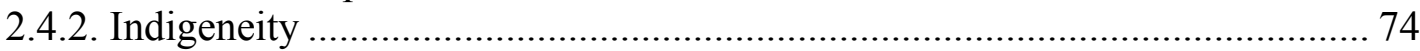

2. 5. Social Reproduction Theory (SRT) ....................................................................... 79

CHAPTER THREE FIELDWORK SETTING, DATA AND METHODS ................ 83

3.1. Fieldwork setting........................................................................................................ 84

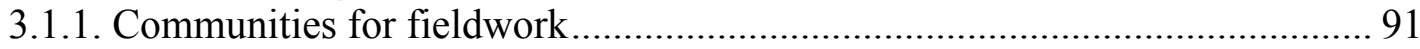

3.1.2. The Huanuni mine: "sangre de minero, semilla de guerrillero" ...................... 99

3. 2. Data and methods ...................................................................................................... 102

3.2.1. Focused multi-sited ethnography …………….......................................... 102

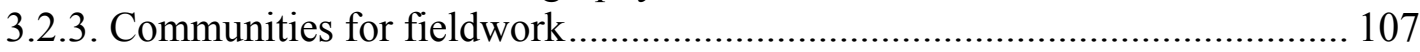

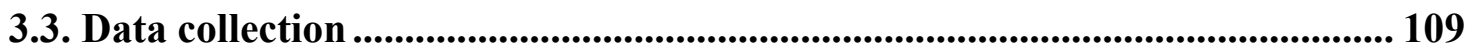

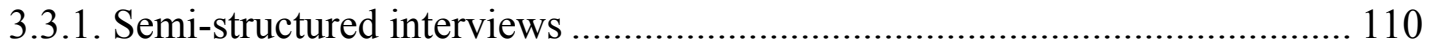

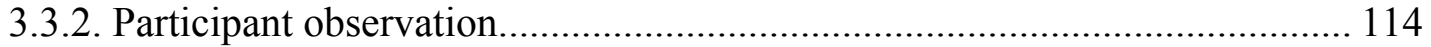

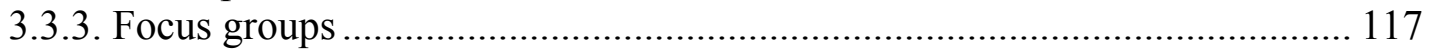

3.3.4. Sampling strategy and participant recruitment .......................................... 119

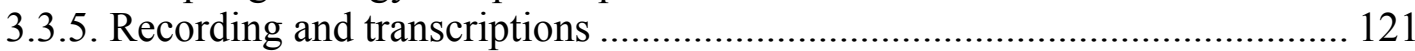

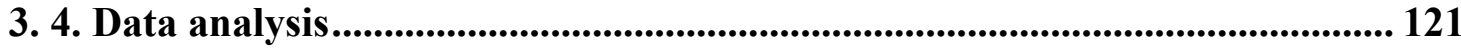

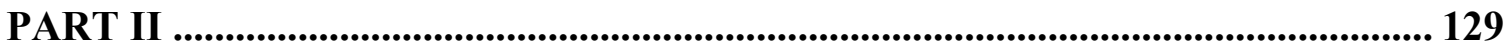

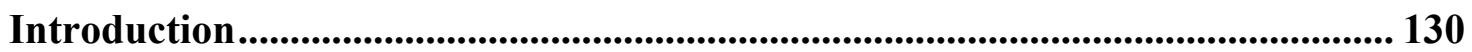

CHAPTER FOUR NEO-EXTRACTIVISM EFFECTS ON THE LIVES OF INDIGENOUS CAMPESINX WOMEN ................................................................... 133

4.1. Rural diasporas back and forth ................................................................................ 135

4.1.1. Natural and not so natural reasons for the rural diasporas ............................ 137

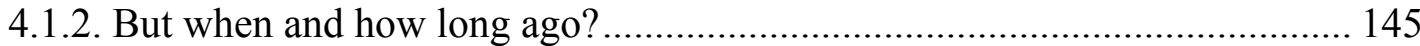

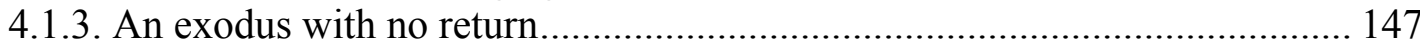

4.1.4. Lucia and Papucho: on the relationships with animals ................................ 149

4. 2. "Sin agua no hay vida" [There is no life without water].................................. 151

4.2.1. Visible and invisible consequences ........................................................... 157

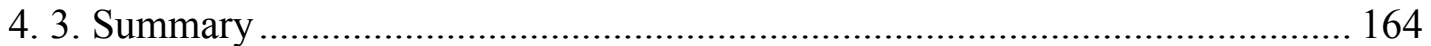

CHAPTER FIVE THE STATE AND NEO-EXTRACTIVISM,

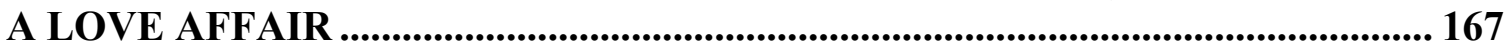

5. 1. The legal framework of contradictions ................................................................. 169

5.1.1. Supreme Decree 0335 of 2009 ............................................................... 170

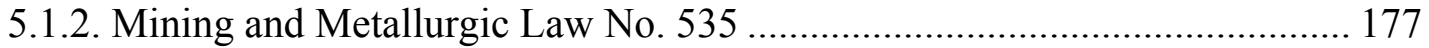

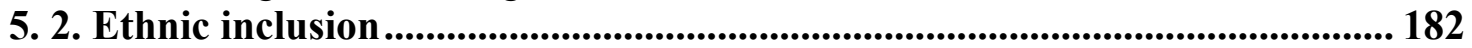

5.2.1. "But...there is always a 'but' right?"......................................................... 188

5.2.2. From ethnic inclusion to class exclusions.................................................. 197

5. 3. Divide and conquer ..................................................................................................... 201 
5.3.1. "Si eres del MAS te va bien" [if you are from MAS you will do well]........ 209

5. 4. Bureaucratization of life..................................................................... 217

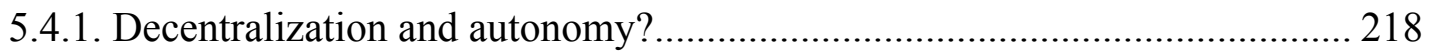

5.4.2. Bureaucratization and grassroots organizations..................................... 222

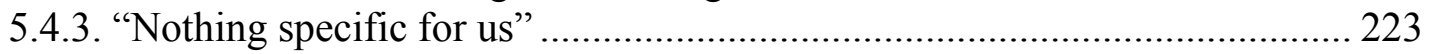

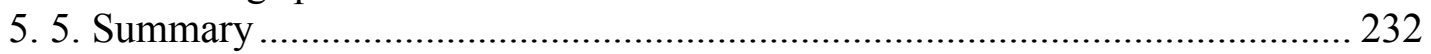

CHAPTER SIX RESISTENCIA ................................................................................ 234

6. 1. Resistiendo aqui y ahora [Resisting here and now] .................................... 236

6.1.1. Resistencia popular [Popular resistance] ................................................. 236

6.1.2. Resistencia de cada día [Everyday resistance]....................................... 238

6. 2. Redes de solidaridad: solidarity networks................................................ 239

6.2.1. Entretejiendo espacios [Interweaving spaces] ......................................... 244

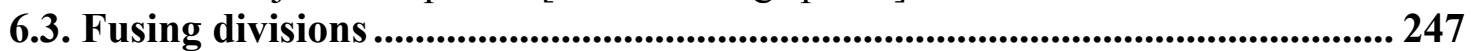

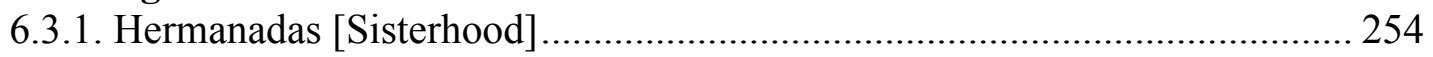

6. 4. It is chacha-warmi, not warmi-chacha ........................................................ 257

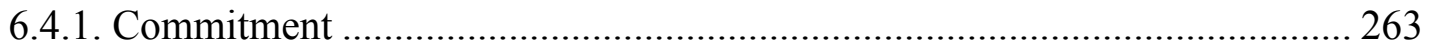

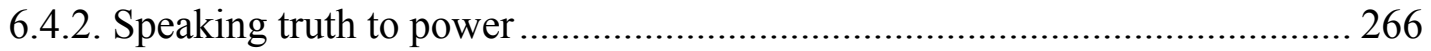

6. 5. Creating the impossible ..................................................................... 269

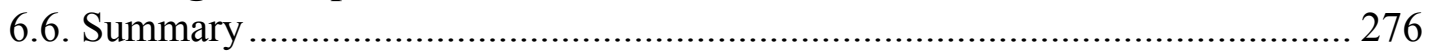

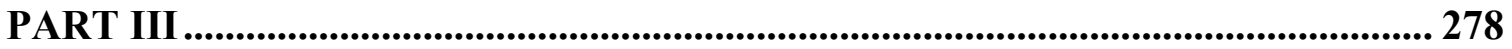

CHAPTER SEVEN ANALYSIS AND DISCUSSION ...................................... 279

The political economy of neo-extractivism ........................................................... 284

7.1. Neo-extractivism and the agrarian question .............................................. 286

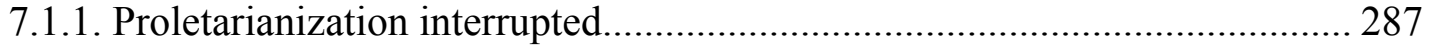

7.1.2. Concealed land grabs ........................................................................... 290

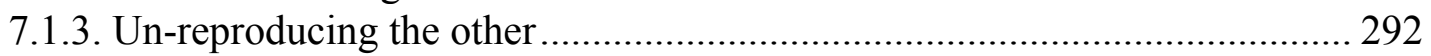

7.2. Water is social life ............................................................................................ 295

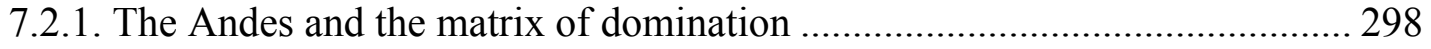

7. 3. Different face, similar neoliberal effects ................................................... 301

7.3.1. El gatopardismo del MAS: to change everything in order to change nothing

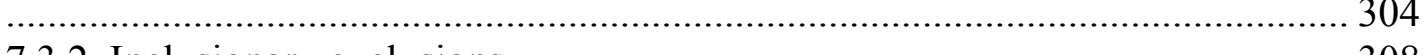

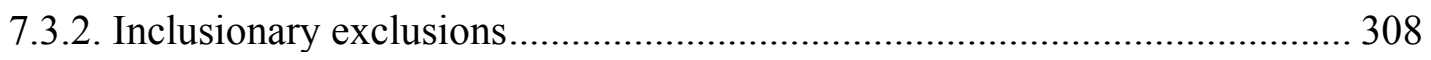

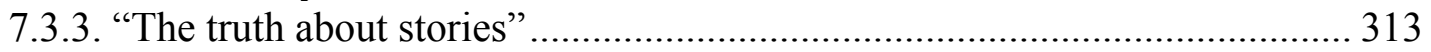

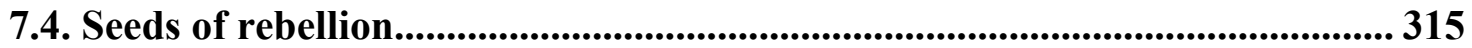

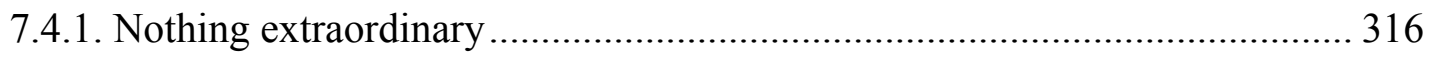

7. 5. Reproduciendo otros mundos [reproducing other worlds]........................... 320

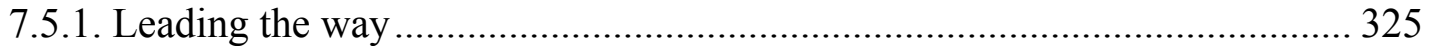

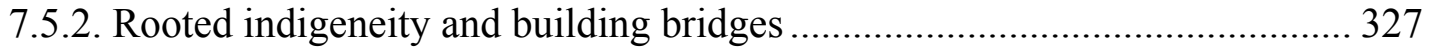

7.5.3. The other Sumaq Qamaña...................................................................... 330

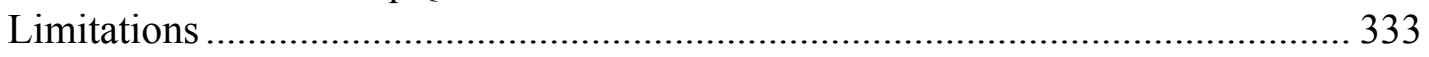

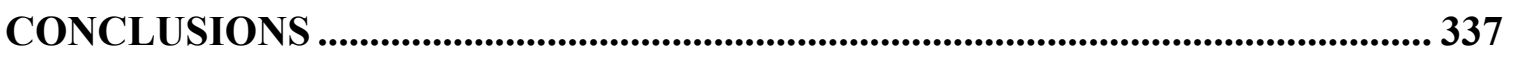

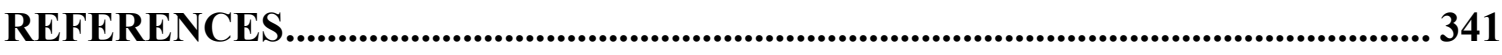


Appendix A. Informed consent forms for all participants............................................. 368

Appendix B. Verbal script for recruitment ....................................................................373

Appendix C. Interview guides............................................................................................... 378 


\section{LIST OF TABLES}

Table 1. Extreme poverty and social inequality: 1999; 2012; 2018 .......................... 15

Table 2. Characteristics of the communities in this study.......................................... 98

Table 3. Socio-economic characteristics of the municipalities for fieldwork ............... 109

Table 4. Demographic characteristics of participants. ............................................ 113

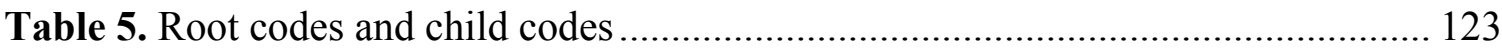

Table 6. MML 535 and six articles relevant for this study .................................... 177

Table 7. Divide and conquer strategies of the MAS government .............................. 203

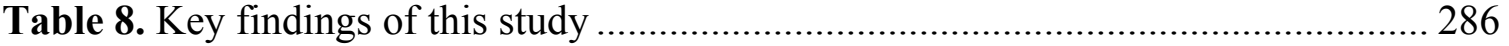




\section{LIST OF FIGURES}

Figure 1. Research orientation on neo-extractivism and the state in Latin America ......... 7

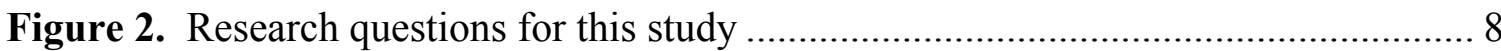

Figure 3. Mining concessions in Bolivia and geographical location of fieldwork ........ 17

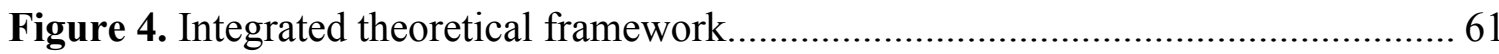

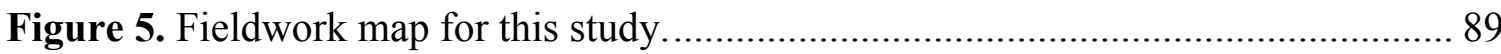

Figure 6. Communities for Fieldwork, Oruro, Bolivia.............................................. 93

Figure 7. Ayllus, Markas and Suyus: Nations within a nation .................................... 95

Figure 8. Kochi Piacala community ........................................................... 135

Figure 9. Women selling food on the streets of Oruro city................................... 142

Figure 10. Los Urus del Lago, Indigenous Peoples of Lake Poopó.............................. 145

Figure 11. Wijiñas in the Kochi Piacala community with contaminated water............ 155

Figure 12. Getting water in the Machacamarca municipality .................................. 160

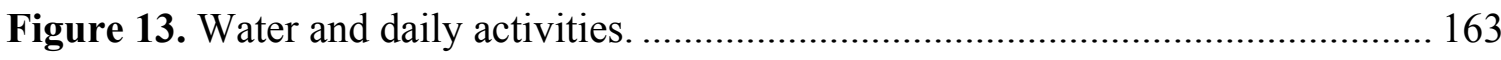

Figure 14. CORIDUP in a meeting with state officials. ....................................... 192

Figure 15. CORIDUP Meeting with state officials in La Paz, Bolivia....................... 226

Figure 16. Meeting of the Ayllu Puñaka in Poopó, Oruro ........................................... 244

Figure 17. Wasi Pacha seminars and workshops ................................................. 250

Figure 18. Sartañani Wasuru Qhananpi, Cultural and Autochthonous Center............. 254

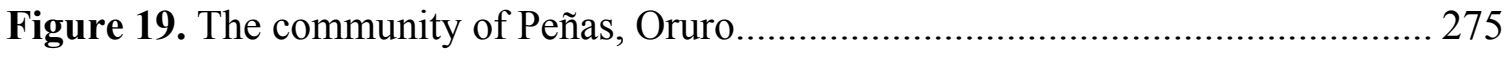




\section{LIST OF ABBREVIATIONS}

$\mathrm{AbD}$

ASM

Catapa

CEPA

CONAMAQ

CORIDUP

CPE

MAAyA

MAS

MDRyT

MERCOSUR

MHE

MIDR

MML 535

NGO

PCP

SD 0335

SRT

TCOs
Accumulation by Dispossession

Artisanal and Small Mining

A Belgium environmental and social grassroots organization for alternative globalization and sustainable development

The Center for Ecology and Andean Communities. A local NGO that works with indigenous communities in the Andes

The National Council of Ayllus and Markas of Quollasuyu

The Desaguadero River, Uru and Poopó Lakes Defense

Coordinator

La Nueva Constitución Política del Estado (CPE) [The New Bolivian Constitution]

The Ministry of Environment and Water

Movimiento Al Socialism [Movement Towards Socialism], the political party of Evo Morales

Ministry of Rural Development and Territories

Mercado Comun del Sur [Southern Common Market]

Ministry of Hydrocarbons and Energy

Mining Induced Displacement and Resettlement

Mining and Metallurgic Law 535 of May 2014

Non-Governmental Organization

Proyecto Cuenca Poopó [Poopó Basin Project]

Supreme Decree 0335 that declares the Huanuni sub-basin as an environmental emergency zone

Social Reproduction Theory

Tierras Comunitarias de Origen [Communal Indigenous Lands] 


\section{GLOSSARY OF SPANISH, QUECHUA AND AYMARA TERMS}

The Andes

El Altiplano

Akullico/

Acullico

Alantañita

Ayllu

Ayni

Buen Vivir

Campesinx(s)

Canchas de

Futbol

Ch'ixi

Chacha-Warmi

Comunarix (s)

Conciencia

Copagira

Cosecha de Agua

Cosmovision

Doble

Residencia
The continental mountain rage that forms a continuous highland in the western edge of South America.

The wide, mostly-flat region of the Central Andean Plateau that is found between the towering mountains of the Eastern and Western Cordilleras of the Andes.

A traditional and social practice where people share and chew coca leaves symbolizing kinship.

A rural and indigenous community in the Machacamarca municipality and one of the four communities identified for this study.

An indigenous organizational structure that co-exists with the national administrative divisions.

An Andean socio-economic system based on reciprocity, complementarity and kinship.

\section{See Sumaq Qamaña}

Peasant(s). The ' $\mathrm{x}$ ' is used to make the language inclusive and gender neutral.

Soccer fields

Aymara word meaning stain, something that is unable and unwilling to mix but relies on such tensions to build. Used by Bolivian sociologist Silvia Rivera Cusicanqui to challenge and replace the notion of mestizaje.

Man and Woman, and Andean indigenous notion of complementarity.

From the community: People who are from and live permanently in rural and indigenous communities. The ' $x$ ' is used to make the language inclusive and gender neutral.

Consciousness, here representing an awareness and practice of one's social position within society. It also means conscience, in reference to notions of integrity and morality

Acidic liquid runoff from the mines

Water harvesting techniques

Worldview

Double residency, a pattern in which people from the communities live usually in a nearby town/city but go back to their communities during the weekends to take care of their lands. 
Don/Doña

Gatopardismo

Habas

Hermana(o)

Huayanca

Huanuni

Indian

Jilakata

K'aras

Katarismo

Kochi Piacala

Las Ramonas

Machacamarca

Mama T'alla

Manta

Marka

Masistas

Mestizaje

Mestizaje

Pacha
Mr. and Mrs., denotes respect for older people

To change everything in order to change nothing: A word in reference to political strategies that in theory are revolutionary but in practice represent minimal modifications to existing structures.

Fava beans

Sister/brother. In the context of Bolivia, hermana(o)is used to signify likeness and trust.

An Andean practice to give to one's neighbor the best seeds with the understanding that this will help one's own seeds.

The name of the city, river, municipality and mine with this name.

Denote the traditional subordination this term implies. In this study this word is also used in its colloquial form to denote an unruly character, therefore highlighting this forbidden attitude that is active and unwilling to be oppressed.

Maximum indigenous leader of an Ayllu.

A word to refer to white looking people

An indigenous movement in the 1970s in honor of Tupac Katari, with decolonization as its political agenda.

A rural and indigenous community in the Machacamarca municipality and one of the four communities identified for this study.

A feminist collective from the city of Cochabamba, Bolivia

A Municipality and a town in the department of Oruro.

Female indigenous leader

Indigenous shawls

An indigenous organizational structure that consists of a group of Ayllus.

Belonging to the MAS party

From mestizo, a word in reference to people of European and indigenous American descent.

A state project to create a national, general citizenship

An Aymara word that comes from Paya (two) and Cha (strength) meaning a duality of forces between time and space. Pacha also means earth. 
Pachakutik

Pachamama

Pollera

Poopó

Proceso de

Cambio

Puñaka

Quellia

Residente

Sumaq Qamaña

Suyus

Tata Mallku

Tinglados

Totora

Oruro

Wasi Pacha

Wawas

Wijiñas
An Andean notion in reference to the time-space notion of transformation that points to ongoing patterns of change where the past coexists in the present to determine the future.

Mother earth

Indigenous skirt, also used in reference to indigenous roots, particularly for women.

The name used for the lake, basin, town and municipality with this name that are located in the department of Oruro.

Process of change: The period from 2000 to present which includes all the policies and projects aimed at making Bolivia a plurinational nation based on the philosophy of Sumaq Qamaña, as opposed to living under exploitation and oppression

A rural and indigenous community in the Poopó municipality and one of the four communities identified for this study

A rural and indigenous community in the Poopó municipality and one of the four communities identified for this study

People who have lands in a rural and indigenous community, but live somewhere else, usually in urban towns or cities.

[Buen vivir, living well] the indigenous philosophy of living in harmony with nature and with one another, which emanated from the Andean episteme of life as a relational process, based on the notions of duality, reciprocity and complementarity, as well as a serious questioning of economic development, modernity and progress.

An indigenous organizational structure that consists of a group of Markas

Male indigenous leader

Shed structures for community-oriented activities

Local sedge

The name of the city and department with this name

The house of earth, an environmental activist collective from the city of Oruro, Bolivia

Quechua word for babies

Ancestral man-made water deposits with a conic form 


\section{PREFACE}

Gloria Anzaldúa's writing on borderlands refers to the visible and invisible borders that exist among the peoples who cohabit in the in-betweenness of such spaces (2012). I reflect on Anzaldúa to understand how my own identity and my own perceptions have shaped this research and my role as a scholar. Who says what, and from what position, matters too.

I am Bolivian and colla (people from the Altiplano) like a chuño, a freeze-dried potato typical from the Andes. I grew up in la zona periferica, literally at the outer limits of the city of La Paz, Bolivia. What this means is that this research is about home, my family and my roots. It is about the Indian question, a question about a part of my identity that I tried so hard to erase and that now I embrace. ${ }^{1}$ It is about mestizaje, being a mestiza, a "mix", which often means to acknowledge our European legacy, while rejecting our Indigenous roots. It is about Mestizaje as a state project to erase these indianness to create national, general citizens.

The topic of indigeneity is therefore a central issue I explore in this dissertation. For this reason, I have to constantly check myself to make sure I keep enough distance from my research and from participants in order to not romanticize them. I am also insistent that I have to make sure I keep enough closeness to my research and to the participants in order to not rationalize them. It is interesting that we as scholars are often reminded not to romanticize indigenous people, as it should be, since apparent benevolent

\footnotetext{
${ }^{1}$ Throughout this study, I often use the word "indian" and not indigenous to denote the traditional subordination this term implies (Hale, 2004). Other times, such as in this reference, I use "indian" in its colloquial use to denote an unruly character. In Bolivia, "indian" is used discriminatorily to refer to indigenous people with an uppity attitude; indigenous people on the other hand, embrace the word indian as an attitude that stands against the assumption that they are supposed to be submissive. "Indian" therefore highlights this forbidden attitude that is active and unwilling to be oppressed.
} 
ideologies such as the "noble savage" have perpetuated colonial and racist ideologies. At the same time however, we rarely question the myriad ways that we rationalize people; how logic, positivism and Western rationality ignore other epistemologies and label them as folklore just because they seem too mystical, or not rational enough for Western eyes (Mohanty, 2002).

I am also a Latinx immigrant, I am the South within the North, and as a scholar in the US, I belong to the Western empire of knowledge extraction and production, which like extractive capitalism, removes raw 'outputs' from the communities in the Global South to then transform them into academic 'knowledge' from the North (Grosfoguel, 2016). This poses a soul-searching question: who I am as a scholar, who I represent, and how I do it. Bolivian sociologist Silvia Cusicanqui argues that in Aymara cosmovision, dualities do not to seek harmony or a synthesis but rather they thrive on tensions that are the drive that maintains motivation. Instead of mestizaje, she refers to $C h$ 'ixi, an Aymara word meaning stain, something that is unable and unwilling to mix but relies on such tensions to build. The in-betweenness of who I am as a person and as a scholar helps me to redefine what borders mean and why it is a serious critical endeavor to leave aside essentialisms. Doing research in a place with people who are so close to home forces me to be even more critical and objective towards these issues because to me they have faces and names; they have histories so intertwined to mine. Moreover, being objective does not mean to be neutral (Cusicanqui \& De Sousa Santos, 2015). I am objective in that my research is based on evidence and critical analysis, yet I do not pretend to be neutral. I am not. I know which side I belong to and my goal is not to just describe the social world around, but to change it, hopefully for the better. In doing this, it is very likely I will 
reproduce the very hierarchies I aim to destroy and that I might continue colonial representations and logics. As Asher (2017) states, representation is inevitable, therefore "we must... confront how we are shaping others through those representations so as to reinforce the images and fantasies of the colonial as well as the not-yet-decolonialized imaginary" (p. 518). I am also reproducing the extraction of knowledge from the Global South to the Global North. One way to hopefully mitigate these contradictions is to directly ask participants what they think about my own interpretation of their lives. Participants did complain that very often outsiders come and ask all types of questions and then they disappear, leaving them with no answers, no solutions and a feeling of disrespect. In August this year (2019) I am going back to Bolivia to present the findings of this study to the participants and communities that offered me such crucial insights. I am also going to prepare a summary of this dissertation for the communities to help them document the effects of mining contamination. This is the minimum, first step to address these issues.

About my writing style, I often use Spanish, Quechua and Aymara words and phrases. I do this purposely to follow the style of Gloria Anzaldúa's code switching to reflect my way of thinking as an immigrant as well as to reflect the stories of the people I interviewed, who also played with words and phrases between Spanish, Quechua, and Quechuañol (a mix of Quechua and Español). By doing this, I also want to challenge the idea that "the only legitimate form of writing is in a single language" (Jordan, 2018, p. 104). Colloquial academic parlance sometimes is too rigid and dry to capture the flavors, colors, complexities and feelings that analyzing social life requires. Therefore, my 
writing style, while still serious and rigorous, aims to be less rigid in hopes to capture some of the richness of the lives of the people I encountered. 


\section{INTRODUCTION}

"Naya saparukiw jiwyapxitaxa nayxarusti, waranqa, waranqanakaw tukutaw kut'anipxani..." [Today you kill me, but tomorrow I will come back and I will be millons] (Tupac katari)

Indigenous peoples in Bolivia, in despite of being the majority of the population, have experienced ongoing oppressions and exploitation. Class-based exclusions and ethnic divisions have been the modus operandi from colonialism through the present, where Bolivia remains one of the most unequal countries in the region (Cusicanqui, 2014; Webber, 2015). The history of Bolivia however, is also defined by ongoing insurrections centered on indigenous liberation. At the beginning of the $21^{\text {st }}$ century, such insurrections created one of the most iconic social movements against neoliberalism and perhaps "the first great victory against globalization in Latin America" (Olivera \& Lewis, 2005 quoted from Spronk, 2006, p. 237). These radical movements, which paved the road for the election of the first indigenous president in Bolivia, Evo Morales, in 2006, were also part of the 'Pink Tide' or turn to the left by many Latin American governments (Sankey \& Munck, 2016). The elections of progressive and socialist leaders such as Hugo Chavez in Venezuela, Lula Da Silva in Brazil and Evo Morales in Bolivia signaled the possibility of radical change toward more just societies in the region. However, the Pink Tide is currently in a political crisis, and the election of far-right president Jair Bolsonaro in Brazil and the political crisis in Venezuela are quintessences of this crisis. As such, Evo Morales stands in a unique position, representing for many perhaps the last site of resistance and hope in the region. Certainly, Morales's stated agenda has been to transform the country into a post-neoliberal and postcolonial society through the 
redistribution of land, nationalization of industries and inclusive social policies (Webber, 2015). And a view into Bolivia's economic growth, poverty reduction, and social inclusion programs in the last decade shows remarkable achievements. According to the World Bank's country profile of Bolivia, economic growth has "averaged 4.9 percent between 2004 and $2014 \ldots$ moderate poverty reduced from 59 percent in 2005 to 39 percent in $2014 \ldots$ [and] the GINI index fell from 0.60 to 0.47 in the same period" (2015). A reduction on the external demand for natural gas has slowed this progress in recent years; nevertheless, Bolivia is still considered to be in economic progress (The World Bank, 2019).

Paradoxically, in pursuing economic growth, the Bolivian state has re-instated the international division of labor through an extractivist model of development known as social extractivism by Morales and his supporters and neo-extractivism by its critics. The term "neo" is used because unlike previous extractivist models, the state plays a more prominent role via nationalization, and/or an increase in rents and taxes, which allow the state to implement (social) redistributive policies, improve public infrastructure, and reduce public debt. Nevertheless, the core of extractivism, which is the commodification of nature, remains the same (Gudynas, 2011; Fabricant, 2015). Tensions have also emerged between indigenous communities and the self-proclaimed indigenist state due to the state's vested interest in expanding the extractivist frontier while ignoring its socioenvironmental effects (Veltmeyer, 2012, 2013). ${ }^{2}$

\footnotetext{
${ }^{2}$ Different authors such as Webber $(2011,2015,2016)$ and Cusicanqui (2015) use the word "indigenist" to describe the Bolivian state attempts to be an advocate of indigenous rights. "Indianness" refers to the social and cultural perceptions on what it means to be indigenous.
} 
Such paradoxes have been extensively researched, with much attention focused on the political economy of neo-extractivism, its socio-environmental impact and the reemergence of the nation-state as a key actor reshaping external and internal power relations (Bebbington, 2015; Webber 2016). In the case of Bolivia, although President Morales declared capitalism to be the key enemy of people, nature and Pachamama [Mother Earth] during the 2010 World People's Conference on Climate Change and the Rights of Mother Earth, evidence shows that capitalism is doing well in Bolivia (Webber, 2014). An archetypal example is the Bolivian Metallurgic and Mining Law 535 (MML 535) approved in 2014. Since mining operations require intensive water usage, this law gives to the mining industry the rights and privileges to use public water indiscriminately while at the same time it undermines the rights to water access of rural and indigenous communities in this area (Peralta, 2014, n.p). Rather than 21st century socialism, reconstituted neoliberalism is a more accurate term for Bolivia's current extractivist development model (Webber, 2011).

The literature on neo-extractivism also explores how it produces the same socioenvironmental effects as classical extractivism, and frequently exacerbates these effects (Gudynas, 2011; Svampa, 2015; Webber, 2014b). Water contamination, mining-induced displacement and resettlement become particularly salient considering that land distribution in Latin America is the most unequal in the world (Radcliffe, 2014). Neoextractivism has also generated a striking influx of profits, rents and taxes to rural and indigenous communities that has created new racialized class hierarchies such as petit indigenous capitalists who replicate the logic of extractive capital (Webber, 2016). A 
parallel line of research explores how the Bolivian state is consolidating its hegemony by declaring itself an indigenist state and by establishing indigeneity as the dominant national identity (Canessa, 2012, 2014). This state-led indigeneity is inclusive and encompasses the more traditional indigenous communities of rural areas, as well as traditional peasants, landless peasants in the lowlands, coca farmers, and indigenous immigrants in urban areas (Canessa, 2012, 2014; Cusicanqui, 2015). These last three groups also represent the political base of the government's party, Movimiento Al Socialismo [Movement Towards Socialism] or MAS.

Nevertheless, one central aspect still underexplored and undertheorized is how the tripartite relation between extractive capital, the state and civil society has affected indigenous women in the context of Latin America (Radcliffe, 2014). Although neoextractivism has become the principal development model in Latin America, most literature on extractive industries and gender comes from Africa and Asia, and these studies tend to use gender as an overarching category, which risks ignoring the experiences of indigenous women since they might have other barriers, such as language, to overcome (Deonandan \& Daughtery, 2016; Jenkins, 2015). There is also a body of literature on the Global South and extractivist industries that explores gender inequalities within the workplace (such as within mines for example) that is characterized by an uncritical perspective about the economic development brought by extractive industries (Lahiri Dutt, 2012). In relation to this, too much attention is given to production sites and their immediate surroundings, and not enough to remote places and people that are also affected by extractivist industries. 
Furthremore, the literature on indigenous and environmental movements in Latin America too often has a gender and intersectional blind-spot that reproduces the idea that indigenous women do not have political agency (Rousseau \& Morales, 2015; Deonandan \& Dougherty, 2016). Conversely, there is a romantic tendency to celebrate the inclusion of indigenous women as leaders within such movements without analyzing the triple burden that taking care of families, working within their communities and participating in resistance struggles represents (Canessa, 2012; Deonandan \& Dougherty, 2016).

These above-referenced studies only partially explain the extent to which the mutual interests between the state and extractive capital affect the lives of indigenous women, which is problematic but unsurprising. The historical development of capital accumulation in places like Bolivia has been racialized and gendered, constructing indigenous women as reserve players for capital accumulation (Webber, 2015; Cusicanqui, 2010). Yet, the lives and histories of indigenous women, and a critical analysis on how extractive capitalism relies on and exacerbates racist and patriarchal relations, remain absent. This is particularly relevant in Bolivia where, throughout its history, indigenous women have been ignored or represented as "the other" by an androcentric and neo-colonial state that perceives them as obstacles to progress and subjects to be modernized via development (Cusicanqui, 2012, 2014).

\section{Purpose}

The purposes of this study are threefold:

1. To analyze how the vested interests of the Bolivian state in expanding the 
extractivist frontier leads to a) a case of coincidental economic interests between the government and transnational capital where the former receives rents while the latter receives profits (Veltmeyer, 2013), and b) “accumulation by dispossession” (Harvey, 2003) that affect indigenous women within the context of indigenous territories in Bolivia.

2. To empirically explore how the Bolivian state that currently defines itself as indigenist and as the guardian of indigenous people's rights (Canessa, 2012) shapes racial, class, and gender intersections to harmonize them with the demands of neoextractivism.

3. To empirically analyze how indigenous women's unique positionality within processes of social reproduction and production, and within a system of interlocking race, class, and gender oppressions, creates specific subjugated knowledge that help them understand, articulate and organize against extractive capital and the state.

\section{Research questions}

Questions regarding neo-extractivism in Latin America have significantly focused on the macro-relationship between the state and extractive capital, and to a lesser extent on the state and indigenous communities. Figure 1 shows the research orientation of neoextractivism and the state. The dotted red line highlights the research focus of most studies on this issue. The thick red arrow represents the most explored line of research, which is the relationship between neo-extractivism and the state. 


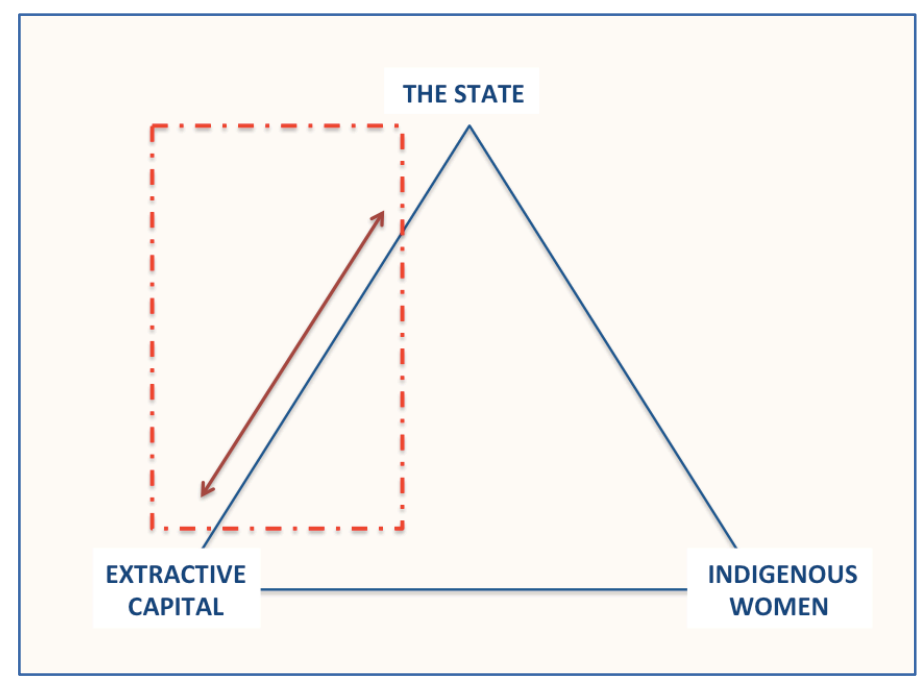

Figure 1. Research orientation on neo-extractivism and the state in Latin America

This study expands the analysis on the tripartite relationship between extractive capital, the state, and civil society by analyzing how the vested economic and political interests between the state and extractive capital affect indigenous women within the context of Bolivia. The following research questions guided this study and were the focus of the ethnographic fieldwork:

1. How does neo-extractivism affect the lives of indigenous women?

2. How does the state shape relations between neo-extractivism and indigenous women?

3. How do indigenous women organize to challenge the impact of state-led extractivism on their lives and their communities? 


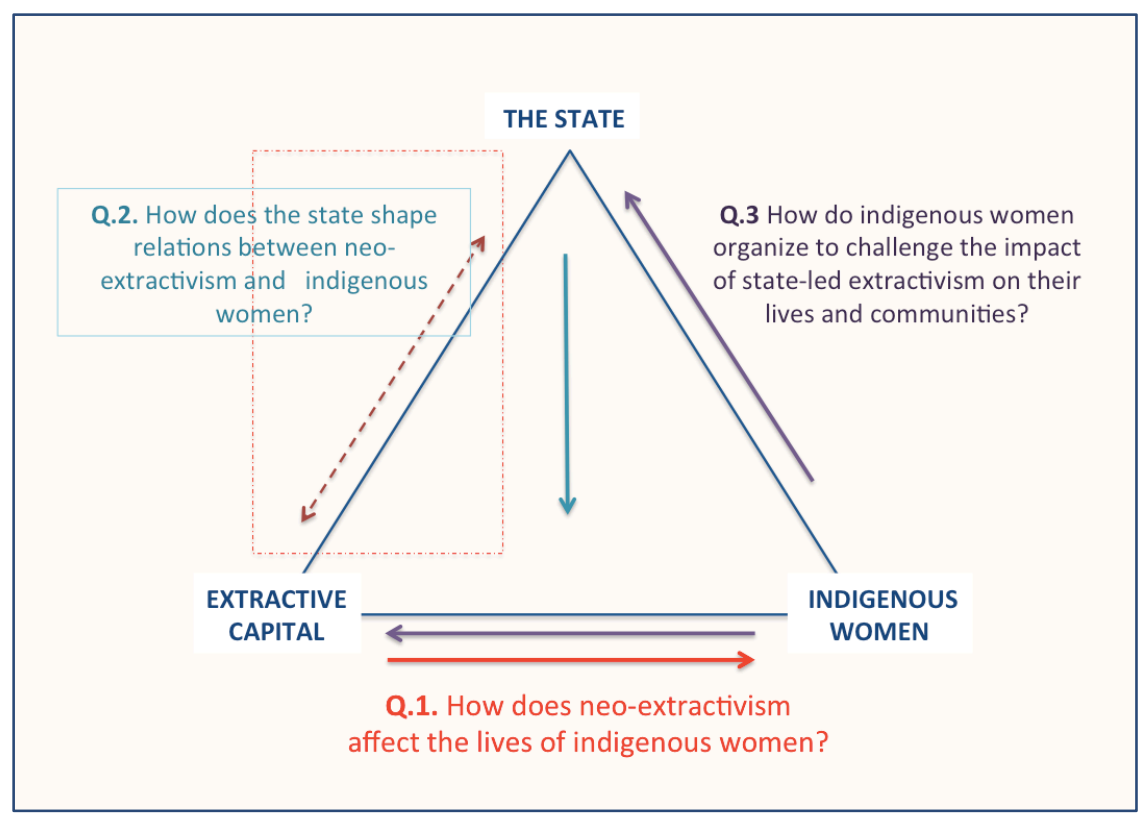

Figure 2. Research questions for this study

The research questions for this study and the relationships they explore are represented in Figure 2, which also shows the direction of each relationship. The arrow colors match the question they represent. For example the red arrow represents question 1 (Q1). The light blue arrow in the middle of the triangle represents question 2 (Q2) about the role of the Bolivian state, and the purple arrows represent question 3 (Q3).

\section{Background: A brief history of Bolivia}

With more than 40 percent of the population self-identified as indigenous, Bolivia is one of the most culturally diverse countries in Latin America, and is also one of the poorest and most unequal in the region (Webber, 2015). Moderate poverty affects 40 percent of the population, an extreme poverty affects 17 percent of them (mostly rural and indigenous communities) and income inequality remains high, with a GINI index fluctuating around 0.47, the same as the US, since 2011 (World Bank, 2019). Inequalities 
between urban and rural areas and between indigenous and non-indigenous people are striking. Bolivia has among the highest maternal mortality rates in the region, with 180 deaths for every 100,000 live births. Disaggregated data, however, shows that in indigenous and rural areas, the rate is as high as 600 deaths for every 100,000 live births (Bishnoi, 2011).

These inequalities reflect the exclusion of indigenous peoples in Bolivia and they are the result of deeply-rooted racial, ethnic and class oppressions constructed during colonialism and maintained through the creation of the nation state (Webber, 2014, 2014b, 2016). The history of indigenous people in Bolivia, however, does not start with colonialism and it is not defined by it. Bolivia, and more specifically the Andean region (where the city of Oruro is located) are home to millenary cultures and civilizations whose histories are defined by class struggle embedded in indigenous liberations.

Hylton and Thomson (2005) state that the Andes have had a discernible culture of indigenous rebellions. Like other authors, they argue that the social uprisings at the beginning of the $21^{\text {st }}$ century were inspired by collective memories of past anti-colonial struggles (Hylton \& Thomson, 2004, 2005; Webber, 2005; Cusiqanqui \& Geidel, 2010). These memories are manifested in the remembrance of indigenous leaders who embodied the character of indigenous liberation. The Katarista movement of the 1970s, described later in this section, which eventually would pave the road for the election of Evo Morales, was named after Julian Apaza, an indigenous Aymara leader who changed his name to Tupac Katari (in honor to Tomas Katari and Tupac Amaru, two indigenous leaders who led major uprisings during the 1500s). In 1781, Tupac Katari commanded a 
major insurrection of more than 40,000 Bolivians against colonial rule that besieged the city of La Paz for six months (Kennedy, 2009). His wife Bartolina Sisa and his sister, Gregoria Apaza also played major roles in this rebellion. ${ }^{3}$ Then there is Pablo Zarate Willca, known as el temible Willca, who in 1899 led one of the largest indigenous uprisings in the history of Bolivia. These are just few examples that illustrate a discernible culture of resistance.

In the formation of Bolivia as a nation, colonial ideologies and systems were reproduced by the state based on property rights, exclusion, and exploitation. The Spanish crown introduced the hacienda system, for example, to grant conquistadors arbitrary access to the land and to its people (a mechanism of ownership similar to feudalism). Whoever was living on the lands, and the lands themselves at the time of expropriation, became property of conquistadores, and the people who lived on these lands were forced to work for four to five days a week without payment (INRA, 2008). In 1500 A.D., the discovery of silver and gold in Bolivia made the city of Potosí the center of a commodity revolution and changed Bolivia's Andean agrarian economy into a mining-centered economy oriented towards natural resource exportation (Moore, 2010). The question of labor was so essential to the mining industry that in 1569 the new Spanish Viceroy, Francisco de Toledo, arrived in Potosí to understand how to better exploit the people and the resources. Three years after Toledo's arrival, the large-scale system of forced labor drafts known as Mitas was implemented (Moore, 2010). Indigenous men between 18 and 50 years old were forced to work in the mines under the

\footnotetext{
${ }^{3}$ Las Bartolinas, the National Confederation of Campesino, Indigenous, and Native Women of Bolivia is the largest indigenous women-led organization in Bolivia.
} 
mita system for at least a year in exchange for a minimal salary (and due to a mandatory tax system, more than half of salaries were taken away from the indigenous workers). This exploitation and oppression led to many indigenous insurrections, the most important being the Quechua-Aymara confederation led by Tupac Katari in Bolivia at the end of the $16^{\text {th }}$ century. These insurrections would become the ideological base for the formation of radical indigenous organizations in the 1970s and 1980s, which eventually would lead to the election of President Morales in 2006.

Independence in 1825 did little to change the dominant power structures (Arze \& Kruse, 2004). The latifundio system was introduced shortly after independence as a continuation of previous exclusionary and exploitative systems. Like feudalism, during the latifundio only a few landlords (mostly white European descendants) who also had the right to own their workers (the vast majority indigenous) owned lands, while indigenous people were not allowed to own any land (Foulkes \& Larrea, 2004). Latifundio aimed to replace the traditional communal land systems and push the indigenous population into debt peonage (Foulkes \& Larrea, 2004). Parallel to latifundio was La encomienda, a system where a community or group of indigenous groups were supposed to give tribute, either in money, work, or goods, to the encomendero (manager) in exchange for protection and Christianization (CEDIB, 2006).

Land reform became the central issue in the 1952 national revolution, which resulted in new progressive and inclusive polices such as the nationalization of mines, universal suffrage, and most importantly land redistribution among peasants (Arze \& Kruse, 2004). Despite this progress, the next 30 years were characterized by corruption, 
dictatorial rule, unmanageable debt, and a marked social exclusion of Bolivia's majority indigenous population (2004). Katarismo emerged in the 1970s as an indigenous movement in honor of Tupac Katari with decolonization as its political agenda, stating that in Bolivia and all of Latin America, the colonial legacy was endemic through racial and ethnic exclusion and class exploitation (Kennedy, 2009). In its early years, Katarismo faced internal fragmentation between its Marxist and indigenous wings. The former argued that class-consciousness was a priority over ethnic identity, where mestizaje (or mixed European and indigenous descent) seemed to be the most viable solution to "the Indian question" to build a new and more egalitarian nation ( \& Thomson, 2004). The latter disagreed, stating that ethnic identity was central for indigenous mobilizations. Eventually, Katarismo formed a coherent front under an indigenous, campesinx, and working class identity, which later would culminate in the election of Evo Morales as president (2004). The demands of Katarismo are encapsulated in the Tiwanaku manifesto, which states:

We Quechua and Aymara campesinxs, just like those other native cultures of the country, feel economically exploited and culturally and politically oppressed. In Bolivia there has not been an integration of cultures only a superposition and domination, maintaining us in the lowest and most exploited stratum in the social pyramid (Cortina, 2014, p. 172).

The 1980s marked the most orthodox implementations of neoliberal policies in the region (Klein, 2007) under President Victor Paz Estensoro, ironically known as the leader of the Bolivian National Revolution of 1952. Beginning in 1985, hyperinflation in Bolivia led to 
the implementation of the shock therapy by the creation of the Supreme Decree 21060 which contained more than 200 separate laws (Klein, 2007). One of these laws made strikes illegal, and another law shut down and/or privatized most mines, leaving 30,000 miners unemployed (CUNY, 2011). Following the loan conditionalities imposed by the World Bank and the International Monetary Fund (IMF), in 1993 the state privatized the most important state enterprises: the oil company, the national airline, phone and railroad companies and tin mines (Arze, \& Kruse, 2004). In 1997 the World Bank offered Bolivia $\$ 600$ million in debt relief, contingent on the assurance that it would privatize water provision in the city of Cochabamba (Arze, et al., 2013). These types of conditionalities are known as Structural Adjustment Policies (SAPs) that follow the premises of the Washington Consensus (Bockman, 2013). Massive protests in 2000, 2003 and 2005 against water privatization and in favor of the nationalization of Bolivia's natural gas paved the road for the election of Bolivia's first indigenous president, Evo Morales, in 2006.

\section{Evo Morales and el Movimiento Al Socialismo (MAS)}

The election of Evo Morales was remarkable on three fronts. First, Bolivia's historical development had always been rooted in racist and colonial ideologies. Therefore, Morales's election marked a new era. Second, the election of Morales was supported by an impressive, if not unique, united front consisting of a multiplicity of grass-roots organizations that were central in the creation of the new constitution. Third, Morales's election was part of a wave of left and progressive governments in Latin America known as the "Pink Tide", turn to the left, or socialism of the $21^{\text {st }}$ century. 
Following promises upon their election, the Pink Tide governments implemented redistributive and progressive policies such as nationalization, land distribution, and expansion or creation of welfare programs. Former president of Venezuela Hugo Chavez called these principles and actions 21st century socialism (Haiphong, 2014). It is important to note that the progressive policies in some Pink Tide countries indeed translated into economic growth, poverty and social inequality reduction. In Venezuela, for example, under President Chavez, unemployment dropped drastically, from 14.5 percent in 1991 to 7.8 percent in 2011 (Johnston \& Kozameh, 2013). In Ecuador, cash transfers reduced extreme poverty from 17 percent in 2006 to 8 percent in 2013 (World Bank, 2015). Bolivia also experienced similar progress with a reduction of social inequality (measured by the GINI index) from 0.60 in 2002 to 0.46 in 2013 (World Bank, 2015).

Nevertheless, the biggest contradiction among progressive governments in Latin America is that such economic growth has been the result of economic and development models based on the extraction of natural resources for export. While the discourse and some policies of so-called left-governments might seem progressive, and while the political representation within the state has became more diverse (more women, more indigenous people and workers in power), the underlying relationships of domination are still in place. In other words, the structural basis of the primary commodity export model of capitalist accumulation has not changed (Webber, 2016). For Bolivia, this means an indigenous government that continues the colonial division of labor of resource extraction and contamination of indigenous lands. It is these contradictions that have 
sparked a remarkable line of research.

Table 1. Extreme poverty and social inequality: 1999; 2012; 2018

\begin{tabular}{lcccccc}
\hline \hline \multicolumn{7}{c}{ Extreme poverty and Social inequality } \\
\hline \hline & $\mathbf{2 0 0 0}$ & $\mathbf{2 0 1 2}$ & $\mathbf{2 0 1 7 - 2 0 1 8 *}$ & $\mathbf{1 9 9 9}$ & $\mathbf{2 0 1 2}$ & $\mathbf{2 0 1 7 - 2 0 1 8}$ \\
Argentina & 8.4 & 1.7 & 7.1 & .53 & .47 & .40 \\
Bolivia & 38.8 & 18.7 & 24.7 & .58 & .46 & .44 \\
Brazil & 12.9 & 5.4 & - & .64 & .56 & - \\
Ecuador & 31.8 & 12.9 & 23.2 & .52 & .48 & .44 \\
Peru & 22.4 & 5.5 & 23.9 & .54 & .44 & .43 \\
Venezuela & 21.7 & 9.7 & - & .49 & .40 & - \\
\hline
\end{tabular}

Adapted from Boll, H. (2014). Hechos y Cifras: Extractivismo en America Latina. Fundacion Politica Verde; and The World Bank. (2019). World development indicators. *Represents poverty headcount ratio at $\$ 5.5$ a day.

\section{Fieldwork setting}

To explore these questions in depth, I carried out a multi-sited ethnographic study from October 2017 to June 2018 concerning mineral extraction and its effects on the department of Oruro, Bolivia. Figure 3 shows the location of this fieldwork study in Oruro, Bolivia. Fieldwork sites were near Lake Poopó (as show in this figure) where a significant number of mining concessions are located. In Figure 3, mining concessions are represented by the brown spots, which cross over significant sections of Oruro.

Since colonial times, mining has shaped Bolivia's history, economy and culture with the discovery of gold in the city of Potosí (considered the "Paris" of its time for all its wealth and development) and then the discovery of tin in Oruro in the 20th century (CEDIB, 2008). Although nowadays mining's contribution to Bolivia's GDP is only 5\%, it represents around $26 \%$ of total exports (INE, 2019). Like the well-known city of 
Potosí, Oruro's economy and culture has been historically mining-centered particularly since the discovery of tin, which made Simon Patiño el varon del estaño [the baron of tin] one of the world's wealthiest people at that time (Gareca, 2006). The tin mines also gave rise to one of the most radical workers' union in the region, the FSTMB (Federation of Miner Workers of Bolivia), which had a critical analysis of capitalism and demanded a workers' revolution (Gareca, 2006). In recent decades, however, Oruro's mining sector has experienced significant economic and political shifts, giving rise to three important actors within this sector: transnational companies, mining cooperatives, and newly nationalized mines (Perales, 2010). The Poopó province in Oruro, with a predominantly indigenous campesinx population and where I carried out fieldwork, has been heavily affected by mining contamination, particularly of water. Mining contamination has led to community-level organizing efforts, with a high participation of indigenous women and many times led by them (Perales, 2010). CORIDUP, a grassroots organization that represents more than 80 communities, epitomizes recent efforts to mitigate the effects of mining contamination. For these reasons, the protagonists of this ethnography are indigenous campesinx women in Oruro, Bolivia. ${ }^{4}$

To understand how these protagonists' lives are affected by neo-extractivism and how they resist and frame their efforts, the methodology for this qualitative study combines three main components: (1) 27 semi-structured interviews with community women leaders, key CORIDUP and community actors, representatives of CEPA (a local

\footnotetext{
${ }^{4}$ Indigenous communities and peoples in the department of Oruro, Bolivia refer to themselves as campesinxs [peasants], indigenous campesinx and campesinx indigenous. For this study I use indigenous campesinx as this was use more often by participants and also to highlight the ethnic and class position of participants. Other times I refer to participants, especially women, as indigenous only since they are not campesinxs, and vice-versa, sometimes only campesinxs to present as close as possible how participants identify themselves. Whenever I use direct quotes of participants' narratives, I use the words as they use them, usually campesino or campesina. The ' $\mathrm{x}$ ' in campesinx is used to represent gender inclusion.
} 
environmental NGO) and government officials; (2) participant observation; and (3) two focus groups.

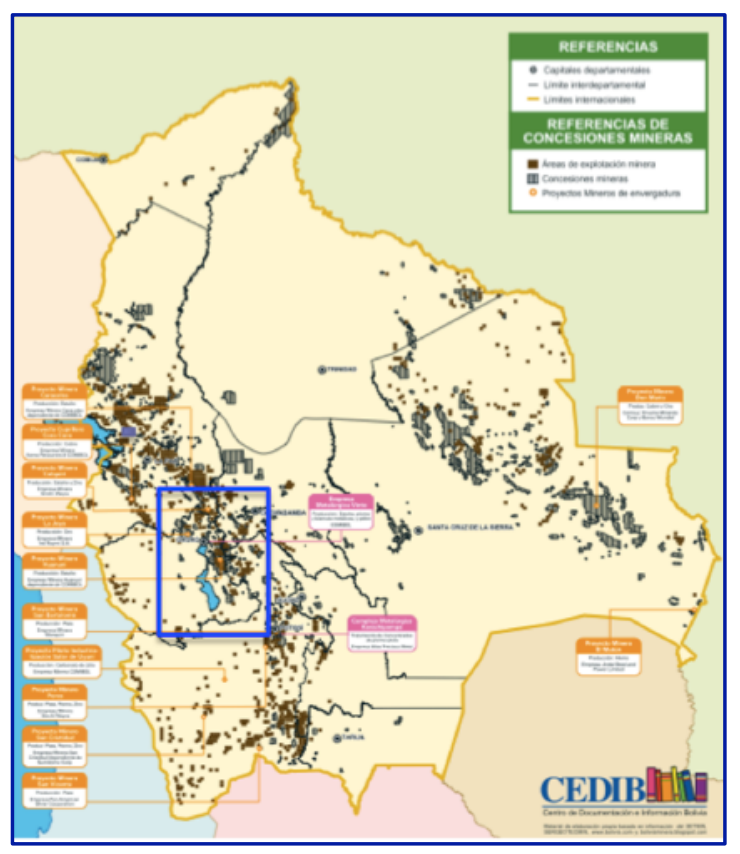

Figure 3. Mining concessions in Bolivia and geographical location of fieldwork for this study. Adapted from CEDIB (2012). Concesiones de explotation y exploracion minera. The blue square represents the fieldwork zone for this study

\section{Key findings}

Part II of this dissertation presents the findings of this study, where I describe in great detail a broad range of topics and issues that emerged during fieldwork. For this introduction, I briefly summarize the major findings that address the research questions of this study. First, this study shows that neo-extractivism produces the same or worse socio-environmental effects as classical extractivism, the most salient being the dispossession of indigenous peoples from their lands, principally through the contamination of waters, which is at the epicenter of all conflicts and the main reason for 
rural diasporas to urban towns near these communities. The contamination of waters also shows the racialized and gendered aspects of these dispossessions. These aspects, however, are often hidden since they occur in communities far away from points of production (mining centers). Social Reproduction Theory (SRT) brings a gendered and intersectional light to these dispossessions by revealing how the contamination of waters has worse effects on indigenous campesinx women since they play a central role in both subsistence production and social reproductive activities that require water.

Second, in order to consolidate its power, the Bolivian state is strategically deploying indigeneity to craft a national identity. This notion of the nation as indigenous is broad and inclusive. At the same time, however, it purposely conflates cultural groups with political ones, creating and exacerbating tensions between groups, such as those between indigenous miners and indigenous campesinxs. These tensions then weaken organizing community efforts. Simultaneously, this deployment allows the state to be the main decision maker over indigenous rights and over natural resources. Paradoxically, this ethnic inclusion also leads to class exclusions, particularly of historically marginalized groups such as indigenous campesinxs in the Andes who the state considers to be of little economic and political benefit to its developmentalist interests.

Third, the Bolivian state politicizes indigeneity in pursuit of power. In parallel, CORIDUP politicizes indigeneity in pursuit of justice, and unlike the state that uses indigeneity as an inclusive but rigid identity, CORIDUP and indigenous communities, particularly indigenous women, use indigeneity as a fluid and dual concept. This fluid indigeneity seeks to be connected to territories and one that is independent from them. 
Their indigeneity is rooted in soils, and also in the praxis of what it means to be indigenous. I call this rooted indigeneity, which has allowed indigenous campesinx communities to challenge divisions and build alliances along gender, ethnic and geographic locations to organize against extractive capitalism and the state. This rooted indigeneity has also allowed indigenous women to create solidarity networks among themselves and within and between communities, which then keep the social fabric of their communities.

Last, the sphere of social reproduction, where indigenous campesinxs women play a central role, represents a site of everyday resistances. The daily responsibilities of producing and reproducing social life and the unsubordinated practices of indigenous women leaders, embedded in Andean epistemes of reciprocity, duality and complementarity, represent genuine threats to and an alternative to capitalist, colonial, and patriarchal mandates.

\section{Contributions of this research}

The unique perspectives of marginalized peoples, located at the intersection of various oppressive systems, might offer a broader perspective to understand the features and consequences of capitalist societies. These unique perspectives might also be the ground for agency and collective action (Eisenstein, 1999, Hill Collins, 1990; Spivak, 1988; Mohanty, 2002). The analytical anchor of this study is the experiences of indigenous campesinx women in order to understand and question the character of political and economic transformations that are often analyzed separately from neo- 
colonial and patriarchal systems, giving the appearance that these systems are mutually exclusive, when they are not. By doing this, this study aims to make visible the nonmarket mechanisms that make capital accumulation within extractive capitalism possible. In combining five integrated and complementary theoretical and conceptual frameworks (structural mechanisms of the state (Block1987); world systems theory (Wallerstein, 1974); accumulation by dispossession (Harvey, 2003); political identities (Mamdani, 2001); and social reproduction (Battacharya, 2017),) this study bridges the analysis of macro political-economic forces with micro social realities of everyday life, showing how both are in continuous dialogue with each other, and where this relationship is a constant terrain of struggles. This is particularly urgent in regions like the Bolivian Andes (where the city of Oruro is located) that have historically been deemed useless for capital accumulation and irrelevant for the state's project of modernity, but now are invaded and subjected to capitalist and modernist logics in all aspects of life (Lopez \& Vertiz, 2015).

With this approach, this study challenges the uncritical analyses about the benefits of economic development that give instrumental visibility to indigenous women only as productive actors and labor commodities (Lahiri Dutt, 2012). It does this by examining indigenous campesinx women's oppression and exploitation by the "capitalist appropriation of the value produced through the gendered labor of social reproduction" (Glassman, 2006, p. 617). By analyzing the intersecting experiences of oppressions that indigenous campesinx women in Bolivia face, this study helps to address the current research gap in studies of gender and development that lack an intersectional frame and therefore risk ignoring the experiences of indigenous women (Deonandan \& Dougherty, 
2016; Cusicanqui, 2014).

This study also challenges the views that equate patriarchy with capital accumulation, and a questionable relationship between women and Pachamama (mother earth), which seems to rely on biological deterministic and essentialist perspectives (Lahirti-Dutt, 2011). Instead, this research uses Social Reproduction Theory (SRT) to understand the socio-historical development of the state and capital accumulation in Bolivia to show how both benefit from racialized, class-based and gendered hierarchies. Last, the exploration of indigeneity as a political identity closes a gap that ignores the central role of the state crafting rights based on essentialist, nationalistic and chauvinist ideologies of indigeneity. At the same time, this study shows how people politicize indigeneity in order to become political actors capable of defining indigeneity in their own terms, challenging the state's own crafting of indigeneity. By doing this, this research contributes to the existing literature in the sociology of development and globalization and the intersecting fields of ethnic exclusion, gender studies, indigenous studies and decolonial studies.

\section{Organization and structure of this dissertation}

This dissertation is organized in three main parts. Part I includes three chapters. Chapter One, the literature review, offers a comprehensive yet non-exhaustive overview of the main scholarly works and topics related to this dissertation, including extractivism, neo-extractivism, and the effects and impacts of neo-extractivism on indigenous communities, with an emphasis of its gendered effects. The literature review then focuses on political identities in Latin America. 
Chapter Two introduces the theoretical framework for this study. Since my goal is to first describe macro relations so that I explore how they interrelate and affect micro ones, I use five integrated and complementary theories to guide the formation of the research questions. I start this chapter by describing macro theories about the relationship between the state, capital and civil society: (1) the structural mechanisms of the capitalist state (Block, 1987), and (2) world systems theory and capital-state relations in peripheral countries (Wallerstein, 1974). Accumulation by dispossession (Harvey, 2003, 2005), presents a closer examination of how extractive capitalism operates in Bolivia. To address the research question about the state influences on indigenous communities, I describe in detail (4) Mahmood Mamdani's work on political identities (2001). Last, Bhattacharya's work on Social Reproduction Theory (2017) addresses the research question on why and how indigenous campesinx women organize to challenge extractive capitalism and the state.

Chapter Three describes in detail the data and methods used for this dissertation. As described in this introduction, this is a qualitative study that used a multi-sited ethnography consisting of semi-structure interviews, participant observation, and focus groups.

Part II presents the findings of this study organized as chapters Four, Five and Six, which correspond to each of the three research questions. Chapter Four discusses the findings on the effects of neo-extractivism on indigenous campesinx women and their communities. Chapter Five presents the findings on the Bolivian state and its cozy relationship with extractive capitalism, and chapter Six discusses the findings on the 
resistance by indigenous campesinx women and their communities. In Part II, I include little analysis or interpretation of the findings; rather I let the voices of participants speak, and present their opinions as they expressed them.

Part III presents the analysis and discussion for this study, Chapter Seven. This chapter describes my interpretations of the findings, guided by the theoretical framework. This section also highlights the limitations of the theoretical framework presented in chapter two and provides complementary theoretical interpretations guided by the findings. In other words, this chapter is a theoretical interpretation of findings based on a dialectical process where theory informs the findings and vice versa. Part III ends with the conclusions that highlight the most important themes that emerged throughout this dissertation, summarizing the key findings and their implications for theory, policy and other endeavors. The appendix includes all the documents used for fieldwork (interview guides, consent forms, etc.) as well as a brief analysis of the limitations of this study. 


\title{
PART I
}

\author{
CHAPTER ONE. LITERATURE REVIEW \\ CHAPTER TWO. THEORETICAL FRAMEWORK \\ CHAPTER THREE. FIELDWORK SETTING, DATA AND METHODS
}




\section{CHAPTER ONE}

\section{LITERATURE REVIEW}

The literature on neo-extractivism has generated unequivocal attention towards its socio-environmental effects and the contradictions it represents for progressive governments in Latin America (Webber, 2016). Exemplary works by Gudynas (2010), Veltmeyer (2012, 2013), Svampa (2015) and Acosta (2015), among many others, offer a comprehensive and critical analysis of the political economy of neo-extractivism and its relationship to the state. A systematic and empirical analysis of regional and crossnational comparisons that measures the degree to which neo-extractivism represents continuities and ruptures with neoliberalism, however, is still lacking (Burchardt, \& Dietz, 2014). Moreover, the socio-political impact of neo-extractivism has also received little attention.

The literature on indigeneity and the state points to the novel practice of including pro-indigenous ideologies and practices within national discourses, such as in the new constitutions of Ecuador and Bolivia (Gustafson, 2002). Nevertheless, as Cusicanqui argues, these considerations mask the reinforcement of statist centralism (2015). Moreover, attempts to define the inclusion of indigenous people in the nation as a new phenomenon ignore prior attempts of "indigenous inclusion in...state formation through labor, tribute, clientelism and centuries of violence" (quoted from Maybury-Lewis, 2003, p. 274). In Latin America, the state has historically shaped identities and group boundaries, particularly for minority and indigenous groups, through various ideologies and policies that aimed to homogenize its population (Van Cott, 1994). There is, 
therefore, a lack of a socio-historical analysis on how the state did and continues to deploy indigeneity. Albo (1994), for example, describes in detail the surprising alliance in the 1990s between the radical indigenous Katarista movement and the neoliberal party of former president Gonzalo Sanchez the Lozada, el gringo, who was the main proponent and advocate of neoliberal policies. ${ }^{5}$

Another body of literature examines gender inequalities within the mining workforce exclusively and this examines case studies around the world. This literature treats as gender progress and equity the fact that women are finally starting to work in the male-dominated mining industry and presents an uncritical perspective on the economic development brought by such industries (Lahiri Dutt, 2011) ${ }^{6}$ Last, there is a significant lacuna regarding neo-extractivism and its gendered impacts in Latin America (Deonandan \& Daugherty, 2016; Bebbington, 2015). Eutopia, a journal from the LatinAmerican Social Sciences Faculty (FLACSO), issued a 2014 volume pointing to the scant research on the experiences of women in rural Latin America given the global, structural and economic changes of the last 15 years (Radclliffe, 2014).

To address these research gaps, the following literature review is a non-exhaustive overview of empirical studies that illustrate the state-capital-civil society relations in three areas: a) the articulation of neo-extractivism and the state, b) the impact of neo-

\footnotetext{
${ }^{5}$ The nickname el gringo is in reference to Sanches de Lozada's Anglo-American accent since he grew up in the US. During his second presidential term, the water war protests forced el gringo to resign and to escape into exile to the US where he currently lives.

${ }^{6}$ It is also important to highlight that a significant number of studies and reports are not peer-reviewed. The World Bank, the International Finance Corporation (IFC), The Minerals Council of Australia and the InterAmerican Development Bank for example have produced many studies addressing gender inequality and gender inclusion within mining industries' impact assessments as smart economics (Partmenter, 2008, p. 2).These studies, while rightly supporting gender inclusion within mining industries, often ignore the negative impacts that mining produce in communities. At the same time, since the literature in this topic is scant, these studies also offer important insights and context about gender and mining industries.
} 
extractivism on indigenous communities, particularly indigenous women and c) the state and political identities. The regional focus of this literature review is Latin America, particularly Bolivia as a unique case study of a self-proclaimed indigenist state.

Nevertheless, due to the aforementioned research gaps, this literature review also presents case studies across different regions, time periods and types of extraction (classical extractivism, neo-extractivism and Artisanal and Small Mining, or ASM).

\subsection{Classical extractivism}

Extractivism has lengthy colonial roots in the socio-historical development of Latin America, where its basic goals and mode of accumulation have remained the same, even after independence (Acosta, 2013). Acosta defines extractivism as the removal of large quantities of unprocessed or minimally processed natural resources for export (2013). During colonial times, extractivism depended predominantly on human and animal labor, with minor use of technologies (Gudynas, 2011). Between the 18th and the 20th centuries, the economic and social transformation of the time included new technologies, particularly heavy machinery such as the first internal combustion engines that facilitated resource extraction (2011). From 1940 to 1960, the economic stagnation of independent nations in Latin America, despite vast natural resources, was attributed to a shortage of investable capital (Gudynas, 2011). To attract foreign capital, a renew emphasis on extractivism aimed to improve and benefit peripheral countries by creating jobs, developing local infrastructure, and generating revenues to be used for social policies (2011). Instead, core nations that produced the manufactured goods were the only ones that benefited from economic growth and surplus transfer at the expense of 
the peripheral countries (Veltmeyer, 2012). Underdevelopment in Latin America resulted from the same processes that produced development in core countries (Peet \& Hartwick, 2009).

In the 1960s, the Keynesian developmental state arose with state-led industrialization, where the role of the state was expanded towards the domestic market into a new development strategy based on the "exploitation of labor rather than exploitation of resources" (Veltmeyer, 2012, p. 81). In peripheral Latin American economies, this model was superimposed to export-based industries. The export of natural resources and the dependency it created on global markets did not translate into economic growth. The nations that became dependent on extractivist modes faced slow economic growth, weak democratic processes and more political instability, such as civil wars, than resource-poor states (Ross, 2001). Higher economic dependency on extraction translated into lower HDI, higher levels of poverty and income inequality (Ross, 2011).

\section{2. Neo-extractivism}

Since 2000 , a boom in demand for primary commodities, particularly from China, has led to the emergence of a new extractivist model in Latin America. According to the World Bank, while mining exploration grew 90 percent worldwide between 1990 and 1997, in Latin America it grew 400 percent (Li, 2015). Data from the Economic Commission for Latin America and the Caribbean show that the mining sector's foreign investment doubled since 2007 (Veltmeyer, 2012). In 2010, Mexico was fourth place worldwide for investments related to mining explorations (Mining in the Americas, 
2013). This new wave of extractivist activities, known as social or progressive extractivism by its supporters, and as neo-extractivism by its critics, refers to the national development strategies based on economic, social and political policies adopted by left and left-centered governments in Latin America (Argentina, Brazil, Bolivia, Ecuador and Venezuela) known as the Pink Tide over the last decade and a half (Sankey \& Munck, 2016). Neo-extractivism relies principally on Foreign Direct Investment (FDI) for the extraction of natural resources as primary commodities (Burchardt \& Dietz, 2014). It also changes contractual arrangements with transnational investors, raises the royalties and/or taxes payable to the state, and allows the state to redistribute rents through social policies (Veltmeyer,2012, 2013). Nevertheless, what makes neo-extractivism new is the more prominent and central role of the state via nationalization and/or direct resource management or through an increase in rents and taxes which in turn are redistributed through social policies (Gudynas, 2011; Burchardt \& Dietz, 2014). ${ }^{7}$

Those who support neo-extractivism point to the impressive economic improvement that the Pink Tide has delivered. Bolivia, for example, has experienced an average economic growth of 4.9 percent since 2004 , and a decline in moderate poverty from 63 to 45 percent between 2002 and 2012 (World Bank, country profile, 2015). Similarly, Ecuador has experienced an average GDP growth of 4.3 percent since 2006, a reduction in poverty from 37.6 to 22.5 percent as well as an improvement in the GINI index from .54 to .47 (World Bank, country profile, 2016). Supporters argue that critics ignore these economic improvements and do not consider the complexities and the time

\footnotetext{
${ }^{7}$ Neo-Extractivism includes activities in farming, forestry and even fishing. For the purpose of this paper, the conceptual and analytical definition of neo-extractivism focuses primarily on extraction of minerals, and to a lesser extent to natural gas.
} 
needed to transform an economic mode of production. They claim that critics ignore the needs and realities of the very people they aim to support (Fitz, 2014). Bolivian Vice president Alvaro Garcia Linera contends that instead of thinking of neo-extractivism as an end in itself, critics should interpret this as a point of departure to eventually overcome capitalism (Garcia Linera, 2013).

On the other hand, critics argue that although Latin America has experienced significant political changes, the extractive sector maintains its dominance. Neoextractivism is one of the pillars of the current development model across the region, where supporters highlight its economic benefits while ignoring its well-documented socio-environmental consequences (Robinson, 2011; Gudynas, 2011). Critics also point to the limited or non-existent transformation of unequal power relations between capitalist interests and communities under Pink Tide governments (Webber, 2014). These governments have also de-radicalized dissent and have co-opted social movements (Robinson, 2011). Critics argue that resource extraction perpetuates economic dependency on raw material exports. Thus, this neo-extractivist model of development should be understood by analyzing the history in Latin America of overexploitation of natural resources, which has created "resource curse" (Gudynas, 2011; Veltmeyer, 2012, 2013).

Because of diverse political orientations (left, centrist, right) and diverse policy implementations, scholars have placed Latin American governments in different categories. Veltmeyer for example, refers to Colombia and Mexico as neoliberal, Argentina, Brazil, and Chile as third way post-neoliberal, and Bolivia, Ecuador and 
Venezuela as "radical populist and resource nationalist, or proto-socialists" (2013, p. 83).

Lopez \& Vertiz classify Latin American countries according to their national development models as well as their policies and rhetoric towards US imperialism: neoliberal with strong ties to the US (Mexico, Chile, Peru, Colombia, Paraguay, and most countries in Central America); National-populists or neo-developmentalists (Argentina, Brazil, and Uruguay) and anti-neoliberal and anti-imperialistic (Bolivia, Ecuador and Venezuela) (2015). Nevertheless, independently of political orientation or type of national development projects, all Latin American governments have relied on the expansion of the extractivist frontier as a mechanism for development and economic growth.

What is happening in Latin America represents a case of coincidental economic interests between governments and transnational companies. The former receives rents; the latter receives profits (Veltmeyer, 2012, 2013). Within the context of political economy, neo-extractivism reflects and supports the need of states to negotiate and strike better deals with agents of global capital and share the economic benefits from the plunder of resources (Veltmeyer, 2012). The state therefore uses royalty payments and taxes to generate "resource rents", which following convention, I refer as state rents (Burchardt \& Dietz, 2014). Rent is a form of surplus value and for neo-extractivism it relates to the " resource curse" where many authors argue that rent-base economies have also political and social dimensions (2014). Mahdavy (1970) for example refers to the 
surge of authoritarian patterns, corruption, patronage and ineffective and inefficient structures in rentier states. ${ }^{8}$

In other words, the state has made a deal with global capitalist agents due to a coincidence of economic interests where both the state and global capital, have found common benefits (Veltmeyer, 2012). Even within a context of global market volatility and financial crisis, Latin America has shown that it will continue relying on primary resource extraction (Svampa, 2015). The consolidation of neo-extractivism as the principal development model in Latin America points to "the commodities consensus" which marks the beginning of a new economic and political era supported by the international demand for raw materials (Svampa, 2012). The word consensus suggests that independently of regime type, there is a tacit regional agreement that development in Latin America must aim for "economic growth, productivity and modernization" (Svampa, 2015, p. 122). Under this logic, the demand for primary resources will allow the region to eventually get closer to industrialized countries (Svampa, 2012). Latin American countries therefore, are reassuming their role as exporters of primary products in a neo-colonial turn of the state (Svampa, 2012; Cusicanqui, 2014). This regional

\footnotetext{
${ }^{8}$ The concept of rentier state was developed in the context of the Middle East and North Africa with authoritarian governments. In Latin America, however, regimes are democratic and therefore increase authoritarian rule, a feature of rentier states does not apply, but other features, such as corruption and patronage do (Burchant \& Dietz, 2014).
} 
model of development produces two key areas of tensions: laws regulating access to natural resources, and foreign direct investment (FDI). ${ }^{9}$

\subsubsection{Laws over land and natural resources}

Burchardt and Dietz (2014) argue that to understand neo-extractivism, it is crucial to identify who has the power to assert their interests, who the decision makers are, and who is carrying the risks. A considerable number of laws and decrees regarding the distribution of rights over natural resources created in the last decade show that the state, independently of regime type (left, right, center), perpetuates an asymmetrical power relation between the capitalist sector and local communities (Burchardt \& Dietz 2014). The state in left regimes does not support neoliberal orthodoxy. For example nationalization of industries is supported, and the state presents itself as a neutral actor. Nevertheless, it operates in the interest of the ruling class, and under these regimes, neoextractivism has deepened (Webber, 2011; Gudynas, 2011). The mining sector under Brazilian presidents Lula Da Silva and Rousseff doubled aluminum production and tripled the production of copper. In 2009, Ecuadorian president Rafael Correa approved a new mining law that gives international companies more and better access to conduct extraction activities. This same law violates the constitutional right of indigenous people

\footnotetext{
${ }^{9}$ Nationalization is another key area that reflects the contradictions of the Pink Tide Governments because it has been a central promise of these governments. Nevertheless, there is lack of cross-comparative studies to measure the extend of this contradiction. Yet it is worth mentioning that nationalization under Bolivian president Evo Morales has been modest at best. Contrary to expectations of state monopoly or the expropriation of private corporations, nationalization in Bolivia reflects a state management of rents and taxes while private companies accumulate capital (Webber, 2015). The state-owned mining sector for example is minimal, including only nine percent of the Bolivian mining labor force and most Bolivian mines today are still operated and owned by transnational companies (Webber, 2014, 2011). In Argentina, the nationalization of YPF (Fiscal oilfields) enterprise in 2012 was accompanied by a policy to increase the extraction of non-conventional gas and oil reserves (shales) (Seone, 2012).
} 
to prior and free consultation that is stipulated by the International Labor Organization (ILO) convention (Safransky \& Woldford, 2011).

During the 2010 World People's Conference on Climate Change and the Rights of Mother Earth in Cochabamba, President Evo Morales declared capitalism to be the key enemy of nature: "We have two paths: either capitalism dies or Mother Earth dies" (quoted in Webber, 2010). This bold rhetoric notwithstanding, extractive capitalism is doing well in Bolivia (Webber, 2014). In 2015, the Bolivian government issued a series of decrees that opened national parks and other protected areas where many indigenous communities reside, and made these lands available for oil and gas exploration (Stirling, 2015). These decrees also weaken the political bargaining power of indigenous communities living in these areas because the exploration, identification, and exploitation of new fields need a change of access to rights (Burchardt \& Dietz, 2014). These decrees give more power to the state as a decision maker in such negotiations.

Similar patterns are found across the region. It is estimated that 23 percent of Mexico's national territory has been made available for extractive capital exploration (Veltmeyer, 2013). In Colombia, the government has conceded to extractive capitalists approximately 267 land titles and mining concessions without previous consultation with local communities, and in the Cauca department alone, 60 percent of its territory has been made available for large scale mining (Rojas, C. et al, 2015). In 2016, Venezuelan president Nicolas Maduro signed a presidential decree called Arco Minero del Orinoco which opens up "nearly 112,000 square kilometers [or] 12 percent of the country’s territory to the large-scale mining of gold, diamonds, coltan, iron and other minerals" 
(Lalander, 2016, p. 14).

Perhaps the epitome of the articulation of interests between the state and extractive capital is the Amazonian Yasuni National Park in Ecuador, extremely rich in biodiversity and unexplored oil (Lalander, 2016). In 2007 President Rafael Correa proposed the Yasuni ITT project which would suspend oil explorations in the region in exchange for international monetary compensation, which did not materialize. By 2016, Correa's government had started the construction of " 276 planned wells, ten drilling platforms, and multiple related pipelines and production facilities" (Amazon Watch, 2016). There are also two new concessions in the south border of the park where oil lease actions are planned (2016).

\subsubsection{Foreign Direct Investment (FDI)}

FDI is "the ownership by a foreign party of 10 percent or more of an enterprise, enough to give it a lasting interest" (Higginbottom, 2013, p. 3). According to the Economic Commission for Latin America and the Caribbean (ECLAC, 2015), FDI in the region for 2014 was nearly \$US 158.803 billion, which shows the significance and growing presence of FDI in Latin American and Caribbean economies. In a crosscomparative analysis, Higginbottom shows that "U.S. and European capital today own three times more of Latin America than they did just 15 years ago" (2013, p. 200). Canada's FDI in mineral exploration and mining has also reached a record high in 2008 with \$128.3 billion (Veltmeyer, 2013). Between 2002 and 2010, FDI in the region has increased by 172 percent, "reaching levels 66 percent higher than those of the neoliberal era (1990-2001)" (Lopez \& Vertiz, 2015, p. 156). Although the increase in FDI is a 
regional trend, not all countries have experienced the same degree of FDI penetration. Chile, for example, has maintained a steady FDI flow over the past decade while Bolivia "has reduced its dependence on FDI, although it is still at a high level" (Higginbottom, 2013, p. 194).

There is also an increase of FDI towards the export of raw commodities, particularly minerals, with a 400 percent regional increase. There is also an increase of FDI in agro-industrial products, with an 100 percent increase in the last decade and a half (Lopez, 2013). In Colombia, FDI for mining extraction increased 500 percent between 2002 and 2009, and in Argentina mining exploration increased by 300 percent (Seoane, 2012). Similarly, mining exports from MERCOSUR countries (Argentina, Bolivia, Brazil, Chile, Paraguay and Uruguay) more than doubled between 2004 and 2008, from $\$ 20$ to $\$ 58$ million dollars (2012). In Venezuela, Ecuador and Bolivia, primary products for export during 2010 represented 90 percent or more of each country's total exports. Under Brazilian president Lula Da Silva, primary products for export in 2010 represented 60 percent of Brazil's total exports (Gudynas, 2011). Moreover, 65 percent of FDI in the region had the goal of buying regional corporations (Lopez, 2013). As Svampa (2015) argues, this points to the re-primarization and trasnationalization of Latin American economies, where the logic of national production of the countries “...[is subordinated] to the needs of global capital accumulation" (Lopez, 2013, p. 157).

\subsection{Neo-extractivism and indigenous communities}

\subsubsection{Socio-environmental effects}


The social and environmental impacts of neo-extractivism are the same as classical extractivism, and the expansion of the extractivist frontier in Latin America is predominantly occurring on indigenous lands (Gudynas, 2011). Mining-induced displacement and resettlement is defined as the "loss of physical and non-physical spaces, which includes homes, communities, productive land, income-earning assets, resources, cultural sites, cultural identity, and mutual help mechanisms" (Bambas et al., n.d., p. 6). Displacement and resettlement, however, are not exclusive to mining, but are necessary mechanisms for the extraction of agricultural commodities and fossil fuels as well (Veltmeyer, 2012). This leads to the territorial dispossession and displacement of (very often entire) peasants and indigenous communities, which is often the principal way that large-scale mining affects indigenous communities (Jenkins, 2014). This becomes particularly salient in Latin America, where extremely unequal land distribution relates to indigeneity, rurality and poverty (Radcliffe, 2014). Moreover, displacements may have a distinctly negative impact on indigenous women since they represent two thirds of the agricultural labor force in rural areas (Calla, 2006).

Water, a central element in the social and environmental sphere, is located at the center of contestations against neo-extractivism. Perreault argues that water dispossession for capital accumulation takes many forms (2013). One form is the dispossession of collective rights and access to them. Extractivist activities, fossil fuels, minerals and crops are water-intensive, and therefore rely heavily on water availability and accessibility, particularly for the semi-arid regions of Bolivia (Perreault, 2012). The Huanuni mine in Bolivia, for example, consumes 28 million liters of water per day. Yet it 
is estimated that 36 percent of the Huanuni valley residents have no access to fresh water, which also reflects major contamination problems (Perrault 2013). Mining waste, which accumulates over the years, has leaked and caused serious environmental destruction when rock drainage occurred. Rock drainage pollutes water reservoirs, rivers and lakes. It makes water not only unsuitable for drinking but also unsuitable for agriculture (Acosta, 2013). In the Allkumarka community located downstream from the Huanuni town and the Huanuni mine, agricultural production has decreased because of the salinization of wells, recurrent droughts and lack of investments in agricultural infrastructure (2013). In 2016, the Poopó, Bolivian second largest lake and an important economic and cultural site for the Urus indigenous communities, dried out. Experts point to mining contamination and water diversion for mining as main reasons (Campanini, 2014). Using territoriality as a central concept for analysis, Bebbington shows how on one hand, the local communities in Bolivia's lowlands have a long history of unequal relations with the central state and hydrocarbon companies (2009). On the other hand, the increased revenue from hydrocarbon extraction has created new inequalities and conflicts between and within geographical populations. In 1900, the Weenhayek, one of the three indigenous communities located in el Gran Chaco region, obtained formal state recognition as TCOs (Indigenous Territories of Collective Origin) and elected ORCAWETA (Organization of the Weenhayek Captaincy) as their community representative for negotiations with energy firms. Multinational companies such as British Gas Bolivia offered direct payments to ORCAWETA as a main mechanism to dominate negotiations. Direct payments to indigenous leaders weakened the capacity for 
collective action within communities. ORCAWETA also used this mechanism to maintain its power by redistributing payments among its members, which led to internal tensions between leaders, and community members who feel betrayed by both community leaders and companies (Bebbington, 2009).

\subsubsection{Class relations}

Despite the breadth of research on neo-extractivism, an examination of its class content and its socio-political forms is still missing (Webber, 2015). Focusing on Bolivia as a case study, Webber describes Evo Morales's presidency as an alliance between agroindustrial capitalists of the lowlands, capitalists from the mining and hydrocarbon sector, and a new "indigenous bourgeois layer in cooperative mining, commercial trading, contraband, and narcotics" (2015, p.1957). Historically, racist ideologies were the modus operandi in Bolivia. Nevertheless, since the ruling class was unable to rule within explicit racist ideologies in the late 1990s, it instead decided to share political power with the emergent petty indigenous capitalists who continue to legitimize the logic of capitalism (2015). These petty indigenous capitalists are the product of large-scale extractive industries and petty commodity production, and the continuing exploitation of waged labor in mining, among other sectors.

Mining cooperatives are an example. They portray themselves as collective and egalitarian. However, mining cooperatives are extremely hierarchical, and exploitative, closely resembling large private enterprises. At the top is a socio, a bourgeoisie mestizo cooperative member, who hires informal workers (mostly indigenous) who receive no benefits from cooperative membership (no life insurance or decision-making power) 
and are extremely exploited, receiving lower wages than the minimum wage (Martson, 2013). The government, however, continues to support the growth of mining cooperatives, turning a blind eye to the cooperative's internal structures of exploitation (2013). The emerging importance of mining cooperatives as central actors in resource regimes in Bolivia and elsewhere shows that the mining economy is a hegemony based and maintained "by the close historical relationship between mining cooperatives and the state" (Marston \& Perreault, 2016, p. 1).

\subsection{Neo-extractivism and indigenous women}

\subsubsection{Artisanal and Small Mining (ASM)}

A body of literature analyzes women's work within mining extraction, particularly the gendered nature of mining work and how identities are negotiated in spaces that are male dominated (Lucas \& Steimel, 2009). Lahiri-Dutt and Macintyre provide perhaps the most comprehensive overview on this topic in Women Miners in Developing Countries: Pit Women and Others (2006). Special attention is given to women in Artisanal and Small Mining (ASM). ${ }^{10}$ It is estimated that around the world women represent one third of workers in this sector, yet androcentric constructions of miners as men hide women's labor within this industry (Jenkins, 2014, Lahiri-Dutt, 2011).

\footnotetext{
${ }^{10}$ ASM is defined as "extraction that is manual and very labor-intensive, using only picks, shovels and basins or somewhat mechanized, using heavy machinery on a small scale...by individuals, families or cooperatives" (Dorner, U. et al, 2010, p.1). The salient aspect of ASM is that it is informal (and sometimes illegal) and its activities take place within "formal mining concessions of large-scale mining" (Miningfacts, n.d). 
In her work about women miners in Bolivia, Van Hoecke shows that there are approximately 1,500 Bolivian women working as miners who are affiliated to 65 mine cooperatives (2006). Women miners are called Palliris, a Quechua word meaning widow and/or abandoned since palliris are predominantly the widows of male miners (2006). The gendered division of labor places most palliris in ASM or working outside of mines (receiving lower wages) while men work inside large-scale mining receiving higher wages. This gendered division of labor also interconnects with cultural beliefs since male miners believe women within mines bring bad luck (2006).

Because ASM is informal and sometimes illegal, women miners work in precarious conditions, with little or no job regulations and no benefits (Lahiri Dutt, 2011). In rural contexts, access to documentation is complicated, therefore most palliris do not receive any work benefits or pensions as widows (Van Hoecke, 2006). Their partners might have failed to ask for social contributions due to entrenched bureaucracy or their partners might have worked under informal contracts as well. Palliris continue this exploitation by entering the informal sector and receiving no labor protection (2006). There are however, contradictory findings. Based on a qualitative study in the Chorolque mining cooperative in Potosí Bolivia, Chambilla Mamani argues that palliris prefer to work in ASM (2011). Although ASM might pay less, it gives palliris more autonomy as they can choose when to work. In large-scale mining, women must work in teams comprised mostly of men who usually get a higher salary and they must follow a strict schedule, which conflicts with household work (2011). 


\subsubsection{Large scale mining}

In Latin America, the expansion of the mining industry has contributed to the increased feminization of poverty due to the gendered division of mining labor (Deonandan \& Daughtery, 2016). In Colombia, women represented only 19 percent of the mining labor force, even though mining has expanded significantly since 2006 (Center for Research and Popular Education, 2013). Two studies from the Philippines and Papua New Guinea mention that women do benefit from large-scale mining by being hired in administrative, managerial and sometimes leadership positions, which allows women to obtain higher incomes and greater job security (Jenkins, 2014, p. 332). Nevertheless, practices like fly-in fly-out (FIFO) limit women's possibilities since they demand schedule flexibility and availability to take on overtime in isolated locations, which is counterproductive for mothers and family caregivers (Lahiri-Dutt, 2011).

Chambilla Mamani (2011), on the other hand, criticizes the artificial division between ASM and large-scale mining presented by studies about women miners. Her empirical research shows that women miners do not work exclusively in ASM or largescale mining, but rather they work in both sectors depending on market demands and weather conditions (2011). The low temperatures during winter in Bolivia make outside work in ASM unbearable. Therefore, women miners choose to work inside mines. Chambilla Mamani calls this itinerant work since it happens in spaces considered both masculine by being inside mines, and feminine by being in ASM (2011). Furthermore, unlike most literature on mining and gender that highlights tensions between male and female miners, Chambilla Mamani explains that although women miners do face tensions 
within their work, they also build social relations of fellowship within and around the cooperatives. While this study sample is not representative, it offers a valuable nuanced perspective on the experience of women miners.

\subsubsection{Health and social impacts}

Macdonald and Rowland (2002) point to the gendered impact of mining and extractive industries on women's health. Women suffer higher rates of HIV and STD infections and the precarious health provisions in rural settings aggravate such impacts (2002). The detrimental environmental effects of mining, such as mercury pollution, affect women's reproductive roles (Hinton et al., 2003). The increased violence against women related to the arrival of male immigrants, and the rise of alcohol consumption and domestic violence, are well known effects of large-scale mining (Perks, 2011). Women in mining communities also experience social and economic changes since they lose their status as subsistence and small-scale farmers, therefore becoming more dependent upon men (Jenkins, 2014).

Studies by Ward and Strongman (2011) and O'Faircheallaigh (2013) show that in Peru and Western Australia, the consultation process led by mining companies is gendered by including mostly men, excluding women, and undermining women's roles as decision makers. Corporations and compensatory public policies give less priority to projects proposed by women because these projects include health, education, nutrition, smaller-scale infrastructure, and capacity building (Ward \& Strongman, 2011). In contrast, greater priority is given to projects proposed by men, usually miners themselves, since they have narrow demands such as higher wages and the generation of more 
cash income for larger-scale infrastructure (2011). In Australia, Papua New Guinea, Indonesia, the Philippines and India, indigenous women are excluded from both the negotiations about mining development projects and from receiving benefits. This means that women are involved neither as a party in the negotiation process nor as beneficiaries of it. O'Faircheallaigh, however, challenges these findings by arguing that negotiation is narrowly described as face-to-face discussions at one point in time, which often ignores the ongoing process of defining an agenda (2013b). In the Comaclo bauxite mining operation at Weipa in Queensland for example, Australian indigenous women are important actors setting the negotiation agenda before consultation, which they might or might not participate in (2013b). The national legal context of recognition of indigenous rights is also fundamental, especially for the case of Australia, which has achieved significant recognition of indigenous land rights (2013b).

\subsubsection{Intersectionalities}

The literature on intersectionalities, particularly between gender and ethnicity within mining extraction, is scant. Sinha and Smith offer two historical analyses from India and Japan that highlight the limitations of examining mining industries without an intersectional framework (2006). Sinha shows how the nationalization of coalmines in post-colonial India had a gendered effect by decreasing female labor in the mines, especially affecting indigenous women (2006). In the Chotangapur plateau of India, the mechanization of mining as well as the ban on women in underground mines forced Adivasi (indigenous) women to work as unskilled and informal workers in the agricultural, manufacturing and construction sectors (2006). Sinha argues that this 
ban increased sexual exploitation and commercial sex since Adivasi women experienced more economic hardship and fewer opportunities to work. The mechanical development of mining created migration to towns, which disintegrated traditional family structures and made them more individualistic (2006). Adivasi women were also more vulnerable to culture and identity loss and discriminatory interactions with caste systems. Sinha concludes that industrial mining and capital enterprises, with the mechanization of mines and the ban on women in underground work, created an opportunity for cheap casual labor that was filled by Adivasi women. As cheap and informal labor, Adivasi women experienced harsher living and work conditions, as well as cultural disconnections (2006, p. 105).

Through a socio-historical analysis of Korean women in coalmines in Japan, Smith (2006) debunks generalizations about the gendered impact of mining by using an intersectional lens. In the Chikuko coalmine in Japan (one of the most important mines in modern Japanese history), better job opportunities were available for Japanese women who became sakiyama, or supervisors (2006). This, however, was not the case for Korean women since "there is no record of even a single Korean women becoming a sakiyama" (2006, p. 117). Korean women who did not work as miners were forcibly sent to brothels created for Korean and Japanese men near coalmines (2006). Analysis of these places is framed in terms of Japanese exploitation of other nations. Smith, however, argues that this was also exploitation of colonized Korean women by both colonized and colonizer men within Japanese imperialism. Smith concludes that the experience of Korean women around Japanese mines shows that analysis about life and work around mining 
communities should not be explored "from the standpoint of either gender and ethnicity alone" (2006, p. 127).

\subsubsection{Indigenous women's responses to neo-extractivism}

The scant research on indigenous women and neo-extractivism in Latin America tends to focus exclusively on oppression, while giving little to no attention to how women exercise their own agency (Deonandan \& Dougherty, 2016; Macdonald \& Rowland, 2002; Lahiri Dutt, 2011; O'Faircheallaigh, 2012). This is explained in part by Chandra Mohanty's criticism of feminist writings and their characterization of Third World women as singular, monolithic subjects, passive victims of global processes (2002). The literature on indigenous and environmental movements too often has an intersectional blind spot that reproduces the idea that indigenous women do not have political agency (Rousseau \& Morales, 2015). Conversely, there is a tendency to uncritically celebrate the inclusion of indigenous women as leaders within such movements (Deonandan \& Dougherty, 2016). While the gains of Indigenous Movements are real, Webber argues that they should not be celebrated uncritically when the material conditions of the very same people remain the same (2007). Indigenous movements in Latin America were originally understood as resistance to neoliberalism; however, in many instances they have collaborated with governments, international institutions, and NGOs, which are aligned with neoliberal ideologies (Zamosc, 1994). There are also class divisions within indigenous communities that transnational movements tend to overlook as documented by Shah and his ethnographic and historical work on the Adisavi communities in India (2010). 
Studies by Rousseau (2011), Rousseau and Morales (2015), and Sharifpour (2016) analyze the gendered effects of internal organizational structures and dynamics. In a context of weak or weakening indigenous movements in national politics such as in Peru and Mexico, Rosseau \& Morales argue that indigenous women tend to form independent organizations (2015). In the case of Bolivia, the success of indigenous women as central actors within social and political movements is explained by the strength of indigenous movements (Rousseau, 2011). Sharifpour examines gender dynamics within CONAIE (Confederation of Indigenous Nationalities of Ecuador), the principal indigenous organization in Ecuador, and argues that chacha-warmi, the indigenous conception of dual gender complementarity, acts as a guiding principle for the construction of gender equality within the organization (2015). These studies, however, do not examine the barriers that indigenous women face in becoming social activists and leaders, nor do they explore how they become involved in political organizations, or how activism might affect their relationships within families and communities (Deonandan \& Dougherty, 2016, p. 275).

Addressing these questions, Jenkins shows how politically active Ecuadorian women use a narrative of a broad connection with Pachamama (Mother Earth) to justify their anti-mining activism (2015). Although such a narrative represents an essentialist conception of femininity (caring, nurturing, and giving life) and might be understood as enforcing traditional gender roles, women use it to perform a strategic role in anti-mining struggles that helps them legitimize their involvement (2015). Jenkins finds that unlike studies that place women's activism as secondary to men's activism, the accounts of the 
women she interviewed were characterized "by sustained engagement as activists in their own right, for which many of them recounted suffering violence, threats and intimidation" (2015, p. 447).

Deonandan and Dougherty present a compilation of different case studies that examine women in anti-mining struggles (2016). In Guatemala for example, women have a central presence in anti-mining struggles either in numbers (high presence of women) or in their roles, by being at the frontline of protests or by leading road blockades (2016). By confronting the exploitation brought by mining industries, women in the La Puya community in Guatemala also confront gender inequalities within their own households and communities (Muralles, 2015 in Deonandan \& Dougherty, 2016). In Ecuador, The Front of Women Defenders of Pachamama and ULAM (Latin American Association of Women), demonstrate how women are redefining themselves as political actors and are becoming an effective challenge to the authority of state (Deonandan \& Dougherty, 2016).

While it is important to recognize indigenous women's own empowerment, one should also remain critical of tendencies that romanticize indigenous women's lives while ignoring the harsh realities and restrictions they face (Deonandan \& Dougherty, 2016). Resistance and struggles require different resources such as time, and places to gather. Moreover, there are no studies that examine the differences between indigenous and non-indigenous women in mining struggles, which reflects a lack of understanding of how indigenous and non-indigenous women's participation might vary and "whether the impact of their struggles is similar, in terms of empowerment and transformations in 
social relations" (2016, p. 278).

In summary, the literature on neo-extractivism offers substantial evidence of a case of coincidental economic interests between the government and transnational companies: the former receives rents while the latter receives profits (Veltmeyer, 2013). Because the cozy but tense extractive capital-state relation occurs across regime types, this signals the consolidation of the commodities consensus (Svampa, 2012). The literature on neo-extractivism and its effects on social relations, particularly those affecting indigenous women, presents many challenges since there is a lack of empirical research that considers indigenous women's positionality in a system of interlocking race, class, and gender oppressions (Peter, 2009). Second, the body of literature presented above focuses on gender inequalities in the workplace exclusively, concluding that women should increase their participation and improve share of resources, without questioning how women are often used as cheap and contingent labor. This literature also remains uncritical of development by focusing exclusively on the benefits of economic growth (Lahiri Dutt, 2011).

To understand the extent of the effect of extractivism on indigenous women, one needs to provide a critical analysis that focuses on how the intersections of ethnicity, class, and gender make indigenous women more (or less) susceptible to the effects of neo-extractivism. The task remains to establish whether such scenarios relate to indigenous women in Latin America under neo-extractivism and how this new form of development affects them. To answer these questions, it is equally important to analyze the state's attempts to consolidate a national identity that reinforces statist centralism 
(Cusicanqui, 2015, p. 81). The following literature presents an overview of cases where the state has consolidated its hegemony by manipulating ethnicity into political identities.

\section{5. The state and political identities}

Ethnicity and indigeneity have been traditionally associated with cultural processes and identity formation, obscuring the central role that the state has in shaping such identities. Rae argues that the process of making exclusionary categories of "insideroutsider" constitutes an essential part of the state system because of the state's monopoly on defining identities (2002). Based on an analysis of the Jewish expulsion from Spain in 1492, and the persecution of Huguenots under Louis XIV, Rae argues that while the emergence of the nation-state and nationalism is where the formation of political identities is the most visible, such practices preceded nationalism and were widely used by state builders (2002). The management of differences between groups has become central to modern statecraft because in theory it ensures equal citizenship in the polity while acknowledging differences within civil society (Mamdani, 2013). In his empirical and theoretical work in Africa, Mamdani demonstrates that ethnic and racial identities must be understood as political identities because they are "the consequence of the history of the state formation" (2001, p. 654). The state grants or denies legal rights based on nationalistic notions of race (2001).

Perhaps one of the most striking cases in recent history of the state's politicization of ethnicity is the Tutsi-Hutu conflict in Rwanda that resulted in Tutsis genocide. Around 1930, Belgian colonialism constructed Hutu and Tutsi as native and nonnative identities. While both were colonized, Hutus were constructed as a native ethnicity, while the 
Tutsis were constructed as nonnative, and therefore as a subject race, an intermediary between Belgians and Hutus. Tutsis were a numerical minority, but their socio-political position as a subject race granted them privileges, particularly in relation to state positions at the local level. The 1959 revolution and the ideology of Hutu power and majority rule emerged as the antidote to Tutsi privilege (Mamdani, 2001b). The revolution led to the independence of Rwanda years later with Parmehutu (Hutu Emancipation Movement) as the party in political power, leading to an exodus of Tutsis to Burundi and Uganda (2001b). In 1990, the reversal of residency requirements back to ancestry in Uganda made Tutsis living in Uganda refugees again. Tutsis in Uganda regained citizenship in their homeland through the creation of the Rwanda Patriotic Front (RPF), and the RPF invasion to Rwanda in 1990 initiated the Rwandan civil war. The Arusha Peace accords helped ended the war and weakened the Hutu government by asking it to share power with the RPF. For many Hutus, this meant the re-Tutsification of state institutions and a reversal of power back to the Tutsis (2001b). By 1994, Tutsis in Rwanda were again constructed as a nonnative race, as conquerors in a quest to dominate Hutus. The Akazu, an extreme faction of Hutu power and an informal organization of Hutu government leaders, led to the formation of the Hutu genocidiaries. In 1994 the genocidiaries initiated the killings of Tutsis and all moderate Hutus who were opposed to genocide $(2001 ; 2001 b)$. What was perceived as ethnic conflict, was a product of the historical formation of the state. 


\subsubsection{Political identities in Latin America}

In Latin America, the state has historically shaped identities and group boundaries, particularly for indigenous groups, through various ideologies and policies that aimed to homogenize its population (Van Cott, 1994). Assimilation, mestizaje (mixing) or exclusionary citizenship mechanisms were created to consolidate the nation state (Stavenhagen, 1994). Historically, therefore, a modernist ideology prevailed where the "Indian question" could be solved by erasing the indianness of a country or by transforming indigenous people into citizens via assimilation into hegemonic cultural models (Stavenahgen, 1994). The emergence of indigenous movements in the 1980s and 1990s questioned the nation-indigeneity relationship (Van Cott, 1994). As a response, neoliberal states issued policies that were more tolerant of multiculturalism. States also recognized rights based on ethnicity in what is called neoliberal multiculturalism (Muehlman, 2009, Zizek, 1997, Laurie, Andolina \& Radcliffe, 2005, Postero \& Zamoc).

However, Healy and Paulson (2000), Muelhman (2009), and Shah (2007; 2010), argue that such attempts can be a double-edged sword since the purpose is not inclusion but redefinition of political participation, particularly confrontations and direct actions (e.g. marches, strikes, blockades, street demonstrations) into more "manageable, consensual and legitimate processes... which may ultimately dilute popular power" (Healy \& Paulson, 2000, p. 12). While the state might use a multicultural discourse of ethnicity to promote indigenous rights, when used within a neoliberal context, such discourse might be used to deny rights to the most marginalized groups, including indigenous communities (Muelhman, 2009). In an empirical analysis about the Cucapa 
indigenous communities, Muelhman shows how they were denied fishing rights because of an essentialist and legalized definition of indigeneity. The Cucapa use fish for sale, not just for traditional self-subsistence and they also use motorboats to fish. For the Mexican government and environmental NGOs, the Cupacas failed to perform the government and environmental NGOs' ideologies about the "noble savage" (the assumed intrinsic connections between indigenous people and nature). The aim, therefore, should be to understand the political dynamics of ethnicity as a strategic project and as a field of struggle between the state and indigenous peoples (Cusicanqui, 2010).

\subsubsection{Political identities, neo-extractivism and the state}

The right to prior and free consultation has been at the center of ambiguities between progressive governments and indigenous communities. The right to prior and free consultation, established by the International Labor Organization (ILO) 169 in 1989 and then strengthened by the UN Declaration of Human Rights in 2007, is a crucial juridical tool to give rights to indigenous communities in respect to projects executed on indigenous lands (Savino, 2016). According to the United Nations, the right to prior and free consultation is a principle that requires states to act in good faith by consulting with indigenous communities "before adopting and implementing legislative or administrative measures that may affect them" (United Nations, 2013). Through separate but interconnected principles, leaders from Ecuador, Bolivia and other center-left governments counteracted discrimination by strengthening the process of the right of prior and free consultation, while at the same time solidifying the capacity of the state as the main protector of nature and indigenous communities (Savino, 2016). 
Nevertheless, conflict between indigenous communities and the state endure because the state becomes a hegemonic actor in all aspects of society (social, political, economic or environmental dynamics).

In Ecuador, the progressive agenda of President Correa demanding respect for nature and indigenous communities has not translated into inclusive and proenvironmental policies. The institutionalization of prior, free, and informed consultation and the inclusion of indigenous leaders as state officials might be perceived as steps in the right direction (Arsel \& Avila, 2012). On the contrary, these processes have led to the centralization of the state as a key actor while civil society is weakened (2012). In the case of Ecuador, the state has created an aggressive path to re-establish state power via the new constitution by obtaining far-reaching powers within development politics (2012). At the same time, President Correa's references to indigenous communities and environmental groups as infantile for opposing his extractive policies, underscore tensions between the state and civil society. Because the state has a unique capacity to create and enforce a constitution and the legal rights within it, the state has the power to privilege itself as a central actor while also negating the full participation of civil society (2012).

Savino's analysis of the struggles of the Mapuche indigenous communities in Patagonia, Argentina exemplifies the tensions between the state and community life (2016). In 2003, Argentina transitioned from a neoliberal economic model to a national popular one (2016). ${ }^{11}$ However, the national popular model showed contradictions around

\footnotetext{
${ }^{11}$ The national popular model recognized the rights of indigenous communities to prior and free consultation as well as other pro-indigenous laws and policies such as the Emergency Law on Land Use
} 
neo-extractivist projects. These contradictions were evident in the Argentinian region of Patagonia, which was transformed from a neglected region into a national and regional center for economic development (2016). In 2011, the local government allowed the USbased Apache company to start the first multi-fracture oil-good operation (fracking) in Latin America without prior and informed consultation of the Gelay Ko Mapuche community (2016). Eventually consultation did occur, but it included only local leaders who had a friendly relationship with the company. This created a fracture between local communities and their leaders, a common strategy to weaken opposition and indigenous solidarity (2016). The outcome of such deep local divisions has resulted in state's hegemony in decision-making processes and "the conversion of some indigenous activists into government supporters, managers of state policies, and campaigners during elections" (2016, p. 409). ${ }^{12}$

Similarly, to reconcile resource extraction with indigenous self-governance, the Bolivian constitution includes prior, free, and informed consultations before the launching of extractivist projects. For the hydrocarbon sector, consultation, as stipulated in the constitution, requires the intervention of a third party or moderator, who, by government recommendations, ought to be a representative from the Ministry of Hydrocarbons and Energy (MHE) (Schilling-Vacaflor, 2013). In other words, the mediator is from the very bloc interested in extractive processes (Acosta, 2015). In an empirical analysis of the consultation process on the Lliquimuni oil block near the

and Ownership of 2006, which "suspended evictions from indigenous communities for four years" (Savino, 2016).

${ }^{12}$ Even though the national and popular model does not suppress social protests, indigenous communities argued that the criminalization of indigenous mobilization has been the strongest in areas of provincial governments with strong alliances to President Kirchner. 
Madidi Park in La Paz, Pellegrini \& Arismendi show how the MHE bypassed and avoided consultation with CPILAP (Central Organization of Indigenous People in La Paz, which demanded land registration before oil exploration) by picking a handful of local indigenous leaders (2016). Direct negotiations create atomistic demands and result in minimal compensations for the communities affected, creating a rupture between the supra indigenous organization leaders (CPILAP), individual community leaders, and the communities they represent (Acosta, 2015).

With regards to indigenous autonomies, the new Bolivian constitution of 2009 grants indigenous communities control over their territories by establishing institutional and political administrations that align with their own traditions and norms. The most common form of control is through the creation of autonomous municipalities or indigenous autonomies. The legal framework for indigenous self-governance includes three procedures: First Peoples and Peasant Autonomy (AIOCs), Indigenous First Peoples Peasant Territory (TIOCs), the most common process, and the creation of autonomous regions comprised by many AIOCs. However, the process of autonomy is very bureaucratic and burdensome, including demands for evidence of pre-colonial occupation of lands (Acosta, 2015). In the department of Chuquisaca, only three of 28 municipalities "undertook the application process, even though in several communities, indigenous self-identification exceeded ninety-five percent" (quoted from Acosta, 2016, p. 5, Cameron, 2013, p. 195). After autonomous status is achieved, communities must identify an institution of self-governance. The problem is that municipalities do not comprise one single indigenous identity and this process has led to the appropriation of 
indigeneity by rural elites (Acosta, 2015). Even when autonomy is granted, the state still holds authority and decision-making power over natural resources (Acosta, 2015, p. 6)

Perhaps the most iconic conflict revealing the state's ambiguous position towards indigenous rights has been the political crisis of the Territorio Indígena del Parque Nacional Isiboro-Sécure [Isiboro Sécure National Park and Indigenous Territory] (TIPNIS), a protected natural area that is also home to thousands of indigenous peoples in the Bolivian lowlands (Fabricant \& Postero, 2015). In 2011, tensions and confrontations emerged between the state, TIPNIS indigenous communities (such as the Tsimanes, Yuracares and Mojeno Trinitario) and migrant indigenous coca farmers. The reason was a government project to build a 182-mile highway through indigenous territories without prior and free consultation (McNeish, 2013). ${ }^{13}$ The government labeled indigenous communities opposed to the highway construction as "anti-development and anti-nation" (Fabricant \& Postero, 2014) and the state's response to protests was repressive, sometimes violent (Webber, 2013). Local elites labeled coca growers who were in support of the highway as colonizers and invaders in the region (Fabricant \& Postero, 2015; Webber, 2016). This conflict shows how groups who are supposed to have common ethnic interests might be in conflict with each other based on their relationship to capital development and the state (Fabricant \& Postero, 2014, 2015).

Through a case study of Jesus de Machaca, an Aymara community in the Bolivia highlands, Canessa shows that even in a region considered the greatest base of President Morales, there exist different types of relationships that indigenous communities aim to

13 This highway is part of the Brazilian Initiative for the regional integration of South America, a network of 531 mega-projects including hydroelectric dams, highways, bridges, and electrical power systems. (2013). 
build with the state (2012). These two communities have a long history of political resistance to white rule, hacienda encroachments and the state (2012). Autonomy was a long-standing demand (over a century old) for the Jesus de Machaca community. Nevertheless, in 2011, a referendum for autonomy barely passed. National and local ruling parties heavily campaigned against autonomy, arguing that the best means for obtaining indigenous rights was through the state (2012). There was also a division within the community between those who wanted autonomy in a traditional framework and those who sought greater autonomy by becoming local state managers (2012). For Canessa, these tensions highlight indigenous communities, "long struggle against the colonial, neocolonial and even an indigenous state" (2012, p. 217).

In summary, the literature on political identities, indigenous communities and the state in Latin America shows ongoing attempts by the state to create a hegemonic and dominant national identity. Historically, such attempts were assimilationist at best, where the state tried to deal with the "indian question" by exclusionary mechanisms (Van Cott, 1994). The new attempt of the Bolivian state to consolidate its political hegemony by making indigeneity the national and dominant identity has been successful. However, conflict is ongoing since the Bolivian state has co-opted and marginalized radical indigenous movements (Canessa, 2012, 2014). 


\section{CHAPTER TWO}

\section{THEORETICAL FRAMEWORK}

This study analyzes how the coincidental economic interests between a selfdeclared indigenist state and extractive capital affect indigenous women and how indigenous women organize to challenge the impact of state extractivism on their lives and communities. Because this analysis involves multiple actors in complex relations, this study draws on and integrates five complementary theoretical and conceptual frameworks to guide the research questions. These theoretical and conceptual frameworks are introduced in sequential order to explain first, the macro and abstract state-capital-civil society relations, and then to explain these relations in a micro and contextualized manner. Figure 4 shows all the theories and concepts that comprise this theoretical framework.

1. The structural mechanisms of the capitalist state (Block, 1987), describes in an abstract and general form the relationship between the state, capitalists and the working class. This theory allows us to understand the contradictions between President Morales's radical promises and his reformist policies.

2. World systems theory (Wallerstein, 1974) adds complexity to Block's schema of capital-state relations in peripheral countries. This theory locates Bolivia within the regional and global context of the international division of labor and shows that neoextractivism deepens Bolivia's position as an exporter of primary commodities.

3. The concept of accumulation by dispossession (Harvey, 2003) explains the nature of extractive capital in Bolivia and its effects on indigenous communities and the 
environment. The accumulation part explains the state-capital relation in the context of extractivism; and the dispossession part explains the state-civil society relation. At the core of Accumulation by dispossession is the process of commodification that incorporates formerly public and non-market goods, resources, and services into the market (Jaffee \& Newman, 2013). Accumulation by dispossession also drives proletarianization, which involves coercion and the appropriation of skills, social relations, knowledge and beliefs and the appropriation of culture, in what Harvey refers to as class exclusions (Harvey, 2003).

4. Mamdani's' work on political identities shows that cultural identities might be consensual, but when they are made political, then the state enforces its boundaries by legal and administrative mechanisms (2001). The failure to make an analytical distinction between cultural and political identities leads to misunderstandings of how ethnicity continues to be politicized, and how the state plays a central role in the manipulation of identities. To place this theory in context, I will use Canessa's conceptualization of indigeneity to differentiate indigeneity of the state from indigeneity of local communities.

5. Social Reproduction Theory (Bhattacharya, 2017) challenges the fictional dichotomy between production and reproduction processes. SRT shows how the lives of indigenous peasant women in rural Oruro (involved in reproduction processes) who live far away from mining sites (where production happens) are deeply affected by and interconnected to extractive capitalism. Social Reproduction Theory shows that capitalist production depends on these reproduction processes as well. SRT also 
explain how collective resistance is located within reproduction.

Figure 4 shows each theory and concept represented by a distinct color and the research question they address in the same color. The structural mechanisms of the state (Block, 1987) for example, describes the state-capital- working class relationship; therefore it is placed outside and above the triangle to represent these macro dynamics. Blue represents these macro relations.

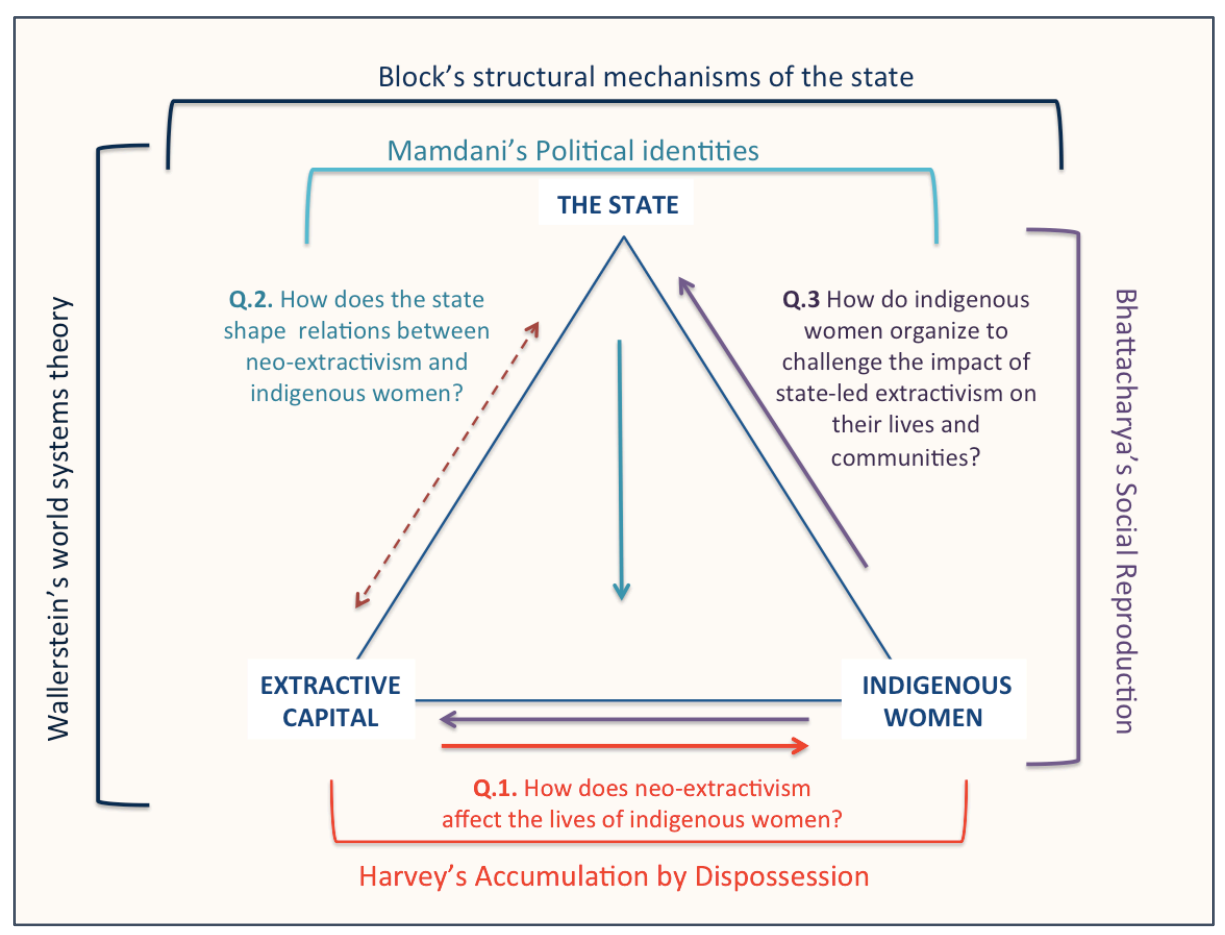

Figure 4. Integrated theoretical framework.

In combining these theoretical frameworks, this study explores in depth how neoextractivism, defined as a new logic for capital accumulation in Latin America, penetrates the social relations at the intersection of class, race, and gender among indigenous communities (Lopez \& Vertiz, 2015). By shedding light on how production and 
reproduction are interdependent systems in the context of rural and indigenous

communities in Bolivia, this study shows that capital accumulation depends on the dispossession of indigenous ways of life, where indigenous women play a central role, by making the social reproduction of the indigenous peasantry unbearable.

\section{1. Structural mechanisms of the state}

The contradictions between the Bolivian state's progressive rhetoric and its capitalist policies are explained as a default mechanism of the state serving the interests of the capitalist class. However, to assume that the relationship between the state and capitalists is merely instrumental is misleading. Such analysis simplifies and ignores the internal and external forces that influence state behavior, which emerges from the conflict between three actors: capitalist class, state managers, and the working class (Block, 1987; Miliband, 1983). Block shows that structural mechanisms, such as the state's dependency on capital and business confidence (capitalist evaluation of the political/economic climate) lead the state to favor and serve capitalist ends, even when the capitalist class does not have a direct and consciously active hand on it (Block, 1987). These structural mechanisms make the state dependent on capital flow to maintain "some reasonable level [of] economic activity" (1987, p. 57). Capitalists, on the other hand, need the state to regulate prices and exports/imports in their favor. They also need the state to reproduce the essential social order to maintain the political and economic status quo (1987). However, if the level of business confidence declines, so does the rate of investment, which affects the economy. Therefore, while capitalists need the state, they do not depend on it and they can choose to invest somewhere else. Block calls this the asymmetrical 
dependency of the state. ${ }^{14}$

In this asymmetry, the state's interests are conditioned by the neutrality it must project to the working class to maintain its own authority. While the state has some degree of autonomy in assuring both neutrality and legitimacy to both classes, the state's role is to "contain class conflict and social policies that are counterintuitive to business class interest" (Miliband, 1983, p. 59). The state-capital relationship is therefore a partnership between two actors who have similar interests, yet each has "its own separate sphere of concerns" (1983, p. 73). Progressive governments therefore are usually unprepared or unwilling to implement major social policies at the expense of offending and decreasing business confidence.

These asymmetrical relationships lead to class struggle. Yet ironically, class struggle has contributed to the state's expansion and centrality in the regulation of the economy which might lead to the provision of services and implementation of social policies, while simultaneously allowing the state managers to facilitate capitalist interests (Block, 1987). The creation of the welfare state might balance the class struggle between capitalists and workers by offering benefits to both (although the benefits to the working class are relatively minimal) and by making the working class docile to capitalist interests (Hickel, 2012 p. 5).

In Bolivia during the early 2000s, the ruling class understood that neoliberal projects and policies needed to be reshaped to maintain economic and political control in the hands of capitalists and to prevent social conflict. To maintain the centrality of the

\footnotetext{
${ }^{14}$ Chile during the 1970s illustrates this scenario when the partnership between capitalist and the state was broken due to the progressive agenda of socialist president Salvador Allende. The business confidence in Chile declined and social policies were not implemented, causing political unrest, with (of course) the help of the US capitalist class (Block, 1987; Navarro, 2006).
} 
market, political and economic elites argued that a more active state was necessary (Webber, 2010). This approach was called neo-structuralism. The new emphasis on resource extraction in Bolivia in 2005 was understood as a reaction to global high prices and high demand for primary commodities where the state had a central role in obtaining rents for social redistribution (Webber, 2014).

Neo-structuralism as a theory of development, however, ignores the conflict and power relations that are an inherent part of neo-extractivism. Rather than neostructuralism, Webber argues that reconstituted neoliberalism is a more appropriate name for Bolivia's current extractivist development model (2011). Although neo-extractivism does not support neoliberal orthodoxy, it does present the state as a neutral actor while in reality the state operates in the interest of the ruling class (Webber, 2011). In Bolivia, the poor, particularly in urban cities, have benefited from the social policies that resulted from the increase in rents and taxes on extractive capital imposed under President Morales since 2007. The expansion of child and maternal health programs are clear examples. However, critics argue that these social policies are relatively modest accomplishments that do not counterbalance the negative impact of neo-extractivism in the long term.

\section{2. World systems theory and the commodities consensus}

World systems theory (Wallerstein, 1974) and Svampa's concept of commodities consensus (2012) add complexity to Block's schema of capital-state relations and offer the theoretical tools to analyze Bolivia's position within the regional and global context of the international division of labor. Wallerstein (1974) offers a theoretical framework to 
understand how historical changes, conditioned by the emergence of global capitalism, gave rise to a modern world system organized through the international division of labor, where core countries are further developed due to their dependency on peripheral countries from which they take economic advantage (McMichael, 2012). This economic advantage takes form via the export of natural resources or the transfer of wealth from periphery to core countries (2012). On a global scale, states become part of an unequal world division of labor where capital resources and intellectual production are concentrated in core states while low-skill labor is concentrated at the peripheries of the global system (Wallerstein, 1974).

For Wallerstein, the rise of global capitalism started in the 1500s with European colonialism. To establish and maintain a capitalist world economy with Europe at its top, and to respond to the feudal crisis of the $15^{\text {th }}$ and $16^{\text {th }}$ century, Europe expanded its geographical reach by developing different modes of labor control as well as establishing strong state economies within western Europe (Hallsal, 1997). This new world economy differed from previous empire systems in that multiple core economies "directed the flow of economic goods from the periphery to the center [via] commercial monopolies combined with the use of force" (Wallerstein, 1974, n.p.). ${ }^{15}$ While the notion of a division of labor emphasizes distribution and cooperation, the international division of labor between core and peripheral regions highlights the inequalities created by this

\footnotetext{
${ }^{15}$ In his model, Wallerstein proposed four different categories: core, semi-periphery, periphery, and external, which describe the position of any country within the world system as well as "certain internal political and economic characteristics" (Wallerstein, 1974, n.p.). (For this research I will explain core and periphery regions only). The core region includes countries with strong central governments, large armies, and extensive bureaucracies (and those who were colonial empires) that make it possible for local elites within peripheral economies to control international commerce and therefore "extract capital surpluses from this trade for their own benefit" $(1974$, n.p). The periphery on the other hand, refers to regions that were colonized, although not exclusively, and those regions that lack strong centralized government which export raw materials to the core region relying on coercive labor practices.
} 
division. Wallerstein's theory identifies a supra-national structure that shapes the dependent and antagonistic relationship between core and periphery, which is dynamic and evolves with economic, historical, and political changes. This theoretical flexibility explains the emergence of China and Brazil as economic centers within traditional peripheral regions.

Within this theoretical framework, neo-extractivism as an economic model still makes Bolivia dependent on raw material export because, at its core, neo-extractivism is about the unequal international division of labor where countries like Bolivia, rich in natural resources, remain peripheral while core states take economic advantages. Thus, neo-extractivism has not changed —and is unlikely to change-Bolivia's position in the international division of labor. Neo-extractivism is a development strategy that does not challenge the constraints of the international division of labor, but rather, operates within those constraints. Bolivia and its current economic model of resource extraction should be understood by analyzing its history of overexploitation of nature that has created "the resource curse", a term popularized in Latin America by Eduardo Galeano (1997). In other words, neo-extractivism deepens the position of Bolivia within the colonial division of labor. Bolivia, therefore, is still a peripheral society, dependent on foreign investment and demands for the extraction and export of its natural resource wealth.

Nevertheless, neo-extractivism as a concept does not fully capture how the international division of labor continues to operate in the region. Moreover, it does not highlight the reckless demand for raw materials, particularly fossil fuels from core sates (Fabricant, 2015). In a more comprehensive conceptualization that includes neo- 
extractivism as a central concept but expands the mechanism under which this occurs, Svampa introduces the concept of the "commodities consensus" (2012, 2015). Like the Washington consensus, the commodities consensus marks the beginning of a new economic and political era "sustained by the boom in international prices for raw materials and consumer goods... and...the consolidation of a system of domination" (Svampa, 2012, p. 119). The demand for commodities has allowed the "re-primarization" [or the return to producing primary goods] of Latin American economies, accentuating their orientation towards primary extractive activities" (Svampa, 2015, p. 47). Even within a context of global market volatility and financial crisis, Latin America will continue with the commodities consensus as the prime development strategy (Svampa, 2012).

The commodities consensus has deepened the logic of dispossession of lands due to the large-scale nature of extractive projects and the expansion of the extractive frontier "towards territories formerly considered unproductive... and therefore, consolidating exporting enclaves associated with a neo-colonial logic with little or no connection to local production chains" (Svampa, 2015, p. 48). ${ }^{16}$ Independently of regime type, there is a regional underlying agreement on neo-developmentalism. Like its predecessor, developmentalism, neo-developmentalism follows an unchallenged discourse of development as “economic growth, productivity and modernization” (Svampa, 2015, p. 122). Unlike its predecessor, however, neo-developmentalism is not based on strong

\footnotetext{
16 This conceptualization allows a referential framework to analyze and include the consolidation of infrastructure projects that facilitate the extraction and transportation of raw materials (see for example the Initiative for the Integration of the Regional Infrastructure of South America (IIRSA), a multi country program in Latin America that includes transportation projects ("waterways, ports, bi-oceanic corridors, among others); energy (large hydroelectric dams) and communications”) (Svampa, 2015, p. 48)
} 
internal industrialization, but on mega-extractive projects (2015). If the Washington's

consensus aimed at the homogenization of the region by the implementation of neoliberal

policies, the commodities consensus aims at homogenization based on the

implementation of extractive projects within a neoliberal context $(2012,2015) .{ }^{17}$

\section{3. Accumulation by dispossession}

Extractive capital and the current land grabbing, mining induced displacement, and the territorial dispossession of indigenous peasant communities under progressive and liberal regimes result from the monopolization of wealth and power via what David Harvey terms accumulation by dispossession (2003). Harvey explains that primitive accumulation, once considered a historical stage of capitalism, has since become a dominant feature of it (2003). Accumulation by dispossession is a strategy of supporting capitalist accumulation by "the release of a set of assets, including labor power, at very low and sometimes zero costs" (2003, p. 159). Accumulation by dispossession depends on four mechanisms that are deeply interconnected: privatization, financialization, state distributions and management and manipulation of crises where "assets return to their rightful owners" (2003, p. 162). Two of these mechanisms, privatization and state redistributions, are central mechanisms that apply to this study.

${ }^{17}$ Globalization and neoliberalism are used interchangeably, and they might overlap in some aspects. However, they encompass different processes. Globalization is loosely defined as the closer integration of the economies of the world (Stiglitz, 2012). By contrast, McMichael defines globalization as a deliberate, ideological project of economic liberalization that subjects individuals and state to the forces of the market (2000). Globalization is also understood as the inherent dynamic of capitalist systems to expand its borders into unexplored geographical spaces. In this essay, I will refer only to neoliberalism which is not synonym with globalization. For this study, neoliberalism is defined as "a project to achieve the restoration of class power" (Harvey, 2005, p. 16). From a materialist perspective, class is defined as the social relations of production where rights and powers over productive resources are distributed based on the economic structure (Wright, 1997). Class in this framework is relational, a relation not only over productive resources, but also over rights and powers. How these rights and powers are distributed depends on the premises of the economic structure (for capitalism it is private ownership) where the state plays a critical role as the institution enforcing and distributing rights and powers (Wright, 2005). 
Privatization occurs when a vast array of public services and institutions (water, transportation, education, health care, universities, prisons, military) become open and/or ready to be transferred to private ownership to create new arenas for accumulation by dispossession around the world (Harvey, 2005). Financialization, a strong economic force since the 1980s, is characterized by a "speculative and predatory style" (Harvey, 2005, p. 159). Deregulation allowed the financial sector to become a center of redistribution via speculation and predation. Stock values gained centrality by merging the interests of owners and managers of capital and this in turn "led to manipulations in the market that brought immense wealth to a few at the expense of the many" (2005, p. 162).

A third mechanism of accumulation by dispossession is the management and manipulation of crisis. Before neoliberalism, crises could represent advantage windows for the working class to press the state into introducing pro-working class regulations (Block, 1987). However, the debt trap has controlled economic crises where countries are manipulated by international organizations into implementing neoliberal policies to control debt and sometimes reduce or forgive debt (Harvey, 2005). The last mechanism for accumulation by dispossession is state redistribution. The transformation of the state from a welfare state to a neoliberal model is crucial because, as Brady et al. (2009) argue, the state is the actor in charge of the allocation of income between workers, managers and owners, as well as the spending, transfer and allocation of resources and services. The state, therefore, is "always a major player in accumulation by dispossession" (Harvey, 2005 p. 156). State redistributions of income and wealth might be in the form of revisions to tax codes to provide a vast array of subsidies and tax breaks to corporations (Wright \& 
Rogers, 2011).

At the epicenter of accumulation by dispossession (or $\mathrm{AbD}$ ) is the process of commodification, which is "the incorporation of formerly public, common-pool, or otherwise non-market goods, resources, and services into the market" (Jaffee \& Newman, 2013, p. 3). Accumulation by dispossession also includes the process of proletarianization which not only affects labor and productive relations, but as Harvey shows, also includes coercion and the appropriation of skills, social relations, knowledge and beliefs, the appropriation of culture, in what he calls class exclusions (2003).

Neo-extractivism in Bolivia has transformed territories formerly considered unproductive into new terrains for AbD (Lopez Florez, 2015). These territories, rural and indigenous lands in the Andes and the Amazon, are now subjugated to the "value of the market and to the investment of transnational capital" (2015, n.p). The proletarianization required for $\mathrm{AbD}$ in this context, however, is not traditional industrial workers, but rather a "semi-proletarianized peasantry...of landless rural [and indigenous] workers, their families and their communities" (Veltmeyer, 2012, p. 61). ${ }^{18}$ The displacement of smallscale farmers, while the state solidifies its alliance with agribusiness interests by favoring agro-industrial models also represents another case of the asymmetrical relationship of class struggle based on AbD (Flores Lopez, 2015). This leads to the territorial dispossession and displacement of peasants and indigenous communities, sometimes referred to as extractive territoriality (2015). This is often mentioned as a principal way that large-scale mining affects indigenous communities, and explains the emerging

\footnotetext{
${ }^{18}$ The landless peasant movements in Bolivia and Brazil, for example, have made biofuel crop expansion (soy and sugar cane, another type of neo-extractivism not covered in this study) their main arena of contestation (Fabricant, 2015)
} 
centrality of "territorialities" as ground for contestation between communities, the state and capital (Jenkins, 2014).

\section{4. Political identities and indigeneity in the Bolivian context}

Max Weber offers a classical definition of ethnic groups as "those human groups that entertain a subjective belief in their common descent because of similarities of physical type or customs or both because of memories of colonization or migration" (1978, p. 389). Weber also explains that ethnic groups are not groups per se, but rather ethnic groups facilitate group formation "particularly in the political sphere" $(1978, \mathrm{p}$. 389) which is connected to the rise of nation states and political power. While Weber explores the subjective and political aspects of ethnic identities, he does not develop a complete theoretical or conceptual framework. Like Weber, Mamdani stresses the subjectivity of defining ethnic identities on common ancestry and shared culture, recognizing the cultural and economic dimensions of ethnicity. Mamdani, however, argues that ethnic identities must be understood as political identities and as a consequence of state formation (2001).

In his analysis of colonial and post-colonial Africa, Mamdani criticizes what he considers a narrow view of the impact of colonialism as mainly economic. African scholars focused exclusively on political economy to explain the historical development of colonial markets and market-based identities (2001). Political economy was attractive because it challenged theories of modernization that ignored Africa's colonial history. To ground colonial legacy in historical processes, market-based identities were understood as the transformation of the colonizer and colonized into the haves and have-nots. 
Nevertheless, the rise of post-colonial political violence in Africa, and conflict within classes, demanded explanations of ethnicity outside the economic realm.

Africa's post-colonial political violence was explained by the state's collapse or "the crisis of governance in post-colonial Africa" (Mamdani, 2001, p. 652). This explanation, however, echoed the rationale that colonialism was needed to "tutelage Africans who lack the capacity of building stable states" (2001, p.652). African leaders argued that the crisis of the state was the result of arbitrary and uncritical colonial boundaries placed by Europeans that did not respect genuine ethnic boundaries, therefore creating inter-ethnic divisions. For Mamdani, however, this is problematic since all boundaries are arbitrarily defined (2001). Moreover, this argument fails to recognize that cultural groups are not monolithic and timeless; rather, their boundaries are also flexible and malleable to historical and political events. Such a culturalist argument assumes that "natural boundaries of a state are those of a common cultural community" (Mamdani, 2001, p. 653). Nevertheless, cultural and political boundaries, and therefore cultural and political identities, are products of different process. Economic identities are a result of the history of development of markets, cultural ones the result of the development of communities, and political ones the "consequence of the history of the state formation" (p. 654). Mamdani's major contribution to the field therefore rests in the conceptualization of ethnicity as a political identity separated from culture and the economy. 


\subsubsection{Ethnicities as political identities}

During indirect rule in the late 1800 s, the African colonial states made a legal distinction between race and ethnicity, where natives belonged to ethnic groups, while nonnatives belonged to races. This distinction, however, was not the same as colonized and colonizer. Whereas all ethnic groups were colonized, races included colonizers (Europeans or the master race) and colonized or subject races (Tutsis, Coloureds from South Africa, Arabs, Asians, etc.). Ethnic groups were placed on a horizontal plane with each other. Races, on the other hand, were placed within a racial hierarchy, with the master race (Europeans) at top, and subject races at the bottom (Mamdani, 2001). To institutionalize distinctions between races and ethnic groups, races were governed through civil law that was defined within the framework of rights, while ethnic groups were governed by customary laws, defined within the framework of traditions and by making local chiefs the appointed authority. ${ }^{19}$ The realm of natives was traditions while the realm of nonnatives was rights (Mamdani, 2001).

After independence, conservative African nationalists argued that rights should be based on indigeneity to privilege indigenous over nonindigenous citizens, particularly to grant land entitlements (2001). Since indigeneity and the customary laws were assumed to be authentically African, the native authority was maintained, perpetuating therefore the legacy of colonialism, but this time however upside down, where "the native sat on the top of the political world designed by the settler" (Mamdani, 2001, p. 658). Because indigeneity is now the basis for rights, the contradiction is that "the nonindigenous in the

\footnotetext{
${ }^{19}$ Customary law granted a despotic authority to chiefs by fusing all kinds of powers, particularly at the local state level where "the chief combined in his hands executive, legislative, judicial, and administrative powers" (Mamdani, 2001, p. 656).
} 
postcolonial period are less and less racial and more and more ethnic" (2001, p. 659). Consequently, many of the subject races (the colonized who were made nonindigenous during colonialism) demanded to be granted rights and a corresponding native authority representation. Conflict now is transformed into a struggle for rights and native representation between ethnic groups. Furthermore, because during colonialism subject races were created to perform a middleman function for colonial powers, their demands for rights are now perceived as protection of privilege and a quest for power.

What Mamdani shows is that cultural identities might be consensual, but when cultural identities are made political, then the state enforces its boundaries by legal and administrative mechanisms. The result of the failure to separate cultural and political identities means that ethnicity continues to be politicized, and from the conflict of settler against native, it becomes a conflict of native against native (Mamdani, 2001b). As a result, the central role of the state in manipulating identities continues to be ignored and therefore the conflict is sealed as ethnic rather than political. If the political is equated with the cultural, conflict is very likely to continue.

\subsubsection{Indigeneity}

Various authors offer complementary and at times contradictory definitions of indigeneity (see Hall, 1996; Murray li, 2000; Shah, 2007, Cusicanqui, 2012; Muehlmann, 2009). In many instances, the purpose is to define who is and who is not indigenous. Discussions also emerge as to whether an essentialist definition of indigeneity based on colonial legacy is useful for sociological and anthropological research, as well as for inclusive policies (see for example Kuper, 2003). Many anthropologists have noted 
that using essentialist notions of indigeneity, even those by well-intended individuals, might lead to more harm than good (Canessa, 2014; Kuper, 2005; Li, 2002). Tsing conceptualizes indigeneity broadly, defining it as "a universal concept that spreads across cultures and engages with large numbers of different people" (quoted in Canessa, 2012, p. 155). This generalization, however, ignores tensions between a globalized concept versus one that accounts for cultural and temporal specificities that might also create new hierarchies between indigenous communities (Shah, 2007). Using Hall's concepts of articulation and positioning, Murray Li argues that indigeneity is not just imposed or invented (2000). Rather it is "a positioning which draws upon historically sedimented practices, landscapes, and repertoires of meaning [in which a group of people] ... realign the ways they connect to the nation, the government, and their own, unique tribal place... [as] contingent products of agency and the cultural and political work of articulation" (2000, p. 151). Such articulation, however, can also be a double-edged sword, since it might benefit only those who are able to articulate an official discourse (Canessa, 2014). A more sound definition, therefore, should address who has the power to articulate indigeneity and its rights and who has the power to represent a marginalized group under indigeneity (Canessa, 2012; Sha, 2007).

For the Bolivian context, Canessa proposes a conceptual differentiation between indigeneity from a nationally inclusive perspective for the majority (as proposed by the Bolivian state) versus indigeneity for local communities and for a minority that needs protection from the state (2012). To define the experience of local marginalized communities, indigeneity can be described as part of a global language of social justice: a 
sense of being disposed of, and marginalized that connects indigenous communities throughout regional areas. This definition of ethnicity, therefore, is based on a discourse of connections to past civilizations and present connections to the natural environment with a strong sense of injustice and authenticity (2012). This conceptualization resonates with most Bolivians, who "feel dispossessed and colonized by powerful global economic and political forces" (Canessa, 2012, p. 205). This conceptualization is not to distinguish between groups of indigenous people, but between diverse and sometimes contradicting indigenous discourses (2012).

Suzana Sawyer also offers a definition of ethnic identity helpful for the Bolivian context. Sawyer argues that ethnic identity is a process of constant negotiations over different matters that relate to collective notions of being. Ethnicity therefore is relational. It is not something static, but rather in the making and it is itself a terrain of struggle, "through which different groups engage in the political act of defining..." themselves and others (Saywer, quoted from Webber, 2005). The historical and social relations specific to a time and a place influence the relational aspect of ethnicity, and therefore it is always changing (2005).

The Bolivian state's version of indigeneity, on the other hand, aims to establish it as the dominant national identity. The new constitution of 2009 defines indigeneity broadly, including diverse peasant and indigenous groups as the new citizens (Canessa, 2014). ${ }^{20}$ This broad definition of indigeneity is inclusive and encompasses the more

\footnotetext{
20 This inclusive yet bulky definition of indigeneity was a result of Pacto Unido, a coalition of multiple organizations that pushed for changes in the new constitution and which were originally supportive of President Morales (Canessa, 2014). In recent years however, many of these organizations have cut ties with the government. Two of the leading indigenous organizations, Consejo Nacional de Ayllus y Markas
} 
traditional indigenous communities of the highlands and lowlands, for whom indigeneity is central for self-identification (Canessa, 2012). It also includes coca farmers, migrants who moved into urban areas and the landless peasants in the lowlands. These last three groups - the political base of Evo Morales' party — have a special relationship with the state in which they have become its very close allies. Coca farmers, urban migrants and landless peasants who might be victims of white economic elites, argue that although they lost key features of what would define them as indigenous, they were able maintain their cultural traditions. These groups, therefore, are able to claim indigenous status, "despite their re-territorialization in new geo-historical spaces" (Canessa, 2014, p. 160). These groups might be content with some symbolic representations and rights that give them status or access to land. ${ }^{21}$ Nevertheless, they reject rural and marginalized identities, even when they are connected with indigeneity (Fabricant \& Postero, 2015). ${ }^{22}$

Unsurprisingly, this new and broad definition of indigeneity, while being inclusive, is also hegemonic and favors those groups that are familiar with and engaged in market dynamics and economic growth (Canessa, 2014).

In the Bolivian case, the state has consolidated its political hegemony by becoming the main decision maker and guardian of indigenous people's rights,

del Qullasuyu (CONAMAQ) and Confederación de Pueblos Indígenas del Oriente Boliviano (CIDOB) for example, left the coalition, which provoked a violent reaction from the government and its followers.

${ }^{21}$ Within a framework of multicultural neoliberalism, the state has come to create some indigenous traditions, such as the Aymara New Year or what Rivera Cusicanqui refers as the pachamization of land (the Pachamama as mother earth) that does not conform to any particular indigenous culture.

${ }^{22}$ To illustrate these divisions, in the Chapare zone, coca farmers, who are mostly Aymara and Quechua immigrants, refer to local indigenous groups as wild Indians who do not how to use the land, savages who need to be civilized by becoming waged laborers. Moreover, coca farmers, unlike other Aymara-Quechua communities, 'engaged in cash crop monoculture... [in order to] make money" (Canessa, 2014, p. 161). These immigrants represent a new rising middle class, who do not identify as mestizo, "but [who] will choose to identify as indigenous or chola even if their lifestyles would seem to be more consonant with urban middle classes" (Canessa, 2014, p. 161). It is these groups, urbanites, coca farmers and colonists of lowlands who comprise Evo's majority. 
determining who gets these rights, how and when (Canessa, 2012; Cusicanqui, 2015). This is evident in the Mining and Metallurgic Law 535 of May 2014 that, among its stipulations, grants the state the right to bypass prior free and informed consultation with indigenous communities, by arguing that mining is a national priority (2015). In the hydrocarbon sector, if tensions emerge between parties, the meditating authority is a government official from the Ministry of Hydrocarbon and Energy, "the very faction carrying out extractive processes" (Acosta, 2015, p. 9). Indigenous autonomy, another promise within the new Constitucion Politica del Estado (or CPE, the New Bolivian Constitution) has been at best a very bureaucratic system, allowing only a few communities to become autonomous, and even when that is achieved, the state continues its control of natural resources, even when such resources are in indigenous autonomous territories (Acosta, 2015). Conflict then, is neither about what type of economic development there should be, nor even a question of development per se, but rather who should control and distribute resources. In this sense, the Morales government has achieved what previous governments failed to achieve: central managerial state governance through the co-optation and subordination of indigenous movements (Canessa, 2012; 2014). In other words, President Morales is reshaping the indian-state relation by turning indigeneity upside down, from a category that historically represented exclusion and ethnic heterogeneity to one that is inclusive, homogeneous, and national. Yet national indigeneity has the potential to exclude marginal indigenous communities even with an indigenist state. By downplaying hierarchies, historical and market-relation differences between indigenous communities, the state not only ignores conflicts between 
groups but also exacerbates them (Canessa, 2014). To illustrate, President Morales and indigenous migrants from the highlands share the perspective that lowland indigenous people (in the TIPNIS region) are unproductive and do not know how to work the land. According to President Morales and his supporters, these indigenous communities are wasting resource-rich territories (2014, p. 164).

\section{5. Social Reproduction Theory (SRT)}

The realm of capitalism and production might seem independent from oppression based on gender, but various authors counter-argue this claim. Eisenstein for example, criticizes the dichotomous analysis that often studies sex and economic class separately, either as social relations of production or social relations of reproduction, but never both (1999). Therefore, the dialectical relationship between these two oppressive structures is obscured. Nevertheless, if the oppression of women is ever to be understood, a method of analysis must make this interconnection central and must be based on its historical and dialectical nature. Moreover, Eisenstein criticizes studies within political economy that are often presented as if "labor has no actual body —no home that actually creates it" (2015, n.p). While attention is given to production processes, such as women working within mining industries, social reproductive processes around mining industries are ignored. Yet, in the context of rural Bolivia, peasantry and mining, extractive capitalism depends on the continuity (or discontinuity) of these very social reproductive processes.

To elucidate this issue, I will use Social Reproduction Theory (SRT). As Bhattacharya (2017) explains, the concept of social reproduction refers to the beliefs, attitudes, activities, behaviors, emotions and relationships that are "directly involved 
in the maintenance of life on a daily basis, and intergenerationally" (Bhattacharya, 2017, p. 6). This broad conceptualization captures various kinds of social, mental, physical and emotional work necessary to provide the historical, social and biological means for maintaining and reproducing populations. Social reproduction therefore is a multiplicity of generational activities to provide food, clothes, and shelter for the worker, as well as socialization for children, and care for the elders (2017). It refers to all the activities related to domestic labor that reproduce daily life, such as washing clothes, and cooking. This also include those activities that reproduce the worker, such as childbirth and raising children, as well as all the activities in which capitalist social relations are constantly reproduced (Smith, 2013). Social reproduction, however, is not just confined to the domestic or family sphere.

As a theory, SRT examines and criticizes the dichotomous analysis of production versus reproduction, arguing that first, "human labor is at the heart of creating or reproducing society as a whole" (Bhattacharya, 2017, p. 2). SRT states that the capitalist system is not just about workers and owners, but that there are wider social processes that support the drive of accumulation (p. 2). In other words, capitalism depends on activities external to it, which are nevertheless deeply connected to production processes. SRT therefore stresses the relational link between market and non-market relations rather than just pointing to their differences (p. 14).

Second, SRT states that oppressions are not byproducts of atomized units that arrive at an intersection, but rather oppressions are structurally related to the capitalist system. SRT explores the co-production of oppressions with the production of surplus 
value and their simultaneous effects. SRT is critical of intersectional theory for its assumption of the autonomy and atomization of parts that somehow arrive at an intersection and connect through a unifying force like the market. Rather, SRT explores the ongoing dialectical relationship of such parts and the transformations, dynamism and self-transforming aspects of social life (Bhattacharya, 2017, p. 103). In offering this critique, SRT does not dismiss intersectional theory, but rather, it problematizes it by offering a more nuanced perspective than just additives. Third, SRT explores the duality of the capacity of labor. SRT argues that along with the capacity for labor, workers also have the capacity and need to reproduce life as a whole. As Ferguson highlights, it is "important to remember that we are not just reproducers of labor power, we are also reproducers of life" (2017, p. 130). These two competing aspects of labor depend on how capitalist and state forces condition the ways in which they are expressed, supported or repressed (2017).

Applying SRT in the context of indigenous peasant communities in Bolivia shows that their social reproduction processes, although located far away from mining sites (where production happens) are deeply affected by and interconnected to extractive capitalism. Since extractive capitalism does not rely only on labor, but also land and its resources, the social reproduction of the peasantry becomes redundant; therefore, this leads to appropriation of their lands and their expulsions. An important claim that SRT makes that applies to this study is that a new definition of "the worker" is needed, one that is not based on just an economic fundamentalist idea of wage labor, but one that includes people in charge of reproducing themselves and society. By doing this, 
Bhattacharya suggests that reproduction is a central site of class conflict and the working class an important revolutionary subject (2017). Therefore, class struggle is not just about wages. Since the worker is reproduced outside the workplace, struggles include other conditions that affect social life, such as housing, health, and the commons. SRT also explain how collective resistance is located within reproduction sites. In this context, the communities whose ways of life — that is, social life — are made impossible to reproduce due to the contamination of soils and water, lead the struggles against mining contamination.

In summary, to capture how macro state-capital relations affect micro dynamics within civil society and vice versa, this study draws on and integrates five complementary theoretical frameworks to guide the research questions. This theoretical framework offers a general and broad understanding of the political economy of neo-extractivism to then examine how neo-extractivism affects the lives of indigenous women in the context of Bolivia. In using this integrated theoretical framework, this study addresses Eisenstein (1999) critique of studies on political economy, which often ignores that might overlook the gendered and racialized processes of these macro dynamics 


\section{CHAPTER THREE}

\section{FIELDWORK SETTING, DATA AND METHODS}

To study the impact of neo-extractivism led by a socialist, indigenist state, this study analyzes the following research questions: 1) How does neo-extractivism affect the lives of indigenous women? 2) How does the state shape relationships between neoextractivism and indigenous women?, and 3) How do indigenous women organize to challenge the effects of state-led neo-extractivism in their communities and their lives?

To answer these research questions, I conducted a focused multi-sited ethnographic study (Knoblauch, 2005; Marcus, 1995) consisting of five months of fieldwork between October 2017 and June 2018 in two municipalities in Oruro, Bolivia (Machacamarca and Poopó) that are affected by mining contamination. This multi-sited ethnography also included fieldwork in the city of Oruro.

To collect data, I used three research methods: semi-structured interviews, participant-observations, and focus groups. I conducted 27 semi-structured interviews with four subsets of participants: a) women community leaders; b) key community actors; c) CEPA (Center for Ecology and Andean Communities) representatives and; d) government officials. Moreover, I conducted two focus groups with members of Wasi Pacha, and Las Ramonas, two collectives of young people involved in anti-mining struggles and other related issues.

Before presenting the data and methods in more detail, this chapter starts with a description of the fieldwork setting for this study in the department of Oruro, Bolivia to offer a broad understanding of the geographical as well as socio-political importance of 
mining contamination in this region.

\subsection{Fieldwork setting}

The welcome entrance to the city of Oruro (a rounded plaza located at the beginning of the main highway connecting the city of La Paz and Oruro) has an emblematic 20-foot diameter miner's helmet made of tin and burnished metal. In a city full of legends, traditions, and myths, this monument attests to the deep and intricate economic and socio-cultural relationship between mining and Orureños (people from Oruro) that has persisted for millennia, before and after the arrival of European colonizers nearly 500 years ago. Oruro is located in Bolivia's high plain, el Altiplano, the wide, mostly-flat region of the Central Andean Plateau that is found between the towering mountains of the Eastern and Western Cordilleras of the Andes (Gareca, 2009). This unique location in the high desert of the eastern el Altiplano gives the city an almost surreal ambiance among the immense brown mountains and the multicolored plains of the plateau. Similar to all desert landscapes, the imagery of el Altiplano is that of unfertile and lifeless lands, shaping perceptions around what is possible and what is not in this arid region. Nevertheless, while this imaginary is partially truth, it also conceals the state's ongoing bias against peasant economies that has manufactured the perception that el Altiplano cannot produce or support agrarian economies, therefore deeming the eventual decline of indigenous campesinx communities inevitable.

The ethnic composition of el Altiplano is predominantly indigenous, comprising Quechua, Aymara, Kallawaya and Urus populations (Vidaurre, Paniagua \& Moraes, 2006). The first two groups, Quechuas and Aymaras, comprise the indigenous 
majority of the Bolivian population and the last two groups, Kallawayas (itinerant traditional healers) and Urus (the people from the lake), are indigenous minority groups. La cosmovisión, the worldview, of the Andean peoples is based on Pacha, an Aymara word that comes from Paya (two) and Cha (strength) meaning a duality of forces between time and space (Zenteno, 2009). ${ }^{23}$ Pacha also means earth, and it is mostly used in reference to Pachamama (mother earth or earth goddess). Nevertheless, Pacha is more complex. The cultural center Kawsay defines Pacha as the "integral cosmos" that includes time, space, situationality, and states of being simultaneously (2009). Pacha therefore embodies the Andean cosmovision of duality, where Pacha interweaves the world around-that is nature and its beings-with that above, the cosmic: "Pachanx taqi phuqhataw utji, ukat taqi kunaw pachankaraki pachampirakiwa" [Pacha is everything that exists. Everything is from Pacha and everything is in Pacha] (quoted from Ardeleanu, 2014, p. 52). Pacha also expands further than time and space since these forces emanate from earth and the cosmos that emanates from heavens (Ardeleanu, 2014). Pacha therefore is a way to look at and understand the world around and it is interwoven with the natural processes of earth and the skies, which in Andean cultures is reflected through agricultural cycles. In other words, Pacha is "a distinct and dynamic epistemology" of the Andean peoples (2014, p. iii). Unlike linear conceptualizations of

\footnotetext{
${ }^{23}$ Indigenous peoples in the Bolivian Andes do have socio-cultural differences, and they have also experienced tensions among them. In Part II, I describe how the Urus are discriminated against by Quechua and Aymara communities and excluded from land ownership under the essentialist excuse that they are traditionally fishermen. At the same time, their cultures share important similarities and they have experienced significant exchanges. Moreover, indigenous communities in Bolivia have been historically unified in their demands for indigenous liberation. Here I refer to a pan-Andean cosmovisión that is rooted in the three notions of duality, reciprocity and complementary that seem central to all these indigenous groups. Nevertheless, indigenous cosmovision as a topic within this research was under-explored. As a theme, this emerged close to the end of my fieldwork and during data analysis. Nevertheless, the literature review on this topic confirms its importance. Here I want to present this information as part of the description of field settings and background that later will help to explain some of the findings.
} 
the cosmos, Pacha is non-linear; therefore time is cyclical, as in the cycles of agriculture, and rather than being behind the present, the past in Pacha is forwarded. In Andean cosmovisión, space encompasses four sacred elements that are deeply intertwined: Manqha-Pacha, the world within earth; Kawki-Pacha, the unknown, invisible realm; Aka-pacha where we currently live, and Alax Pacha that represents a superior energy (Zenteno, 2009).

This cosmovisión has allowed Andean peoples to create their own social, economic, religious, and political structures (2009). Moreover, although the dominant group within Bolivia, white European descendant elites, who are a minority in numbers but have political and economic control over the majority, have tried to erase these indigenous imprints, Andean epistemes and practices have permeated Bolivian culture and vice versa. Religious blending or syncretism is widespread and shows how different belief systems have been integrated, sometimes by exchange, often by force. In the daily life of Bolivians and orureños, in both rural and urban areas, Andean cosmovisión translates into widespread socio-cultural practices marked with many rituals to Pachamama such as la ch'alla, a ritual that in its simplest form demands that when people drink (especially alcoholic beverages), a few drops be spilled to the ground to show respect to it. In its most elaborate forms, usually after a house construction is finished, or for the opening of a business, la ch'alla involves a celebration with musical bands, traditional food, drinks, and a mesa, a sacrifice that consist of a sullu, a llama's fetus, with handmade sculptures that represent luck, good health, money, plus copal, coca leaves, and other plants to be burned and/or buried on the ground. In rural areas, Andean 
epistemes translate into the reliance on bio-indicators, or the readings of nature, as Don Oscar, an indigenous campesinx and agro-ecologist from the community of Peñas, Oruro explained. ${ }^{24}$ Participants in this study also referred, for example, to the dancing or playing of the sheep before a frost arrives. There were also stories about the leqe leqe, an Andean bird whose nest's position helped to predict upcoming droughts. There are also the Kallawayas, and their millenarian knowledge of the use of more than 900 medicinal plants, who in the past were discriminated for their traditional practices and usually relegated to rural areas, but who in recent decades have become more popular among urban dwellers, particularly in the urban indigenous city of El Alto (Vidaurre, Paniagua, $\&$ Moraes, 2006).

Ayni, a socio-economic system based on reciprocity, complementarity and kinship, is also prevalent in multiple practices and customs in the cities and rural towns (Ravindran, 2015; Ayni Bolivia, 2018). ${ }^{25}$ There is pasanaku, a rotational loan (and a good way to avoid loans from banks) where people in a group (usually 5-10) contribute some amount of money each month. Once a month, a different person within the group receives the total monthly sum and pasanaku ends when everyone in the group receives back the money they contributed (Campos, 2013). And there are the kermesses, secular small festivals from Puritan origins with the goal of raising funds. There are also the prestes, which are pompous celebrations and parties that an individual, called a pasante, organizes for his/her social group (friends, family, sports clubs, entire communities, neighborhoods, etc.). Although the pasante covers most expenses, people within

\footnotetext{
${ }^{24}$ I use pseudonyms for all participants in this study. I explain this in detail in the section of data and methods.

${ }^{25}$ In Bolivia kinship relationships are based on blood relations as well as common ancestry, particularly among rural communities and also made through social bonding.
} 
his/her/their group are expected to offer economic support by paying for the live band, food, and drinks, therefore embracing the notion and practice of Ayni, as well as strengthening kinship and non-kinship relationships, such as compadres and comadres (names for a child's godparents, but in this context referring to the deep social relationships that are built between the parents and godparents of a child). ${ }^{26}$

The department of Oruro has been an important mining center since colonial times; however, this economic dependency on mining has not translated into economic benefits that one might expect for this town or department. While the departments of Oruro and Potosi are Bolivia's major producers and exporters of minerals, they also have the highest poverty indices and the lowest life expectancies within the nation (Gruberg \& Andreucci, 2015; Instituto Nacional de Estadistica, 2013). Figure 5 shows both mining concessions for exploitation and exploration. The city of Oruro is located above lake Uru Uru, approximately 45 minutes by bus. Lake Poopó is located in the eastern half of the Oruro department and in 2002, it was designated a conservation site under the international treaty for the conservation of wetlands known as Ramsar (Sanchez, 2009; CEPA, 2009) Mining also leads to an extensive detrimental socio-environmental impact, which is particularly striking since there are other dominant economic activities in this region.

\footnotetext{
${ }^{26}$ Not everything in the Andean world, however, is rosy and guided by these practices. As Horacio, a Bolivian ecologist I met in Oruro explained, the Aymaras have also been heavily influenced by capitalistic and colonialist logics that have create marked class divisions within communities. Pompous celebrations such as prestes, according to him, are a way to redistribute surplus. Besides, prestes also represent and signal social status, economic power and the social position of the pasante, who is usually part of the indigenous petit bourgeois elite which recently has benefitted from the economic boom (this includes traders, mining cooperativists, and coca farmers). While prestes include reciprocity practices, they also include a lavish exhibition of wealth. In 2018 a pasante in the Corque community in Oruro brought to his party the German band Modern Talking. When my brother told me this story, I did not understand what he was talking about since I could not associate the rural context of Corque with Modern Talking. Anecdotal conversations estimate that such parties, some of which receive public funding (such as annual city parties), cost around $\$ 200,000-\$ 500,000$ US dollars.
} 
These other economic activities include subsistence agriculture (quinoa, potatoes and habas, also known as fava beans), and animal husbandry and/or livestock, such as camelids (e.g. llamas), bovines (e.g. cows), and ovines (e.g. sheep) (Gruberg \& Andreucci, 2015).

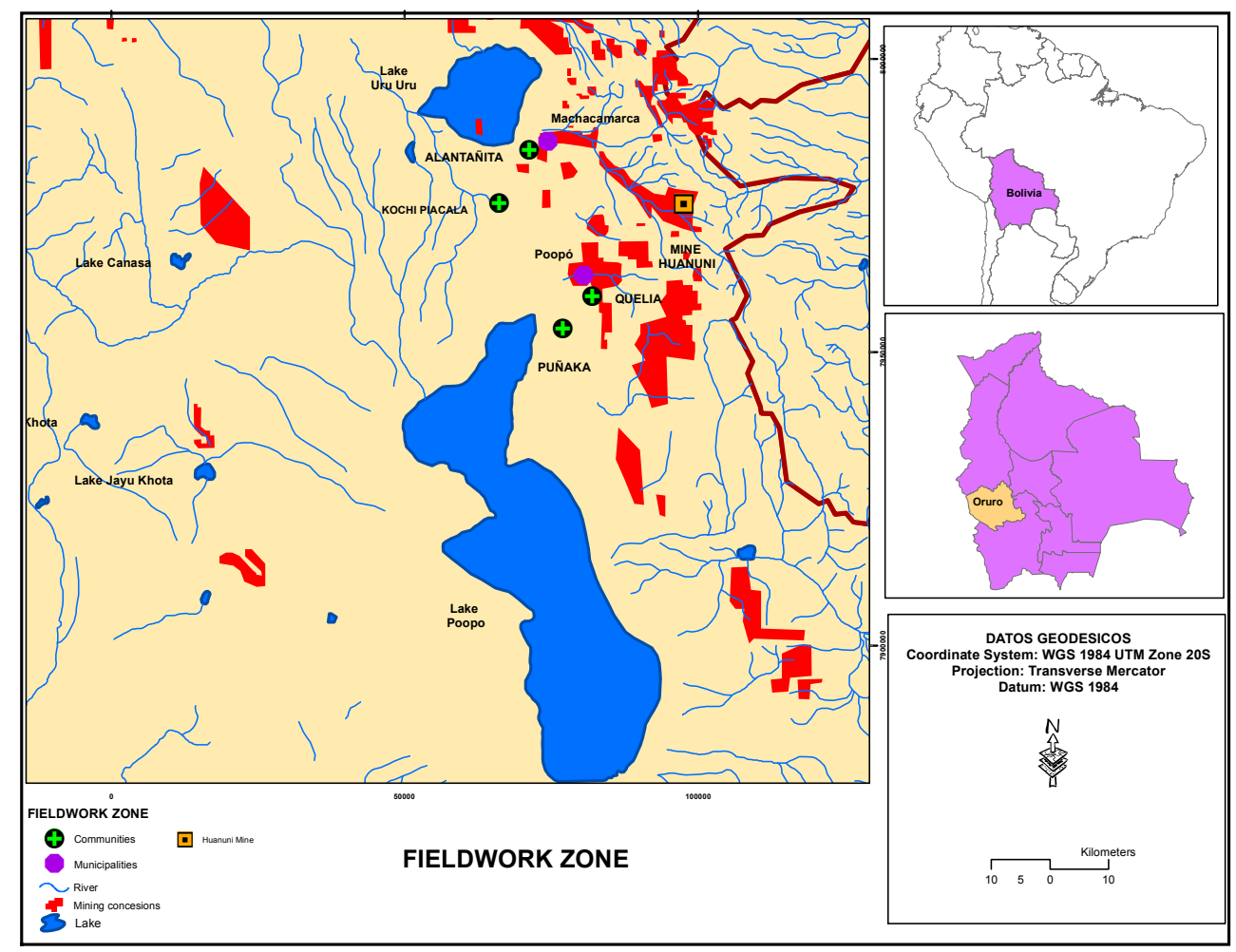

Figure 5. Fieldwork map for this study. Elaborated by Rodriguez Montoya (2019).

Another aspect (often taken for granted) concerning the historical mining character of Oruro is its presence in kinship and communal relationships. The interviews with participants as well as random conversations with people such as taxi drivers, family and friends, and people in the markets revealed that approximately one in three people in Oruro have had a family member working in the mines at some point in their lives. In my own family, my two grandfathers worked for mining companies and my mother sold 
vegetables for the Chicote Grande mining camp. In 2017, my nephew worked as a juku for almost year. ${ }^{27}$ On the surface, the social relevance of one in three people working in the mining sector might not be apparent; however, within the context of anti-mining struggles in these indigenous campesinx communities, a major issue is the internal community divisions and tensions between those who work for the mines, and those who work in the fields as campesinxs and whose lands and water sources are being contaminated. ${ }^{28}$ In Part II, I also explain how such a miner-campesinx dichotomy presented in some studies simplifies the fluidity within communities, as well as the complexities of individuals who are sometimes engaged in both practices either simultaneously or sequentially.

Although Oruro’s economy has been mining-centered since colonial times, in recent decades the city's mining sector has experienced significant economic and political shifts, giving rise to three important actors within this sector: transnational companies, mining cooperatives, and newly nationalized mines (Perales, 2010). Between 2003 and 2011, there was a significant rise in mining activities due to the increase in prices and demand for minerals worldwide (Gruberg \& Andreucci, 2015). In the Poopó basin alone, the fieldwork site for this study, which has a predominantly indigenous campesinx population and where two of Bolivia's most important lakes are located, Uru

\footnotetext{
${ }^{27} \mathrm{Juku}$ is a Quechua word for mineral thieves, usually young males who enter the mines at night to steal minerals and the tools and equipment from waged miners. In recent years, Jukus' activity has been penalized with significant jail time, especially when this activity is realized in the nationalized mine of Huanuni (Poppe, 2003).

${ }^{28}$ There is also the historical and political influence of miners. The extremely harsh and exploitative conditions of working within the mines, the very activities that, according to Bolivian historians, have been able to develop the country, have created a national respect for miners (although this is in decline due to recent conflicts among miners from different sectors and the unquestioned support that the government has offered to this sector). There is also the radical history of miners' unions, perhaps the most militant workers in Bolivia, who, in alliance with the POR (Revolutionary Workers' Party, a Trotskyist organization) became key actors during the 1952 revolution (Becker, 2011).
} 
Uru and Poopó lakes, it is estimated that there are currently 570 mining operations (2015). These operations include small and informal mining, such as cooperatives, and large-scale mining activities such as those of Sinchi Wayra, a private mining company subsidiary of Glencore, one of the principal extractive multinationals in the world, as well as the newly nationalized Huanuni mine (Lucha de Clases, 2011).

Contamination provoked by the Huanuni mine, particularly of water sources, has led to community-organizing efforts, with a significant participation of indigenous campesinx women as community leaders within CORIDUP (Perales, 2010). CORIDUP is a community-based organization that represents more than 80 communities with the primary goal of demanding solutions and reparations for mining contamination in this region (Horowitz \& Watts, 2017). In 2009, the organizing efforts of CORIDUP resulted in the creation of Supreme Decree for Environmental Emergency 0335 (SD 0335), which defines strategies for the environmental reconstruction of the Huanuni sub-basin (PAHO, 2012). Recently, in 2016, it was revealed that a combination of factors including climate change, drought, and mining contamination had led to the nearly complete disappearance of Lake Poopó, Bolivia's second largest lake (Perales, 2010). Such news attracted national and international attention to the impact of mining contamination in this area; however, this has not yet led to significant mitigation projects.

\subsubsection{Communities for fieldwork}

Four communities were identified to participate in this study: Alantañita and Kochi Piacala, in the municipality of Machacamarca, and Quellia and Puñaka, in the 
Poopó municipality, all within the Poopó basin. ${ }^{29}$ These communities are located between Lake Uru Uru and Lake Poopó, and they are indigenous campesinx communities. ${ }^{30}$ They are indigenous from their ethnicity: they are predominantly Quechua (but there are also Aymaras); the majority speaks Quechua, as well as Spanish, and they have maintained many cultural traditions, including rituals like Ayni, or reciprocity, where one person helps another in exchange for a similar favor. They are campesinx, subsistence farmers, in their social economic class (Perreault, 2014). The four aforementioned communities are all heavily affected by the contamination produced by the nationalized Huanuni mine and therefore they are part of CORIDUP. Figure 6 shows in red spots both mining concessions for exploitation and exploration. The green cross within the black circle represents the four communities for this study. The orange square represents the Huanuni mine. The purple circles represent the two municipalities (Machacamarca and Poopó) where these four communities are located). The tiny blue lines represent the rivers in this area.

\footnotetext{
${ }^{29}$ Oruro is one of nine departments of Bolivia. The city of Oruro is the biggest town within the Oruro department. The Oruro department is divided into municipalities and these municipalities have cities with the same names: Machacamarca and Poopó, for example, are important towns within the Machacamarca and Poopó municipalities. Then there is the Poopó basin that includes all municipalities and communities mentioned in this research. Poopó is also the name of Bolivia's second largest lake.

${ }^{30}$ The National Statistics Institute and the 2012 census show that indigenous campesinx communities in this region are bilingual (Spanish and Quechua); therefore, the need for an interpreter was not expected which made fieldwork and interviews easier. In case an interpreter was needed, my plan was to contact a person from a nearby community who was fluent in both languages and familiar with the local and cultural context of these locations. While I am not fluent in Quechua, I know some basic phrases and words that helped set a welcoming tone for interviews. Luckily, all my participants were bilingual.
} 


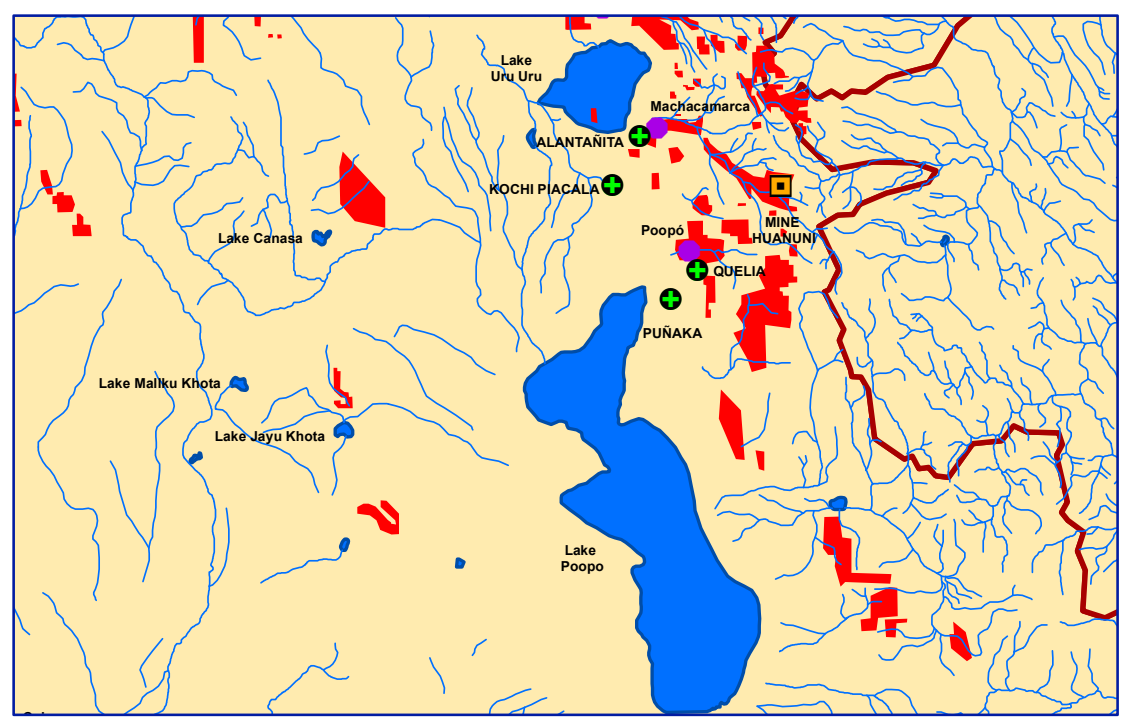

Figure 6. Communities for Fieldwork, Oruro, Bolivia. Elaborated by Rodriguez Montoya (2019).

It is also important to understand that indigenous campesinx communities in el Altiplano belong to Ayllus. The political, territorial and organizational structure of indigenous campesinx communities in the Bolivian highlands is complex, and goes beyond national, administrative and territorial divisions. The Ayllu, a Quechua word meaning extended kinship, is an indigenous organizational structure that includes an array of multiple communities within a region, from three to up to fifteen communities (Fabricant, 2010). Its origins date back to pre-Hispanic times where Ayllus where the organizational unit of the Inca empire (Burman, 2015). Each Ayllu has a leadership body, with the Tata Mallku (Aymara word that means condor, or lord of the mountains and skies, and it also means leader) as the maximum indigenous authority that is in charge of political and administrative decisions related to communal landholdings such as TCOs (Tierras Comunitarias de Origen) [Indigenous Communal Lands], land redistribution, and community tax collection, among others (Fabricant, 2010). The Ayllu democracy is 
rotational and inclusive, based on "extensive consultation with the bases" (2010, p. 94). This means that every family within a community must hold a leadership position that usually lasts one year within every five-year period. This inclusive and rotational mechanism has opened an important, yet unequal, space for women to become leaders since the Tata Mallku (male indigenous leader) must have a female counterpart, the Mama T'alla (female indigenous leader). These two positions are usually given to couples (married or in formal union). Ayllus therefore, are indigenous organizational structures legitimately recognized within the constitution, and as some participants described, have the same, or greater, political power as regional government officials. ${ }^{31}$ Figure 7 shows the election of the Jach'a Carangas Suyu (highest indigenous organizational structure that include many Ayllus). The picture to the left shows the new indigenous authorities receiving their positions. The picture to the right shows the next day celebration, where communities receive the sun on top of a sacred mountain.

31 There are two additional layers of indigenous political and territorial organizational structures: the Markas and the Suyus. Both are political or social units related to territories, where the Marka encompasses a group of Ayllus (referred as minor unit) and the Suyus encompasses a group of Markas (major unit). In the department of Oruro there are four Suyus: the Jach'a Carangas, Jatun Killakas, Chipayas and Suras (Mamani, 2018). I participated in a three-day meeting of the Jach'a Carangas Suyu for the election of its new leaders. Based on their discussions, the role of the Suyus is to provide some general guidelines and perspectives for Markas and Ayllus about a vast array of topics, including food sovereignty, indigenous youth participation, cultural revival, and mining contamination, among others. 

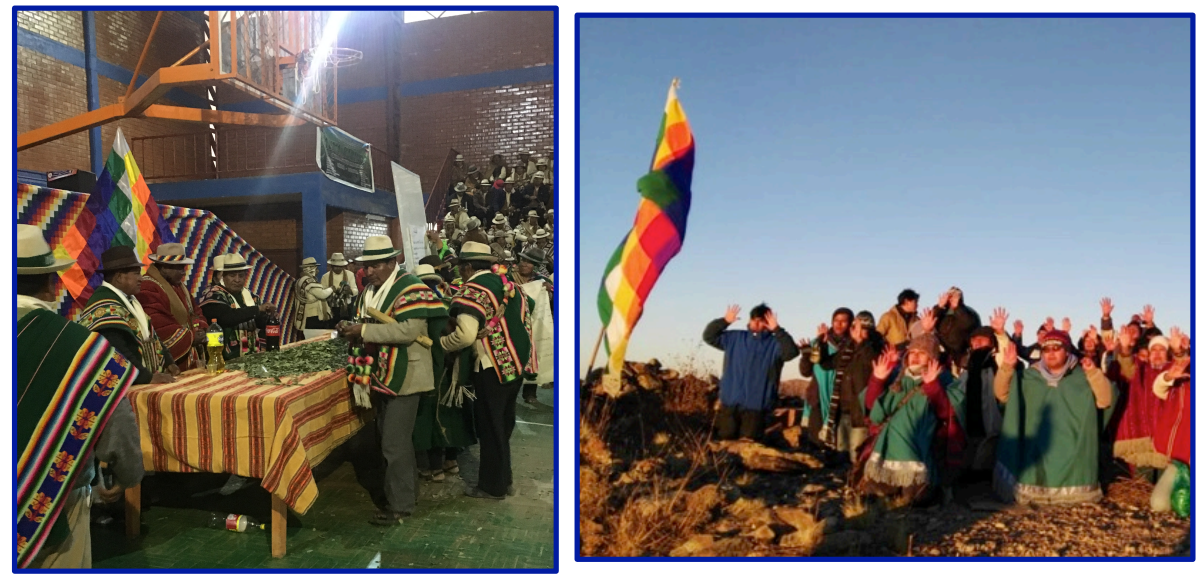

Figure 7. Ayllus, Markas and Suyus: Nations within a nation. Photograph by the author.

What is central for understanding the extent of contamination by the Huanuni mine is that these four communities are not located in close proximity to it. They are located downstream from the mine, approximately two hours by bus. According to environmental and legal regulations, only communities within two kilometers (1.25 miles) from mining centers are included in compensatory measures. Alantañita is approximately 30-45 minutes walking distance south of the outskirts of the town of Machacamarca, which is an hour from the city of Oruro by bus. Kochi Piacala, which in Quechua means lagoon, is further south, approximately two hours walking from the Machacamarca town. Quellia and Puñaka are located in the Poopó municipality, approximately a one-hour walking distance from the town of Poopó town (which is two hours from Oruro) and approximately two hours walking distance from Lake Poopó. There is neither public transportation nor demarcated roads to these communities. One has to arrive first at the towns of Machacamarca and Poopó and then either walk, or arrange private transportation via bus, car or a motorbike. Because there are no demarcated roads, comunarix, or people from the communities, usually help each other to 
arrange transportation and help visitors and outsiders unfamiliar with these communities. During the rainy season (November to February) only motorbikes or trucks are able to travel on the muddy roads, which means people have to have well-coordinated plans in advance to travel. Another important aspect about these communities is that they are located within agro-mining municipalities, meaning that the main economic activities are both agriculture and mining (the exception is the El Choro municipality, which is agricultural only).

The first impression when one arrives in these communities is that of a semi desert and a salt flat. Las tierras salinizadas, or salted soils, represent a major constraint to agricultural activities since salinization does not allow plants to grow. Prior to the modern environmental and socio-political problems, these communities were major producers of different types of potatoes (there are at least 4,000 types of potatoes from the Andes), as well as habas (fava beans, a herbaceous green plant), and quinoa. Participants mentioned that there are also many types of grasses that grow in these areas, although not as much anymore due to contamination, which are important for their curative and traditional qualities. Among these grasses are Totora, Kempara, Liwi, Muñu Muñu, Likachu, and Sebadilla to name a few. Another characteristic of these communities is the high rate of immigration to urban cities due to many factors, including mining contamination, which according to participants has played a major role on this diaspora.

The people who stay in the communities, comunarixs [community members] are usually women and elders whose prospect of finding jobs in the urban cities is minimal. 
Men (ages 21-55) are more likely to find jobs. Often times, these comunarixs have family members (predominantly men and younger generations) who have migrated to the major cities in Bolivia, as well as Argentina and Spain, in search of work opportunities. These migrants might send remittances back to support their families; nevertheless, such remittances are not common since rural immigrants also struggle to find work in the cities, particularly those displaced within Bolivia. And as one participant explained, these migrant family members play the role of a safety net, providing extra economic support in emergency cases only, such as helping for bank loans to avoid hefty fees. The people who migrate to urban centers, younger generations and older men, usually engage in different and overlapping economic survival strategies, from unwaged informal labor activities like selling food and items on the streets to waged labor, although the latter is uncommon. In urban towns and cities, indigenous campesinx women predominantly work in the informal sector, selling food on the streets, in petty commerce or as domestic labor. Men are usually involved in waged (but precarious) labor, such as plumbers, stonemasons or taxi and bus drivers. As participants explained, the majority of these migrants also rely on temporary subsistence agriculture or animal farming (back in their communities) since they still keep their land and links to their communities (I explain this in further detail in Part II).

As described in Table 2, each of these communities has approximately four to ten families that reside permanently there. The population category in Table $\mathbf{2}$ includes all the families from each community, which might or might not live there or families who live only temporary in the communities (1-2 days a week or monthly). The number (\#) of 
families in the community shows the number of families who live permantently in each community. These families are typically comprised of older adults (above 50 years of age) who engage in subsistence agriculture as well as raising livestock, such as cows and sheep. Nevertheless, the total population of each community includes those who live there permanently and those who do not (these latter group referred as residentes). These communities' success with growing crops is irregular. In 2018, because of unexpected heavy rains and major floods, Quellia and Puñaka were able to harvest crops, but in previous years such attempts were unproductive. Alantañita has some TCOs (Tierras Comunitarias de Origen [Communal Indigenous Lands]) that are located further away from the nearby rivers, which means this land is not as contaminated, and some families have been able to grow some crops there.

Table 2. Characteristics of the communities in this study

\begin{tabular}{|c|c|c|c|c|}
\hline & Puñaka & Quellia & Alantañita & Kochi Pi acala \\
\hline $\begin{array}{l}\text { Population (\# } \\
\text { of families) }\end{array}$ & 140 & $80-120$ & $140-160$ & 120 \\
\hline $\begin{array}{l}\text { \# of families in } \\
\text { community }\end{array}$ & $6-8$ & $6-8$ & $8-10$ & $4-5$ \\
\hline Ethnicity & $\begin{array}{l}\text { Indigenous- } \\
\text { peasant }\end{array}$ & $\begin{array}{l}\text { Indigenous- } \\
\text { peasant }\end{array}$ & $\begin{array}{l}\text { Indigenous- } \\
\text { peasant }\end{array}$ & Indigenous-peasant \\
\hline Language & $\begin{array}{l}\text { Quechua and } \\
\text { Spanish, }\end{array}$ & $\begin{array}{c}\text { Quechua and } \\
\text { Spanish }\end{array}$ & $\begin{array}{c}\text { Quechua and } \\
\text { Spanish }\end{array}$ & $\begin{array}{c}\text { Quechua and } \\
\text { Spanish }\end{array}$ \\
\hline Activity & $\begin{array}{l}\text { Agriculture }+ \\
\text { Mining }\end{array}$ & $\begin{array}{l}\text { Agriculture }+ \\
\text { Mining }\end{array}$ & $\begin{array}{l}\text { Agriculture, } \\
\text { some mining }\end{array}$ & Agriculture \\
\hline $\begin{array}{l}\text { Water } \\
\text { provision }\end{array}$ & Varies & Varies & $\begin{array}{l}\text { None, must go } \\
\text { to } \\
\text { Machacamarca }\end{array}$ & $\begin{array}{l}\text { None, must go to } \\
\text { Machacamarca }\end{array}$ \\
\hline $\begin{array}{l}\text { Women } \\
\text { leaders }\end{array}$ & $\begin{array}{l}\text { Yes, local } \\
\text { and regional } \\
\text { (CORIDUP) }\end{array}$ & $\begin{array}{l}\text { Yes, local } \\
\text { and regional } \\
\text { (CORIDUP) }\end{array}$ & Yes, only local & Some, only local \\
\hline
\end{tabular}

Produced by the author based on interviews with different actors as well content analysis of various documents. 


\subsubsection{The Huanuni mine: "sangre de minero, semilla de guerrillero"}

The Huanuni mine, located in the city of Oruro (and in the Huanuni municipality which is in close proximity to these communities), is the principal tin mine in Bolivia, and it is among the top five tin producers worldwide (Cantoral, 2017). The depths of the connection among tin (known in Bolivia as Metal del Diablo, the devil's metal), the Huanuni mine, and miner workers have been connected to the broader socio-economic and political life of Bolivia cannot be understated. The phrase "Sangre de minero, semilla de guerrillero" [blood of miner, seed of fighter] alludes to this connection. ${ }^{32}$

After the drop in silver prices near the turn of the $19^{\text {th }}$ century, tin became the primary mineral for export in Bolivia. Between 1904 and 1918, tin represented 50\% to $71 \%$ of Bolivian total exports (Zuazo, n.d). During the 1940s, Simon Patiño, the Bolivian businessman and owner of La Salvadora tin mines (the richest tin deposit in the world) and the Huanuni mine, became one of the wealthiest men in the world. While his wealth gave Patiño the nickname "El Varon del Estaño" [The Lord of Tin], Bolivian tin miners worked in extremely detrimental and exploitative conditions with little or no labor rights and low pay. The average life of a Bolivian miner was estimated to be 30 years, with most of them dying of silicosis, a common disease due to exposure to silica dust (Zuazo, n.d). For these reasons, the Huanuni miners themselves played a central role during the

\footnotetext{
${ }^{32}$ A popular phrase used in Bolivia to describe the vibrant political history of miners. Arbona (2008) and Boudin (2009) also use this phrase to describe that although neoliberal policies in the 1980s destroyed the radical and organized mining labor movements, resulting in the mass migration of miners into the Chapare region of Cochabamba and the city of El Alto, this migration also helped to spread "the seeds of future political movements, including those that would carry Evo [Morales] to the presidency" (Boudin, 2010, n.p).
} 
fight for workers' rights. In 1919, it was the Huanuni miners who organized and won the fight for an eight-hour workday (Gareca, 2006).

Nevertheless, oppressive and exploitative conditions continued. Influenced by an emergent pro-Trotskyist political atmosphere, the city of Huanuni and its miners fostered the creation of the most radical workers' union in Bolivia and Latin America: $L a$ Federacion de Trabajadores Mineros de Bolivia [Federation of Mine Workers of Bolivia, or FSTMB] (2006). In 1946, FSTB produced La Tesis de Pulacayo, considered one of the most important labor documents in Latin America of that time due to its radical and critical analysis of capitalist development and its demand for a workers' revolution (Arbona, 2008). FTSTMB, considered the vanguard of the labor movement, was also a central faction within the Bolivian revolution of 1952 that resulted in agrarian reform (or the promise of land reform) and the nationalization of Bolivian mines, including Huanuni.

During the 1970 s, when tin prices were high, the state was able to neutralize a significant faction of the Huanuni miners by giving them a raise to more than double their previous salaries. The exploitative conditions within the mines did not change, however, and often they got worse. When the international price of tin crashed in 1985, the Bolivian state implemented orthodox neoliberal policies that drove one of the bitterest episodes in Bolivian labor history. The resulting privatization of mines left approximately 20,000 miners unemployed; most of who migrated to Cochabamba to become coca leaf growers and the future political base of Evo Morales. Privatization also led to an increase in mining cooperatives, which proliferated after the neoliberal policy implementation. In 
Oruro, this meant the division of the working class between cooperative miners and the privatized Huanuni miners.

In 2006, a conflict emerged between these two mining labor sectors due to poorly defined working sections at the Posokoni hill where both worked side by side. The Huanuni mine at that time included 700 workers, while the cooperatives involved 4,000 workers. The conflict resulted in 16 people dead from dynamite explosions (what miners usually use during conflicts) as well as the forced nationalization of the Huanuni mine. This forced nationalization meant that the number of waged miners in the Huanuni mine increased from 700 to 4,500 (Perrault, 2014). Equally significant, this resulted in higher production, from 400 tons of mineral extracted per day in 2006 to 1,000 tons in 2010 (2014).

Although mining contamination had started decades if not centuries before, the increased production and lack of concern for the environment resulted in the Huanuni mine becoming a major source of contamination for the nearby communities, rivers and lands beginning in the 1980s and continuing into the present. It is this increase in production that has become a central concern for the nearby communities. The contamination of waters and soils include heavy metals (lead, arsenic, cadmium, iron, and zinc), chemical waste, and other acid runoff such as copajira, or acid water (Perreault, 2014). The mine has two ingenios: Santa Elena, next to the mine, with a capacity of 1200 metric tons/day and the Machacamarca ingenio that produces $200 \mathrm{t} /$ day (Perreault, 2014). ${ }^{33}$ However, neither of these ingenios has working tailing dams to contain mining

\footnotetext{
${ }^{33}$ These are the locations where minerals are separated and melted. If they have a tailing dam, then they store and recycle the water used for these processes. If not, toxic waters are dumped straight into the nearby rivers.
} 
waste (Machacamarca has a tailing dam that has reached capacity). This means that untreated water and sediments enter directly into the nearby San Juan de Sora Sora, Santa Fe and Huanuni rivers that then carry the contaminated waters to the communities downstream and to Lake Poopó (Sanchez, 2009). ${ }^{34}$

\section{2. Data and methods}

\subsubsection{Focused multi-sited ethnography}

The type of ethnography I used has two characteristics: it is focused and it is multi-sited. Focused ethnography (also known as short-term ethnography) is an emerging approach, not in opposition to, but complementary to and a subtype of conventional longterm ethnography. Short-term fieldwork and "forms of intensity that lead to deep and valid ways of knowing" characterizes focused-ethnography (Pink \& Morgan, 2013, p. 1). ${ }^{35}$ For this type of ethnography, the difference between strangeness and alterity is fundamental (Knoblauch, 2005). Strangeness refers to unfamiliarity with specific situations and with the general culture. Alterity, on the other hand, refers to a different actor (the ethnographer) who is already familiar with the context and has a sense of common knowledge of a local place and its people. This allows the ethnographer to identify commonalities as well as differences before starting fieldwork (2005). In this

\footnotetext{
${ }^{34}$ The community of Alantañita is also affected by the contamination brought by the Desaguadero river that eventually reaches into Lake Poopó.

${ }^{35}$ In focused ethnography, the ethnographer seeks from the very beginning to be involved and to engage participants in the project by clearly explaining his/her intentions (Pink \& Morgan, 2013). Focused ethnography also requires an intense ethnography-theory dialogue that "involves continually bringing theoretical questions into dialogue with the ethnography" (2013, p. 5). Post-fieldwork engagement with the material must also be intense. Coding is supplemented with sequential analysis (Knoblauch, 2005). For this type on intensity, Pink and Morgan recommend the use of visual materials (photos, videos), not only for rich visual data but for these materials to re-engage with other written materials and with the context (2013). This of course, requires an "ongoing process of informed consent" $(2013$, p. 7).
} 
matter, I did have an advantage with familiarity since I am from Bolivia and my grandparents were immigrants from the rural communities of Oruro. I had also visited Oruro before as part of family trips. A representative of CEPA, during a phone conversation before my field visit, expressed the following: "you are Bolivian like us; if we support foreigners, of course we will support you as well."

A multi-sited component allows the researcher multiple sites of observation and participation that emphasize associations, connections and comparative differences among sites (Marcus, 1995). Therefore, a multi-sited ethnography aims to construct within a locale a sense of the system that is often attuned "for what goes on in another related locale, or other locales" (1995, p. 110). A multi-sited ethnography challenges dichotomies such as local-global, as well as reductions of local realities to macro processes of capitalist political economy. It builds on research that recognizes that cultural constructions are produced, reproduced, and conditioned by time-space dynamics (1995). Therefore, strategies of "following connections, associations and putative relationships are thus the very heart of designing multi-sited ethnographic research" (1995, p. 97).

For these reasons, I conducted a focused multi-sited ethnography in two municipalities within the Poopó basin located in Oruro, Bolivia. ${ }^{36}$ This ethnographic approach consisted of three components for data collection: semi-structured interviews, which provided the core of data analysis, followed by participant observation and focus

\footnotetext{
${ }^{36}$ To refresh, Oruro is one of nine departments of Bolivia. The city of Oruro is the biggest town within the Oruro department. The Oruro department is divided in municipalities and these municipalities have cities with the same names: Machacamarca and Poopó for example, are important towns within the Machacamarca and Poopó municipalities. Then there is the Poopó Basin that includes all of the municipalities and communities mentioned in this research. Poopó is also the name of Bolivia's second largest lake.
} 
groups. The combination of these three components allowed me to collect and complement information about the socio-cultural and political context of the Andes, and the life stories that participants shared with me during the interviews. The combination of three methods also helped my research with the methodological intensity that focused ethnographies require.

\subsubsection{Fieldwork preparation}

Prior to fieldwork, I initiated contact via email with a formal letter and then via telephone with two organizations in Oruro: CORIDUP (the Desaguadero River, Uru and Poopó Lakes Defense Coordinator) and CEPA (the Center for Ecology and Andean Communities). CORIDUP is a grassroots organization that represents more than 80 communities from four municipalities (Machacamarca, Poopó, Huanuni and El Choro) within the Poopó basin. This organization was created in 2006 as a response to the effects of mining contamination in this region and has been active ever since in documenting the socio-environmental effects of mining as well as in organizing protests demanding better environmental regulations (Horowitz \& Watts, 2016). CORIDUP was also the leading organization involved in the creation of Supreme Decree 0335 (SD 0335) that declares the Poopó basin an environmental emergency zone (described in detail in Part II). CEPA is a local NGO in Oruro, Bolivia whose mission is centered towards strengthening social movements, particularly those related to environmental justice and grassroots organizing capable of generating intercultural dialogue and participation. CEPA also supports actions to revalorize indigenous identities and knowledge. CEPA collaborates and offers different types of support to CORIDUP and other grassroots organizations. This support 
includes provision of spaces for meetings, workshops and trainings (Sanchez, personal communication, Novermber 20,2017). CEPA was created in the 1990s and it is perhaps among the first organizations in Bolivia that focused on socio-environmental issues, particularly mining contamination.

CORIDUP and CEPA connected me with Don Miguel, age 67, a former CORIDUP president and vice president and leader of the Kochi Piacala community. ${ }^{37}$ Don Miguel migrated and moved to the city of Oruro more than 30 years ago. However, like many other migrants from rural communities, he has kept close contact with his community and he still has a parcel of land there. In 2006, Don Miguel became CORIDUP president and vice-president representing his community. Don Miguel helped me with initial contacts as well as scheduling meetings with key community actors in the Machacamarca municipality. Don Miguel was really supportive and since our first conversation, he referred to me as hermana. In the context of Bolivia, hermana (sister) is used to signify likeness and trust. The use of hermana (or hermano for men) among indigenous campesinx communities is particularly important to highlight the interrelatedness (by kinship or social links) between individuals. The used of hermana, however, indicates respect and also fondness, trust and openness to another person, particularly outsiders. As Tania, 28, a member of the Wasi Pacha collective explained: In the communities people don't call anyone hermana, they instead try to make a rift when an outsider comes...they will always ask first for your

\footnotetext{
${ }^{37}$ For confidentiality purposes, I use pseudonyms for all the participants in this study. Moreover, I used Don and Doña (Mr. and Mrs.), which denotes respect for older people and also to refer to participants as other participants refer to them. While some participants refer to Don Miguel as hermano Miguel (signaling familiarity and trust), others refer to him as "Don" or as compañero [comrade]. Don/Doña are common and standard words to indicate respect, and that is why I use these words.
} 
degree if they know you are an outsider, but if they are able to relate to you in an emotional and trustworthy manner, then they will use the word hermana as a signal that they trust you and they want to know you. The word has a lot to do with the relationship an outsider has with the community. In April 2018, before I began fieldwork in the municipality of Poopó, Tania, 28, introduced me to Doña Victoria, 49, from the Poopó municipality, who is a recognized community leader of Quellia, Poopó and a CORIDUP member. Similar to Don Miguel, Doña Victoria was very supportive of my work and we referred to each other as hermanas. ${ }^{38}$ She also was the key participant in Poopó that helped me to contact participants and key actors in this municipality.

I devoted the first four weeks of fieldwork in Bolivia to building relationships, and getting familiar with the context and the people in CORIDUP, CEPA and in the municipalities. During this time, I coordinated logistical arrangements such as a place to stay and locations to conduct semi-structured interviews. I also devoted this time to making informal conversations with community members, mapping key community actors for further interviews, and making connections with members of the Wasi Pacha collective, a local activist group in Oruro that works on mining contamination and other issues. This time allowed me to pilot test the interview guides with the help of Don Miguel to make sure I use colloquial and appropriate language. The same process happened before I started data collection in the Poopó municipality. I spent the last two

\footnotetext{
${ }^{38}$ Not everyone however, referred to me as hermana. Other participants referred to me as licenciada [someone with a bachelor degree], which has two meanings: respect and recognition for the value of education and also distance and mistrust. As Tania, 28, explained, comunarixs might call outsiders licenciada (o) to emphasis the outsider position and their lack of trust towards them.
} 
weeks of April 2018 building these relationships in Poopó with the help of Doña Victoria.

\subsubsection{Communities for fieldwork}

The second week I arrived in Bolivia I met with Don Miguel, and I explained to him my interest in carrying out a focused multi-sited ethnography, which emerges from the understanding that indigenous communities in Oruro share many similarities and differences. Particularly, I wanted to explore the conflicts between miners and campesinxs within communities. ${ }^{39}$ Instead of interviewing people from a community affected by mining contamination in each municipality, Don Miguel suggested that I interview people from four communities: two communities in Machacamarca and two in Poopó ${ }^{40}$ After our discussion, and also with help from CEPA, four indigenouscampesinx communities that are affected by mining contamination were identified to be part of this study: Alantañita and Kochi Piacala in Machacamarca, and Quellia and

\footnotetext{
${ }^{39}$ Instead of using the English word peasant/peasants I used the Spanish word campesinx/campesinxs to resemble closer how participants refer to themselves. Campesinx also means del campo (from the countryside) and this better reflects how participants explain their indigeneity (see part II for a more detailed description of this topic). The ' $x$ ' is used to make the language more inclusive (in terms of gender), especially when referring to groups as in campesinxs.

${ }^{40}$ Don Miguel suggested four rather than two communities (as I originally proposed) due to several reasons. First, many of these communities have experienced an intense rural-urban migration, where communities have become almost ghost towns. Second, November was the start of the rainy reason, making access to some communities almost impossible. Third, we were close to Christmas, New Year and carnival holidays, which in Bolivia mean celebration planning and therefore people being unwilling or unable to participate in research. I was skeptical at first, but Don Miguel was right. The combination of all these factors made really it difficult to interview people and to travel to the communities. These national holidays also coincided with local and traditional holidays, which local people devoted a lot of time to prepare for these celebrations. Many of the potential participants I recruited agreed and seemed to support my research. We would set a time and a date to meet. However, they would not show up, or they would call me last minute to re-schedule our meetings. Considering that many people that I interviewed were also involved in community organizing, it is understandable that their time was very limited. On top of this, the constant protests, rallies and strikes (particularly from the public transportation sector) added to the difficulty of meeting with participants.
} 
Puñaka in Poopó. ${ }^{41}$ Table 3 shows some of the socio-economic characteristics of these municipalities: they have predominantly indigenous campesinxs populations, with a significant percentage of people engaged in agriculture and/or subsistence farming, and livestock. They are part of CORIDUP because they are heavily affected by mining contamination. They also share important differential factors. In the Poopó municipality, tensions erupt sometimes due to the internal community division between those working for the mines (particularly in the Poopó cooperative mine) and those working in agriculture. In Machacamarca such tensions seem minimal. The data in Table 3 is at the municipality level only, which might obscure differences between communities within a same municipality.

\footnotetext{
${ }^{41}$ The New Bolivian Constitution uses the term indígena originario campesino (indigenous, originary peasant) to refer to indigenous communities and peoples (see the literature discussion on this topic). For this study I will use the term indigenous campesinx because this is how participants refer to their communities.
} 
Table 3. Socio-economic characteristics of the municipalities for fieldwork

\begin{tabular}{|c|c|c|c|c|c|}
\hline & Bolivia & Oruro & Poopó & Machacamarca & $\begin{array}{c}\text { El } \\
\text { Choro }^{42}\end{array}$ \\
\hline Population & $10,059.856$ & 494,587 & 7,587 & 4,820 & 8,725 \\
\hline Ethnicity & Multicultural & $\begin{array}{c}\text { Quechua, } \\
\text { Aymara, } \\
\text { Urus }\end{array}$ & $\begin{array}{c}\text { Quechua, } \\
\text { Urus }\end{array}$ & Quechua & Quechua \\
\hline $\begin{array}{l}\text { Living in } \\
\text { poverty }(\%)\end{array}$ & 44.9 & 47 & 52.9 & 45.2 & 97.9 \\
\hline $\begin{array}{l}\text { Literacy } \\
(\%)\end{array}$ & 94.9 & 96 & 92.3 & 94.3 & 95.5 \\
\hline $\begin{array}{l}\text { Agricultural } \\
\text { workers } \\
(\%)\end{array}$ & 27.2 & 29 & 41.9 & 31.1 & 72.8 \\
\hline $\begin{array}{l}\text { Piped water } \\
\text { access }(\%)\end{array}$ & 68.3 & 64 & 53.8 & 61 & 0.8 \\
\hline $\begin{array}{l}\text { Water } \\
\text { coverage } \\
(\%)\end{array}$ & 80.8 & 78.9 & 79.8 & 76 & 3.0 \\
\hline
\end{tabular}

Adapted from the National Institute of Statistics (INE. Bolivia 2012 national census)

\subsection{Data collection}

This study uses a multi-method approach consisting of a) semi-structured interviews and b) participant observation, and c) focus groups. Semi-structured interviews were the principal source of data collection while participant observation and focus groups were complementary to it. This means that participant observation and focus groups helped to triangulate the information from semi-structured interviews and they also helped to provide the context and background to interpret the data from semistructured interviews. The combination of multiple methods and data sources is highly

\footnotetext{
42 The Kochi Piacala community is located within the administrative jurisdiction of El Choro municipality. However, because of geographic proximity, this community has most of its socio-economic relations built in the town and municipality of Machacamarca. For this reason, Kochi Piacala is sometimes considered to be part of Machacamarca. Kochi Piacala and Alantañita share similar experiences with mining contamination.
} 
recommended for focused ethnographies where data intensity from multiple sources is necessary. Moreover, multiple data sources from different actors allow for the triangulation of key findings and enhancing the validity of the results. Within the semistructured interviews I also included a couple of closed-ended questions at the beginning of each interview (as well as in focus groups) to establish personal attributes (age, marital status, level of education, religious affiliation), household characteristics (toilet facilities, cooking fuel), and women's social status (ownership of household and land, decision making within household). Table 4 shows the participants' demographic characteristics.

\subsubsection{Semi-structured interviews}

The major strength of semi-structured interviews is the combination of depth in conversations and "reliable, comparable qualitative data" (Cohen \& Crabtree, n.p) that results from a set of pre-determined questions. For the focused ethnographies, this method is particularly relevant since the time frame might not allow for more than one chance to interview participants. A pre-determined set of questions also assures that relevant questions are examined. Semi-structured interviews included a total of 27 participants with four subsets of interviews based on participants' roles and positions related to their communities. These subsets of interviews are:

1) Semi-structured interviews with women leaders: At the community level, I conducted semi-structured interviews with 16 community women leaders, all adult women (18 years or older). From the vantage point of this study, there were two groups of indigenous women that were included in this sample: 
1.1) Women leaders ( $\mathrm{n}=13$ total) from the four communities of this study who are impacted by mining contamination, which includes women with diverse backgrounds, such as women working within subsistence economies; women who work at home, women immigrants and/or all these three scenarios. ${ }^{43}$ Leadership positions also varied, from finance secretaries to Mama T'allas (highest female indigenous authority)

1.2) Women leaders from CORIDUP ( $\mathrm{n}=3$ total) who were not members of the four communities from this study. ${ }^{44}$

2) Semi-structured interviews with key community actors ( $\mathrm{n}=5$ total): To contextualize and triangulate the information provided by community women leaders, I conducted semi-structured interviews with key community actors (all men) such as local authorities known as Tata Mallkus (the Quechua term for male leaders), a Tata corregidor (indigenous Mayor), and leaders from CORIDUP. These key community actors were identified with the help of CORIDUP and CEPA prior to fieldwork as well as during interviews with community members. These interviews shed light on perceptions about the impact of mining extraction on women's lives, as well as how communities organize around mining extraction issues.

3) Semi-structured interviews with CEPA ( $n=3$ total): At the local level, I interviewed members of the Center for Ecology and Andean People (CEPA), a local NGO centered on environmental justice issues. I was particularly interested in how CEPA articulated its

\footnotetext{
${ }^{43}$ My original plan was to have two separate groups of women: regular community members and women who are community leaders. I realized however, that due to an inclusive mechanism of leadership participation among these communities, all women who I interviewed (except for one of them) had had a community leadership role. Therefore, I established leadership as a main category.

${ }^{44}$ My original proposal included women working in the mining industry (known as palliris). However, the great majority of women in these communities do not work in mining because their communities are not located close enough to the mines and many of them do not live in their communities anymore.
} 
role and its impact on community grassroots organizing. Moreover, I was also interested in understanding the position CEPA has with respect to the government's policies towards neo-extractivism.

4) Semi-structured interviews with government representatives ( $\mathrm{n}=3$ total): The last set of semi-structured interviews were with three representatives from the local government, pertaining to the Ministry of Rural Development and Territories (MDRyT), and the Ministry of Environment and Water (MMAyA). I was interested in how government officials articulate the contradictions between the MAS government's pro-environment rhetoric and its extractive economic policies. ${ }^{45}$

\footnotetext{
${ }^{45}$ Although President Morales and Vice President Garcia Linera have explained such contradictions, less is known about other government officials. I am also interested in their perspectives about neo-extractivism's effects on indigenous women. It is curious for example, that Elisa Vega Sillo, a member of Bolivia's Vice Ministry of Decolonization, usually refers to the oppression of indigenous women because of colonialism resting on two axes: racism and patriarchy (Vega, 2013). Yet Vega makes no mention about the role of capitalism and its intrinsic connection with colonial rule and the axes she mentions.
} 
Table 4. Demographic characteristics of participants.

\begin{tabular}{|c|c|c|c|c|c|c|}
\hline \multirow[b]{2}{*}{ Variable } & & \multirow{2}{*}{$\frac{\text { MACHACAMARCA }}{n}$} & \multirow{2}{*}{$\frac{\text { POOPO }}{\mathrm{n}}$} & \multirow{2}{*}{$\begin{array}{c}\text { OTHER } \\
\mathbf{n}\end{array}$} & \multicolumn{2}{|c|}{ TOTAL } \\
\hline & & & & & $\mathbf{N}$ & $\%$ \\
\hline \multirow{3}{*}{ Gender } & Women & 7 & 6 & 4 & 17 & 63 \\
\hline & Men & 1 & 3 & 6 & 10 & 37 \\
\hline & Total & 8 & 9 & 10 & 27 & 100 \\
\hline \multirow[t]{3}{*}{ Age } & $25-45$ & 2 & 2 & 2 & 6 & 22 \\
\hline & 46-65 & 5 & 5 & 6 & 16 & 60 \\
\hline & 66-more & 3 & 1 & 1 & 5 & 18 \\
\hline \multirow[t]{2}{*}{ Indigenous } & Yes & 8 & 9 & 5 & 22 & 89 \\
\hline & No & 0 & 0 & 5 & 5 & 11 \\
\hline \multirow[t]{2}{*}{ Religion } & Catholic & 6 & 4 & 9 & 19 & 70 \\
\hline & Evangelic & 2 & 5 & 1 & 8 & 30 \\
\hline \multirow[t]{2}{*}{ Lives in community } & Yes & 5 & 0 & 2 & 7 & 26 \\
\hline & No & 3 & 9 & 8 & 20 & 74 \\
\hline \multirow[t]{2}{*}{ Land in community } & Yes & 7 & 9 & 4 & 20 & 74 \\
\hline & No & 1 & 0 & 6 & 7 & 26 \\
\hline \multicolumn{7}{|c|}{ For Women leaders only (16)* } \\
\hline \multirow[t]{3}{*}{ Marital Status } & $\begin{array}{r}\text { Married/ } \\
\text { union }\end{array}$ & 4 & 4 & 1 & 9 & 56 \\
\hline & Single & 2 & 1 & 1 & 4 & 25 \\
\hline & Other & 1 & 1 & 1 & 3 & 19 \\
\hline \multirow[t]{3}{*}{ Education } & Primary & 6 & 2 & 1 & 9 & 56 \\
\hline & Secondary & 1 & 3 & 1 & 5 & 31 \\
\hline & Higher & 0 & 1 & 1 & 2 & 12 \\
\hline \multirow[t]{2}{*}{ Works } & Yes & 7 & 5 & 2 & 14 & 88 \\
\hline & No & 0 & 1 & 1 & 2 & 12 \\
\hline \multirow[t]{3}{*}{ Where } & Agriculture & 3 & 1 & & 4 & 25 \\
\hline & $\begin{array}{r}\text { Informal } \\
\text { Sector }\end{array}$ & 3 & 2 & 2 & 7 & 44 \\
\hline & lother & 1 & 3 & 1 & 5 & 29 \\
\hline \multirow[t]{2}{*}{ Access to water } & Yes & 0 & 0 & 1 & 1 & 6 \\
\hline & No & 7 & 6 & 2 & 15 & 94 \\
\hline \multirow[t]{4}{*}{ By Group } & $\begin{array}{c}\text { Women } \\
\text { Leaders }\end{array}$ & 7 & 6 & 3 & 16 & 52 \\
\hline & Key Actors & 1 & 3 & 1 & 5 & 19 \\
\hline & $\begin{array}{r}N G O \\
(C E P A)\end{array}$ & - & - & - & 3 & 11 \\
\hline & Government & - & - & - & 3 & 11 \\
\hline
\end{tabular}

Table 4 shows that the majority of participants were women (63\%) between 46 65 years of age. In both municipalities all of the participants self-identified as indigenous. Half of other participants who were not part of these municipalities, such as members of CEPA, also self-identified as indigenous. Following general trends in Bolivia, the majority of these participants are Catholic, with a minority but not insignificant 
population of evangelical followers, particularly in the Poopó municipality. ${ }^{46}$ Only $26 \%$ of participants live in their communities, with the majority living somewhere else. In contrast, $74 \%$ of participants still have a land parcel in their communities. This is referred as la doble residencia [double residency], a pattern in which people from the communities live usually in a nearby town/city but go back to their communities during the weekends to take care of their lands (I will explain this in depth in Part II). It is also important to highlight that none of the participants have access to clean water in their communities.

\subsubsection{Participant observation}

As its name states, participant observation refers to the dual position a researcher acquires as an insider as well as an observant of the place and society to be explored. Participant observation is a central source of ethnographic data, where there is a continuous intersubjectivity between subjects and researcher based on correspondence, which aims to answer what is happening with "interventions, questions and responses of our own" (Ingold, 2014, p 389). In other words, there are ongoing conversations between the researcher and participants to clarify emerging questions and situations. In this sense,

\footnotetext{
${ }^{46}$ Religion is outside the scope of this research. Nevertheless, it is important to highlight the relevance of this topic for further research. Oruro is not a cosmopolitan center nor Oruro is a big city in Bolivia. Participants are from rural communities that are difficult to access because lack of roads. I was surprised that around $30 \%$ of participants were evangelicals, yet this has become a common trend in the region. The evangelical movement in Latin America has growth significantly since the 1980s, and they are getting increasingly involved in politics with right-wing parties, therefore giving a new meaning to this conflicting relationship. Evangelicals have conservative views, especially in regards to gender and sexuality, and they also have something that right-wing parties do not: the capacity to connect with regular working class people. Therefore, Evangelicals fuel conservative ideologies (and vice versa) that then are immersed in politics to recruit followers for religious and political purposes. A prime example of this trend is Brazil, where 90 members of its congress are evangelicals and the Mayor of Rio de Janerio is an evangelical bishop. In the context of this study, evangelical participants were less likely to keep traditional practices such as rituals to Pachamama, since for them Pachamama is not a god. This shows the urgency of further research on the evangelical movement in Latin America (Corrales, 2018).
} 
correspondence is never given, nor it is static, or achieved, but rather, it is dialectical and is always a process on the making (2014). Participant observation therefore is not just a description of peoples and places, but it is an ongoing and dynamic correspondence between the researcher and the very people "with whom we learn or among whom we study" (2014, p. 390).

My original plan for participant observation was a systematic plan where I would visit and stay in each of the communities for this study for at least three weeks and then go back and forth to interview participants. For the same reasons of community identification (see footnote 38) I was unable to do this. Therefore, participant observations became a supplementary and often informal source of information. This means that although I had a tentative schedule to visit communities and attend meetings, all of this was subject to participants' availability to meet, which as explained in footnote 38, was very difficult. ${ }^{47}$ Participant observations, however, even in this informal and less structured setting, offered important and crucial context and data for this study.

Participant observation consisted of visits, stays at homes, workshops, ceremonies, and community meetings in both municipalities as well as in the city of Oruro. I participated in five meetings of CORIDUP, including a trip to La Paz where CORIDUP met with government officials from different ministries. CORIDUP meets the first Friday of each month in the city of Oruro at CEPA's office and CEPA representatives help moderate the meetings. Moreover, I also observed and participated in

\footnotetext{
${ }^{47}$ Many indigenous communities in the Andes also have their own protocols to carry on research in their communities. A formal presentation to the community and its leaders before data collection is expected. Other researchers and NGOs in this area recommended me, for example, to first talk with a key community actor before visiting the communities. it took me almost four weeks to finally meet with my first community actor.
} 
activities and events in the nearby towns of Machacamarca and Poopó. These are urban towns near the communities of this study and important focal points for them for several reasons. First, many people from the communities of this study live in one of these two towns. Second, community members travel constantly to these two towns to buy water, food, and goods, and/or to sell their products and to have their monthly community meetings, which last from three to up to eight hours. Third, in the case of Poopó, many community members come to this urban town everyday to work in the Poopó mining cooperative. During these activities I was able to carry on informal and everyday conversations with community members (not audio recorded), as well as take photographs and detailed fieldnotes about people's interactions, body languages, groups dynamics and any information and descriptions that would help me contextualize these activities.

To do the semi-structured interviews, I went to some of the participants' houses and this allowed me to observe the local context in which people live. In December 2017 I stayed for two weeks in the Kochi Piacala community with Doña Paula, 69, who was kind to offered me a place to stay and allowed me to help her with daily activities such as collecting water, cooking, and grazing her animals (cows and sheep, with the help of two shepherd dogs). This experience and all my fieldwork observations deepened and changed my vision about the effects of mining contamination and the threat that mining represents to the reproduction of social life among indigenous campesinx communities. 


\subsubsection{Focus groups}

The main strength of focus groups relies on the "purposeful use of interaction to generate data" (McLafferty, 2004, p. 187). This emphasis on interactions allows the researcher to observe and analyze how participants relate to and influence each other to create everyday knowledge (2004). Focus groups are particularly useful to gather information on people's attitudes, beliefs, experiences and understandings on a given topic (2004). As Morgan (1996) and McLafferty (2004) point out, focus groups might not be as strong as participant observation for data gathering on context and settings, nor as strong as semi-structured interviews in providing deep understandings of individual perceptions. Nevertheless, they provide a middle ground that combines the goals of these two techniques. Semi-structured interviews provide greater depth while focus groups provide greater breath (Morgan, 1996).

To complement data collection from semi-structured interviews and participant observation, I conducted two focus groups with two environmental collective: Wasi Pacha (house of earth), and Las Ramonas (in reference to the Zapatista leader Ramona). The majority of the Wasi Pacha members are women and Las Ramonas is a women-only collective. Their age range is between 25-38 years of age and all of them live in the cities of Oruro and Cochabamba. They are all educated with at least a bachelor's degree, and for Wasi Pacha, the majority self-identifies as indigenous. A turning point for their activism was the TIPNIS conflict and also their participation in environmental workshops that addressed local issues, such as mining contamination in Oruro.

These two collectives work on a different array of issues, including revitalization 
of ancestral practices and knowledge, domestic violence, food sovereignty, and neoextractivism. Moreover, although they are located in different cities (Oruro and Cochabamba) they do significant collaborative work on mining contamination in the rural areas of Oruro. Particularly pertaining to Wasi Pacha, many of its members are rural immigrants whose families moved to the city of Oruro. Although Wasi Pacha's members did not grow up in the communities, or spent just a few years living in rural areas, they keep close ties to them. They might have lands, and/or they have family members, especially parents and grandparents who still live in the communities. They are also part of an emerging movement of indigenous migrants in the cities interested in cultural revitalization and ancestral practices that motivate people to reconnect with their communities of origins. The other collective, Las Ramonas, while not having direct kin connections with the communities, emphasized a deep sense of gender and ethnic solidarity. According to them, their solidarity with indigenous communities, and particularly indigenous women, became stronger after they participated in support of TIPNIS communities, and also after the news that Lake Poopó had dried out in 2016. Las Ramonas, which are located in Cochabamba, Bolivia (eight hours by bus from Oruro) produced the documentary "Yakurayku Puriqkuna" (walking in the water) that shows the environmental effects of the drying out of Lake Poopó on indigenous campesinx women in Oruro.

These focus groups helped me to explore how younger generations, especially women, are organizing and making links between the often separated urban-rural localities to address and confront the effects of mining contamination. Moreover, these 
focus groups allowed me to explore how indigenous and non-indigenous people living in urban areas understand the role of a self-proclaimed indigenist state on their lives and on the surrounding communities.

\subsubsection{Sampling strategy and participant recruitment}

For semi-structured interviews with community women leaders I used a purposive and quota sampling approach. Since the criteria for community member participants included adult women within each community, I started by building a close relationship with two key actors: Don Miguel for Machacamarca, and Doña Victoria for Poopó. CEPA introduced me to Don Miguel and Wasi Pacha introduced me to Doña Victoria. These actors are both well known and respected leaders within their communities, and both have been active in anti-mining struggles in this region. They both gave me phone numbers and/or introduced me to other community members. Before recruiting participants, I presented the goals and scopes of this study to each community during its monthly meeting to get a general consent from community leaders, as well as for potential participants to know me and to know the scope of this research. ${ }^{48}$

For individual interviews, I introduced myself with a verbal script to identify potential participants who were able and willing to participate (see the appendix for these documents). The number of participants was based on saturation as well as availability of participants. For key community actors, I used snowball sampling, also known as

\footnotetext{
${ }^{48}$ I was unable to offer this presentation in Quellia. The community postponed its meeting twice and the next meeting was scheduled after the date I left Bolivia. Nevertheless, I asked two indigenous leaders of Quellia and they told me I could go ahead with the interviews. In Puñaka, I explained the goals and scope of this study to the indigenous leader (Tata Mallku) of the Puñaka Allyu before the meeting. Due to time constraints, he asked me not to present my goals during the meeting since he did not find anything concerning and told me I could go ahead with the interviews as well.
} 
referral sampling (CIRT, 2016). I identified these key actors through the semi-structured interviews with community members. I also asked CEPA and CORIDUP to help me map these actors.

For interviews with members of CEPA, CORIDUP women leaders, and government officials, I used purposive and convenience sampling. The goal of these interviews was not to reach saturation, but rather to triangulate the data from the interviews with community women leaders and to gather data from the specific positions these participants have, which is the base of purposive sampling (QAQM, 2016). For this reason, I conducted five interviews with key actors (all male community leaders), three interviews with CORIDUP women leaders, three interviews with members of CEPA, and three interviews with government officials. Because interviews with government officials were extremely difficult to obtain, I relied on convenience sampling for these. I sent formal letters (hard copies as well as emails) to different ministries; I called them and visited their office, but none of them replied back. I was lucky to obtain some phone numbers during a CORIDUP meeting with government officials from MDRyT and MMAyA and that is how I was able to obtain these interviews. ${ }^{49}$

For focus groups, participants were identified via purposive and snowball sampling. I met Mario, one of the founders of Wasi Pacha, during a community meeting to install solar panels in his grandparents' community, Kochi Piacala. He explained the mission and work of Wasi Pacha and invited me to one of its events where I met the

\footnotetext{
${ }^{49}$ I was able to contact and schedule a meeting with a government official from MMAyA at the national level. However, he stopped his participation when I asked if he was a member of MAS (the political party of Evo Morales). He got really upset, (and) asked, "is this for an academic research? We are able to answer only technical questions," and just stopped answering my questions and left. Another government official from MDRyT at the national level told me he was not sure if he had permission to talk about this topic and he stopped replying to my messages.
} 
other Wasi Pacha founders who participated in the focus groups. Wasi Pacha connected me with Holga, 32, from Las Ramonas. Holga used to lived and worked in Oruro, doing work around the Poopó municipality. I contacted Holga, and after explaining the goals of this study she helped me organize the focus group.

\subsubsection{Recording and transcriptions}

All interviews and focus groups were recorded and transcribed in Spanish, and only the excerpts used in this dissertation were translated into English. I explained to participants the importance of confidentiality, and that even though the interviews were recorded, no identifiers, such as names, or addresses, were included (see Appendix for informed consent documents). Each interview was assigned a random set of numbers and a pseudonym with no connection to participants. I also explained to participants the importance of recordings for accurate representations of their perspectives. Participants had the option to not have the interviews recorded or to stop recording at any time during the interview if they felt uncomfortable or alienated. All this information was included in the informed consent form (see appendix).

\section{4. Data analysis}

To analyze the data gathered, I conducted directed content analysis using a deductive approach, since focused ethnography requires an ongoing ethnography-theory dialogue that "involves continually bringing theoretical questions into dialog with the ethnography” (Pink \& Morgan, 2013, p. 5). As Thomas argues, there are significant differences between inductive and deductive analysis. The former uses primarily detailed 
readings from the raw data to create concepts, themes and models while the latter uses raw data to test whether prior assumptions, theories and hypotheses are valid. According to Hsieh \& Shannon (2005), directed content analysis might be categorized as a deductive approach since it is anchored in theory to test hypotheses as well as to validate the relevance of a theoretical framework (2005). While data analysis for this study was anchored in a deductive approach, in practice, I used both methods since prior research on the effects of neo-extractivism and indigenous women is limited, and this research therefore is more exploratory of this topic. To systematize the process of coding and analysis, I used Dedoose qualitative software, a web application for qualitative and mixed methods research.

Using a deductive approach, I identified key concepts, themes and variables for initial categories based on my theoretical framework and literature review. Three primary root codes or main categories were created in relationship to the three research questions: effects of neo-extractivism, the relationship of the state to neo-extractivism, and women's resistance. These root codes guided the questions in the semi-structured interviews and focus groups. After the classification of data into these root codes, using a mix of deductive and inductive approaches, I then identified child codes (or sub codes or categories) within each root code using Dedoose (see Table 5). Remaining data that was not classified into primary root or child codes remained open, with the intention of allowing data to suggest emerging themes that were relevant for the research questions. Once coding for primary root and child codes was finished, I then analyzed this open data with an inductive approach to condense extensive and wide-ranging raw textual data. 
This open data was coded into secondary root codes that developed from the raw data into a framework that contained emerging themes and processes (Thomas, 2006).

Table 5. Root codes and child codes

\begin{tabular}{ccccccc}
\hline \hline $\begin{array}{c}\text { Primary } \\
\text { root codes }\end{array}$ & $\begin{array}{c}\text { Effects of Neo- } \\
\text { extractivism }\end{array}$ & \multicolumn{2}{c}{$\begin{array}{c}\text { Neo-extractivism and the } \\
\text { state }\end{array}$} & Women's resistance \\
\hline \hline Child & Water & Displacement & Corruption & $\begin{array}{c}\text { Local } \\
\text { management } \\
\text { capacity }\end{array}$ & Leadership & Consciousness \\
codes & Migration & Deceiving & Co-optation & $\begin{array}{c}\text { Internal } \\
\text { conflict }\end{array}$ & $\begin{array}{c}\text { Confronting } \\
\text { power }\end{array}$ & $\begin{array}{c}\text { Urban-rural } \\
\text { connections }\end{array}$ \\
& & & $\begin{array}{c}\text { Positive } \\
\text { aspects of } \\
\text { MAS }\end{array}$ & Divisions & & \\
\hline $\begin{array}{l}\text { Secondary } \\
\text { root codes }\end{array}$ & $\begin{array}{c}\text { Animal } \\
\text { relations }\end{array}$ & Local context & $\begin{array}{c}\text { Class } \\
\text { discrim. } \\
\text { Party } \\
\text { affiliation }\end{array}$ & $\begin{array}{c}\text { Ethnic } \\
\text { inclusion }\end{array}$ & Indigeneity & $\begin{array}{c}\text { Development } \\
\text { and Sumaq } \\
\text { Qamaña }\end{array}$ \\
\hline
\end{tabular}

Using Dedoose descriptors I organized all data based on the group it represented. I use arbitrary numbers for this group classification; therefore, interview data from all women from the Poopó municipality was placed within Group 1. Group 2 contained all interview data of women from the Machacamarca municipality. Group 3 contained all data of CORIDUP women leaders, and so on. This organization into groups helped me to identify which codes were more or less prevalent within and between groups, which was particularly useful for the triangulation of data. This helped compare and contrast the relevance of themes for each municipality as well as for each group. Once all data was coded into primary and secondary root and child codes, the ones that had similar or redundant information were merged into thematic categories for data findings. In this matter, numerous codes were transformed into a brief, summary format to establish clear 
links between the research objectives and the findings derived from the raw data.

\subsubsection{Semi-structured interviews}

As explained above, the preliminary coding categories that guided the semi structured interviews emerged from the theoretical framework, analysis of the literature review, as well as analysis of relevant documents from CEPA and CORIDUP.

Documents and literature were reviewed with the objective of determining what were the most recurrent topics on this issue. Some of the child codes were pre-determined based on this (deductive) approach while others were determined based on the data collected (inductive).

The revision of documents helped me to identify those topics that were underexplored (such as the social effects of mining contamination on indigenous women and their communities). Moreover, within each root and child code, I searched for alternative or contradictory or complementary positions. I followed this process for each of the semi-structured interviews in both municipalities (interviews with community women leaders, and key community actors) as well as with interviews with government officials and members of CEPA. Once this process was finished, I charted the categories into a matrix or central framework (visual hand-written map) as suggested by Gale et al. (2013). Charting that includes a summary of each root code allowed me to identify commonalities and contradictions between codes and categories and from different actors (community, key actors, government, etc.). This comparison helped to triangulate the data and to validate and give rigor to the findings. One thing important to highlight is that although this study is multi-sited, I did not find substantial differences between 
municipalities, except on internal community divisions between miners and campesinxs, which were more prominent in the Poopó municipality.

The closed-ended questions of the semi-structured interviews were placed on an Excel list to create a table containing relevant background and demographic information about participants: ages, number and percentages of married individuals, level of education, religious affiliation, and access to water, among others.

\subsubsection{Fieldnotes}

Fieldnotes are an essential part of ethnography since this is where events, moments and reflections turn into accounts that then can be further analyzed to find and recognize emerging patterns (Hoey, 2014). Sometimes, an event might look unimportant at the moment but further analyses of fieldnotes might reveal a sort of ritual between people. Ethnographies develop through fieldnotes, in the constant discovery of understandings and interpretations that then might lead to relevant findings (2014).

My fieldnotes were organized in two sections: descriptive and reflective. The descriptive section was developed during fieldwork and consisted of documenting factual data, such as date, time, place, and people involved, as well as short phrases of paragraphs describing settings and events. This included behaviors, conversations, and situations. All of these descriptive observations were focused on the research questions in order to assess their relevance. Ideally, the reflective part (analysis of fieldnotes) was going to take place at the end of every day, or every other day. To be honest, this was not the case in practice. Doing fieldwork at home, a home that I have been far away from 17 
years, was in itself a sort of fieldwork and it did enrich my experience and knowledge about this study, but at times it was also a distraction. For this reason, the reflection section of the fieldnotes took place once a week or once every two weeks. This section included thoughts, reflections on meanings, clarifications and particularly follow-up questions. I documented all of this analysis and reflections on a Word document that included dates, places and times for both the descriptive and reflective sections. I used the data from fieldnotes to complement and triangulate the creation of child-root codes and secondary-root codes. Because I used a deductive approach, the three main themes related to my three research questions (effects of neo-extractivism, the role of the Bolivian state and indigenous women responses) were already established as child-root codes. The other principal and secondary themes however, were not. Therefore, root codes emerged principally from interview data, and my first list of child and secondaryroot codes was extensive. Especially for secondary-root codes, I was uncertain which codes should be secondary and which ones should be left aside. Fieldnotes helped me to recognize which themes were dominant in order to transform them into child and secondary-root codes. Fieldnotes therefore, helped with the validation of coding. Fieldnotes also helped me to contextualized the data from interviews and focus groups." Simultaneously, I classified and labeled fieldnotes into child-root and/or secondary-root codes, and then I included them as part of a visual matrix (visual hand-written map) as suggested by Gale et al. (2013). This charting or conceptual map included a summary of each root code and I organized it based on themes, locations (communities) and actors (community, key actors, government, etc.), and this allowed me to identify 
commonalities and contradictions between these categories.

\subsubsection{Focus groups}

Data analysis for focus groups was drawn from transcripts and also from the notes I took during the focus groups. Having transcripts helped me analyze the research questions and my own notes in great depth to "better [understand] the phenomenon of interest" (Onwuegbuzie et al., 2009, p. 4). Focus group notes were based on documenting participants' perceptions, assumptions, and recommendations. The unit of analysis for focus groups was the group (since the focus group participants were members of two collectives) and emergent themes received special attention. Many times, however, I also analyzed their individual perspectives to capture the unique positionality of focus group participants. Analysis also included information about interaction between participants, level of consensus, dissent (also known as argumentative interactions) as well as information about nonverbal communication to increase the richness of data (Onwuabvuzie et al., 2009). A reading of the research material was the first step to identify general thematic patterns (Green, 2006). The second step followed the same coding structure as for the semi-structured interviews, from pre-established macro categories to emergent categories and subcategories. I shared the notes on focus groups at the end of the meeting for participants to review them to make sure I captured their ideas. The principal categories of focus group analysis were included in the central framework under a column for focus group data.

In the section on (my) positionality, I mentioned that participants in this study, as well as other qualitative studies I conducted, did complain that very often outsiders, 
licenciados, come and ask all types of questions and then they disappear, leaving participants with no answers, no solutions and a feeling of disrespect. I also mentioned that there is an ongoing issue with researchers like myself who belong to the Western empire of knowledge extraction and production, which, similar to extractive capitalism, extracts raw "outputs" from the communities in the Global South to then transform them into academic "knowledge" from the North (Grosfoguel, 2016). In order to take a first small step to address these issues, I am planning to go back to Oruro, Bolivia in July this year (2019) and present the findings of this study to the participants and communities. The purpose of these presentations is to ask people who participated in this study about their opinions of this work and whether they are satisfied with my interpretations and representations of their lives. I am also planning to prepare a summary of this dissertation for the communities to keep, with the goal of helping them document the effects of mining contamination in their lives. 


\section{PART II}

\section{CHAPTER FOUR. NEO-EXTRACTIVISM EFFECTS ON}

THE LIVES OF INDIGENOUS CAMPESINX WOMEN CHAPTER FIVE. THE STATE AND NEO-EXTRACTIVISM, A LOVE AFFAIR CHAPTER SIX. RESISTENCIA 


\section{Introduction}

In Part II, I describe the patterns I found during fieldwork in Oruro, Bolivia between October 2017 and June 2018. I offer a description of what participants shared during interviews about their daily experiences and perspectives around extractive capitalism and the Bolivian state. My goal in this chapter is to present the narratives, perspectives and experiences of participants with minimal analysis and explanation; I let the voices of participants speak and present their opinions as they were expressed. The presentation of these findings focuses primarily on themes and patterns found in the interviews with a variety of key actors involved in the complex relationships between mining, the state, and indigenous campesinx communities. Primarily, these interviews are with indigenous campesinx women leaders; however, they also include interviews with key community actors, members from CORIDUP and CEPA, and government officials. The findings also include the discussions from the two focus groups carried out with and Las Ramonas collectives. Participant observations of community life as well as observations during CORIDUP and community meetings also informed my presentation of these themes and patterns. I want to highlight that particularly for the findings on the state and neo-extractivism, the reflections of participants do not always pinpoint to specific gendered effects. Rather, as Ahlers and Zwarteveen (2009) argue, gender as well as class and ethnic relations, and their interdependency, mediate how mining contamination affects women in the Andes (2009). In other words, participants' reflections often reveal community effects, rather than gendered ones. I will provide an analysis of this dynamic in Part III. 
I present participants' testimonies in three chapters, organized around the three research questions of this study. Chapter Four presents participants' perspectives and experiences about the effects of neo-extractivism in their lives and their communities. The focus of this section is the deterioration of subsistence agriculture and the ongoing rural-urban diaspora that indigenous campesinx communities in the Andes have experienced as a result of mining contamination. A boom in the international demand for quinoa since 2013 has promoted community revitalization. However, this revitalization is not possible in areas heavily contaminated by mining, such as the communities in this study. Finally and most notably, participants revealed that lack of access to clean water is at the epicenter of all these issues and conflicts. Indigenous campesinx women's stories exposed the centrality of water in all aspects of their daily lives, both as subsistence campesinxs and as women taking care of their families and communities.

Chapter Five focuses on the role of the Bolivian state in shaping relations between extractive capitalism and indigenous campesinx women and their communities. The main findings in this section revolve around the Bolivian state's ambiguities; where on one hand it uses an anti-capitalist and anti-colonial discourse, while on the other hand, the state favors the extractivist sector using multiple strategies. Participants revealed four distinct strategies that the Bolivian state uses to conceal such paradoxes. First, the state has created a contradictory legal framework that supports the rights of indigenous communities and the environment, while at the same time it surpasses the right of the state as a decision maker over natural resources and also surpasses the rights of the mining sector. Second, to avoid criticism and dissent, the state creates an inclusive 
atmosphere based on ethnic inclusion that paradoxically perpetrates class discriminations against indigenous campesinx communities. Third, the state uses a divide and conquer strategy, accentuating existing divisions while creating new ones, such as divisions based on party affiliation. Fourth, the state increases the bureaucratization of everyday life and social movements, which weakens dissent and attempts at grassroots organizing.

Chapter Six presents the strategies that indigenous campesinx women use to organize and challenge the impact of state-led extractive capitalism on their lives and their communities. A custom of rotational leadership among indigenous communities in the Andes shows how this leadership mechanism has opened important, although unequal, spaces for indigenous campesinx women to organize and become leaders within their communities. In return, indigenous campesinx women leaders own their leadership positions and use them to challenge authority and power. At the community level, organizing efforts are exemplified by CORIDUP and its demand that mineral extraction be carried out in a more responsible manner.

Indigenous campesinx women also embrace practices of cooperation and solidarity throughout their daily activities, which are part of individual and community organizing efforts against neo-extractivism. Chapter Six also presents participants' perspectives and their articulation of what it means to be indigenous. Last, this chapter includes the urban-rural coalitions that different groups created based on fluid notions of indigeneity and gender in order to challenge extractive capitalism. 


\section{CHAPTER FOUR}

\section{NEO-EXTRACTIVISM EFFECTS ON THE LIVES OF INDIGENOUS CAMPESINX WOMEN}

I did not hesitate when Don Miguel, 67, suggested that I do fieldwork in his community Kochi Piacala in Machacamarca, which is located 30 minutes by car and two hours walking distance from the Machacamarca town (there is no public transportation here). He is a well-respected local leader, and when I presented my research at the monthly community meeting, people were very receptive and welcoming. They were also very skeptical and laughed when Don Miguel told them that I wanted to stay in Kochi Piacala for at least two weeks to see the daily life of comunarixs. Don Lucho, another community leader, stated, "you are not going to last even one day in there, licenciada.",50 I asked why, and people continue laughing without explaining. I did not push for an answer. Doña Paula, a 70-year-old comunarix, offered me a place to stay. She mentioned being very poor, that her house was made of thatch and clay, but that she could make space in one of her two rooms for me to sleep on top of a sheepskin, which is what indigenous campesinx communities in this region use as beds. I thanked her and accepted her offer, and I promised I would bring some goods such as bread, sugar and coca leaves.

This monthly meeting had at least $25-30$ comunarixs and its libro de actas [minute book] listed around 120 families belonging to Kochi Piacala. This created an anticipation of what communal life would look like. In the central plaza I would observe older people talking, children playing, and some street vendors offering food, and I

\footnotetext{
${ }^{50}$ People from indigenous campesinx communities might refer to outsiders as licenciada (o) in reference to the assumed technical or licensed degree outsiders have. It might show respect, but it often signals distance and the position of the licenciada (o) as an outsider to the community.
} 
thought that I could help the women with their children, washing dishes or clothes while observing their daily activities and conversations. This image changed the first day I arrived in the community. Due to the ongoing contamination of water sources, Kochi Piacala has experienced an intense migration of its inhabitants to the towns of Machacamarca, Poopó, and the city of Oruro, as well as to Argentina and Brazil. Currently there are only four families living permanently here. Their houses are far away from each other, at least a half mile or more, and there is no central plaza or a sense of a center, or even a sense of community. "There is nothing to observe here!" was my first reaction to this unexpected reality. Figure 8 shows one of the four mud houses in Kochi Piacala. There is no plaza, no children, no women washing clothes, no social life. And it was precisely this, this lack of social life, this nothingness to witness that became everything to witness about the subtle yet vicious ways that extractive capitalism affects indigenous campesinx communities, especially women.

In this chapter I present participants' experiences and perspectives about the effects of mining contamination in their lives. They all explained that although there are many factors that affect their communities, mining contamination is the central factor provoking the ongoing rural diasporas these communities have experienced, leading also to the unfeasibility of a return and revitalization of these locations. Participants also highlighted the centrality of water in all aspects of their lives and how lack of access to it due to mining contamination makes all their survival activities (growing crops, raising livestock) extremely difficult, if not impossible. 


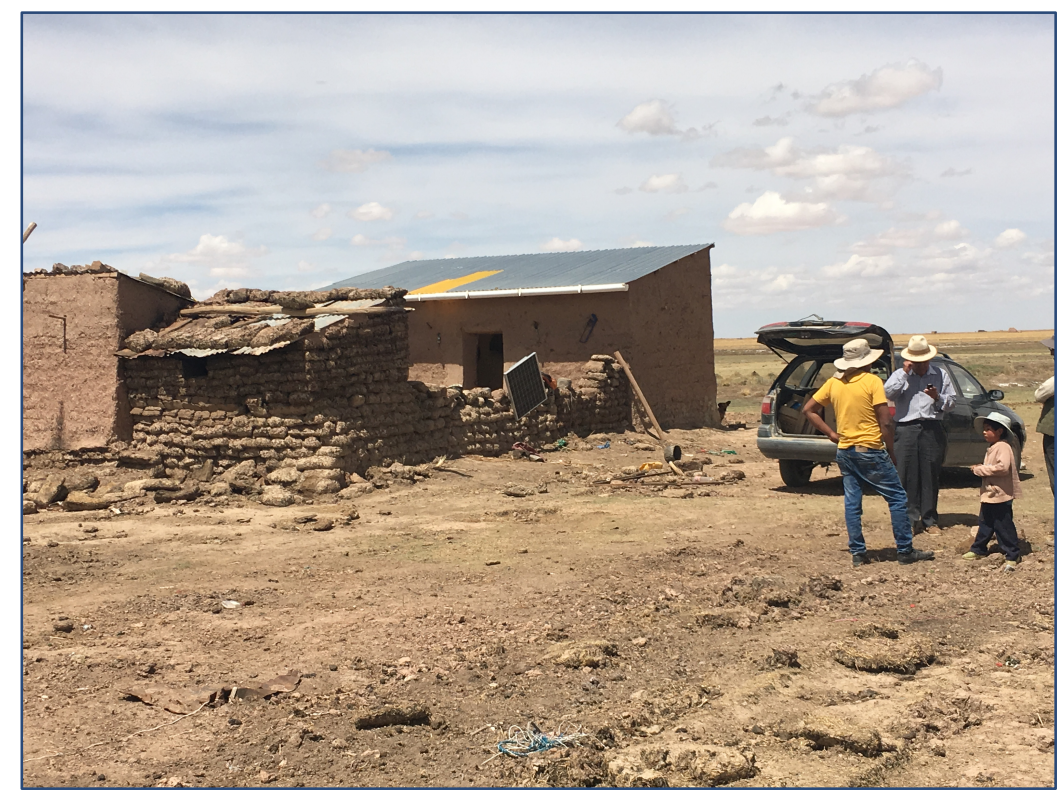

Figure 8. Kochi Piacala community. Photograph by the author

\subsection{Rural diasporas back and forth}

“Residentes, ” Doña Paula replied to my startling question about the 120 families missing from her community. She explained that unlike comunarixs, people who live permanently in the communities, residentes [residents] are people who have land in the community, but they live somewhere else. Residentes might spend one to two days, usually weekends, in the community, although this fluctuates significantly by person and community. Residentes also include people who do not have any land but keep community connections by participating in meetings, taking leadership roles and paying the yearly-required community contribution, between bs. 20-bs.50 (\$US 3-5) that is used for different causes, from political organizing to local fairs. At first this reality was difficult to understand. Luckily, one of my first interviews was with Doña Jacinta, 57, from Alantañita, Machacamarca who explained this in detail: 
Other people do not have a place or land any more; the contamination is dispossessing them, the soil is worthless, there is no grass, everything smells of copagira [acidic liquid runoff from the mines], everything is full of lama, not even thatch grows in here, so how are they going to survive? They have no option but to leave. But others also come back and forth; they have a house there but also land in here.

This pattern of living in cities and towns and having rural lands somewhere else is known as double residency and is a very common trend among rural communities of Oruro. Doña Raquel, 65, works for CEPA's socio-environmental justice unit as the person in charge of providing support to the communities affected by the drought around Lake Poopó. She explained, "the double residency is also called permanent exit, but for example in the Choro [municipality], although people have moved to the city of Oruro, they come and go, so it is not permanent... they still keep a link with their communities. How? Through the leadership roles they have to fulfill." In parallel to the communities in Machacamarca, this pattern of double residency also affects the communities in Poopó. Doña Victoria, 49, was a Mama T'alla for Quellia, Poopó in 2016 who lives in the city of La Paz, but often travels back to Poopó, meaning she is a residente. She described this dynamic: "There are 114 people within the Quellia Ayllu that are divided in three communities, but the majority are residentes, they live in the Poopó town so they come and go to the community, but the ones that really live in the community, that stay and do not leave are six families."

Although a common pattern across many rural communities in Oruro, this reality 
is usually ignored or overlooked because it does not fit nicely into the rural-urban dichotomy or the romanticized relationship indigenous campesinx communities are supposed to have with the land. As Doña Silvia, 51, from Puñaka, Poopó, mentioned, "people [from Huari and Llapallapani towns] have migrated to other places looking for work... I mean that this [migration] has not only happened around Lake Poopó, this is something that happened around all the mining centers."

\subsubsection{Natural and not so natural reasons for the rural diasporas}

There are multiple factors that have affected this rural migration, here described as double residency. The decomposition of subsistence agrarian economies in el Altiplano started in the 1970s, reaching its greatest disintegration between 1982-1984 (Webber, 2017). Irregular climate changes such as El Niño provoked major droughts in el Altiplano (Webber, 2017; Gruberg \& Andreucci, 2015). Equally impactful, however, were the socio-political decisions of that time. The debt crisis of the 1980s, accompanied by the structural adjustment conditions imposed by international financial institutions, caused an increasing emphasis on agricultural trade liberalization and free trade agreements with regional trade blocs such as MERCOSUR (Southern Common Market), which provided no protection for domestic peasant production. This had a particularly adverse effect on the production of traditional crops such as potatoes, onions, and barley that left indigenous campesinxs unable to compete (Webber, 2017). Since the 1950s, there has also been an ongoing pattern of state partiality toward agribusiness capitalists via subsidies, and a bias against campesinx economies or those agricultural productive 
units led by families and communities "that are precariously connected to the agricultural and labor market" (Colque, Urioste \& Eyzaguirre, 2015 p. 6).

While recognizing these macro effects on subsistence agrarian economies across el Altiplano, participants in this study decisively concluded that mining contamination of waters and soils and the subsequent destruction of all aspects of indigenous campesinx lives is the central factor forcing people to migrate. Doña Elena, 68 , a former Jilakata (another name for the maximum indigenous authority) for the Sorachico Ayllu argued that, "la contamination es siempre el mayor motivo para irnos" [contamination is the main reason for us to leave]." It is important to emphasize that this perspective of mining contamination as a major driver of the rural-urban migration and the double residency was shared across the different participants in this study, from comunarixs to government officials to CEPA representatives. Don Luis, 43, CEPA's general coordinator, for example, concluded, "basically contamination is resettling them, it is taking communities out and this is worrisome because if people leave, who takes care [of the community]? Who complains?" Similarly, Don Alex, 52, the water systems supervisor for the Huanuni municipality, reflected that "contamination goes straight to the waters and the soil, there is no grass for animals so people have to migrate... there is no production of basic foods, there is nothing to do, so then people leave." Doña Victoria, 49, a Mama T'alla and residente of Quellia, Poopó echoed this feeling. She lives in La Paz and usually travels back and forth between La Paz, the Poopó town, and Quellia because she is a small trader. When asked why people leave, she replied: "People leave because there is no production. This year [2018] this place [Quellia] has produced nothing, so how are 
people going to survive? There is no food for people or animals; this is why people leave."

As described above, participants emphasized how contamination affected production of subsistence crops. Below, Doña Jacinta, 57, makes a particular emphasis on the effects of mining contamination on the raising of animals. Doña Jacinta is a comunarix, among the few people from Alantañita, Machacamarca who still lives permanently in the community and relies on livestock for her subsistence:

Before contamination how did we survive? Only from our sheep and cows, with their milk and cheese, their meat and also their wool, we would have 500 sheep and more than 50 cows, now we only have $50-60$ sheep...we can no longer survive. Before everything would be produced here, even the clothes would be from the sheep, now not anymore.

Many participants shared nostalgic memories of life before the mining contamination. Doña Patricia, 43, from Puñaka, Poopó, for example, expressed, "that water, copagira (acidic liquid runoff from the mines) comes down, and it burns everything. Before it was really nice, we would grow potatoes, quinoa, a lot of quinoa; now we cannot, some grow, but not like before. The soil does not produce anything." Similarly, Doña Pamela, 70, a comunarix from Alantañita, Machacamarca, reflected on her memories of this past: "Before, our community was really nice, my dad used to grow potatoes, quinoa, haba, he would grow everything and we grew up with everything natural...now our community is disappearing little by little, the soil is contaminated...our community is sad."

\footnotetext{
${ }^{51}$ In comparison to the other three communities, Alantañita has more comunarixs (people who live there permanently). The reason might be that although Alantañita is heavily contaminated, it is closer to the urban town of Machacamarca, around 30-45 minutes walking, making it easier to go back and forth.
} 
The lived experience of having to leave one's community because of mining contamination is perhaps best captured by Doña Carmen. She lives in the town of Machacamarca and goes everyday to the city of Oruro to sell hairpins (\$US 0.75 each) on the streets. On average, Doña Carmen told me that she makes bs. 50-100 (\$US 8-15) per day. Like Doña Carmen, the majority of indigenous peasant women who migrate to the cities become part of the informal economy as street vendors, predominantly selling food and other items (Galindo, 2014). Figure 9 for example shows women selling food on the streets, a very common activity particularly for indigenous women. In these pitures, two indigenous immigrant women sell ch'arki de llama (jerky llama meat) and aji de cordero (lamb dish).

Doña Carmen left Kochi Piacala 25 years ago because she had twelve children and could no longer survive as a campesinx. She does not have any land in the community but participates in its meetings and events; therefore she is considered a residente. She described how contamination generates these rural diasporas: Mining has taken everything away from us, it has affected our lands, and if it were not for mining right now we would be well off, standing up like before. We used to have cows, sheep, and we could have continued that way, but when mining came to our communities, it burned the soils. As I told you before, we used to have seven types of grasses, now nothing...Clearly it is contamination, because of contamination we migrated, not for other reasons; if there was no contamination, we would have stayed in these lands, but contamination kicked us out; it is as if someone else occupies our house now, 
and we are out, that's how contamination has kicked us out.

In 1985, when orthodox neoliberalism was imposed in Bolivia, thousands of women where expelled from their houses, their communities and their countries to survive on the streets, becoming the social support and the safety net to replace the support that the welfare state provided (Galindo, 2014). Mujeres Creando [Women Creating], the well-known anarcho-feminist collective from La Paz, Bolivia, calls these women las exiliadas del neoliberalismo [the exiles of neoliberalism] (2014). Women migrants are also less likely than men to participate in the formal sector and waged labor, and therefore they are trapped in the informal sector (2014).

The dynamics also affect family structure as it is often young generations and/or adult men the ones that leave their communities while women stay taking care of the land. In parallel, whole families migrate; yet it is the women usually continue a relationship with their communities by being residentes. Some participants also mentioned the class differences that immigration creates. Residentes might still be poor or working class in the cities, however, they usually acquire more and better economic means than comunarixs, the people who stay in the communities. Such class differences are evident in the tensions that emerge sometimes between community leaders (many of them residentes) and the communities. 

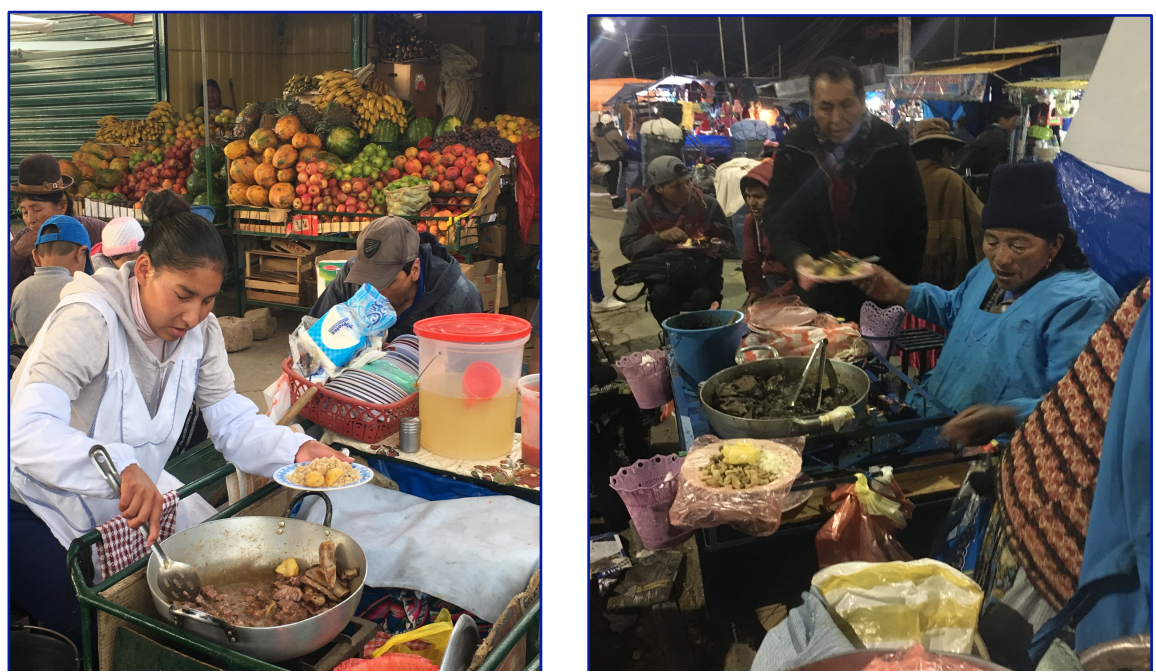

Figure 9. Women selling food on the streets of Oruro city. Photograph by the author.

While these previous perspectives place an emphasis on the impact that contamination has had on indigenous peasant production, participants also described other effects, particularly community changes through time. According to Doña Jacinta, 57, from Alantañita, Machacamarca, "those times the countryside was very nice, those times it was very beautiful. We used to have everything. We had our wild ducks, their eggs and the fish... back then I was very happy, we had fresh water... now it is grievous, the countryside is a sad place, no one wants to stay anymore." Like other participants reflecting about their lives from past to present, Doña Jacinta highlighted the changes within her community in relation to the rivers and wildlife, both animal and flora. Similarly, Doña Jazmin, 50, from Kochi Piacala, Machacamarca reflected on how much wild fish the rivers around her community used to have:

We would fish right here, we had a net, and with that we would catch the fish, splash splash! The fish would jump, we were very happy that we would jump 
too, we would dance because of the fish, there was one, two, three fish, then we would get one arroba (one quarter of a quintal) and we would eat fish soup, also jerky fish. Now we have nothing of this, nothing, everything is dried up... our children, the majority are leaving to Argentina, Brazil, and Spain because there is no life here, you can see it, it's palpable, it is difficult. The description from Doña Jazmin about the fish makes sense since the name of her community, Kochi Piacala, comes from the Quechua word kocha, meaning lagoon. ${ }^{52}$ Don Miguel, 67, also described the water-like atmosphere of his community: "Kochi Piacala was a river, it was a really nice place. There were lagoons, and a lot of Totora [local sedge]." However, this seems unimaginable nowadays. When I stayed in Kochi Piacala in 2017, there were no rivers or lagoons in its vicinity and the grass was so dry that it produced a crunchy sound similar to potato chips. My visit was right before the rainy season, so this might explain the dryness and desert-like landscape. However, participants explained that even when it rains, the river fills only temporarily and there are no more fish to catch.

For the communities of Quellia and Puñaka that are located in the Poopó municipality and closer to Lake Poopó, water contamination brings another layer of ramifications. Don Aurelio, 48, who was the Mayor of the Puñaka Ayllu in Poopó in 2017, gave an account about the changes his community experienced, particularly related to fishing activities:

\footnotetext{
${ }^{52}$ When I asked, participants gave me different explanations about the meaning of Kochi Piacala, from river, to lagoon to something similar to wetness. Nevertheless, the name describes the presence of water in or around the community. Mario from the Wasi Pacha collective and whose family is from Kochi Piacala told me he once found a document where it stated that Kochi comes from kocha, which means lagoon.
} 
Contamination was evident in this municipality so then fishing started to decline, which reached its lowest point of maybe zero production in the ‘90s... and you know, many people in my Ayllu were fishermen... so the high migration in my Ayllu [Puñaka] started in that decade and since then our Ayllu has been empty.

Whereas in the municipality of Machacamarca people would fish as a complementary activity to subsistence agriculture, in Poopó, fishing used to be a dominant activity for many people. Most of them would fish around Lake Poopó, Bolivia's second largest lake that dried up in 2016. Many of the fishermen near Lake Poopó are the Urus, who describe themselves as traditional fishermen and La gente del Lago [the people from the lake]. The Urus have distinct clothes and traditions than the Aymaras and Quechuas. The Urus men in Figure 10, for example, wear their traditional white and beige ponchos, and their hats made of thatch. In this figure, two Urus men are showing their boat in the dried up part of Lake Poopó. ${ }^{53}$ Unlike the Quechuas and Aymaras who are an indigenous majority, comprising about 40-60 percent of the total Bolivian population, the Urus are an indigenous minority that live in the proximities of Lake Poopó. Nevertheless, the Urus inhabited this region before the Inca conquest and the name of the department Oruro, comes from the Urus (Condarco, 2015).

\footnotetext{
53 The drying up of Lake Poopó, along the high migration around the 90s that Don Aurelio described above has had a significant and direct effect on the Urus del lago. The drying up of Lake Poopó has also highlighted the historical ethnic tensions between the Urus and other indigenous peoples who live in the same communities. This is the case of the Puñaka Ayllu, for example. Often times the Urus del lago are not granted access to TOCs (Communal Indigenous Lands) under the pretext that they are by tradition, fishermen, therefore they have no rights to land. When I was in the town of Poopó in 2018, while having a conversation about the Urus del lago with a person who self-identified as indigenous, he told me that in his community also live the Urus del lago, but "ellos no son de aqui, ellos son solo del lago, son inquilinos nomas" [they are not from here, they are from the lake, they are only tenants here].
} 
The 2012 census states that there were about 120 families who are Urus del lago (Urus are divided in three sub groups, the total being around 800 families). In 2016 Lake Poopó dried up completely. There were many reasons for this, including climate change, government negligence, and mining contamination (Gruberg \& Andreucci, 2015). The Urus del lago were heavily affected by this, causing many to leave their traditional ways of life to seek work in the nearby towns. Nevertheless, many Urus del Lago, while being traditional fishermen also engaged in other economic activities before Lake Poopó dried up. Many would work part time in the towns as construction workers.

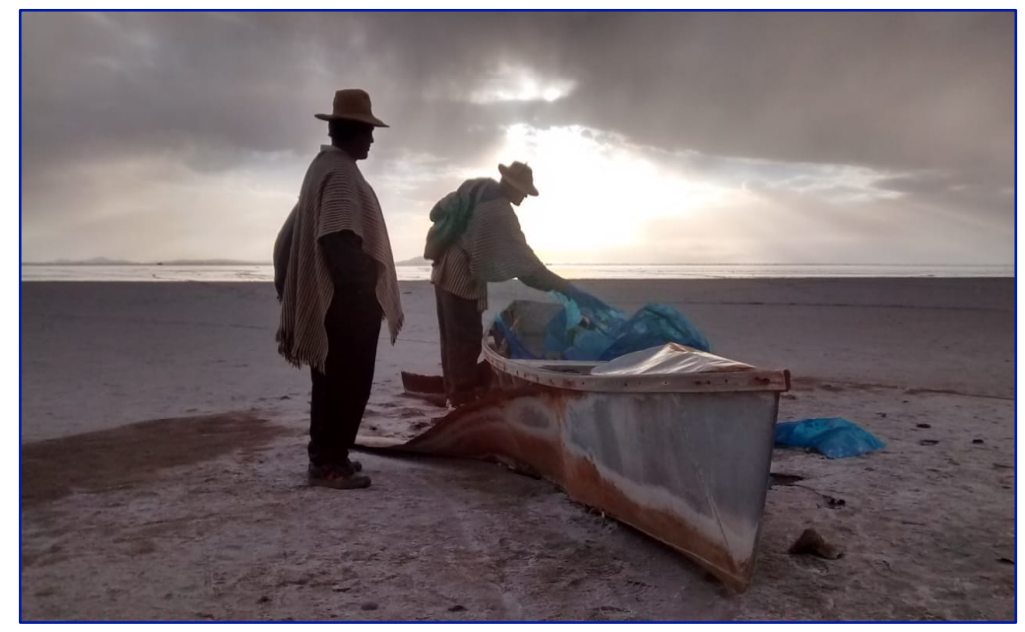

Figure 10. Los Urus del Lago, Indigenous Peoples of Lake Poopó. Photograph by the author. In this picture, two Urus men are showing their boat in the dried up part of Lake Poopó.

\subsubsection{But when and how long ago?}

Participants shared their experiences and perspectives in great depth and in a way that one could sense and even feel their feelings of frustration for the loss of their ways of life. Yet, what remained unclear to me is how far back in the past these changes within their communities had occurred. After all, during colonization, Oruro was the second largest producer of silver after Potosi, and the Huanuni mine was founded in 1883 as 
the tin market started booming (Quillaguaman, 2016). Contamination has been an ongoing issue for decades if not centuries. So how far back were participants' memories reaching?

Don Aurelio, 48, from Puñaka, Poopó, explained, "in the '90s, mining started high production... and then migration also started." Similarly, Don Miguel, 67, from Kochi Piacala said that "there were always mining activities but the water was not contaminated. We used to drink it. Since 1985 I came back here [Kochi Piacala] to grow quinoa, potatoes and to take care of the animals. However, ever since, contamination has been expanding to our community." In relation to Lake Poopó, Doña Victoria, 48, shared the following: "Little by little the lake has been drying up, there was no work, therefore people started migrating around '95-'96, the majority left to Argentina, complete families left because the fish they used to take to sell to La Paz has been disappearing."

According to Colectivo CASA, a non-profit organization that works on environmental justice in Oruro, water and soil contamination from the Huanuni mine started around the end of the 19th century. Nevertheless, communities downstream of the Huanuni sub-basin's rivers only started to feel its impact around the 1990s (colectivo CASA, n.d). According to Colectivo CASA's reports, Kochi Piacala was the first community in this region to denounce the effects of mining contamination on its soils. There were also technological changes around the 1980s-1990s, when more advanced machinery allowed for an increase in mineral production, which correlates with participants' perceptions of higher contamination since the $80 \mathrm{~s}$. 


\subsubsection{An exodus with no return}

El Altiplano region of Bolivia and Peru is the traditional and leading quinoa producer of the world. Between 2005 and 2013 quinoa production experienced a boom in demand from the Global North nations, leading to an increase of 600 percent in its price during this time (McDonell, 2018). What used to be considered derogatorily in Bolivia as comida de Indio [Indian food] became a fashionable hipster food. While some argued that such hikes in price reduced the local consumption of quinoa among indigenous peasant communities, evidence shows otherwise. Quinoa continues to be consumed among rural communities, and its consumption has also increased among urban dwellers in Peru and Bolivia due to quinoa's de-stigmatization. However, a less well-known effect of the quinoa boom is that it created the circumstances and motivation for many indigenous campesinxs to return to their communities, leading to a repopulation and revitalization of indigenous peasant life (Tschopp, 2018).

The participants in this study were also traditionally quinoa producers, and their accounts attest to this. Doña Carmen, 76, from Kochi Piacala, Machacamarca remembered, "quinoa used to grow every year, like a lot! My dad would also produce pito [quinoa powder], and a lot of people would come to produce quinoa." Similarly, Doña Patricia, 43, from Puñaka, Poopó recalled that "here [in Puñaka] we used to grow quinoa, especially in our sector, down the river. Because it is close to the river, we would bring quinoa in trucks." They also shared their attempt to revitalize subsistence agriculture around quinoa due to its recent boom as well as other products, all in vain. Regarding this futile attempt, Doña Mariana, 58, from Alantañita, Machacamarca shared 
the following:

I used to grow quinoa and potatoes on a little parcel that belonged to my mom... Recently I have tried to even grow crops using a tractor, but nothing came out, just a few (crops) have grown and they do not grow completely, the potatoes for example have growth like little cachinitas [tiny rocks] and all contaminated. We paid for the tractor but it was in vain, it was useless. Now I have to pay back that money.

While other communities benefited from the quinoa boom and the repopulation and revitalization of communities, the participants in this study did not. What Doña Mariana described above about Machacamarca reflects the experiences that other participants shared. Don Aurelio, 48, from Puñaka Poopó, also shared his experience and perspective about this:

When we saw that the soil situation was very bad, we asked, why should we go back? Why should we go back if the soil is about to die? There is nothing, there is no incentive to go back like other communities have. We only go back for traditions; we visit the community for a short time. But would I tell my children 'let's come back and grow crops?' No, there is no potential; we do not have that anymore.

In a context of mining contamination, such efforts to revitalize subsistence agriculture and indigenous ways of life are just not possible. In other words, mining contamination creates a very hostile socio-environmental landscape that makes any revitalization and return efforts almost impossible. 


\subsubsection{Lucia and Papucho: on the relationships with animals}

It was during a CORIDUP meeting that a former Mama T'alla from Collapampa decried the effects of mining contamination on her life, and the lives of her animals:

Tata Mallkus, Mama T'allas, hermanos, hermanas, quiero que entremos en la reflexion, donde esta la conciencia? una pena es nuestra comunidad, nuestros animalitos también una pena, cuando nuestros animalitos toman agua, se enferman, les da diarrea, como comunaria me duele, que vamos a hacer? [Tata Mallkus, Mama T'allas, brothers, sisters, I want us to reflect on these [mining] issues, where is consciousness? Our community is saddening, and so are our animals; when our animals drink water, they get sick, they get diarrhea, and it hurts me, what are we going to do?

The way she expressed these words about her animals impacted me; it was as if she was talking about her friends, or family. Before fieldwork, I had not even considered understanding the effects that mining contamination had on the relationship between indigenous campesinx communities and animals. I was expecting to find this type of relationship between participants and their lands, the famous Pachamama. Participants did express a deep sense of connection to the land (which I will explain in more detail on the discussion about indigeneity) but the sentiment towards animals was startling.

My anthropology background taught me how problematic it is to romanticize people and their relationships with nature, and I thought that maybe I was romanticizing this statement. However, during my interviews, it became evident that these sentiments towards animals were genuinely expressing a deep sense of caring and closeness. Doña 
Paula, 69, for example told me, "mis waquitas mal siempre estan, pero igual siempre trato de darles agua limpia [my little cows are sick, but I still try to take them to drink clean water. The use of diminutives "ita" "ito" in words such as "mi vaquita, mi ovejita, la chanchito" [little cow, little sheep, little pig] that Doña Paula and other participants used to talk about their animals, rather than describing size, describes affection towards that to which it is applied. Their animals also had names and participants attributed to them human-like personalities. During my stay in Kochi Piacala, often times Doña Paula would say phrases like these: "You see, el Oscar [the bull] is spoiled and slick! He wants to run away, he is sneaky," or "these sheep give me headaches, they are shameless and slick.” Doña Elena, 68, a former Jilakata from the Sorachico Ayllu and a CORIDUP leader, also shared a similar sentiment towards her animals:

When I used to travel, I would always think how my sheep were doing, I wanted to come back just to feed them grass. I used to take them to drink water very early in the morning ...but one day one of my sheep, the biggest one, the one with a lot of wood, el Papucho [the handsome] stayed behind...The next day I came back and I found el Papucho drinking from the [contaminated] river. And I said 'Papucho no! Where did you go last night? Where did you go party?' He was hung over, and I was joking. Then I took him back that morning, but the next day, Papucho died and I cried a lot.

It is true that these farm animals are used for subsistence, and therefore it seems logical to care for them so people can get better products (meat, milk and cheese). Since participants have fewer animals, it might also be that each animal becomes more 
important. Nevertheless, Doña Elena challenged these assumptions:

Gisela: You used to travel back and forth just to bring Lucia fresh food?

Doña Elena: Yes, because my cow was beautiful...I would come to my lands to feed her with grass, I would bring her lettuce from Oruro, I would bring her alfalfa, I would buy barley for her, but she died anyway, she was very skinny. I thought, why is Lucia so skinny? Her calf also died, who knows, maybe they drank the [contaminated] water, and maybe that's why they died".

Gisela: Ahh, I am sorry she died, but did you also love her because she produced milk and other goods for you? Or why were you so nice with Lucia?

Doña Elena: That is true, yes, but also because I cared for her, animals also suffer and they need to be healthy, so I used to take my animals further away so they could drink good water, good grass and stay healthy.

\section{2. "Sin agua no hay vida" [There is no life without water]}

Doña Teresa, 38, from Alantañita, Machacamarca explained that "sin agua no hay vida ...it is really hard to take care of my children, to cook, to wash dishes and my cows suffer a lot to, and it is a lot of work to get clean water." Doña Teresa is a comunarix, meaning she lives in her community permanently where she relies on her livestock (cows and sheep) to survive as well as selling food on the Machacamarca town during the weekends. She has five children, two of whom live with her in the community; they sometimes stay with family members in the town of Machacamarca. Like other participants, Doña Teresa's narrative about water focused on the detrimental conditions that mining contamination, specifically contaminated waters, have created for 
women. This is noteworthy because some studies in the literature review argue that women affected by extractive capitalism often use essentialist narratives of connections between women and Pachamama to describe and legitimize their struggles (e.g., Jenkins, 2015). The indigenous campesinx women and key actors whom I interviewed, however, did not mention such essentialist narratives. Capturing the way that water contamination affects women's lives and activities, Doña Victoria, 49, from Quellia, Poopó explained: It is obvious that we women have the worst part in this contamination because we are the ones who have to find new ways to obtain water to give to our children. Men instead, they work and come and go, they take water in a cup from a pipe or somewhere else, and they forget about it. Women, we have to be aware of this, that this [contamination] disfavors women; it put us in trouble because we have to face the reality we are living in. I was talking with my husband and we concluded that women always take the worst part. We carry water in buckets, and we tell our kids not to wash their faces, we are always on alert, because contamination is visible, anyone who arrives in our community can see it.

Her and others' narratives are based on the socio-material conditions that contamination provokes, in both subsistence production and social reproduction. Moreover, although there are many reasons why people have to leave their communities such as soil contamination, lack of crops, sick and dying animals (and therefore no more production), and an inability to raise children, all of these reasons are interconnected through water, making water the epicenter of all their struggles. The following paragraphs incorporate 
participants' accounts on this matter.

The four communities in this study lack access to clean water. The Huanuni mine does not have a tailing dam, therefore copagira [acidic runoff] goes straight to the San Juan de Sora Sora, Santa Fe and Huanuni rivers leading eventually to Lake Poopó. These communities are located near these rivers, and in the case of Kochi Piacala and Alantañita, right downstream of the Huanuni mine. There is therefore, an ongoing accumulation of mining waste and mining sediments in their lands (Perreault, 2013). This situation generates environmental liabilities through acidic rock water, very toxic waters that spread to the rivers (CEPA, 2009). The result has been an ongoing contamination of surface and underground water around the Poopó basin and the Huanuni sub-basin. There are, however, few studies that analyze the extent of mining contamination in this area. A 2005 study from UTO (Technical University of Oruro) found that the contamination that goes into the Huanuni river includes 15.6 tons of heavy metals per day, including arsenic, cadmium, and lead, with levels above the acceptable limits according to environmental safety norms, making these metals poisonous for human and animal health (colectivo CASA, n.d).

Participants have tried different ways to obtain clean water, sometimes individually and sometimes communally with the help of different organizations. Rainwater and cosecha de agua, or water harvesting techniques, might sound like a logical solution. Since 2016, Catapa, a volunteer-based Belgian nonprofit organization that works on sustainable development and alternative globalization, has provided these communities with collective systems (via roofs) and water tanks to harvest rainwater, 
with mixed results (Catapa, n.d). For one thing, water-harvesting techniques work only during the rainy season. "It has not rained since May and we usually have rain by the day of the Dead [November second] but now the rain has been late" Doña Paula told me during my stay with her, which was the first week of December 2017. In other words, I was there for the rainy season that was supposed to start around November, yet it was December and there was no rain. As Doña Silvia, 51, from Puñaka, Poopó described, "it seems that the weather is sick and tired," referring to the extreme and unpredictable seasonal changes in recent years, where there is no rain in the dry season and the rainy season comes later than usual and with extreme floods. Participants also explained that although they might get water to cover their basic needs (washing hands, cooking) this does not cover their animals' needs, since la cosecha de agua is designed to cover only human needs (Lauren, Catapa, personal communication, February 3, 2018). Doña Jazmin, 50, who lives a mile away from Doña Paula told me that her water tank had a problem (the tank does not capture the water from the roof) and no one knew how to fix it, therefore she never used it. ${ }^{54}$ There are also issues with the distribution of these projects. Lauren, a Catapa volunteer explained, "we tried to give the [water] tanks to the people who really need them, the comunarios, but sometimes residentes that do not live in the place and do not need them have received the tanks just because they have more connections with CEPA and CORIDUP, and I disagree with that."

\footnotetext{
${ }^{54}$ I participated in an event where Don Miguel distributed solar panels to his community that were donated by another non-profit organization. A few weeks after this event, one of the families was not using the solar panel at all because no one knew how to install them. There was a strange switch that apparently was producing a short circuit. It is very common for organizations to donate or support communities with projects, and technologies such as this one; however, they do not provide the communities with any training on how to solve the technical issues that often times come with their donations.
} 


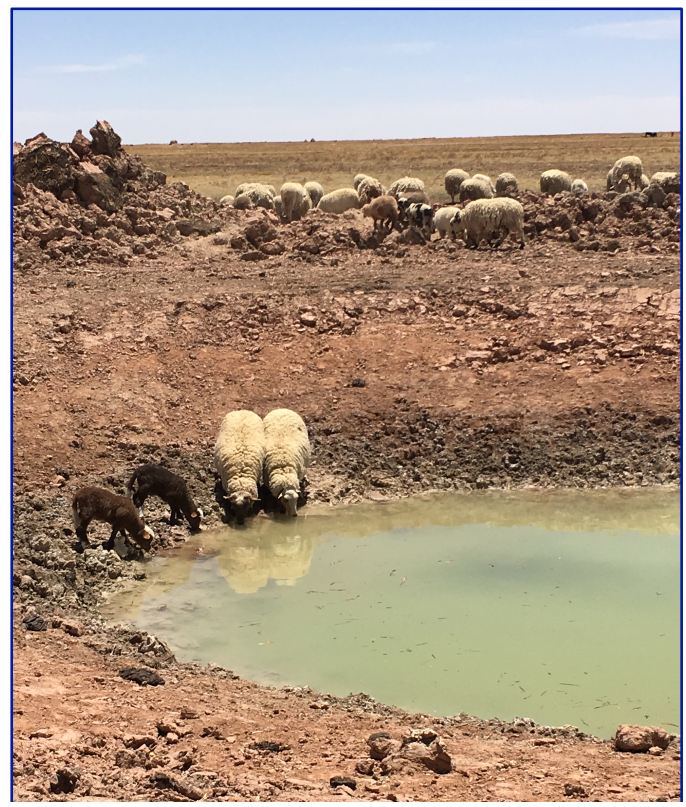

Figure 11. Wijiñas in the Kochi Piacala community. Photograph by the author.

Wijiñas are ancestral man-made water deposits with a conical form. They look

like big holes on the ground and their purpose is to capture and take advantage of "semisuperficial currents and rain precipitation" (Flores, 2004). Depending on the community and the size of the wijiñas, they are built individually, or as a communal effort with funding from different organizations, including the government and non-profits. In my visits to the communities, I observed most wijiñas having greenish, slimy waters similar to Figure 11, and a funky smell that participants explained was the smell of copagira. "The soil is also so contaminated that the wijiñas, even directly from here [from this little wijiña] have bad waters. I have tried to collect it, but [the water] is salty, it tasted like urine and smells like copagira" explained Doña Jazmin, 50. It is obvious that no one consumes this water, not even the animals. One day I helped Doña Jazmin graze her animals; she took them to one wijiña near her house to see if the animals would drink it, 
but only a few sheep drank it hesitantly. It was a really hot and sunny day, and in el Altiplano, this means a very intense sun. Her shepherd dog Lupito was the only one that seemed not to care and jumped into the wijiña to take a quick bath. Don Alex, 52, the water systems supervisor for the Huanuni municipality explained, "yes, it is contamination, but how often do they clean them [wijiñas]? Do they place clay, chlorine and aquatic plants to keep them clean? No, they even throw their garbage into them." The issue, according to Don Alex, is lack of maintenance of the wijiñas. His conclusion is partially accurate. Some public and NGO-led projects for the communities include constructions of wijiñas. Yet, as participants explained, such projects lack explanations on how to maintain a wijiña clean or how a wijiña works. ${ }^{55}$

I asked about water wells, whether communities have them and if they use them. As Doña Tamara, 38, from Alantañita, Machacamarca described, "my water well is very close to my lands, so the water is nearby but it is undrinkable, you cannot drink anything from it." Participants explained that there were only a few water wells because they are expensive to build and most of the time these efforts are in vain as the underground water is also contaminated. Doña Mariana, 58, from Alantañita, Machacamarca illustrated this experience:

With JICA (Japanese International Agency) and with help of a tractor, the community dug in the hill right there, 70 meters of depth, I think. Every other day we would go to sleep over there to take care and help with the project... it was not a well, it was something with some pipes, but it was five of them. We thought it would be clean water, sweet water. We thought 'ah, the water is

\footnotetext{
${ }^{55}$ I observed something similar when an NGO donated solar panels to the Kochi Piacala community and participants had many issues as they did not know how to install them correctly.
} 
going to be so sweet, not sour or bitter as it is now', and that it would go to our fields and everywhere, but when JICA got the water, it was salty.

There are some contradictory accounts about the JICA project that might be related to memory recall. Doña Pamela, 70, for example, described the same project as follows:

The water from JICA was sweet, it was clean, so we thought that we could take it in a big tank and through pipes we would distribute the water to each house in the community. However, the engineers took samples to analyze the water and when the results came back, it was contaminated. It was salty.

Participants from the other communities shared comparable issues with water wells and wijiñas that resulted in no access to clean and drinkable water.

\subsubsection{Visible and invisible consequences}

Water contamination has many consequences. The first and obvious is the health effects on people and animals. "Contamination goes straight to the water that is for human consumption, both surface and underground water gets contaminated with mercury and these causes illnesses ... so animals and people get sick from it," mentioned Don Alex, 52, the water systems supervisor from the Huanuni municipality. Don Miguel, 67, described how his mother and sister died from leukemia, which according to him is unheard of among communities from el Altiplano. He attributed this cancer to mining contamination and there are studies that show an association between digestive and hematologic cancers and proximity to mining industries (Fernandez-Navarro, GarciaPerez, Ramis, Boldo \& Lopez-Abente, 2012) . Doña Victoria, 49, from Quellia, Poopó described the gastrointestinal illnesses from drinking contaminated water: "These 
kids are growing up sick, even now they have gastritis and that's because of contaminated waters, and the crops are also not the same." Other participants like Doña Jazmin, 50, from Kochi Piacala, Machacamarca described the health effects of contaminated water on their animals: "Before we would make cheese, lots of it. Now we can't, the sheep don't produce even for their lambs. Before the animals would not die as they do now, they also get very sick and skinny." Participants also described the widespread issue with animals being born with deformities, something they attribute to mining contamination, "before our cows were fat, now they are small, they can't grow, and don't produce a lot of milk. As I told you, their calves are born with deformities, sometimes they have two heads, many times they are stillbirths," argued Doña Patricia, 43 from Puñaka, Poopó.

The effects of mining contamination were not unique to these municipalities and communities. CORIDUP members belong to different municipalities (besides the two for this study), and therefore their experiences differ since they have other mining companies such as the Kori Chaca (an open pit mine that belongs to the Inti Raymi mining corporation) and Kori Kollo gold and silver mines, polluting their water (Catapa, n.d). Nevertheless, during the CORIDUP monthly meetings, comunarixs and residentes shared similar experiences and perspectives about the causes and effects of the contamination of waters. Doña Elena, 68, is a former Jilakata (another name for the maximum indigenous authority) of the Sorachico Ayllu that is located only 40 minutes outside the city of Oruro and this Ayllu has been contaminated by the Kori Chaca gold mine since the 1980s. On the effects of mining contamination, Doña Elena shared: 
There was a comunaria here, she was very sick, and people here don't get sick, they are strong. But then we found out she was drinking water from the river. One day she got really sick after drinking the water and then she died... the animals also drink [the water from the river] and then they died. If they don't die, then their hooves peel off and fall apart.

These complex situations translate into people, particularly indigenous campesinx women, having to find new sources of water, frequently by traveling longer distances within and outside their communities. An example is the comunarix in Figure $\mathbf{1 2}$ who is traveling two hours walking to the nearest town to get water. People from Quellia and Puñaka travel to the Poopó town, and people from Kochi Piacala and Alantañita travel to the Machacamarca town to buy clean water. Sometimes people travel to Oruro city, which is double the distance from the main towns. They do this when they have other errands to run there. Since many have relatives or acquaintances in these towns, they get water there for free. Doña Victoria, 49, from Quellia, Poopó explained:

You have to find a private car that will bring you water. They charge between bs.30-50 [\$US 4-5]...this water is for your own consumption, but for washing clothes you have to use that [contaminated ] water because you can't pay bs. 30 every time. Here water is a luxury [emphasis added].

Other times comunarixs coordinate with residents to bring water for them, such as in Figure 12 where a comunarix got help from a residente to get water. Comunarixs still pay for water and for its transportation, but as Doña Paula explained, "at least we do not have to worry about finding a car or motorbike, a driver and the gas." These logistics 
might seem unimportant, but in the context of these communities, where only few people have access to these assets, they become significant obstacles. Since Alantañita is closer to Machacamarca (45 minutes walking), people usually walk and get water from friends or relatives, or they buy it from their neighbors at bs. 10 (\$US 1.50) for a 20 -gallon jerry can. In Kochi Piacala, people pay around bs. 20 (\$us 2.50) for transportation, plus another bs. 15-20 (\$us 2-2.50) for a 20-gallon jerry can. The Poopó communities pay similar amounts, except that participants in Poopó pay between bs.30-bs.50 (\$us 3-5) for transportation.
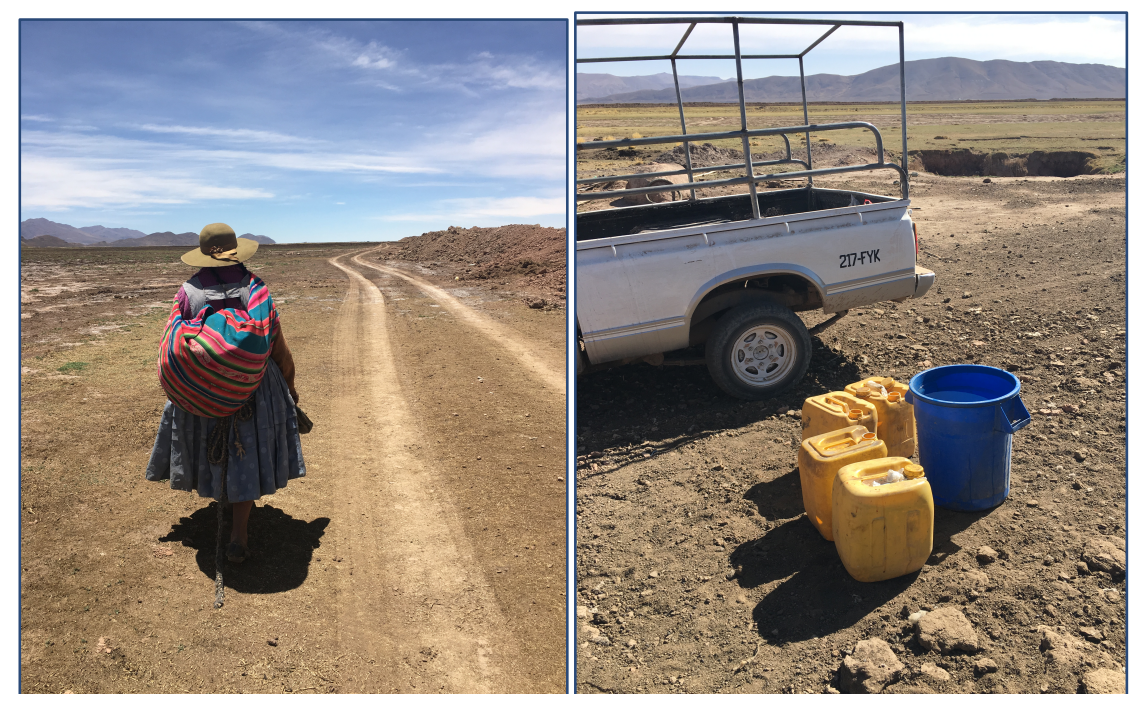

Figure 12. Getting water in the Machacamarca municipality. Photograph by the author.

Furthermore, within their communities, women have to travel longer distances to obtain water. Doña Paula usually wakes up around 5:00 am and her first activity is to bring water from a nearby waterhole (20 minutes walking distance back and forth from her house). This water is contaminated, but is not greenish and funky like the water from wijiñas, therefore she uses this water to wash dishes. The water she buys from 
Machacamarca (two hour walking distance) is for her and her husband's consumption only, which includes cooking, drinking, and some minor hygiene activities (washing hands and face). She takes her and her husband's clothes to Machacamarca to wash them. Doña Paula is a subsistence campesinx; she and her husband have around 100 sheep, 24 cows, a pig, six piglets and two shepherd dogs. Every day therefore revolves around finding clean or less contaminated water sources for her animals. She told me that 10 years ago, she could still get her animals' drinking water from a river near her house, about 15 minutes walking. Now she has to walk further in search of clean or cleaner water. After taking the sheep to grass in the early mornings, Doña Paula and I would leave her house around $11 \mathrm{am}$, along with the cows, sheep, and her shepherd dogs, and come back around 6:30 pm. We would take enough time for animals to stop and eat the little, dried yellow grass around her fields and then go to a river in the vicinity (approximately 1.5 hour walking) where the water did not seem contaminated, or as contaminated, and her animals would be able to drink it.

The lack of clean water also has direct consequences on everyday living activities, particularly on those activities that women partake to meet basic needs, such as washing clothes, cooking, or washing dishes. Figure 13 shows two comunarixs from the Machacamarca municipality cooking, which they do with the little water they get from the Machacamarca town. Doña Amalia, 35, a Mama T'alla from Quellia, Poopó described, "this affects women, yes, first because we cook; when you use that [contaminated water], food is very salty, so we had to change our seasoning and many times we cannot cook at all.” Doña Amalia is originally from Qaqachaca, another 
indigenous community in Oruro that is in close proximity to Potosí and which does not have mining activities nearby. During my interview with her, Doña Amalia compared and contrasted the different realities for these two indigenous campexinx communities:

In my community [Qaqachaca] we produce everything, and there is a lot of animal production too...we have irrigation, the water flows, so we have habas, corn, wheat, grains, anything you put on it [the soil], fruits, vegetables, anything grows...[in contrast]...when I got married and moved here [to Quellia], I was very excited about growing crops, but this [soil] produces nothing. Here everything is dried, I put fava beans, grains, nothing [grows]. I taste the soil and it is salty, the water is also salty. I asked why? And my husband told me the soil was contaminated and at that time I didn't know what contamination was or what it did. But now I know.

Doña Marcela, 60, from Quellia, Poopó echoed an analogous reality: "When you wash your clothes with that [contaminated] water, they dry up as if you would have put salt on them, they become white, you shake them off and something like saltpeter comes out." In Machacamarca, water seems to have a different effect on clothes, as Doña Paula described: “This [contaminated] water doesn't wash anything, my skirts become black, that's why I take them to Machacamarca." Regarding water usage for hygiene, Doña Laura, 53, a former secretary of finances for the Caravi community and a CORIDUP leader, explained: "Even for hygiene water is important because we have little water, so we can only rinse the dishes, not wash them, the same for our bodies, so with all of this, the women are the ones suffering...we have to manage water for hygiene, that clean 
water has to last for everything." The World Health Organization (WHO) recommends between 50-100 liters of water per day to meet the most basic needs of individuals and to avoid health-related concerns. Participants like Doña Paula, 67, or Doña Jazmin, 50, from Kochi Piacala, mentioned that they use approximately four-five (20 gallon) jerry cans with water per week (around 300-380 liters a week). In comparison, the nationalized Huanuni mine consumes approximately 28 million liters of water per day (Gruberg \& Andreucci, 2015). This makes the Huanuni mine the mining operation in Bolivia with the second highest consumption of water. The first is the open-pit mine at San Cristobal that extracts silver, lead and zinc in the department of Potosí ("Hirano: Minera San Cristobal”, 2018).
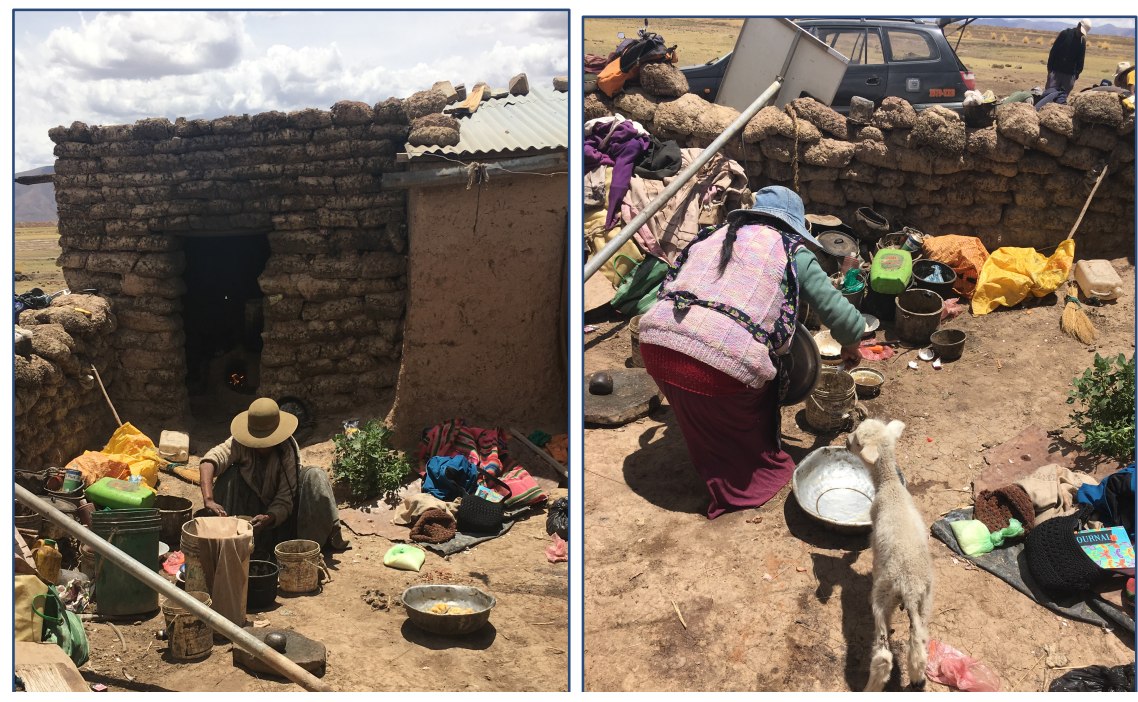

Figure 13. Water and daily activities. Women in Kochi Piacala and Alantañita cooking and washing dishes. Photograph by the author.

Reflecting on how the lack of access to clean water affects their lives, participants concluded that water is the principal factor forcing people to migrate. Doña Laura, 52, is 
a CORIDUP member from the Caravi community. She explained, "the well [in my community] is completely salty and bitter, undrinkable, it smells like rotten minerals, so our only option is to migrate to the city, or to another country. If this region was productive I think people would stay, but it is not, so people have to look for their future.” Describing a similar reality in Machacamarca, Doña Jacinta, 57, from Alantañita shared:

The communities that have [clean] water are standing up, they are producing [crops], and they are good. We get their crops, so their children are not leaving, they are creating a future, but here we are not, our children could do the same but they can't, so they have to leave."

In other words, as Doña Teresa, 38, from Alantañita, Machacamarca explained, "sin agua no hay vida [without water, there is no life]..." (Emphasis added).

\section{3. Summary}

In this chapter, I described participants' perspectives and experiences on how neoextractivism affects their lives. The literature review on this topic suggests that neoextractivism has the same socio-environmental effects as classical extractivism, and participants' stories attest to this. These communities have experienced an ongoing rural diaspora to urban centers for different reasons: droughts, the state's lack of support for agrarian economies, lack of crops, sick animals, and general trend of rural-urban migrations among others. According to participants, however, mining contamination is the main reason for their exodus. This rural diaspora has created a condition known as the double residency. This concept refers to the situation where people (called 
residentes) migrate and live in the urban centers while still having lands in their communities of origin and therefore keeping a connection to them, either by going back to their communities a few days a week to take care of their lands or by participating in community leadership roles. Those few who live in the communities permanently are called comunarixs.

While mining contamination has been a centuries-old issue, participants argued that contamination of waters and soils increased around the 1980s, thus making migration more pronounced. Mining contamination however does not only create an exodus but also the impossibility of a return. The recent international boom in quinoa's demand since 2013 has motivated people to go back to their communities to harvest it, creating a vibrant communal revitalization in rural Bolivia. This, however, is not the case for the communities of this study. They traditionally harvested quinoa but have not experienced this revitalization because their soils are too contaminated to produce most crops, including quinoa.

At the epicenter of these issues is water, which underwrites all of the reasons participants mentioned for leaving their communities. Participants have little to no access to clean water near their homes, which affects all of the minor and major activities of their lives. For indigenous campesinx women, water is central for most of their daily activities such as cooking, cleaning, feeding livestock, watering crops, and feeding themselves. This means that the participants who stay in their communities have to travel longer distances, such as in the case of Kochi Piacala where people have to walk two hours to the town of Machacamarca to obtain clean water or pay for someone to bring it. 
Indigenous campesinx women are subsistence producers and also social reproducers (they take care of children and family), which translates into them bearing the brunt of contamination produced by the extractivist sector.

These harsh realities have resulted in mobilizations led by CORIDUP demanding better environmental regulations. These mobilizations started in 2006 and as participants described, they had high hopes. Evo Morales was elected president of Bolivia the year before, 2005, and participants expected that Morales, someone with the same background as them, would support their cause. The next chapter describes participants' experience with the Morales government and their struggle against mining contamination. 


\section{CHAPTER FIVE}

\section{THE STATE AND NEO-EXTRACTIVISM, A LOVE AFFAIR}

On September 26, 2018, a day after the United Nations Security Council meeting, I scrolled through my Facebook page for some news and gossip. The many posts praising President Evo Morales’s fiery UN speech against Donald Trump surprised me. "Thank you Bolivia for sharing your wise and courageous leader," someone commented online. Morales was very critical of Trump's foreign policy, and he framed his criticism within the context of a long US history of supporting, many times engineering, coup d'états against democratic governments around the world, such as the overthrow of President Salvador Allende in Chile in 1973. This criticism became more relevant considering the potential threats of a US military invasion of Venezuela. Morales also touched on Trump's shameful immigration policies at home, including the practices of separating families and placing immigrant children in cages. This speech resonated deeply with my political standing as a Bolivian immigrant living in the US. I would have found it inspirational, except for the fact that most people I had recently interviewed for this study described Morales as a falso conejo or fake rabbit- a witty reference to a Bolivian dish that does not look or taste like rabbit. In other words, significant contradictions have emerged between Morales' anti-imperialist and anti-capitalist discourse and his economic and political practices in favor of the extractivist sector. Under Morales, extractive capitalism (including minerals, natural gas, and soy) has expanded more rapidly than under any previous neoliberal governments (Gandarillas, 2016).

In what follows, I present the testimonies of participants in this study about these 
ambiguities and how they affect their lives. Moreover, since the Morales government has to manage and reconcile extractive capitalism with indigenous self-governance, participants revealed that it does so by using four main mechanisms for taming dissent. These mechanisms include:

1) A legal framework that appears to support the rights of indigenous communities and the environment, which ironically the Morales government has used to bolster the rights of the mining sector, particularly over the rights of indigenous communities. The Bolivian state also uses this legal framework to strengthen its role as the decision maker over natural resources.

2) A fiery rhetoric of ethnic inclusion and political participation, reflected in the high number of indigenous politicians and leaders in the state administration, alongside ongoing government-perpetrated class-based discrimination towards poor indigenous campesinxs.

3) A complex divide-and-conquer strategy based on (existing and new) class, race, party affiliation, and territorial divisions that is used to seek approval for resourceextraction projects. This strategy is intricate and at times creates both a conflation and separation between groups. If communities are able to overcome such contradictions and divisions, then they face a fourth mechanism:

4) Debilitating bureaucracy: To achieve their demands, they must face a complicated, tedious, and deliberately time-consuming organizing process, which contributes to a decrease in dissent and co-optation of social movements.

The following paragraphs describe these four mechanisms in more detail. I give priority 
to presenting participants' accounts as they emerged in my interviews and when necessary, I present findings from the literature review that supports these claims.

\section{1. The legal framework of contradictions}

"When Evo became president we had a lot of hope," shared Don Miguel, 67, about his expectations of Morales's government. In the chapter about data and methods I mentioned that Don Miguel is a residente of the Kochi Piacala community. He moved to the city of Oruro 30 years ago, where he works with leather, but he still has a parcel of land in his community and is very well connected to it through the various leadership roles he has held. Don Miguel is also a former CORIDUP president and vice-president. Like other leaders I met in this area, Don Miguel is very shy and humble in his demeanor, yet his soft-spoken tone does not hide the strength of his character.

As Don Miguel described, Morales was the first indigenous president of a predominantly indigenous nation (he was born in the rural village of Orinoca Oruro), and it was also the different actions he engaged with, such as being a coca farmer activist that signaled significant changes. La Nueva Constitución Política del Estado, or The New Bolivian Constitution (CPE), drafted in 2009, is often view as an inspiring document and it is considered, together with Ecuador's, one of the "most radical constitutions in the world" (Lalander, 2014, p. 150). At its core, the CPE provides a solid strengthening of the rights of indigenous people, as well the rights of nature and the environment. Beside the approval of the new CPE, there was also the creation of many pro-environmental and pro-indigenous decrees and laws that gave the impression of real change. As Don Lucio, 55, a lawyer from CEPA described: 
What is Morales' discourse and project about? The protection of Mother Earth, the rational use of natural resources and to have made his regime one [of] the most complete judicial systems with [the creation of] for example Law 300 about Pacha Mama, Law 410 that makes water access a central issue and Law 45 against racism. I am thankful to this regime for these norms and laws.

Law No. 300, the Law of Mother Earth and Integral Development for Living Well (Sumaq Qamaña or buen vivir, referring to the indigenous philosophy of balance with nature), made world news when it was approved in 2010 since many considered this law one of the most progressive environmental decrees in the region and perhaps in the world. This law made Morales the apparent guardian of environmental and indigenous rights worldwide. Nevertheless, participants pointed out the contradictions between what Morales promised in relation to indigenous sovereignty and the environment compared with his unconditional support of the extractivist sector. To illustrate these contradictions, I juxtapose the scope, contradictions, and limitations of two incompatible laws: Supreme Decree 0335 and Mining and Metallurgic Law 535.

\subsubsection{Supreme Decree 0335 of 2009}

The Huanuni mine has been disposing untreated mining waste directly into the nearby rivers (Huanuni, Santa Fe and San Juan de Sora Sora) for nearly a century (Sanchez, 2009). This means that there is a severe accumulation of mining wastes and mining sediments, creating environmental liabilities for this region. However, communities around these rivers started feeling the heavy impact of mining 
contamination around the 1990s (Colectivo CASA, n.d). The Kochi Piacala community was among the first communities that denounced the impact of mining contamination in its waters. As the people I interviewed explained, the communities in close proximity to the rivers and Lake Poopó also started to denounce the contamination of their waters and soils. Before the creation of CORIDUP, these complaints were fragmented and there was not a cohesive outcry against the Huanuni mine or the government's lack of mitigating mechanisms. Doña Elena, 68, a key CORIDUP leader and Jilakata for the Sorachico Ayllu, described the process of community organizing:

In 2003, during a regional meeting of the Ayllus we started talking about this issue and we realized that to peck at particular problems was not having any effect with the government. We realized that it was better to be together, to be united, therefore the idea was born that all communities be represented by una sola organización de base [one single grassroots organization] and that's how the CORIDUP was born.

CORIDUP represents 80 rural communities across four municipalities of the Poopó basin. It was created in August 2006 and consolidated in 2007 through its first foundational congress where 200 community representatives participated (OCMAL, 2007). Doña Elena described the significance of CORIDUP as “...perhaps the first time that the communities [in this region] organized demanding environmental mitigations and protection for their territories." According to the UTO (Technical University of Oruro), in this department alone there are more than 300 mining operations, including small, medium, and large-scale mining companies, as well as community-based companies and 
mining cooperatives (CORIDUP, 2010). This shows the magnitude of mining activities in Oruro.

In October 2009, CORIDUP mobilized a rally to Bolivia's capital city La Paz to demand the approval of Supreme Decree 0335 (SD 0335), which declares the Huanuni sub-basin to be in a state of environmental emergency and mandates environmental remediation projects as directed by national environmental regulations (Horowitz \& Watts, 2016). Doña Elena further described this rally:

We participated in the meetings until someone, I think it was brother Felipe, proposed a rally, then we organized the rally to La Paz... we the women took care of the food, it was a lot of work but we were also very engaged; we participated in the discussions, we were tired but also happy thinking there was finally a solution to our problems.

Doña Elena also explained that the central actors of this rally were the affected communities (from Machacamarca, Poopó, El Choro, and Huanuni municipalities) and there were hundreds of them, with a high participation by women. When I asked why women were so involved, Doña Elena replied, “I don’t know, it was the momentum, although we didn't have money or time, we still participated; some hermanas [sisters] came with their wawas [Quechua word for babies] because we believed we could achieve something, also because Evo was president; he would support us, we thought."

Supreme Decree 0335 was approved that year and it is unique in its approach. Emergency decrees usually apply to natural disasters only. Moreover, this decree is not just about mitigation and remediation, but also about the "replenishment [of] 
environmental conditions for water, a natural resource so important and decisive for life in the Poopó basin" (CEPA, 2009, p. 6). As Horowitts and Watts argue, this law signaled "a potentially important shift in the Bolivian government's approach to mining, which historically has been permitted to operate with little oversight and scant regard for social and environmental impacts" (2016, p. 103). ${ }^{56}$

One central mandate of SD 0335 was the creation of the Huanuni mine's tailing dam, which, although it would not have stopped contamination of waters and soils, would have decreased it substantially. Participants highlighted the fact that neither SD 0335 nor CORIDUP ever demanded the closing of the Huanuni mine. What they demand is more environmentally responsible mining practices. When I heard this, I was struck by how moderate they were in their demands, especially considering that the Andes and the Huanuni region in particular are known for a vibrant history of radical movements. But as participants stressed, many people within their communities and Ayllus are miners who have families to support just like them and they also pointed out that life as a campesinx is extremely difficult. Therefore, they understand the need to work. Consequently, what CORIDUP and SD 0335 called for is a more responsible way to do mining to protect the environment and the people. According to Don Lucio, 55, the lawyer from CEPA in charge of drafting SD 0335:

We wanted Oruro to be an example for our country; we wanted to show that contamination could be stopped, that a different type of mining is possible,

\footnotetext{
${ }^{56}$ SD 0335 identifies six general lines of strategy, which it links with specific actions and projects to help with mitigation processes and projects. These strategic lines include: 1) Mitigation, treatment and environmental control of mining pollution of the Huanuni basin; 2) Conservation of the natural resources of the Huanuni basin; 3) Basic sanitation to improve quality of life; 4) Environmental education and capacitation to improve activities in the Huanuni basin; 5) Environmental health services to the Huanuni basin population; 6) Management of the effects on the population of the basin (CEPA, 2007).
} 
and we want to make sure that this law did not affect the miners, who are part of the state and who are part of our department.

Moreover, as Doña Victoria, 49, from Quellia, Poopó explained, “quien contamina, paga [he who contaminates, pays for the damage]." This ruling comes from the Bolivian environmental regulations of 1992 . However, as stipulated in SD 0335, while the mining companies should pay for any and all social and environmental damages to the communities, the government is charged with the enforcement of this decree. Specifically, the ministries responsible for the implementation of SD 0335 are the Ministries of Defense, Environment and Water, Rural Development and Territories, and the ministry of Planning and Development (CEPA, 2009).

In spite of all the promises behind its enactment, the impact of SD 0335 has been minimal at best, leaving communities disenchanted with the government, and also idle. For one thing, according to the timeline of SD 0335, the Huanuni mine's tailing dam should have been finished by 2011 (as of April 2019, the tailing dam is not in operation). Don Miguel, 67, reflected on the disillusionment:

We had a lot of hope but the deception was big since we received no support. He [Morales] signed the decree but just that. We forced him to sign the decree with a rally, but he has not yet implemented any policies related to environmental issues. He has given a lot of support to miners and cooperativists. He has preferred to gain money rather than to take care of Mother Earth.

The government shirked its responsibility for enforcement and implementation, and 
transferred all responsibilities regarding SD 0335 to Proyecto Cuenca Poopó (Poopó Basin Project or PCP). In 2010, the European Union granted 14 million euros to the Bolivian state to support projects aligned with the objectives of the Millennium Development Goals in the Poopó basin. PCP, however, had no stipulations regarding SD 0335 (Vazquez, 2017). The bureaucratic process of project operations in Bolivia delayed the PCP implementation until 2012-2013, which aligned with the implementations of the SD 0335 strategic lines of action. Local and regional state authorities instructed communities within SD 0335 to redirect their petitions for mitigation projects to PCP, although it was clear that PCP had made no agreement to prioritize such communities. As a result, contaminated communities stopped their pressure-based tactics against the state, such as rallies and protests, in hopes of receiving some benefits from PCP. Nevertheless, most if not all of the contaminated communities were unable to receive any support. This happened because there was no clarity regarding responsibilities: who should demand projects from PCP: The affected communities? Local government officials? CORIDUP? To illustrate, in 2016-2017 PCP created two positions for environmental health in the Machacamarca and Huanuni municipalities. Ostensibly, these positions were a result of SD 0335 's strategic line four that requires the creation of such positions. But in reality, these two positions were funded with PCP resources, and any attempt to use these positions to further the goals of SD 0335 was left entirely to the initiative of the two people hired to fill them. Leo, a member of Catapa (a non-profit Belgian environmental organization working in Oruro and in charge of supervising the implementation of PCP) explained during a presentation to CORIDUP: 
The reality is that no government entity took responsibility of SD 0335 , but rather they pointed to PCP, although PCP says nothing in its framework documents about this decree, and the problem is that "quien más pide más recibe, no quien más lo necesita" [the ones that demand the most receive the most, not the ones that need the most help].

Leo explained to me that the problem with the government and top-down approaches such as PCP is that they are not distributed based on needs, but on demand. Because many of the communities within CORIDUP had experienced intense emigrations, they lacked the management capacity to organize and present specific projects within their POAs (Annual Operating Plans) to receive any benefit from PCP. It is also worth mentioning that for many public projects, the government requires that at least 24 families benefit from POAs, which is impossible to fulfill for communities that experienced a high out migration. On top of this, it was unclear who was responsible for drafting and demanding projects for the communities. According to SD 0335 it is the government, yet the government shook off any responsibility and instead focused on taming dissent. As a result, communities stopped their anti-mining activism and received no reparations from mining contamination. Don Luis, 48, the director of operations from CEPA, explained the ambiguous role of the state:

What has the government done these years? We have seen an absence of the State in the control and audit of mining activities, and the same happened with the decree [0335]. In other words it [the state] says 'you the people figure out what to do, you fight, you argue with the mining sector,' when in reality the 
state is the entity that should make the rights of the people prevail and the

rights that we Bolivians have to decide over natural resources.

\subsubsection{Mining and Metallurgic Law No. 535}

The Mining and Metallurgic Law No. 535 (MML 535) created in May 2014 (to

replace Law 1777 of 1997) is an extensive law that contains 234 articles. MML 535 was

drafted over three years with the participation of small-and large-scale, national and

private sectors within the mining industry (Suarez y Suarez, 2014). Although its original

purpose was the complete nationalization of the mining sector, MML 535 continues to

favor the private sector, both national and international.

Table 6. MML 535 and six articles relevant for this study

Article 1: (Objective) This present law regulates metallurgic and mining activities by establishing principles, guidelines and procedures for the granting, maintenance and execution of mining rights, development and the continuity of mining and metallurgical activities in a responsible, planned and sustainable manner.

Article 2: (Control and ownership rights of the Bolivian people) Mineral resources, irrespective of their origin or location in the surface and subsurface of the territory of the state are of property and direct, indivisible and imprescriptible ownership of the Bolivian people; their administration corresponds to the State

Article 99.I: (Rights to security and judicial protection) The Plurinational state guarantees legal security to mining entrepreneurships, investments and holders of mining rights legally established and dictates that, among other rights, they have the right to demand of the competent public authorities full and effective protection against acts of individual or collective persons who seek to prevent or impede the effective exercise of mining rights.

Article 99. II: Individuals or collectives of people that perform acts that impede the exercise of holders of mining rights will be subject to the penalties established in these regulations.

Article 113. I: (Pre-constituted rights) Mining rights acquired prior to the publication of this law, when appropriate, obtained by whatever forms provided in the former mining legislation, on surface areas of any domain or nature, constitute pre-established and acquired rights whose continuity is guaranteed, at the request of the involved party in the respective administrative contracts.

Article 113. II These rights include those acquired under any legal title, prior to the granting of TCOs (Communal Territory Lands) and its change to TIOCs (Indigenous Territorial Communal Lands) in agreement with the agrarian and autonomous legislation (Source: App Gaceta Bolivia, 2014). 
As stipulated in MML 535, mining activities are supposed to be carried on in a "responsible, planned, and sustainable manner" (Article 1); for the wellbeing and development of "the Bolivian people" and administered by the state (Article 2) (App Gaceta Bolivia, 2014). In the same breath, however, and seemingly annulling Articles 1 and 2, MML 535 gives unconditional rights and protection of private property rights to the mining sector. Specifically, articles 99, 113.I and 113.II, give mining concessionaries full security and legal protection to carry on mining activities, while simultaneously criminalizing any action that might disrupt them (Villegas, 2014). This criminalization includes not only those protesting against the mining sector, such as the CORIDUP communities, but also those who might strike from within, such as peones (lowest paid and informal miners). Additionally, the phrasing of MML 535 places the rights of mining concessionaries above those of TCOs (Communal Indigenous Territories) and above the Bolivian people's collective rights (2014). As Tania, 28, from the collective explains, "the mining law [535], as you know, was drafted by members of mining cooperatives, and they live inside their heads, within a strong colonialist and capitalist logic even when they come from rural communities, so that's a big contradiction."

Doña Tamara, 38, from Alantañita, Machacamarca, a community that is among the most contaminated by mining pollution, expressed the following discontent:

With the mining law [535], politics have worsened. They [the miners] control all access to the water, they monopolize the rivers, and do not even look at the communities. What has Evo done? Nothing, he has done nothing to protect the 
campesinxs. At the same time he flirts with the miners.

Most of my community informants did not point specifically to MML 535 as the epitome of the government's alliance with the mining sector. Many of them were unfamiliar with the general stipulations of this law, but they held a common perspective that the Morales government has a cozy and convenient relationship with the mining sector. Sabrina, 37, from the Wasi Pacha collective, gives a remarkable analogy for the relationship between mining companies, the government and communities:

Mining is like an illusion. It is like having a tenant in your house; you rent your house but the tenant has more rights than you, he comes, pays rent but destroys your house and the state is the one that allows for companies to do this, it allows them to enter into our territory so we become a rentier country. It is easy, you rent, you get paid but at the end what do we gain? Nothing, but we lose our house.

It is telling that Sabrina uses this analogy to illustrate the state's rent-seeking behavior and short-term economic gains that ignore the long-term consequences of environmental and social damage, since this was a major finding of the literature review for this study.

Doña Elena, 68, was not only one of the CORIDUP leaders involved in the approval of SD 0335 , but she was also among the groups of people involved in the new constituency assembly that helped to draft the new Bolivian constitution (CPE) in 2006. Doña Elena is from the Sorachico Ayllu located near lake Uru Uru, 40 minutes outside of the city of Oruro. Her Ayllu has been contaminated since 2003 by the Kori Chaca gold 
mine that is located only five kilometers southwest of the city of Oruro (Catapa, n.d). She explained that her community had to fight for their compensatory rights because under the current law (MML 535), only communities within a two-kilometer radius (1.25 miles) from mining sites are considered for compensatory projects. The mine company's manager had argued that her community was outside this radius.

Doña Elena occupied many leadership roles, including that of Jilakata, maximum indigenous authority, of her Ayllu. She now lives by El Puente Español, 30 minutes outside the Oruro city and owns a small house with many dogs; I counted at least five, which are the shepherds for her sheep and three cows. ${ }^{57}$ Her house's walls are also full of diplomas memorializing her participation in numerous workshops and classes, which attest to her leadership character. At the CORIDUP meetings, Doña Elena was always outspoken and knowledgeable about the issues discussed. It was perhaps all the workshops and classes she attended, and also her lived experience with the effects of contamination that gave Doña Elena an articulated and critical view of how extractivism operates. Nowadays Doña Elena is not as involved as she used to be, since a few years ago she developed an illness in her legs that impedes her ability to walk long distances. According to Doña Elena, her illness is a result of copagira, because many times, while grazing her animals, she had to walk barefoot through the contaminated river that is right

\footnotetext{
${ }^{57}$ Doña Elena was able to obtain her house as part of a government project called Bolivia Cambia, Evo Cumple [Bolivia changes, Evo fulfills his promises] that provides housing to impoverishing communities. Nevertheless, as she was quick to point out, the house was not free. Most government projects demand a contraparte, or counterpart, meaning that people or communities have to give their own contribution to the projects either by buying their own construction materials or by providing the manual labor. According to Doña Elena, she had to cover $60 \%$ of the costs of her house. Therefore, she stressed that such projects are not free, as the government claims. On the other hand, other participants such as Doña Jazmin, 50, from Kochi Piacala perceive this demand for a counterpart as the government willingness to compromise. She criticizes comunarixs for expecting everything to be handed to them and for not taking advantage of such opportunities.
} 
outside her house. While she was busy cooking food for her family and dogs, Doña Elena shared the following comments about her own experience as an organizer in support of Morales:

Since the very first moment he [Evo] allowed the miners to work, and now there is no tailing dam... he says nothing about it, but he also says we have to take care of Pachamama, but I question that. How can we take care of her [Pachamama] with all those mining contaminants? It is impossible... and all is the same thing... I don't know why he [Evo] acts like that, he says one thing and does another. Many times we asked to meet with him, to talk with him, we sent many letters but he never replied, he does not want to face us, but for the miners he does everything... When I saw him many years ago, I screamed 'brother Evo, why are you punishing us?' We were very involved with the new constituency assembly, he achieved that because of us, but now he shakes hands with the miners and the k'aras' [white or light-skinned people]...He [Evo] said he would not allow anyone to contaminate Pachamama, he said that, right? But instead he has shaken hands with the miners, with the cooperatives, but not with us. ${ }^{58}$

Based on this and other accounts, it is possible to conclude that while the Morales government has created a legal framework that nominally supports the rights of indigenous communities and the environment, with SD 0335 as a quintessential

\footnotetext{
${ }^{58}$ Pigmentocracy, or a hierarchy based in skin tone, regardless of race is still prevalent in Bolivia. Pigmentocracy is also related to class, since the higher the social status a person has, the lighter their skin tone. In this sense, although I did not ask Doña Elena directly, by saying $k$ 'aras, I think in this paragraph she is referring to Morales's extremely friendly relationship with the mining company's managers, who are light-skinned, as well as with the agribusiness elites of the lowlands, who are usually light-skinned.
} 
example, this legal framework also signifies conflicting interests and priorities for the government, exemplified through MML 535 (Villegas, 2014). As a result of such contradictions, participants in this study question the true intentions of the Bolivian state and its cozy relationship with the mining sector.

\section{2. Ethnic inclusion}

All this study participants shared a critical perspective on the contradictions between Morales' discourses and the actions of the government he leads in relation to the mining sector. Simultaneously, the majority of them also recognized the progress brought by the Movimiento al Socialismo [Movement Towards Socialism] or MAS government that Morales leads. I have already presented some of participants' positive views about the progressive laws created under Morales, such as Environmental Law 300. Other participants like Doña Silvia, 51, from Puñaka, Poopó, brought to my attention the redistributive projects that rural, indigenous, and impoverished communities see as signals of progress: "With Evo, now rural communities have their own little houses, with at least a room, a bathroom, and a kitchen. Before we had nothing. We would have only one room with mud ovens inside, so everything was full of smoke, poor people suffered a lot and now I see that they live better and they seem happier.” Comparing Morales' government with previous ones, Doña Patricia, 43, from Quellia, Poopó reflected:

Older people in my community say 'he [Evo] is from here, even if he is stealing money, he is doing that for us...before we never had a house, before we never had any access to water, we never had anything in the countryside, 
nobody remembered us, when did any president come to our municipality to visit us? Nobody came, ever, except brother Evo'.

Since Morales became president in 2006, there have been many projects directed at poor and indigenous communities. Doña Jazmin, 50, from Kochi Piacala, Machacamarca mentioned the following with abundant pride:

The MAS has built tinglados and canchas de futbol [shed structures for community-oriented activities and soccer fields], as well as provided water and electricity to poor communities. He has helped poor people like no other president has, previous presidents have never took care of poor people.

Likewise, other participants referred to the tinglados and canchas de futbol as the exemplars of Morales' radical changes. In my trips across Bolivia, from La Paz to Oruro, Cochabamba and Santa Cruz, friends and family pointed out to these new structures in every small town and community we visited. These structures were easy to recognize due to their blue and sometimes yellow roofs and very green grass fields.

For indigenous campesinx women, gender equality and inclusion was another significant achievement of the MAS government. Doña Laura, 52, a former spokesperson for her community, Caravi, shared that although this inclusion of women as leaders, especially indigenous women, existed before Morales, With Evo, more women have become leaders under his presidency...Before men were machistas and now this has been reduced, there is more inclusion of women in organizations, more women have become Jilakatas; before only men could take this role, but now women walk side by side with men, there 
are now projects that are specific to women in rural areas, before there was nothing.

Similarly, Doña Silvia, 51, from Puñaka, Poopó reflected on her own experience as a leader representing MAS: "I was a councilor of the Huari city and I am thankful to Evo because he has given us, indigenous women, many opportunities. Before it was only the $k^{\prime}$ aras [white people] and men the only ones able to take government positions." This is a view that emphasizes the intersectionality of gender and race exclusions under other governments that allowed only white men to govern. Doña Jazmin, 50, from Kochi Piacala, Machacamarca, shared a similar view: "Before men were ahead of women, right? Evo then said women should be mayors, women should be authorities, and that's how in 2012 my community elected me as one of its leaders even though I was single."

Unlike Doña Laura, Doña Silvia and Doña Jazmin shared the view that such practices of gender inclusion should be exclusively attributed to the Morales' government since only under his presidency have such practices become commonplace. It is unclear whether this gender inclusion occurred due to Morales' policies or a general atmosphere in favor of gender inclusion. What it is clear, based on Doña Jazmin's testimony, is that in previous years, single women or widows were not allowed to hold any community leadership position. This was open only to married women or women in a formal union. Although this change might be perceived as gender inclusion, the single, widowed, or separated women in this study felt it was unfair. While married couples share leadership responsibilities (a Mama T'alla and Tata Mallku are usually a couple), when a single woman takes this role, she has to take care of all these responsibilities, time and resources 
alone, on her own.

"But honestly I see the president Evo as a father, I have the same origins, he was born like us, indigenous, he is a campesino, so I identify with him, and now I feel very proud. He opened the door for us, and he has worked for us like nobody has ever done," [emphasis added] expressed Doña Silvia, 51 from Puñaka, Poopó. With that phrase she captured the sentiment that all participants shared about Morales, that the biggest accomplishment of the MAS government is the ethnic inclusion and pride embodied in Morales' election as the first indigenous president of Bolivia, and which is maintained through the inclusion of indigenous people in governmental positions and the inclusionary sentiment that indigenous people feel. Her perspective makes even more sense considering that Morales was born in Orinoca, a rural village in Oruro from a family of campesinxs like Doña Silvia.

"Now for better or for worse, government officials have to deal with us; before they would shut the campesino's mouth, now they can't, now we know how to argue, how to fight. With Evo we learned to argue and stand up,” said Doña Jacinta, 57, from Alantañita, Machacamarca. Whereas 20 years ago the government was dominated by $k^{\prime}$ aras in black suits, now there is a diversity of people and attires, from colorful ponchos, mantas [indigenous shawls] to polleras [indigenous skirts]. ${ }^{59}$ Whereas before the Bolivian flag would stand alone outside the government palace, now there is the Whipala [indigenous flag] next to it, representing the plurinational identity of Bolivia. "On the

\footnotetext{
59 The indigenous leaders (male and female) I interviewed revealed to me that a mandatory indigenous outfit for indigenous leaders was established under the Morales presidency. Doña Karina, 53, from Poopó for example, explained to me that she usually wears pants and non-indigenous clothes. However, when she was a Mama T'alla in 2017, she had to dress with the traditional green and multicolor shawl, a hat and a pollera following the government's mandate on indigenous clothes for leaders.
} 
other hand, this is a government for the poor, only with this government we campesinos have received benefits, and let's be honest, you don't have to make a big study to see all the projects and the revalorization of culture," expressed Don Ramon, 46, a Tata Mallku from Puñaka, Poopó who was critical of Morales' stance on the mining sector. Similarly, Doña Laura, 52, from Caravi, Oruro, while sharing a critical perspective of the MAS government and its ambiguities with the mining sector, also shared the following: Before, el campesino was excluded from the cities. I remember I used to arrive here [to Oruro city] with my very dark skin, asi casi negrita [like this, with my almost black skin], and even my family would discriminate against me... but now [it] is different, indigenous people can walk on the streets, now young people want to be Jilakatas, now a campesino is the president of Bolivia, so yes, I think the mentality of people has changed for the better under Morales.

Remarkably, this view of ethnic inclusion and pride was shared across all the study participants, including those from CEPA, the two urban collectives and government officials. See for example what Tania, 28, a member and founder of the collective voiced:

I would have never imagined that we could talk about issues related to discrimination, of equal opportunities and that women are important; all of this has been possible with Morales's strategy under el proceso de cambio 
[process of change]. Now I feel empowered as a young indigenous woman, before you would never feel this way. ${ }^{60}$

By the same token, Don Lucio, the lawyer from CEPA in charge of supporting CORIDUP with the drafting of SD 0335, reflected on his own experience, "I must confess that I would like Evo to continue in power because through all of this time, I have learned to see and value my identity, now I see myself as Aymara....and I tell everyone who I am; before you could not say that, we were second-class citizens, but now this is different."

It is important to highlight that such efforts of ethnic inclusion represent a significant departure from previous historical government approaches and trends that were built on deep-rooted racial, ethnic and class oppressions and binary divisions to exclude indigenous Bolivians, who have always been the majority of the population. ${ }^{61}$ For an Anglo-American audience, the election of Evo Morales is analogous to the election of Barack Obama: an oppressed minority as president for a nation founded and maintained upon colonial and racist structures signaled the potential of momentous change.$^{62}$ Obama's promises came under the slogan of "change we can believe in", while

\footnotetext{
${ }^{60}$ El proceso de cambio, the process of change refers to the period that started before Morales' presidency, back in 2000 and 2003 with the social movements against neoliberal policies that have continued throughout the presidency of Morales. El proceso de cambio includes all the policies and projects aimed at making Bolivia a plurinational nation based on the philosophy of Sumag Qamaña or living well, as opposed to living under exploitation and oppression (Peralta, 2014).

${ }^{61}$ The 2012 census registered that 41 percent of Bolivians self-identified as indigenous. This represents a reduction from the previous census that registered 62 percent as self-identified indigenous. There are different and inconclusive explanations for such demographic change, including speculation about the MAS government's intention on this reduction to promote the expansion of extractive industries (Tabra, $\mathrm{n} / \mathrm{d}$ ). A common criticism of the census is in relation to the question about ethnic identity, which is very confusing "Do you self-identify as belonging to an indigenous, originary, peasant or afro Bolivian group?" Another criticism is that the census did not include "mestizos" [of mixed heritage] within this category, which is considered a proxy category for indigeneity.

${ }^{62}$ Here, my purpose is to compare only that which is comparable. Evidently there are few political economic resemblances between a world power like the US and a peripheral country like Bolivia. Here, my
} 
Morales's came under el proceso de cambio [the process of change]. Unlike Obama however, Morales did come from a rural and poor background as a campesinx himself, becoming a coca leaf farmer and a very charismatic union leader at a young age. Conversely, both presidencies experienced political unrests from the very people they claimed to represent. The Black Lives Matter movement emerged under the US's first African American president (Taylor, 2016). Similarly, the TIPNIS conflict emerged under Bolivia's first indigenous president.

Indigenous people in Bolivia have experienced structural discrimination from society, which did not end with colonialism. Indeed, not only was the colonial system reconstructed, it was also reinforced by founding the republic of Bolivia on its pillars, despite indigenous peoples representing a majority of the population. Therefore, the election of Morales as the first indigenous president and these inclusionary practices based on ethnicity signified a departure from racism and colonialism, or "so we thought," said Mario, 33, from the Wasi Pacha collective.

\subsection{1. "But...there is always a 'but' right?"}

In contrast to these sanguine views and experiences with the MAS government, not everyone attributed all the ethnic, gender and social progress exclusively to the government. Doña Patricia, 43, from Quellia, Poopó has been a water monitor for her Ayllu for the past four years. Although she now lives in the city of Oruro, she still has a parcel of land in Quellia, meaning she is a residente. She has received much training about water quality monitoring from different non-profit organizations and has become 
very knowledgeable about these issues. Right after Doña Patricia shared her optimistic views of Morales and his government, she also shared, "they [the government] have only built tinglados... and I don't agree...tinglados everywhere, we don't need them, people don't use them. Our main problem is water, that's what we need, not tinglados."

In a similar manner, Don Alex, the water systems supervisor for the Huanuni municipality, shared his view about soccer fields: "I feel sad to see that they are only giving band-aid solutions to the problems in el Altiplano, what we are fighting for is access to clean water. I am not against sports; however, I do not think a soccer field is going to fix any environmental issue.” Moreover, as Doña Jacinta, 57, from Alantañita, Machacamarca criticizes, "we are sad because after so many years there is still no projects for us, or for our soils." Crucially, the fact is that no project that directly focuses on the effects of mining contamination, or any project or action that stops mining's socioenvironmental effects, has been created in the communities that are part of this study. And more often than not, public projects are insufficient to cover the needs of these communities.

In February 2018 there was a meeting in the city of Oruro with CORIDUP and representatives of the Ministry of Rural Development and Territories (MRyT for its acronyms in Spanish). ${ }^{63}$ The purpose of these meetings (CORIDUP and government) is to discuss the environmental solutions mandated under SD 0335. Figure 14 shows CORIDUP and government officials in this meeting, which was held at Oruro's central governance building from 8:30 am to 2:00 pm. It had around 130 participants, 85 percent of them comunarixs and residentes and the rest representing the government or other

\footnotetext{
${ }^{63}$ This was a follow-up meeting to a previous meeting that CORIDUP had had in La Paz at the Comptroller's general of the State office, which I described in detail in the next section.
} 
related organizations such as CEPA and Catapa. The INIAF (National Institute of Agriculture and Forestry Innovation) within MDRyT gave a presentation about its national projects related to research, registration and promotion of quinoa seeds. While an agronomist from INIAF was giving the presentation, people started murmuring and the room soon became tense. Don Julian, a community leader from Kochi Piacala, Machacamarca interrupted the presentation, exclaiming: "What you are talking about is bullshit; we are tired of hearing about the same national projects. Once again you want to put your finger in our mouth [an expression that means misleading].” A Tata Mallku from Poopó followed up on Don Julian's outrage: "You are not talking about us, the affected communities, you are talking about things that are irrelevant for us. These papers say blah blah blah, but nothing about contamination...your projects are for virgin soils, they are not for these communities." I had heard these complaints before and they made sense to me. Giving seeds to campesinxs sounds like a great idea, yet when soils are contaminated and there are not clean waters, these seeds are useless. Doña Amalia, 35, a Mama T'alla from Poopó, captured the rage that she and the participants in this meeting felt about these national projects:

How dare you show us your photos about crops and those beautiful animals? We want to see our reality, not that fantasy... 12 years and the government has done nothing. Hermanos y hermanas, we are being cheated once more just because we are from el campo [the countryside], we have to be strong, and they have to give us their word like real men.

The same criticism was raised about the MiAgua I, II, and III government projects. These 
projects were created in 2011 as an initiative of President Morales to improve the living and health conditions of the population by increasing access and quality in provision of water services. These projects represent multiple approaches to increasing water access and quality, such as the construction of drinking water systems, sanitary sewer systems and irrigation infrastructures (MMAyA, n.d). ${ }^{64}$ Nevertheless, as participants in this study argued, it is useless for contaminated communities to have access to irrigation systems when the water is contaminated and/or there is no water (since the Huanuni mine captures most of it for its water-intensive procedures).

As mentioned before, a central component of SD 0335 was the construction of the Huanuni mine's tailing dam by 2011. The Huanuni mine is the main contributor to the contamination of waters in this region of el Altiplano, although not the only one, since there are also small-scale mining activities and cooperatives such as the Poopó cooperative (CEPA, 2009). According to a report from the Huanuni mine's manager in 2018, the tailing dam was allegedly almost completed but it is unclear when it will be functioning. For the community participants in this study, this just means this: "Somos el dique de colas de Huanuni" [we are Huanuni's mine tailing dam], a very common phrase that participants expressed during interviews and meetings. Wikipedia describes a tailing dam as an "earth-filled embankment dam used to store byproducts of mining operations" ("Tailing dam", n.d.). The tons of mining sediments accumulated downstream from the mine in communities such as Kochi Piacala and Alantañita or around communities of

\footnotetext{
${ }^{64}$ The program "MiAgua" I, II, and III is financed by CAF (Andean Development Corporation) and the American Development Bank. It promotes and supports the construction of small irrigation systems in order to increase agricultural production (CAF, n.d)
} 
Lake Poopó such as Quellia and Puñaka, make these communities literally the tailing dam of this mine and the trash dump of the Huanuni town. ${ }^{65}$

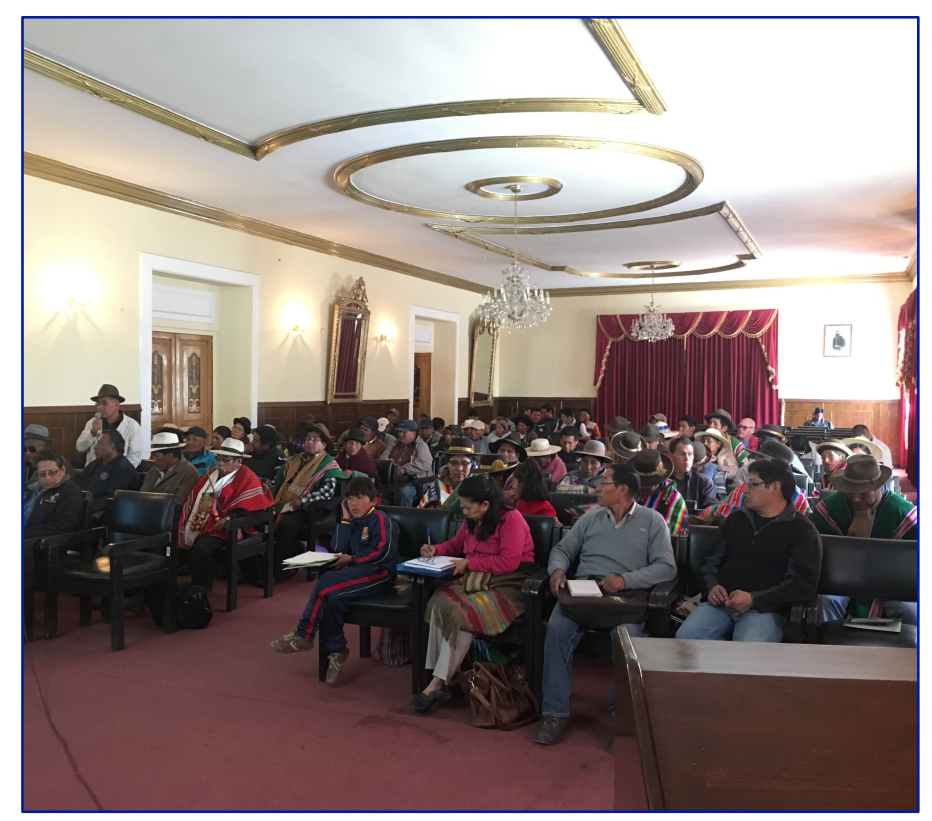

Figure 14. CORIDUP in a meeting with state officials. Photograph by the author

The lack of a tailing dam for the Huanuni mine also represents the leniency in enforcement of regulations by the government for public industries and/or the public sector, which for many participants was unsurprising. Don Fernando, 40, from Ticacala, Poopó offered an example of this bias: "The [private] Bolivar mine had a tailing dam, it would recycle its waters; they were a bit more responsible, meanwhile Huanuni [mine] is saddening." In my conversations with Bolivians, a majority shared the view that such leniency to state-owned companies gives way to corruption, such as the Banco Union scandal, due to lax regulations. In 2017, \$US.5.4 million dollars were lost from this state-

\footnotetext{
${ }^{65}$ The Huanuni river, besides carring copagira downstream, also carries downstream all the garbage that the Huanuni town produces. While traveling by motorbike to Kochi Piacala, I observed thousands of plastic bottles, mostly two-liter Coca Cola containers, spread throughout el Altiplano and around and within the communities in a sort of infinite landscape of plastic.
} 
owned bank, which is the third largest financial institution in Bolivia that supervises fiscal accounts (“El escandalo del Banco", 2017).

Regarding ethnic and gender inclusion, Don Miguel, 67, from the Kochi Piacala community, emphasized:

In the ' 60 s we suffered discrimination, but since the ' 80 s it started to change. So when Evo got in power things were already changing. Remember Palenque [a Bolivian politician] who had a woman of pollera with him in his party way before Evo? Even Goni [a former right-wing Bolivian president] had an indigenous person as vice president. In the government there is no indigenism, it is only a political gimmick to favor MAS politicians.

His view is intriguing, as it aligns with the literature on the emergence of multicultural neoliberalism as a strategy of ethnic inclusion around the 1980s throughout Latin America. According to this literature, while the state might use a multicultural discourse of ethnic inclusion and the promotion of indigenous rights, such discourse is allowed only within a neoliberal context that at the same time is used to deny those very rights to the most marginalized groups, including indigenous communities (Healy \& Paulson, 2000; Muelhman, 2009; Shah, 2007, 2010). Multicultural neoliberalism also promotes diversity and inclusion as long as such discourse and practices do not challenge or question the political and economic system. Mario, 33, from the collective, offered a different take on the government's approach of ethnic inclusion and celebration:

Another issue is the excessive folkloric show that the government makes with clothes, rituals, el pachamamismo [Pachamama-centrism] ...instead of connecting 
and reappraising indigenous traditions, people get tired, bored and disconnected from this... [I asked Mario to elaborate] Nowadays the Bolivian government over-uses indigenous rituals and indigenous symbols to show that it is indigenous. Yet in practice, this is a different story since such rituals have not translated into tangible progress and the contradiction is that now many indigenous people, especially youth, do not want to be associated with this type of performed indigenismo, or any indigenismo at all.

Moreover, male indigenous leaders I interviewed, challenged the view that Morales is the one and the only person capable of being president and of carrying on indigenous liberation. Don Aurelio, 48, from Puñaka, Poopó is Tata corregidor [Mayor] of the Puñaka Ayllu and he argued, "Morales is not the owner of our vision or what we envision, he is just a pawn, he is just a public image... when Morales leaves power our vision of ancestral indigenous communities will continue, that is a guarantee." Don Fernando, 40, from Ticacala, Poopó was a Tata Mallku from 2016-2017 of the Gran Tapakari Ayllu, which encompasses over 15 communities, one of the biggest Ayllus in the region. Don Fernando is also an oil engineer who has written two books about indigenous youth and indigenous cultural practices. Don Fernando argued that: Evo thinks he is the only one capable of being president, but that's not true, under the new constitution anyone, any Bolivian can be president, including myself...I am indigenous, educated, I can be president. So is Evo the only one capable of governing? No way... They [MAS] want us to believe they are the only ones, but that's not true. 
There are also the unintended (if also well-intended) consequences of progressive, inclusionary and ethnic-oriented policies. Agrarian reform was the central demand of the 1952 indigenous revolution because a handful of families owned the extensice landholdings known as latifundios. Under Morales, the new 2006 LRCA (Community and Agrarian Reform Law) was supposed to be a redistributive land reform from the land-rich to the land-poor (Webber, 2016, 2017). The new 2006 LRCA also extended the title of TCOs (Communally-owned Indigenous Lands) to the Andes. Before, such land titles belonged to the indigenous communities in the lowlands only. In parallel there is Law 247 that allows people to seize unused or unproductive lands. The results of these land policies have been mixed at best, and at their core these policies failed to create a successful land reform based on land redistribution. Landless and landpoor people, some connected to the Landless Workers Movement, benefited by getting small parcels of lands to build their houses (Webber, 2017). At the same time, as participants in this study attested, this has caused an increased looting of lands, particularly TCOs that are not continuous lands, but rather spread out and unconnected patches of lands (2017). As Doña Elena described:

"I think our [TCOs] lands are going to become houses, because if people do not produce, then others loot them. We don't have titles, so anyone comes with some fake papers and then they sell our land. Some leaders do this too, they take advantage and sell the lands. That's why I think the TCOs should be divided so comunarios y comunarias could take care of them and pay attention to this looting which is very serious here. [Emphasis added] 
Doña Elena is in effect suggesting that TCOs become minifundios, small properties of land, usually of five hectares or less which are typically used for subsistence agriculture. Minifundios have been a major territorial concern among Andean communities due to the lack of property rights and regulations in the region, which has led to uneven distribution of lands and the fragmentation of communal territories. When I was grazing animals with Doña Paula in Kochi Piacala, she complained that now that property owners have divided the lands, she has to walk longer distances to avoid trespassing on her neighbors' properties. She explained, "People get mad any time my sheep eat their grass, even though some of them do not use the lands." Moreover, agrarian reform under the LRCA and the New Bolivian constitution (CPE) recognize indigenous communities' sovereignty and self-determination over TCOs and their natural resources. At the same time, the new CPE and MML 535 (the new mining law) declare that the Bolivian state is the sole administrator of natural resources, even within TCOs. Doña Elena shared her indignation with this:

Doña Elena: The mayor told us that our lands are only Manka Pacha for us. Gisela: What is Manka Pacha?

Doña Elena: It means just a little above and just a little below the land, so our land is just the little above and below; what is deep inside [the land] is not ours.

Gisela: So who owns what is deep inside?

Doña Elena: The state owns everything, and I am mad because that means that in any moment they [the state] can kick us out. 
These accounts reflect the profound contradictions of what seem to be the wellintended policies of the MAS government to include and promote indigenous rights, particularly those rights related to territories, the environment, and indigenous autonomies. While ethnic inclusion and indigenous traditions of communal land ownership should be respected and even celebrated, a careful look shows how such naive support might create worsening scenarios for the very people that are supposed to benefit from it. Moreover, although not within the scope of this study, it is also important to mention that land reform under Morales has benefit extensively the agrocapitalist sector in the lowlands, particularly soy and coca producers (Webber, 2016). There is, however, another contradiction that has even worse repercussions for the indigenous communities in this study. This is the paradox of feeling included within the new Bolivian nation as indigenous people, while simultaneously being excluded as campesinxs.

\subsubsection{From ethnic inclusion to class exclusions}

Racism is deep-rooted in Bolivia's history and it is epitomized by the fact that although it is an indigenous majority nation, our first indigenous president was elected just a decade ago. Some perspectives mentioned above celebrate Morales's achievements, particularly those related to ethnic inclusion, as they seem to challenge the racist roots of the Bolivian society. Other perspectives offer a critical view of such achievements. There is however, a third perspective: study participants talked about a concealed discrimination by the Morales government, based on their class status as campesinxs. 
Doña Paula, 69, from Kochi Piacala, Machacamarca captures this succinctly: “There is no improvement for us, only for the rich [people]; for us there is no help."

The first time I heard this perspective about class discrimination towards indigenous peasant communities was during a monthly meeting of the Alantañita community. These types of meetings are usually held not in the communities but in the nearby towns of Machacamarca and Poopó. These meetings last from four to eight hours or more (the last meeting I participated in was in the city of Poopó and it started around 8:00 pm and finished around 2:30 am). The range of issues is broad, from interpersonal disputes to access to public projects. These meetings always started with El Akullico, the sharing of coca leaves to chew that symbolizes connection among those present, which also comes with a glass of Coca Cola, and then greetings in Quechua from the community leaders, to then carry on the meetings in Spanish. Participation by community members is all-encompassing, meaning that it is not just leaders monopolizing the conversation, but most of the people present in the meeting participate. During this meeting, an indigenous campesinxs woman mentioned a shared sentiment from participants in this study: "I feel we have been forgotten, we are pressured to participate and support the Mayor and yet we are still in the same situation. We are poor but it does not mean we do not exist; where is the solution to our territories? Nothing has been done because we are poor." Doña Victoria, 49, from Quellia, Poopó also expressed her frustrations during my interview with her:

The government looks out for its own interests only, and that means mining. It is only words when it says 'I work for the poor people, I work for the 
campesinos.' In practice it is not like that. Especially in my community in Poopó, we have seen nothing. It has left us aside. With this government I can't survive either as a campesina, farmer, or small trader. The government does not protect us... before I used to support Evo, I thought 'wow, un campesino como nosotros [a peasant like us] is going to make changes' but nothing, nothing for me and my community.

Particularly central to this problematic were participants' views on the meaning of (mining) production and its relationship with the government. Specifically, they shared a perspective that preferential treatment is given to groups that produce for the state, and those that do not are excluded. Don Miguel, 67, the former CORIDUP vice president and president, described a meeting CORIDUP had in La Paz in which they had a brief interaction with President Morales. Don Miguel denounced: "One time we directly asked the president to support us, and he told us, 'mining contributes to the state, it pay rents, you don't'...Can you believe he told us that? That means whoever contributes [economically] has rights, and we don't." Don Miguel explained this happened around 2009, during the time that many of the CORIDUP communities were still in full support of Morales, which was very shocking for him. Doña Jazmin, 50, from Kochi Piacala, Machacamarca was not part of the CORIDUP mobilizations, yet she shared a similar view:

Here not even the Mayor takes care of us. We are still poor, and it is us, campesinos... we have seen nothing from all that talk about improvements for us, sometimes I think we are worse than before...campesinos like myself 
would not expect anything from the government because we knew it was discriminatory towards us. With Morales, however, people had higher hopes, yet the disillusionment was bigger since we still feel discriminated against by our very own.

Doña Elena, 68, from the Sorachico Ayllu was even more explicit in her perspective on class discrimination:

Nowadays it seems that there is justice only for the capitalists, and for the poor there is none. The capitalists have cars, many houses, but for us, los campesinos and the poor, for any activity we do we have to pay taxes; for every small trade I made, I have to pay taxes. Even when I go the market and I sell my [homemade] juices and make bs.15 (\$US. 2) per day I still have to pay a sale's tax to the government.

The state officials and CEPA representatives and the members of the two collectives that participated in this study also shared a parallel perspective. Don Rodolfo, 57, for example, who is the water systems supervisor for the Machacamarca municipality, expressed a comparable view to Don Miguel's: “Comparing the government support between agriculture and mining, obviously the one that produces more receives more support, so what I see is that the mining sector receives more." Sabrina, 37, a member of the Wasi Pacha collective, was unequivocal and explicit about how and why this class discrimination operates:

Now we have a different type of discrimination and it is about economics. There is a strong state support for mining, so some communities have 
organized against it [mining contamination], but they have no support, and they feel discriminated against because of their social standing as campesinos $y$ campesinas and little economic power against a majority. I mean the ones directly affected by mining contamination are the minority, and the ones contaminating are a majority.

\section{3. Divide and conquer}

There seems to be also a purposeful strategy by the MAS government to create and continue tensions within and between groups: "The MAS is applying word by word the Machiavellian law of divide and conquer. Evo has applied this rule to organizations and communities and he has achieved this goal," claimed Mario, 33, from the Wasi Pacha collective. Mario was describing what seems to be a tactic by the MAS government aiming at weakening dissent, such as the creation of parallel indigenous organizations that are in support of Morales. CONAMAQ (The National Council of Ayllus and Markas of Quollasuyu) is a confederation of indigenous governing bodies from the Bolivian Highlands representing sixteen Suyus. CONAMAQ was created in 1997 with the goal of promoting indigenous self-governance in relation to collective rights and natural resources, and it used to be one of Morales' closest allies (Fabricant, 2012; Peralta, 2014). However, its leadership became openly critical of Morales' approach to the TIPNIS conflict and it distanced itself from any affiliation with the MAS. In 2014 many pro-government leaders, with support of the government and the police, took the CONAMAQ office by force and created a parallel CONAMAQ which is openly supportive of Morales. This resulted in two CONAMAQs existing in parallel (a 
strategy known as parallelism), one in favor of and another against Morales (Peralta, 2014).

The MAS uses covert tactics of divide and conquer by manipulating dichotomies along ethnic, class, party affiliation, and within and between geographical populations, among many other divisions (Bebbington, 2009; Webber, 2015; Martson, 2013; Fabricant \& Postero, 2014, 2015; Peralta, 2014). Fabricant and Postero, for example, describe how during the TIPNIS conflict in 2011 the MAS government and regional elites pitted indigenous communities of the lowlands (who were against the government's plan to construct a highway throughout their territories ) against indigenous coca farmers (who are the political base of Morales and in support of this construction).

The table below shows some of these divisions, which include the ones mentioned before. These dichotomies are not mutually exclusive of each other and many times they overlap. ${ }^{66}$ These divisions often exist within communities and also between communities and municipalities as well as within and between Ayllus. ${ }^{67}$

\footnotetext{
${ }^{66}$ Disillusionment with Morales and his party, MAS, is not restricted to the social and environmental spheres. The very public corruption scandal involving a romantic relationship between Morales and Gabriela Zapata, a top executive of a Chinese-owned construction company that received large government contracts, is a notable example (Rogatyuk, 2016). There is also the ongoing and worsening nepotism based on party affiliation, where one has to belong to MAS in order to obtain a government-related job (Hollender, 2016). Skilled professionals continue working as taxi drivers or in the informal economy, while unskilled and inexperienced professionals who are affiliated with MAS obtain lofty governmental positions.

${ }^{67}$ There are also the direct and physical confrontations that communities and their leaders experienced. In 2013 there was a confrontation with the miners: "We, CORIDUP, were talking with [the mining company] Inti Raymi and by the end they came, like 200 miners came, they told us we were traitors, that we were an NGO. There was like 15 of us, and they pushed us and almost punched Don Miguel in the face" (Doña Elena, 68, Sorachico Ayllu, El Choro). As Don Luis from CEPA points out, these confrontations between the mining companies and the communities are a direct result of a government's strategy of absence: "What the government has done these years is to confront cooperatives with the communities directly by being absent from any audit or control process, when in reality it is the government the one in charge to protect the rights of communities."
} 
Table 7. Divide and conquer strategies of the MAS government

\begin{tabular}{|c|c|}
\hline THEME & ILUSTRATIVE QUOTE \\
\hline $\begin{array}{c}\text { Miners } \\
\text { vs. } \\
\text { Campesinxs }\end{array}$ & $\begin{array}{l}\text { "Now there are peasant organizations vs. miner organizations. The miners say } \\
\text { 'we have the right to work for our daily bread' and the peasants reply 'and how } \\
\text { about us? Like you go inside the mine, we go inside our fields to work to get the } \\
\text { same bread for our families' so there is a deep conflict between them." (Don } \\
\text { Lucio, 55, CEPA) }\end{array}$ \\
\hline $\begin{array}{l}\text { Machacamarca } \\
\text { vs. } \\
\text { Poopó } \\
\text { Inter Municipality } \\
\text { divisions } \\
\end{array}$ & $\begin{array}{l}\text { "We worked a long time with CORIDUP but because we are eight Ayllus, one } \\
\text { part from Machacamarca supported CORIDUP, and they have obtained all the } \\
\text { benefits that should have been for everyone. I heard that Machacamarca is } \\
\text { receiving all the projects while there is nothing for Poopó." (Doña Victoria, } 49 \\
\text { Quellia, Poopó) }\end{array}$ \\
\hline $\begin{array}{l}\text { Government } \\
\quad \text { vs. } \\
\text { Indigenous } \\
\text { authorities }\end{array}$ & $\begin{array}{l}\text { "With the Mayor of Poopo who is MASista [from the MAS] we have no } \\
\text { relationship, she gets mad and does not want to support us. We as indigenous } \\
\text { authorities ask her for support and she says: 'There is no money, I have no time,' } \\
\text { and she mistreated us that way, but my Mallku challenged her, he said 'you are } \\
\text { the Major but we are the social control, we are allowed to watch over you' and } \\
\text { that's how we asked for her to be revoked. So we have no relationship with them } \\
\text { and therefore we have lost a lot of projects, like the PCP." (Doña Amalia,35, } \\
\text { Quellia, Poopó) }\end{array}$ \\
\hline $\begin{array}{l}\text { (Between) } \\
\text { Contaminated } \\
\text { vs. } \\
\text { Non-contaminated } \\
\text { Communities }\end{array}$ & $\begin{array}{l}\text { "The communities and people not affected [by mining contamination] are } \\
\text { receiving a lot of help. I heard that in Peñas, they have water, houses, everything, } \\
\text { but us, we get nothing and that's bad because the government support only those } \\
\text { who produce. Since we produce nothing, we receive nothing." (Doña Carmen, } \\
78 \text {, Kochi Piacala, Machacamarca) }\end{array}$ \\
\hline $\begin{array}{c}\text { Within } \\
\text { Communities }\end{array}$ & $\begin{array}{l}\text { Gisela: And does mining produce jobs for your community? } \\
\text { Doña Patricia: Yes, but not a lot. In my Ayllu, the most affected of us, we try to } \\
\text { take care of the land. Sometimes in the meetings we agree that we cannot go } \\
\text { work for the cooperatives, but then there are others that go and become miners } \\
\text { and we feel hurt because then we fight between us and in the meetings we can't } \\
\text { take any decision. The Tata Mallku also suffers because some people think he } \\
\text { should say no more mining, but he can't. Like a father, he has to look for the } \\
\text { wellbeing of everyone in the community. }\end{array}$ \\
\hline $\begin{array}{l}\text { Community } \\
\text { vs. } \\
\text { community } \\
\text { Within the same } \\
\text { ayllu } \\
\end{array}$ & $\begin{array}{l}\text { "Some are miners, so our Ayllu is now divided, we had two Mallkus, and they } \\
\text { fought against each other, one for the contaminated communities and one for the } \\
\text { non contaminated. And when we complained about contamination, they got mad, } \\
\text { very mad." (Doña Amalia, 35, Quellia, Poopó) }\end{array}$ \\
\hline $\begin{array}{l}\text { Rich vs } \\
\text { Poor }\end{array}$ & $\begin{array}{l}\text { "The cooperatives have a lot of freedoms just because they are supposed to fulfill } \\
\text { a social end. Supposedly poor people work in the cooperatives, but this is not } \\
\text { true. It is rich people hiring other poor workers, they hire peones." (Holga, 32, } \\
\text { Las Ramonas collective) }\end{array}$ \\
\hline
\end{tabular}




\begin{tabular}{cl}
\hline & $\begin{array}{l}\text { Don Roberto: There was an attempt to open a mining cooperative here [in } \\
\text { Machacamarca] and nobody knew about it, but I saw a document signed by four } \\
\text { Indigenous leaders } \\
\text { vs }\end{array}$ \\
local community leaders giving the company authorization to work. \\
Gisela: Was this part of a previous consent? \\
Roberto: No, there was no council, no cabildo for people to participate. So these \\
four leaders accepted this mining project but without consent. So this creates a lot \\
of mistrust from communities to their leaders. \\
"We have a deep rooted issue and that's that our Ayllu is going countercurrent \\
wgro-farming \\
ws \\
with the province...the Poopó province is classified as a mining sector...and this \\
creates a lot of trouble and divisions within and between Ayllus, because within \\
the province there are mining Ayllus and there are agricultural ayllus and then the \\
municipality is an agro-mining municipality.. you get it? So when we ask for \\
projects and when we design our projects they [government officials] say we \\
can’t access them because the province is a mining sector." (Don Aurelio, 48, \\
Punaka, Poopo)
\end{tabular}

Table 7 shows quotes illustrating many of the divisions and conflicting interests within and between communities, municipalities and Ayllus. Many of these divisions existed before Morales and therefore these should not be attributed to his government exclusively. Some comunarixs in this study, for example, protested that their leaders did not care enough about their complaints because the leaders are often residentes who do not engage in subsistence agriculture: "Sometimes I wonder about our leader Don Manuel...he doesn't live here, he doesn't understand our needs, he is a teacher, he gets a salary and he is fine. That's why he doesn't make any demands, but when we receive any help, he is the first one in line," protested Doña Tamara, 38, a comunarix from Alantañita. Doña Raquel is the person in charge of CEPA's program to support local communities affected by the drying up of Lake Poopó, and has worked in Oruro for over 20 years. She explained to me that the class divisions and competing interests that Doña Tamara described result from the rural diaspora explained in Chapter Four, where those who leave, although still poor, might gain some economic advantages over those who stay, and men in particular, who are more likely to leave and find full time and waged 
jobs, "tend to be leaders just in paper." At the same time, however, Doña Raquel explained:

There has been an increasing division between community leaders and their bases since 13 years ago...Mining companies and the government have manipulated the election of local leaders, supporting those with no experience to make sure they contain community frustrations...these new political and administrative changes within the $\mathrm{CPE}$ have also changed the role of indigenous authorities...instead of strengthening social relationships, these new roles are eroding them because they are now forced. There was a case in Poopó where an ex-miner was forcibly elected because [the mining company] Sinchi Wayra got involved under the excuse they were creating a project for the community.

Furthermore, many participants brought up the dichotomy agro-ganadero vs agro-minero [agro from agriculture and ganadero from livestock, and minero for miner] to show how it halts projects and how this dichotomy has been exacerbated under President Morales in the last 15 years [a timeframe that aligns with the increased demand for primary commodities from China and Morales' election]. When a region or municipality is given the agro-mining classification, agro-minera, this means that both of these activities dominate the economic life of the region. This classification also affects the type of projects that communities are able to receive. Eighty-five percent of mining royalties are distributed throughout all Bolivian governances (nine departments) and 15 percent of these royalties go directly to the producing municipalities (Fides, 2018). So when a 
municipality is classified as mining or agro-mining, it receives these royalties and communities within this municipality are expected to be uncritical and supportive of mining activities, since they receive the economic benefits from it. Projects for agricultural sectors might also exclude these communities since they are considered agromining regions. Except for El Choro, all three municipalities within CORIDUP have the agro-mining designation. Yet participants argue that the agro-mining label, agro-minero, is misleading: "It should be minero-agro [mining-agro] or just mining to reflect the priorities of the municipalities and the government," said Doña Victoria, 49, from Poopó. Besides, as mentioned by Don Aurelio, 48, Tata Major for the Puñaka Ayllu, the agro-mining duality is also a main issue within Ayllus, which have their own economic denominations that do not always overlap with the municipality. The Ayllu he belongs to, San Agustin the Puñaka, self-identifies as agro-ganadero [agriculture-livestock]; however, the municipality it belongs to, Poopó, is considered a mining sector. This translates into a conflict between Ayllus and their respective municipalities about how to spend the royalties received as well as subjugating agricultural interests and projects. Moreover, Ayllus, which are formed by many communities, are supposed to work as a cohesive unit; however, an Ayllu's communities might belong to different municipalities. This affects the Ayllus' organizational capacity and response to mining contamination. Such a situation has led to conflicts within and between Ayllus.

There is also an antagonism between authorities representing the government (the Mayor and governor) for example and those representing indigenous communities (Tata Mallkus, Mama T'allas). Participants explained that in theory, both public and 
indigenous authorities have the same political capacity and decision-making power over communities' matters. In reality, however, participants felt that this is just rhetoric and pure symbolism: "Public authorities get paid for their positions, while indigenous authorities do not," said Doña Laura, 52, from the Caravi community. Webber (2017) argues that often indigenous leaders are co-opted into the state apparatus where their position as low-level state managers conflicts with grassroots demands against neoextractivism and the state. This intertwines with corruption claims and scandals alleged against MAS and mining companies that use unabashed buyout strategies. Don Lucio, 55, from CEPA gave an example of such strategy:

Don Lucio: The company has a strategy of corrupting the leaders that is terrible. Gisela: What is that strategy all about? Don Lucio: To make money flow to the local leaders. In CORIDUP there was this guy... and he received money from the mining company to stay quiet and he not only betrayed us but he also tried to divide us, and for a while, he succeeded. We were confronting each other. He spoke behind our backs, trying to make comunarios believed we were receiving money, but we didn't. Gisela: And what about the government, what did they do? Don Lucio: The government pretended they did not know, they played neutral, but it was not neutral, they were supporting Huanuni [mine].

There are also antagonisms that have emerged as a direct result of Morales' unconditional support to some groups such as the miners, "who now feel empowered to do and demand as they please... it is as if the miners were saying, 'you can stand upside down, but we 
have the support of the state so we will do whatever we want'. They [miners] Don't say that but they behave like that," argued Sabrina, 38, from Wasi Pacha. As participants argued before, this is because of the state's economic interests on miners as rentproducers for it. There are also political motives. The miners, like coca farmers in the lowlands, as a sector that has benefitted significantly under Morales (Webber, 2017), are also part of his political base, and not just any base. As political actors, Bolivian miners were among the most radical workers in Bolivia and Latin America in the 1950s (Gareca, 2006). Although severely affected by the neoliberal policies of the 1980 s, miners have substantial experience organizing successful protests and political unrest. As Doña Victoria, 49, from Quellia, Poopó explained, "when miners protest, the streets tremble," referring to their powerful organizing capacity (also literally as they often use dynamite during rallies). It is in MAS' interests, therefore, to keep its base unoffended. ${ }^{68}$

In Table 7, Don Lucio, 55, from CEPA, also points to the ongoing competition between miners and peasants in relation to the right to work, which connects to survival struggles. As emphasized elsewhere, participants in this study do not demand that mining companies be closed down precisely because they understand that miners also need to survive. Participants are demanding an equal understanding and respect for their right to survive, which for them has yet to happen.

The boom in demand for primary commodities from China has created in Bolivia a bonanza based on higher rents and taxes. Although similar bonanzas happened in the past, it is only under Morales that this bonanza was largely invested in progressive

\footnotetext{
${ }^{68}$ In 2016, two miners died during confrontations with police and the deputy interior minister was kidnapped and killed by striking miners who were demanding more mining concessions, the ability to work and negotiate with private companies, and greater union representation (The Guardian, 2016).
} 
policies that benefited many sectors of the Bolivian poor. At the same time, such a high influx of revenue has also amplified existing class differences. In connection to other dichotomies, some community leaders have benefitted from corrupt strategies of cooptation at the expense of their communities. There is also an emerging class of indigenous petit bourgeoisie, such as coca growers, traders and a small elite of miners, who have benefited as well (Webber, 2017). As described in Table 7 in the quote by Holga, 32, from collective, some cooperative miners became rich, while others, such as peones, remain poor. What seems, however, to be a strong and new division that has emerged as a consequence of Morales's divide and conquer strategy is that of party affiliation.

\subsection{1. "Si eres del MAS te va bien" [if you are from MAS you will do well]}

When I was in Bolivia, friends, family and strangers whom I engaged in random conversations (particularly street vendors and people at the local food market where they sit next to each other to eat on big tables) complained that nowadays, one has to be a MAS party member in order to move up on the social ladder: "Si eres del MAS te va bien, y si eres del MENOS te va mal-jajaja" [if you are a member of MAS you will do good, and if you are from MENOS, you will fare poorly (laughter)] (comidera, food street vendor, La Paz, Bolivia). ${ }^{69}$ Moreover, people complained that anyone who criticizes the Morales government is accused of being from the political right, or a puppet for imperialism. I initially thought these people were exaggerating. Yes, I was aware that a few years ago there were news reports that Morales had threatened to expel four non-

\footnotetext{
${ }^{69}$ In Spanish, MAS means more, and MENOS means less. Here the street vendor is making a joke to highlight the division based on party affiliation.
} 
profit organizations due to their alleged connections with American institutions, ostensibly for contributing to an imperialist agenda to destabilize his administration (Achtenber \& Currents, 2015). ${ }^{70}$ However, I was surprised when the participants of this study, indigenous campesinxs from rural communities in the Altiplano, a region known for its support of Morales and part of his original political base in 2005, had similar complaints: "There are some campesinos who have received houses and a lot of things, maybe because they are MASistas [belonging to the MAS party], but I have received nothing, I only received a cake given to older people for Christmas...that's how Evo tricks us," mentioned Doña Carmen, 78, from Kochi Piacala, Machacamarca. Participants in the Poopó municipality also shared similar complaints. Doña Karina, 53, was a Mama T'alla of Puñaka, Poopó and like many other people from there, she had to migrate to Argentina and Spain for many years due to the lack of economic activities available to survive. We discussed this issue:

Gisela: I wanted to ask your opinion about the MAS: Are things better, worse, the same? What do you think?

Doña Karina: Things have not changed...he [Evo] says there is no discrimination but I see even more discrimination.

Gisela: Ahh...How so, what do you mean?

Doña Karina: There is more discrimination to the indigenous authorities. If you are a MAS politician, then you have respect and [you] can do things for your community, if not, then you have none and then the doors are closed...so

\footnotetext{
${ }^{70}$ Although none of the four mentioned non-profit organizations have been expelled yet, the IBIS, a Danish non-profit, was expelled in 2013 due to allegations of political interference. 
now the discrimination is even worse, and anything becomes a reason to send you to jail.

Members of CEPA that I interviewed for this study shared a similar view:

The MAS claims to be a party of social movements, and who are these? CONAMAQ (The National Council of Ayllus and Markas of Quollasuyu), Las Bartolinas ${ }^{71}$, etc., so if you are part of these organizations, you receive projects, and that's bad because community support and development is now politicized, and if you are against the MAS, then the doors are closed (Don Luis, 43, CEPA).

Even participants who still support Morales and were outspoken about the advances in ethnic inclusion, recognized that such privileges based on party affiliation do exist. Tania, 28, from the Wasi Pacha collective, was very eloquent and affirmative about her support for Morales based on her own experience with discrimination as an indigenous woman. She also had a concrete understanding about the hegemonic tendencies of capitalism:

If you realize it, Bolivia is among the most corrupted countries in Latin America, and all our history is a history of colonialism and capitalism, so to bring a new philosophy, a new way of living different to that of capitalism in just one country and try to transform the country in 10 years is not an easy task, no easy at all.

Yet Tania also recognized that there are benefits and exclusions based on party affiliation:

${ }^{71}$ Las Bartolinas refers to the National Confederation of Campesino, Indigenous, and Native Women of Bolivia. 
In Oruro, since many years ago, ever since the formation of the MAS, communities have offered a strong support to the government, as you can see in the Jacha Carangas Suyu [the highest indigenous federation in the department of Oruro and its proximities] and that has many good things, but there is also an issue when your communities are not openly supportive of the MAS, they get ignored, and this creates tensions among communities. Other participants like Doña Amalia, 35, from Poopó expressed their outrage for being called right wing just for being critical of the government's approach to mining contamination. ${ }^{72}$ Doña Amalia is originally from the well-known Qaqachaca Ayllu in Oruro and she is one of the youngest Mama T'allas I interviewed. ${ }^{73}$ She captured these contradictions in the following lines:

When Lake Poopó was drying up, many MAS senators, deputies, many came [to see it] and we told them 'look, nobody has done anything about the lake and no one fulfilled the promises [of decree 0335]'. And they replied 'ahh, eres de la derecha [you are from the right], you are not part of the process of change, you are disrespecting our president Evo,' and just like that, they

\footnotetext{
${ }^{72}$ Many participants also shared that such labels of right-wing are an oxymoron since it is well known that the MAS has been infiltrated by many politiqueros [politicians] from all political factions, including those from previous right-wing parties. "During right-wing regimes political parties were garbage containers for any cheap politician from right, center, left, anything, and Evo is doing the same... what I mean is that they are opportunists" (Lucio, 55, CEPA).

${ }^{73}$ Qaqachaca is known for its strong socio-political organization as well as its fiery defense of its cultural traditions and territories. As Doña Amalia shared with me, because in Qaqachaca there is no contamination, there is little migration and therefore kinship and social relationships are strong and the soils very fertile. Comunarixs have been able to grow all kinds of foods and have been able to obtain many projects, particularly for women's empowerment, such as projects to support and develop traditional weaving. Moreover, Qaqachaca is very wary of outsiders and outside influences and very protective of its borders, which has led in previous years to bloody conflicts with its neighbors, the Laymis and Jucumanis Ayllus and the state. In 2018, the Qaqachacas and Laymis ambushed and captured nine FELCN (Special Forces Against Drug Trafficking) who were patrolling the region without previous authorization of the local and indigenous leadership. There were, however, some rumors that some Qaqachacha's comunarixs were involved in drug trafficking ("Desplazan personal", 2018).
} 
discriminated against us... they were indigenous and you would think because

of that they would take care of our lake, but they did nothing so we fought

against each other, we were discriminated by our own... then there was a

senator of pollera [indigenous skirts], she should have placed her hands in her

heart, but no, she said to me 'you are from the right' but I am also of pollera,

so to be told that I am from the right was very insulting, I was very upset.

Doña Amalia did not know what "being from the right' meant since she asked me about

the meaning of this phrase. However, she understood that it had negative connotations

and that this labeling represented being in opposition to Morales, to a point of being his

enemy, and she is correct in her intuition. As mentioned before, there is a general climate

where the MAS government has divided the Bolivian population into two poles, those

who support Morales and those who do not. Those who do not, although they represent

diverse groups with varying political stands and criticisms of Morales, are lumped into

one umbrella group labeled the opposition. The MAS government has strengthened the

perception that the opposition is synonymous with racists, right-wingers and

imperialists. ${ }^{74}$ Before the TIPNIS conflict in 2011, such allegations were largely true.

\footnotetext{
${ }^{74}$ The result of the 2016 February 21 referendum (21F) has become the epicenter of Bolivians' disillusion and has led to massive protests in recent years. In 2016, a constitutional referendum was held to remove presidential term limits. This would have allowed Morales to run again for a fourth consecutive time in the upcoming 2019 elections. Morales lost the referendum by a small but definitive margin (51\% against, $49 \%$ in favor). Shockingly, in 2017, as part of a penal code overhaul, the Constitutional Court removed the stipulation on term limits. Morales stated, "I don't want to [run again], but I cannot let the people down." This response sparked ongoing rallies and protests which have polarized Bolivia into two camps: Morales supporters and Morales critics. The slim difference in 21F shows there are thousands of Bolivians who still support Morales and are ready to confront anyone opposed to his government. This segment of the population consists mostly, although not exclusively, of constituents that benefited the most under Morales: coca farmers (particularly from the Chapare region), cooperative miners, and commercial traders from the indigenous city of El Alto. Those opposed to a fourth Morales presidency, a slight majority of Bolivians, are becoming angrier and suspicious about his aspirations to remain in power for another term, or perhaps indefinitely. This segment consists of a wide array of groups and peoples, such as indigenous communities from the low and highlands, Alteños, or people from El Alto (the city that became a key point of action
} 
Morales' first presidential term (2006-2010) witnessed a strong backslash by the Bolivian lowland elites, who were mostly if not all wealthy European-descendant agrobusinessmen who did not hide their racist disdain for an "Indian" president. Moreover, for them, the election of Morales represented a dangerous transformation of the state into the other who promised radical land redistribution and ethnic inclusion. Through an interdepartmental coalition called la Media Luna (half moon) that included five out of nine departments (Tarija, Beni, Pando, Sucre, with Santa Cruz as the leader of this coalition), these lowland elites created a mass movement demanding regional autonomy. Among the Media Luna's cunning antigovernment tactics was the crafting of a regional identity for popular mobilization that turned extremely racist and violent (The Democracy Center, 2008). The Media Luna failed, and Morales is now in his third presidential term. Nevertheless, Morales has used these previous events to frame any criticism to his government as emanating from la Media Luna.

Government officials interviewed in this study also recognized the contradictions of the Morales government in respect to the mining sector: "Mining activities have always existed and will continue to exist. Every government including this, has a development program where mining is always central because it generates rents for the country, so it will not stop," argued Don Alvaro, 60, the lead of the rural contingency unit in the Ministry of Rural Development and Territories, MDRyT. Don Alvaro also pointed to the lax implementation of laws regarding the mining sector: "the laws supposedly prevent mining waste to go straight to the rivers, but there is not a rigid system in place to enforce them, so what do we do?" As part of such 
contradictions, Don Alex, 52, the water systems coordinator for the Huanuni Municipality, pointed to job generation within mining: "Of course it is a big contradiction, but then what do we do? If we or CORIDUP denounce the high levels of contamination, they come and close the Huanuni mine, and then what do we do with 3,000 unemployed miners?"

For these participants, the issue is not the government dodging its role as an enforcing entity of environmental and indigenous rights. The main issue is that the central government does not have a ministry or government institution assigned to tackle the special needs of contaminated communities. Don Alvaro also pointed to the contradictions and divisions within municipalities: "The Ministry of Mining should take care of this and also the municipalities, but the people within the municipalities are also miners because it is a more profitable activity than agriculture, and I Don't know if that is a contradiction or an opportunity." I asked Don Alvaro about the Ministry he works for, the Ministry of Rural Development and Territories, and whether it should or should not have responsibility for this issue. He declared, "some of these issues overlap with our unit's scope, yes, but we barely have any money assigned to these or any projects, and it is also not our responsibility... that's why the solution has to come from the upper government, they have to assign a budget for these problems." Don Alex, 53, questioned the role of communities themselves in this issue, specifically as related to SD 0335 :

If I go to a tailor and he says my suit is going to be ready in 30 days and then it is not, then I make a scandal. The same should be true for 
CORIDUP, they should be stronger and tell the state that they promised the tailing dam by 2011 , force them [the state] to fulfill its promises.

These participants also recognized that preferences do exist based on party affiliation. For them, the lack of professionals with technical knowledge and expertise in public positions reflect party-based preferences. Don Rodolfo, 55, the water monitor supervisor from the Machacamarca municipality, explained that "this government, like all governments before, has done the same thing... they brought someone from Cochabamba, a MASista that never worked in el Altiplano, and he wanted alfalfa to grow all year long, that's crazy! So sometimes they bring technicians that do not know anything."

Curiously, discourses about climate change as the cause of environmental issues emerged only in conversations with government officials. Other participants mentioned being aware of delays in the rainy season or extreme weather conditions. Some of them expressed that "el tiempo esta cansado" [the weather is tired]. On the other hand, government officials interviewed in this study expressed that many of the main socio-environmental issues that Bolivia faces, including those of mining contamination, are related to climate change:

Don Alvaro: We are subjected to climate change, and that comes from industrialized countries. We have more droughts, frost fields, hailstorms, and flooding and that's a big issue for these communities. Before El Niño would occur every four years, now with La Niña it is every year.

Gisela: How about mining? 
Don Alvaro: Mining is married to production, to income and rents generation so it is not going to stop. But unlike him [Evo], I do consider mining a major issue. ${ }^{75}$

\section{4. Bureaucratization of life}

Amidst all the divisions, contradictions, and hardships, as well as the material and economic constraints that these communities have to face, they are still willing to keep organizing for a common cause. In Chapter Six, I will explain in detail what these organizing efforts require. Nonetheless, when communities are able to overcome the divisions mentioned, they then face the increasing bureaucratization of life and the bureaucratization of organizing efforts that has become common under the MAS government. Below I explain some of the causes of such bureaucratization and how it affects the participants and communities in this study. I will describe some aspects of the New Bolivian Constitution (CPE) in detail to show how the Bolivian state has increased bureaucratization in order to halt dissent and protests. Moreover, I will describe the discussions and events around an important meeting that CORIDUP had in La Paz, Bolivia in 2017 with high ranking government officials. I will illustrate what such increased bureaucratization of social movements mean for grassroots organizations such as CORIDUP and for indigenous peasant communities.

\footnotetext{
${ }^{75}$ It is telling that these government officials seem to use climate change as an excuse to ignore mining effects. In other words, they use the discourse of how global issues have greater effects than local ones. President Morales uses a similar discourse about capitalism, where he argues that Bolivia cannot change its mode of production unless there is a global systemic and political change. Critics argue that President Morales uses such discourse to condone how local projects under his presidency continue capital accumulation .
} 


\subsubsection{Decentralization and autonomy?}

The decentralization of the central government, where more autonomy and power are given to local and regional governments as well as to indigenous autonomous regions, is one of the many progressive clauses of the New Bolivian Constitution (CPE), created in 2009:

Second chapter, Departmental autonomy: Article 277 grants regional autonomy to the departments, which are conformed by departmental assemblies capable of having legal, auditing and executive powers. The maximum authority at the departmental level is the governor.

Forth chapter, Municipal autonomy: Article 283 states that municipalities are autonomous governments, constituted by a municipal council capable of having legal, auditing and executive powers. The maximum authority at the municipal level is the mayor.

Seventh chapter, Indigenous-originary peasant autonomy: Article 289 states that indigenous autonomy consists of self-governance as an exercise of free determination of indigenous-originary and peasant nations. Indigenous autonomous regions are based in ancestral territories that are currently occupied by these nations and communities. The governance of these indigenous autonomies should be executed based on their norms and ways of organization (CPE, 2009).

The goal of decentralization is "to transform the state into an institutional organization that responds to the needs of all Bolivians, to distribute power and to bring the state closer to its citizens so people are able to have their own government to address their problems" (Ministerio de Autonomia, 2009) [emphasis added]. Similar to Weber's (1905) definition of bureaucracy, it seems that the CPE also assumes that decentralization and bureaucracy are the most efficient means to manage organizations based on the painstaking division of labor and responsibility. But for indigenous peasant communities and grassroots organizations like CORIDUP, government decentralization translates into layers upon layers of bureaucratic processes at the municipal, departmental, and national 
levels, as well as layers upon layers of having to deal with different decision makers. Bolivians experience this increased bureaucratization in their everyday lives, such as paying bills, as well as in the socio-political sphere, when community leaders demand to meet with government officials to address community issues. As Doña Mariana, 58, from Alantañita, Machacamarca explained, "to have an appointment with a government authority like the Mayor or Governor, or to have a document signed and approved [by a government institution], you must walk from one office to the next one, from one institution to the next one, waiting in line each time, and so on.” The community leaders I interviewed framed such bureaucratization as "mucho caminar, nos cansa mucho" [too much walking, we are tired].

Public institutions such as the Ministry of Environment and Water (MMAyA) where CORIDUP places some of their demands are usually understaffed and underequipped, with unclear delimitations of what falls under their responsibilities, creating disorganized and sometimes unnecessary processes. There is also a lack of coordination between communities and the local autonomous authorities (municipalities) that are supposed to guide them with project proposals, submissions and management, but often do not. Doña Mariana, 58, from Alantañita, Machacamarca illustrated this situation: "One time we presented a project, we walked a lot to get it approved, and right at the end, the Mayor told us it was not applicable because this is an agro-mining municipality. They should say those things right at the start, so we do not waste our time."

Moreover, the formal recognition of indigenous authorities under the new constitution has translated into two scenarios: a) another layer of authorities that 
communities have to deal with since this formality requires signatures of indigenous authorities; b) the inclusive policies of indigenous representation mean that many indigenous authorities have some form of dual roles as indigenous and [unofficially] government representatives. In other words, many indigenous leaders have been co-opted into the state apparatus, which leads to ambiguous and sometimes conflicting interests between these two positions, since now their own material life depends on the continuation of the status quo (Webber, 2016, 2017). As participants explained, although the constitution establishes that indigenous authorities have a greater political power than government ones, and therefore deserve equal respect, in reality this is not the case: "They say our Tata Mallku has the same authority, but it is not true, the Mayor has always been very rude, even with our Mallku, as if he had no authority," complained Doña Victoria, 49, from Quellia, Poopó.

For the indigenous campesinx women in this study, this bureaucratization represented even more difficulties for their organizing efforts. With one exception, all of the women I interviewed were mothers or grandmothers, which means that their children usually accompany them in these processes, or that women must leave their children at home. For indigenous campesinx women who still depend exclusively on agriculture and livestock for their survival, they also have to consider who will take care of their animals while they are in the city trying to meet with local authorities or trying to get signatures. I left the house of Doña Paula in Kochi Piacala the weekend right before local elections. For Doña Paula, local elections mean that she has to walk 1.5 hours one way to go to the place where she is registered to vote, and her husband, Don Francisco, 85, has to ride his 
bike for 45 minutes into the opposite direction to the town where he is registered to vote. Doña Paula was worried about her animals: "It does not matter what you do, they still have to eat and drink every day," she told me. Someone had to take care of her animals, and that meant paying that person bs. 100 (\$US. 15 per day). Voting is mandatory in Bolivia and many public-led institutions, such as banks, the electric company, etc. require a voting card (proof that a person voted) for three months after the election day to offer their services. I was sure there was some leniency for older adults, as Doña Paula is 72 and Don Francisco is 85 . Therefore, I called different places to confirm this assumption. Since we were in the countryside, the phone signal was very bad and that itself became an issue. I called the town hall in both cities, but nobody I spoke with had any useful information and they told me this issue was not under their responsibility. Someone recommended calling the police to see if they could assist with transportation. The police stated it was not under their responsibilities and they suggested contacting the public hospital or clinic as the ambulance of the Machacamarca town helps with transportation. However, the ambulance was not working. I was finally able to reach my cousin who is a lawyer and he found out that older adults (above 65) are not required to vote. Doña Paula and her husband still decided to go because if this information was inaccurate, it would mean tremendous barriers for them. For one thing, Doña Paula borrowed \$us 1,000 from Banco Union [Union Bank] to buy more animals so she could increase her production. This means that each month she has to travel to the city of Oruro to make payments, and not having a voting card would mean Doña Paula would lose her credit and pay a hefty daily fee for late payments. 
Increased bureaucratization obscures who is in charge of what, and it creates unnecessary processes which lead to people wasting time by making phone calls, or worse, walking from one place to another, meeting a bureaucrat and then another, in order to find the information or service they are looking for. This is amplified in a context where people often lack resources, and where spending half of a dollar on a phone call becomes a significant economic barrier. Rather than being efficient, bureaucracy controls and directs "man's existence... he is unable to escape from the regulation and manipulation [where] he no longer controls his own destiny (Jacoby, 1969, p. 1).

\subsubsection{Bureaucratization and grassroots organizations}

My fieldwork included participant observations with CORIDUP. I attended five of their meetings, plus a trip to Bolivia's capital, La Paz, in December 2017, where CORIDUP met with the Comptroller General of the State. The purpose of these meetings (CORIDUP and government) is to discuss the progress of environmental projects mandated under SD 0335. The two CORIDUP meetings prior to this trip involved discussions about the demands to be proposed for that meeting as well as a review of what had been accomplished. These two meetings were well attended, with 25-30 community leaders, both men and women. The participants' main complaints were that throughout the last few years, CORIDUP has had many of these types of meetings with government officials that have led to no results. People complained about the layers and layers of bureaucrats that they had to deal with, not just as part of CORIDUP, but also as independent community leaders. A leader from Yuracaré, Poopó, who was in his mid 50s, shared the following: 
Hermanos y hermanas, we have an important meeting but I wonder if it is going be again a waste of our time. We need [government] people with the power to make decisions and not just the sandwiches [lower ranking officials that stand in between community and decision makers] because the authorities have been absent.

Participants described government technicians, (such as environmental engineers, agronomists, etc.) usually are the ones attending these meetings. Although they might have good intentions, are unable to offer any solutions or compromises to the CORIDUP'S demands in relation to SD0335. "The technicians are like sandwiches, they are between us and their bosses and the authorities always have excuses not to show up," complained Doña Elena, 68, from the Sorachico Ayllu. Technicians, as it was explained to me, always promise they will share people's concerns with their supervisors and also promise follow-up meetings. However, a follow-up meeting rarely happens, and if it does, it is because community leaders put in considerable effort to walk from one place to another demanding them. When follow-up meetings do happen, they become just another meeting with another technician, who might have a higher position and more authority, but still is not the person ultimately in charge of decisions. This results in an ongoing sequence of meetings leading to the complaints that organizing takes too much time and walking and leads to no results. The following is a detailed description of such meetings.

\subsection{3. "Nothing specific for us"}

The trip from Oruro to La Paz takes four hours by bus. Because many CORIDUP members who travelled with us came from rural communities, we decided to leave 
Oruro around 12:30 am. This allowed people to travel from their communities to Oruro during the day and allowed us to sleep in the bus and not to pay for a hotel (bs. 20, or \$US 3 per night). Although the trip expenses were covered by CEPA (bus tickets and food), for comunarixs, the bs .20 for a hotel is an extra expense that many cannot afford. Around 45-50 community indigenous leaders and comunarixs traveled to La Paz so they filled the entire bus. There was a slight majority of men, but women also had significant representation in numbers as well as leadership roles, which was clearly reflected in their clothing (indigenous leaders, both men and women, wore the traditional green and multicolor ponchos and mantas). Some of the women arranged snacks that they distributed to everyone in the bus. We arrived to La Paz around 6:00 am and because the meeting was at 9:00 am, some people passed the time by sleeping in the terminal while others went looking for food. I joined the group from the Poopó region that had perhaps the highest number of participants (around eight or nine of them). I did not know them and took the opportunity to start a conversation. It was a very cold morning and we ate quinoa with milk, which is sold by street vendors in almost every other corner. They were curious about my research and I was curious about their daily lives in Poopó. For most of the time however, we joked about the meeting while seating at Plaza Murillo where the government palace is located. Figure 15 (picture to the left) shows the Tata Mallkus and Mama T'allas that participated with CORIDUP in the meeting with government oficials in La Paz, Bolivia. The picture to the right is a community leader criticizing the lack of participation of high-ranking government officials.

Around 9:00 am we all regrouped outside the Comptroller General of the States' 
office and then we went inside. In this meeting there were around 13 government representatives from the General Directorate of Mining, Environment, Water, and Environmental Health as well as the Comptroller's manager. From the very beginning, CORIDUP leaders expressed their disappointment. "We appreciate that you [Comptrollers' Manager] have this goodwill to meet with us, but we want a meeting with higher level authorities. We were promised this meeting was going to be with the ministers, but none of them is present," disappointedly expressed Don Manuel, a community leader from the Machacamarca municipality.

As the president of CORIDUP explained to me later that day, the ministers of Mining, Environment and Water, and the minister of Rural Development and Territories were supposed to be present. However, to his frustration, this turned to be just another meeting with middle rank officials, or "the sandwiches" who do not have any decisionmaking power. From his side, the comptroller's manager also expressed his frustration. He explained that he did extend the invitation to this meeting to all related ministers as well as to the Mayors of the affected municipalities, including Oruro's governor, who is a central authority on this issue. Nevertheless, none of them came nor replied to his invitation. 

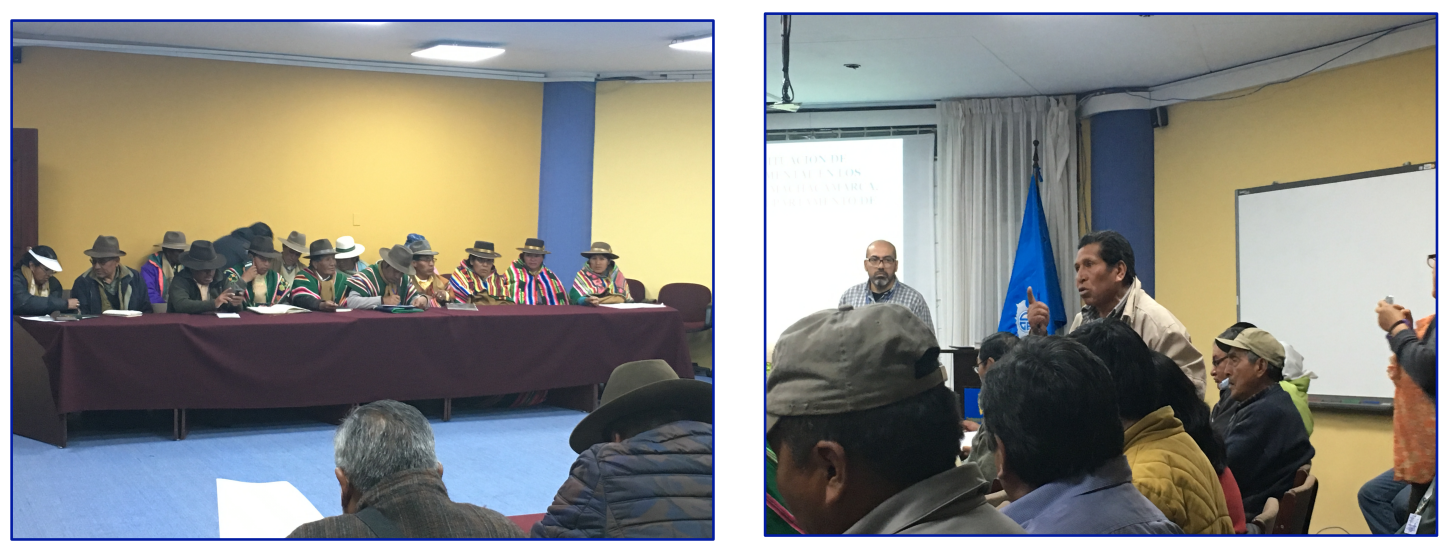

Figure 15. CORIDUP Meeting with state officials in La Paz, Bolivia. Photograph by the author. The meeting started with a brief description of SD 0335 and what had been

accomplished. The director of clean water from the Ministry of Environment and Water did a presentation about the MiAgua project, which builds irrigation systems to increase agricultural production. According to him, this project had benefited around 15,000 families. Before he could finish his presentation, Don Oscar, a community leader from the Huanuni municipality, interrupted exclaiming:

These programs are an insult to the CORIDUP communities since we cannot get any of the benefits that non-contaminated communities receive... How is one supposed to produce anything when the land and water are contaminated?...Son proyectos nacionales, no especificos a nuestras realidades [these are national projects, not specific to the realities of the our communities].

Don Felipe is a former and first CORIDUP president who now lives in the city of Cochabamba. Many participants referred to Don Felipe as the key person mobilizing the communities to rally and demand the approval of SD 0335. I only met Don Felipe once, during this meeting, and it was evident why he became such a key actor in these mobilizations. This 68-year-old campesinx dresses modestly with a black hat and grey 
wool vest common to older, indigenous men. He is small in size and very shy and humble in his appearance. Nevertheless, it was the soft yet convincing way with which he spoke truth to power that resonated across the room:

Our ways of being and living are disappearing, our animals, nuestras vaquitas y ovejitas [our cows and sheep] are dying, and on top of that you dare to ask us to meet again? We feel hurt that you repeat the same information, and we Don't know where all of this wickedness comes from. In Quellia we really suffer because of water. There are wells but they are contaminated, so how is it useful to have access to [contaminated] water? The Ayllus around the river are contaminated, we have truly become the tailing dam of the Huanuni mine...From 2009 till today nothing has been done; you are spoofing us, as if we were a joke... we feel displaced, we feel discriminated against that after eight years we are in the same position, and to us, these are shameful lies that you get away with just because we are poor and humble...there is no consciousness in you but there is complete discrimination toward us.

It was his understanding that the government discriminated against them based on their material conditions as peasants; the transparency and unpretentiousness of his attitude that created a silence in the room where everyone listened carefully to his words. Moreover, his speech was very impactful because he was speaking from a place of experience and truth, as well as addressing the complexity of contamination that involves access to clean water, displacement, bureaucracy and discrimination. After some seconds of silence and with some hesitation, the comptroller's manager 
addressed some of the issues Don Felipe raised. Then the presentations and discussions continued with the same logic: government officials presenting their projects and then CORIDUP members challenging their assumptions, or lies, as the participants called them.

At some point in the meeting, participants complained that the government officials assume they know nothing about the details of mining projects and therefore these presentations feel degrading to them. It was the indigenous campesinx women leaders who articulated the fact that although they might not have an academic or technical background, they do have the direct experience of living in contaminated areas with no access to clean water. CEPA and other NGOs have provided many trainings to them; therefore, many also know the technicalities related to heavy metals, the $\mathrm{pH}$ level of water, soil sedimentation, etc. Doña Karina, 63, from Puñaka, Poopó stood up during the meeting and explained this scenario to the government officials: "We [women] also know about this because we live it in our flesh. We have to look for water, we know by now the difference between clean and contaminated water and that the $\mathrm{pH}$ of our waters is really low, and we also know how our animals behave when they get sick from all of this." Women also highlighted that they have professionals within their communities that are able and capable of understanding these issues and challenge the information presented by government officials: "it is ok for them [government] to explain these [issues] but let's not let them put their fingers in our mouth because we also have people who understand these issues," explained a Mama T'alla from Poopó. ${ }^{76}$

\footnotetext{
${ }^{76}$ In general, for this study and for this region, it is men who have higher levels of formal education. I also found this pattern during a qualitative study I conducted in other indigenous communities in Guatemala,
} 
It was also the women within CORIDUP who pointed out the government's strategy of divide and conquer and they demanded a unity in action. In a meeting prior to the trip to La Paz, a male community leader from Poopó argued that his Ayllu was the most contaminated and therefore the meeting in La Paz should focus on demanding reparations to this Ayllu. However, Doña Maria, 35, a young Mama T'alla from Poopó as well, argued: "Hermanos hermanas, let's fight as a group; the people from Puñaka cannot say they are the most affected and try to receive more [benefits]." She argued that while such distinctions should be made during the internal CORIDUP meetings, the meeting in La Paz should be about all communities. She also highlighted that "they make us fight between brothers and sisters so we have to identify those authorities and take them out, we have to be united," in reference to the divide and conquer strategy that weakens their capacity to make demands.

Near the end of the meeting, the Comptroller's manager stated: "I understand your frustration, and believe me that I am on your side. I can't promise, but I will make sure that next time the pertinent authorities are present." The meeting therefore resulted in a commitment to have another meeting with higher authorities. This is the subsequent meeting in Oruro that I described in the previous section which, unsurprisingly, did not include any high government authorities either.

There was a short debriefing right after eating lunch, and CORIDUP members concluded that this bureaucratization is another strategy of the Morales government to demoralize and exhaust their efforts. "Ya estamos cansados" [we are already tired] was a phrase that participants commonly used to describe their frustrations. On our way back to 
Oruro in the bus, I asked some participants what being tired meant to them. On one hand, some participants explained being tired as a position ready to give up, tired of trying. On the other hand, some expressed being tired as being ready to take harsher actions.

At the debrief meeting two weeks later, one thing that emerged was a critical perspective about CORIDUP's leadership. Many community leaders demanded and seemed ready to take harsher actions, but the current CORIDUP leaders were not. "CORIDUP is acting too soft, the government gives you [CORIDUP leader] a report, a paper, and you leave happy with that," decried a Tata Mallku. I recalled that at a meeting for the Kochi Piacala community, a local member had also complained about CORIDUP inaction, and that no one answers the telephone: "They [CORIDUP leaders] are our representatives and they have to be available to us, asi que tendremos que chicotear si siguen asi [so we might have to whip them if you continue like this]" (whipping is part of the indigenous justice mechanisms used sometimes as punishment).

During that debriefing meeting two weeks after the trip to La Paz, Don Lucho from Kochi Piacala made a call to action:

We have to think how we are going to demonstrate our power and strength because the authorities are dismissive, they want to do everything fast and superficial. A rally will demonstrate that we are many...if we die, let's die fighting and let's make clear who took action and who did not...que sepan que estamos cabreados sobre el tema de la mineria, ellos mismos nos han enseñado a ser asi [they have to know that we are pissed off about mining, and they themselves have taught us to be like this]. 
Don Lucho was referring to the use of rallies and protest mechanisms to make authorities fulfill the promises of SD 0335 in the same way that Morales, before being president, did using the same methods. Don Joaquin, the current CORIDUP director, acknowledged the frustrations of people and stated that he would call for a rally if the majority demandedit. In the meantime, however, Don Joaquin asked the others to be patient and to see if the meeting in Oruro would solve some of the issues. As he later explained to me, he does not want CORIDUP to be perceived as an oppositional organization. For CORIDUP communities, this would mean receiving no public projects. Moreover, he also mentioned his concerns of being labeled as an NGO, which could also constrain their demands. As of this writing, no rally had taken place. I end this chapter with the closing words of Doña Ximena, a 29-year-old leader for the Sorachico community and the CORIDUP secretary. Just before the Comptroller's manager finished his grandiose closing remarks during the meeting in La Paz, Doña Ximena asked for permission to speak. Until then, she had remained quiet, as she usually did during regular meetings. The whole meeting she said nothing. Not one word. It was evident she was very nervous; she was shaking, tearyeyed and her voice was trembling, yet she still spoke up and by doing this, her speech, not the comptroller manager's, became the closing remarks for the meeting: Hermanos y hermanas, I ask for permission to talk. I want to share what is happening in our communities, because although I do not have any education, I can declare that contamination is affecting our lives, we can no longer survive, we produce nothing and we are still very poor. How is it possible that 
you, with all your studies, do not realize this? What's it worth to talk so much

if at the end we are still being contaminated? Hermanos, I ask you to take consciousness and do not make us come in vain; Don't you think we Don't have money? Don't you think about our babies? And how about our animals? All of this is very expensive and we come here to be in the same situation; no hermanos, if you want it like this, then you are forcing us to pressure you.

\section{5. Summary}

Chapter Five highlights the paradoxes between the discourse and praxis of the Bolivian state and its cozy relationship with the mining sector. Drawing on comparisons between SD 0335 and MML 535, participants' stories demonstrate that a new legal framework created during the MAS government, while including a discourse and policies that are pro-indigenous and pro-environment, also create inequalities that favor the mining sector at the expense of indigenous campesinx communities, the very communities the Bolivian state promised to uplift. A concrete example that participants emphasize is the fact that the Huanuni mine still does not have a tailing dam. Participants also narrated the paradoxical experience of feeling proud of the ethnic-based inclusionary policies of the MAS government while simultaneously experiencing class exclusions because of their class position as campesinxs, and particularly as campesinxs in opposition to mining extraction. Participants in this study, all of them indigenous campesinxs, described the emotional and historical significance to them and their communities of having an indigenous president, someone like them, and the relevance of having a government that promotes ethnic inclusion. At the same time, however, they 
also described overt and covert class-based discrimination led by the Bolivian state against them for being poor campesinxs.

In order to conceal and manage such contradictions, the MAS government has exacerbated existing inter-and intra-community divisions and created new ones. This divide and conquer strategy is complex, involving many actors at multiple levels. There are community divisions between miners and campesinxs, between local authorities and their communities, between Ayllus and their respective municipalities, and so on. Party affiliation-who belongs or does not belong to the MAS-has become a new central division that affects communities at both a personal and community-based level.

Moreover, these divisions are accompanied by an increased bureaucratization of life and of social movements. The new CPE, considered among the most progressive documents of this type, was drafted to give more autonomy to local governance bodies and indigenous authorities. Nevertheless, legalized autonomy for participants translates into layers upon layers of bureaucrats they have to deal with. To illustrate this bureaucratic process, I described a meeting that CORIDUP had in La Paz, Bolivia at the Comptroller General of the States' office. This meeting, like many others, did not include decision makers, therefore participants expressed their frustration that these meetings accomplish nothing, are a waste of time and seem like a deliberate effort by the Morales government to exhaust their socio-political demands. So far, it seems the government is succeeding at this. Yet, this is not the end. The next chapter presents the everyday resistance efforts of indigenous campesinx women to challenge these inequalities. 


\section{CHAPTER SIX}

\section{RESISTENCIA}

"Our community, our cooperation, and our care for one another are all loathsome to neoliberalism. It hates that which we celebrate. So when we say 'fuck neoliberalism' let it mean more that just words, let it be an enactment of our commitment to each other"

(Springer, 2016, p. 289)

"There is more to this reality that meets the eye," Laura, 36, a member of collective told me. She was describing the stereotype that many people have about women from the rural communities in the Andes as being shy, submissive, and naive. Yet, based on her work with women from the Poopó basin, Laura found a different reality. In the previous sections, I described the ways in which neo-extractivism affects the lives of indigenous campesinx women and their communities. I also described the ways in which the Bolivian state uses multiple strategies to crush indigenous communities' attempts to organize against the mining sector and preserve their ways of life. The list of all the barriers and difficulties that indigenous campesinx women and their communities must overcome to organize and resist is lengthy, not to mention the socio-economic context of the Andes, where these participants live in extreme poverty. People not familiar with the history of this region might perceive these struggles as a lost cause, another triumph of capitalism. Yet, this is not the end of this story, and this struggle did not start with CORIDUP. We collas [Bolivians from the Altiplano region] often joke that Bolivia seldom wins any competition. However, if the Olympics were to include protests and rallies, we would win. In other words, if there is a hallmark about Bolivia, it is class struggle epitomized by indigenous liberation. In this study, the 
everyday resistance of indigenous campesinx women epitomizes this.

Like Laura from Las Ramonas, I found another reality that is based on solidarity and resistance where indigenous campesinx women are vital actors, which I will describe next. My focus on this other reality is not an arbitrary choice using the power I have to tell the life stories of other people. Or maybe it is. Maybe it is my frustration with generic narratives of powerless victims of manifest destiny, or my own old narrative where legitimate resistance consisted of bombastic social movements only. Or maybe it is just a different lens that pays attention to the mundane events where resistance occurs in every day life, as social reproduction theory argues, and where indigenous campesinx women play a central role.

This section refocuses attention on the often-ignored daily activities of women as both subsistence producers and social reproducers to show how they engage in everyday resistance. To present these findings, first I describe the role of indigenous campesinx women within CORIDUP. Then I describe how indigenous campesinx women create solidarity networks that strengthen relationships between people and within and between communities, which become central in maintaining the social fabric of communities and Ayllus. In order to do this, I present the findings that show how indigenous campesinx women use a fluid and dual indigeneity, one that is capable of building alliances across ethnic, class and geographic lines to challenge and organize against the extractivist sector. I also present the experiences of indigenous women as leaders, where they describe how their daily life experiences intersect with knowledge gained from their leadership positions, as well as experiences with contamination. This intersection drives 
them to exercise their agency by challenging authority overtly and covertly. This chapter finishes with a portrayal of the community of Peñas in Oruro, Bolivia that represents the unthinkable about el Altiplano.

\section{1. Resistiendo aqui y ahora [Resisting here and now]}

\subsubsection{Resistencia popular [Popular resistance]}

CORIDUP (the Desaguadero River, Uru and Poopó lakes Defense Coordinator), the grassroots organization that represents more than 80 communities from four municipalities (Machacamarca, Poopó, Huanuni and El Choro) in the Poopó basin, represents a moment of significant grassroots organizing efforts against mining contamination. CORIDUP made national and international news because of its goals, particularly in relation to SD 0335 , which beckoned a significant and potential shift in the government's approach to the mining sector that has historically operated in Bolivia "with little oversight and scant regard for social and environmental impacts" (Horowitts $\&$ Watts 2016, p. 103). CORIDUP was also relevant because the very people affected by mining contamination, dispossessed indigenous campesinx communities, were the ones leading the protests. For reasons explained before, women also had a high participation in CORIDUP as both leaders and members base. What this participation meant varies depending on who one asks. Don Lucio, 55, from CEPA explained: "The consistency, support and accompaniment of women was decisive [during the rallies]; the police could beat the men, but not the women.” For Doña Ximena, 29, from the Sorachico community, there was much more to women's involvement. She described how Doña 
Francisca, a former CORIDUP leader, would organize women:

While we were preparing the food, Doña Francisca would also talk to us, she would tell us that we Don't have to be shy and that we have to speak in the meetings about our experiences... she would say 'hermanas, these are our lands, we have to do this thinking about our children, our communities, not just about us'... she would also tell us that we needed to participate in the rallies, that our hermanos needed our support.

Food preparation might seem a trivial contribution, but it is not. In Bolivian culture, as in many other cultures, food reflects not just what we eat. Food brings people together; it is the sharing and preparing of food that becomes like a frame that defines a picture, that defines a moment, as in this case, where Doña Francisca used this time to encourage women to participate in meetings and rallies. Doña Ximena also explained, "Doña Francisca would also use the radio as a main channel for communication, especially to convene people to the CORIDUP meetings." Most people in these communities do not have televisions or cellphones, but the majority has radios. According to Doña Ximena, this communication strategy worked really well — since Doña Francisca had been a CORIDUP leader, the meetings were high in attendance, around 40 to 50 people according to her estimates (the meetings I attended had between 12 and 30 participants). CORIDUP gained its highest momentum during the 2006-2009 rallies that forced preside Morales to approved Supreme Decree 0335 (SD 0335). This momentum has waned, at least for now. Some of the reasons for the decrease in mobilization are related to the inconsistencies around PCP (explained in Chapter Four). According to some (but 
not all) participants such as Doña Ximena, the current CORIDUP leadership seems hesitant about taking harsher actions against the government and against mining companies. Don Aurelio, 48, from Puñaka, Poopó, explained that "for rallies and protest measures to be successful, one needs people," and that is what communities lack (due to the high migration to urban centers). Moreover, under the current political atmosphere, organizations must be extra careful not to be labeled as "the opposition," since this could potentially create tensions with the government and other communities in the same region. The struggles against the effects of mining contamination however, are still ongoing through everyday resistance.

\subsubsection{Resistencia de cada día [Everyday resistance]}

Resistance is a buzzword, used and abused across disciplines and groups to describe a wide arrange of practices, particularly those related to social movements and protest, expressed physically as well as symbolically (Hollander \& Einwohner, 2004).

Resistance, as defined by Hollander and Einwohner (2004) has two core elements: action and opposition. It is not a state of being or a quality of an actor, but rather, action involves the active aspect of behaviors, "whether verbal, cognitive, or physical" (2004, p. 538). The second element, opposition, is a rejection, subversion, "counter" to something. These two core elements might seem self-evident, but it is not always so, especially since some scholarly work includes intent as part of resistance efforts. Scott (1986) for example, emphasizes the importance of paying attention to what he called everyday forms of peasant resistance, those unexciting but ongoing struggles of the peasantry 
against those seeking to oppress and exploit them. Scott's definition, however, is too focused on intentions, which are hard to analyze.

Expanding on Scott's demand for a focus on the everyday resistance of subalterns, Vinthagen and Johansson define everyday resistance as an intersectional practice that is historically intertwined to the heterogeneous powers it confronts and it depends on contexts and situations (2013). Everyday resistance, therefore, is a praxis that does not challenge a single power or is not trapped in a single power relation. Everyday resistance, therefore, is available to all subalterns, but it is not tied to them as subjects (2013). It is a constant and ongoing negotiations and challenging of power relations, where some subalterns will resist and other will not. It is also not whole; some power relations are challenged while others are not, and it emerges often within the realms of established power hierarchies. Everyday resistance therefore is both "subordinate and rebellious at the same time" (Vinthagen \& Johansson, 2013, p. 37). Keeping this definition in mind, the next paragraphs present indigenous women's practices of everyday resistance, which is not constant and wholly, as defined above, but rebellious, nevertheless.

\section{2. Redes de solidaridad: solidarity networks}

I met Doña Silvia, 51, during a meeting of her Allyu, San Agustin the Puñaka, that encompasses three communities: Yuracare, Puñaka and Picoya Isgualla. Don Silvia is a residente since she does not live in Puñaka anymore; she lives in the community of Huari, which is 1.5 hours away by bus from the Poopó town. In 2017 she became the corregidora (Mayor) of her Allyu, a position that includes administrative and judicial 
matters. Doña Silvia is a primary school teacher and she also helps other women around Huari and Puñaka to organize community events. The meeting were we met was held at the fishers' union office in Poopó, from 8:00 pm to 2:30 am. Yes, it was a six-and-a-half hour meeting. To keep traditions alive, people practice el Akullicu (to chew), an Andean tradition where people share coca leaves to chew and then keep them in their cheek. This millenarian practice symbolizes kinship and trust among those sharing the coca leaves (Lora, 2010). Because the coca leaf has many vitamins and minerals, this also helps people stay awake, this and Coca Cola, which has become part of these traditional practices. Sometimes people also bring a bottle of alcohol to share and sip with others in the meetings. By custom, before drinking one must first pour some drops to the ground as a tribute for Pachamama. Doña Silvia brought a small bottle of Caiman, a $96 \%$ alcohol beverage made in Bolivia from sugar cane. She shared Caiman with me throughout the night. The meeting had around 45 comunarixs and residentes, half of them women with them their wawas (children) and sheepskin to seat on. There were also four people from Senda, a non-profit organization that supports communities in the Andes with water quality control. Figure 16 shows the participants in this meeting and shows that meetings are usually separated by gender, where women sat on on side or section of the room and men seat in another section. Standing up is the Tata Mallku giving the greetings in Quechua.

This was also the first meeting where most of the discussion was in Quechua. Doña Silvia therefore explained the topics to me. I could also understand some phrases and words that my mom had taught me: "Nogayku casianku, moralmente matanchu" [we 
are morally dead], someone stated, and based on the context, it seemed he was referring to SD 0335 and how demoralized his community felt about the lack of actions to solve this issue. This person demanded that the thirteen Ayllus in Poopó organize and mobilize to make another law against mining contamination.

At 2:30 am there were no buses to go back to Oruro and the only local hotel was unlikely to open its doors so late at night, so my only option was to wait in the main plaza until 6:00 am, the time that the first bus departs to Oruro. Although Doña Silvia had just met me that night, she offered to have me sleep at her cousin's house where she was staying since she also lives far away from Poopó. Her cousin, Doña Asunta, was a former spokesperson for Puñaka in 2017. I was of course very grateful, especially since the house had only one free bed and Doña Silvia did not mind sharing that one bed with me as well. Doña Asunta and her family treated me like a special guest and in the morning they offered me hot api [quinoa flour tea] bread and butter. Doña Asunta's husband was not present since he was in the Puñaka community taking care of their animals. That morning we talked about random events, such as the upcoming popular festivities in a nearby community to celebrate the day of San Miguel's saint. ${ }^{77}$ According to Doña Asunta, San Miguel has the key to heavens and during these festivities San Miguel opens heaven's door; therefore this is a great opportunity to ask for favors and miracles. I asked what favor they would request. "Just a little bit of rain, not too much, not too little, just enough," said Doña Asunta. ${ }^{78}$ Then I asked if meetings usually last that long. Doña Silvia

\footnotetext{
${ }^{77}$ Religious syncretism in the Andes is widespread and common, particularly between catholic and indigenous practices. San Miguel 's saint festivity is one example.

${ }^{78}$ In 2014 floods in the Beni department killed a least 60 people and displaced around 60,000. In February 2018 Bolivia again experienced major flooding. The Taquiña River in Tiquipaya, Cochabamba over
} 
told me yes, "we always try to help others because we know how hard it is to travel, and especially to make time for the meetings and sometimes to find the money [to travel]. Even when it is last minute arrangements, we talk among us to see who has a space." I asked Doña Silvia how they organize these support networks and why; is it because they are leaders? She described:

Mama T'allas lead these efforts but women in general arrange such support networks ${ }^{79}$...nos organizamos asi siempre por debajito [we organize ourselves underground like this always], we Don't see it as a big deal because we are just helping each other. Before it was better. I remember growing up in Puñaka, when my mom was alive, her neighbors would come to help her grow potatoes, and then she would help them as well... comunarios are like that, we know it is in our own benefit to help others, but that is changing, now everything is money.

Doña Asunta also added, "we try to live like that, that's the way we do things... that is Ayni you know, today for you, tomorrow for me...that's why when I go to your house you will host me, right?" I replied, "yes of course", and then she added, "but instead of tea you will invite me lechon [a pork dish]," and we all laughed.

As I described elsewhere, Ayni is a socio-economic system based on the notions of reciprocity, complementarity and kinship that are central within Andean cosmovision

flooded destroying dozen of houses and killing at least eight people. This also produced floodings across Oruro and other cities (TeleSur, 2018).

79 When the meeting was over Doña Silvia told me that the Mama T'alla had extra payasas (dry-grass mattresses) and that she would host me for that night. But when Doña Silvia asked, the Mama T'alla refused to help. I do not know why since they spoke in Quechua. Doña Silvia found this unusual since the Mama T'allas are expected to help, especially other women. I think the reason is that I found out about this meeting last minute, therefore I did not request in advance permission to participate. The Mama T'alla therefore had no idea who I was. Before the meeting started, I had reached out to the leaders to explain who I was and what I was doing there, but someone referred me to speak to the Tata Mallku only. 
(Ravindran, 2015; Ayni Bolivia, 2018). In Doña Silvia and Doña Asunta’s accounts, women practice the Ayni by creating solidarity networks to maintain the social fabric within and between communities. Doña Ximena, 29, from the Sorachico community, also mentioned these types of solidarity networks. Doña Ximena is the CORIDUP secretary and she is one of the youngest leaders I interviewed. Doña Ximena lives near el Puente español, a checkpoint of the local customhouse that is located 1.2 miles south of Oruro on the shores of Lake Uru Uru. Like the majority of women who live in the city, Doña Ximena works in the informal sector selling food, drinks, and fruits. Doña Ximena described how during the CORIDUP meetings and mobilizations in 2008 and 2009, the women would be in charge of food preparation for the meetings and the trips to La Paz. She described that during this time women would talk about their lives, their needs, and they would find ways to support each other to participate in the rallies:

Sometimes I would go pick up Doña Elena because she could not walk very well. My husband had a car but he did not want to help. He told me it is a lot of time and gas, but I insisted; I told him 'one day your mom might also need help,' so we went to pick her up...then before the meetings we would gather and talk on how to reduce expenses and how to help the hermanas that had babies. I also have young children so I learnt a lot from other women. As Doña Silvia described above however, this is changing rapidly. For example, Doña Jazmin, 51, from Kochipiacala, Machacamarca decried: "Some [residentes] only bring your water if you pay them, they Don't do favors just like, it is not like before." Similarly, the narratives presented in Chapter Five, about the co-optation of 
community leaders point to these changes. Scholars like Lopez Flores (2015) and Webber (2017) argue that one of the social effects of neo-extractivism is that it has made territories like the Andes more susceptible to the logic of the market, exacerbating conflicts and divisions. At the same time however, Ayni expressed through solidarity, reciprocity and complementarity, is still present. The fact that Doña Paula from Kochia Piacala offered me a place to stay without knowing me, and asked for no economic compensation, even though she is poor, and the narratives above, attest to this. In fact, while doing the analysis for this study, I realized that solidarity and cooperation were ever-present throughout my fieldwork, particularly in the narratives of women. Although they did not refer to them as solidarity, cooperation was evident not only in their words, but also their actions, and also in my fieldwork observations and personal experiences with them.

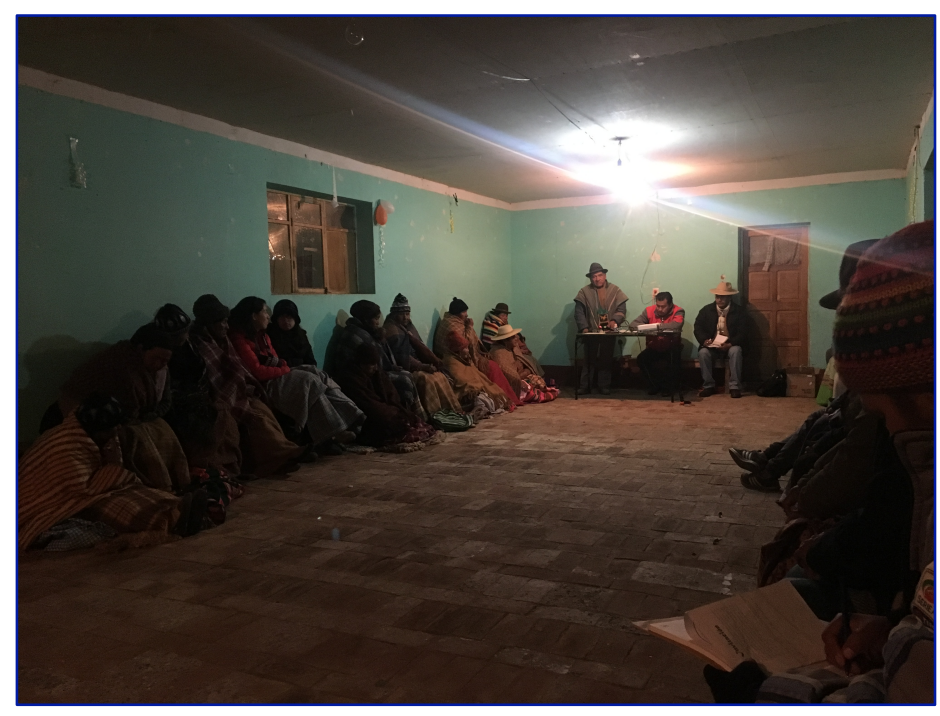

Figure 16. Meeting of the Ayllu Puñaka in Poopó, Oruro. Photograph by the author.

\subsubsection{Entretejiendo espacios [Interweaving spaces]}


Pellow (2016), like the contributors of a special issue of the Journal of Rural Studies on environmental justice and its rural dimensions, argues that the relationships and tensions between the spatial location of the urban and the rural are under-theorized. A “dominant cultural framework" in the Ecuador's central Andes, for example, uncritically links "rurality and indigeneity in a manner that locates then both as outside of modernity...[devaluing] them separately and in combination" $(2016$, p. 4). The experiences of women and other participants in this study elucidate how people constantly challenge these urban-rural dichotomies and rural-indigenous conflations, by expanding the meaning of what indigeneity means. In this case, indigeneity is independent from territorialities and acts as a bridge between the two seemingly unconnected spheres of urban and rural localities. This shows how indigeneity in Bolivia is a complex and a contested concept, especially since it relates to the majority of the Bolivian population and the state is using this concept to construct a national identity. All of the participants from the four communities in this study self-identified as indigenous. When I asked them "what does being indigenous mean for you?" their first response was "vivir en el campo" [to live in the countryside]. So what does indigeneity mean when people do not live in the countryside any more? How about residentes who are the majority of people in these communities who now live in the urban centers? Are they then not indigenous? "Being indigenous is not just going back to the countryside, it is much more" replied Tania, 28, from the Wasi Pacha collective to my question about indigeneity. Following up on this question, it became evident that for participants, as Tania argued, indigeneity meant much more to them. Doña Marcela, 60, from Puñaka, 
Poopó for example, shared the following:

That I live in the city does not mean I negate my roots...I cannot or do not want to cut my roots, I have that blood in my veins, I grew up in the countryside so I understand what it means to care for the animals, to harvest. I understand the countryside and I will always be a campesina. That's why I try to go back to continue growing food there.

Similarly, Doña Silvia, 51, from Puñaka, Poopó explained:

My conclusion is that the countryside has educated us, it has made us more conscious of life, it has taught us to value work, especially for me as I worked alongside my mother growing potatoes, to value Pachamama because thanks to her we can eat, so for me being indigenous means being a campesina, I Don't live in the countryside but I still value life in that way.

In her accounts, Doña Silvia and Dona Marcela articulate indigeneity not just as a connection to territories and origins but also as a praxis, a way of being and relating to their surroundings. While this indigeneity is independent from territoriality, participants also mentioned a strong desire to go back to their communities and a strong sense of connections to it: "La tierra te jala [the soild pulls you back]," stated Don Patricia, 43, from Puñaka, Poopó. She used that sentence to describe her resentment with her community and what happened to it: "When I left I was very mad, there was no more fish, we could not grow potatoes, we could not keep our animals alive so I promised to never be back and then I left." Nevertheless, as she explained, she started to think about where she wanted to spend her elderly years and about her children and grandchildren: 
"Where will they move, where will they go? How will they learn to value their land?" and that's how she reconnected to her community, regained her lands and eventually became a spokesperson for it. Similarly, Doña Laura, 52, from Caravi expressed that: Being a campesina is to recognize where we come from, to look at our origins, and not to just say one is Indian but to act like one, to not discriminate, to think about our ancestors, and to work to achieve something good thinking about our dreams and our children, to look for the future. This does not mean to go back to the past, to the cave times, but to recognize who we are.

Doña Laura's account of indigeneity is intriguing since like the other accounts her indigeneity is not trapped in a locality, it is a verb. It is also not trapped in the past, as she seems critical of that romantic, and racist notion that is unable to think of indigenous peoples as modern subjects. Such flexibility with indigeneity has allowed people to mantain connections with their communities. These narratives as well as the experiences of residentes and the double residency practices described in more detail above, are examples of this fluid indigeneity. This flexibility with indigeneity has also allowed indigenous communities to create important alliances to confront and resist the destructive impact of extractive capitalism. The following section presents the experiences of participants, with a focus on the experiences of women creating these alliances.

\subsection{Fusing divisions}

In one of the meetings of the Kochi Piacala community, Don Miguel introduced me to his nephew Mario, a witty 33-year-old man who has a degree in engineering 
systems. ${ }^{80}$ After some chatting, Mario invited me to an event that his collective, Wasi Pacha (the House of Earth) was organizing. The next day at the event, I met Tania, 28, and Sabrina, 36, who along with Mario, are Wasi Pacha's founders. I really liked how the event, a music and poetry show at a local café in the city of Oruro, fused arts, global issues and politics with local struggles. This event hosted different local artists who talked about water contamination in relation to the drying up of Lake Poopó. After this night I started participating in Wasi Pacha's events more often.

Wasi Pacha was created in 2016. The collective has approximately 16 members, the majority women, and its goal is to provide training, awareness of local environmental issues, particularly mining contamination, and to promote the defense of Pachamama, with access to clean water as a central concern. "It also focuses on the re-valorization of ancestral knowledge to understand and create alternatives to the current system, capitalism, and not to just use theories from the West," said Mario. Figure 17 shows a seminar organized by Wasi Pacha to plant trees around the Machacamarca municipality. These activities usually include food, and the picture to the left shows participants sharing the food they brought. The pictureot the right shows a participant collecting water to wash dishes.

Wasi Pacha has close relationships with local communities, especially those that are part of CORIDUP. It was Tania who introduced me to Doña Victoria, 49, my key contact for the Poopó region, and Mario is the nephew of Don Miguel, my key contact in Machacamarca. As many collectives in Bolivia, Wasi Pacha aims to be independent from

\footnotetext{
${ }^{80}$ The percentage of people with a higher education degree in Bolivia is similar to the percentage of people with higher education in the US: One third of the population. Moreover, in Bolivia public universities like UTO (Technical University of Oruro) are known for providing, quality and critical education.
} 
NGO funding, which means they do not have a budget, but they do rely on grants or fundraising events.

Mario, Tania, and Sabrina self-identified as indigenous and they met during a young environmental leaders' seminar organized by CEPA. They all lived in rural indigenous communities for a short period of time during their childhoods, and then moved to the city of Oruro. Throughout my conversations with them and the activities they organized, it became clear that they are directly and actively connected to their communities. Although their communities are not part of CORIDUP (except for Mario's), they might be potentially affected by mining contamination, which in Oruro seems to be the path for the whole department. Sabrina, 36, explained:

In Oruro, [mining] contamination is everywhere, visible and palpable. In the north you can see the mining residues of the San Jose [mine], in the south is the Hitos [mine], to the West you can see what is left from Kori Chaca [mine], it is really big, and in the East the Tagarete channel carries the acidic fluids from the San Jose mine that go straight to Lake Uru Uru.

Sabrina told me that in 2017, the San Luis mining company had plans to start extracting silver by building an open-pit mine nearby Sillota Toloma, her mother's community. For reasons unknown to her, this project was not executed. Tania, 28, also shared that his grandfather, the Ayllu Mayor of the Choquecota community, requested an emergency community meeting in 2017 to talk about the Chinese company De Cobre and its plans to start mining around this Ayllu. 

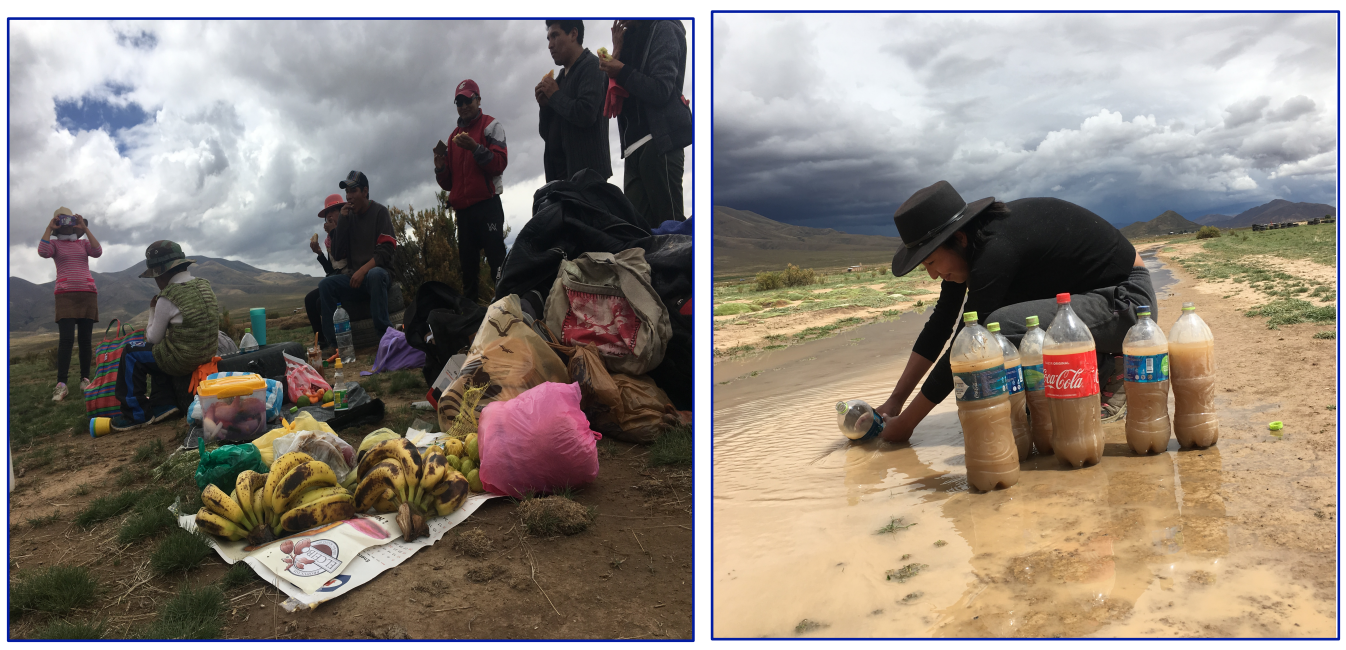

Figure 17. Wasi Pacha seminars and workshops. Photographs by the author.

I asked them how and why they started organizing, and if there was a turning point in their lives. They shared a similar perspective to other participants about the connections between their lived experiences in Oruro and the knowledge they gained through their leadership positions. Tania, 28, expressed:

My dad did not want us to learn anything about being indigenous or rural communities, so we were de-classed. I did not understand the relationship to the land, the countryside, even though I spent a lot of time with my mom in Choquecota, but then as part of the [CEPA] seminar, I listened to the stories of CORIDUP...the lack of water, and then there were the presentations of CEPA and CEDIB [two NGOs] about mining companies and how they corrupted local leaders and how much profit they make while the communities receive nothing...That was a vital moment in my life: 'how is it possible that my parents are from the countryside and I Don't know this reality?' I was traumatized by the impact of [mining] contamination, and then I start asking questions about what could be done and I started thinking about solutions. 
Similar to Tania, Sabrina explained that while she was participating in the CEPA seminars, her brother had an auto accident and a pine tree stopped the car, saving his life: “That moment I thought I have to do something, that tree saved my brother' life and then I started making the connections between trees, water, Lake Poopó, my parents' communities and my life." Mario explicitly pointed out his family connections:

My grandmother used to cook pisara [toasted quinoa], mukuna [toasted and friend quinoa with sugar]; she would also made tayacha [quinoa ice cream], so although before I would not go to the countryside because I was ashamed, that connection was kept through my grandmother, and it was those memories that later on would move me to take action.

I also asked them specifically how they made these urban-rural connections since they grew up in the city of Oruro. Mario replied:

Especially in Oruro we are so reliant on food from the countryside, quinoa, potatoes, meat, cheese, milk so people Don't realize how contamination has a direct effect on us, plus it is also the injustices that communities face and many times they can't do anything because they lack the resources, so they need our support.

For Sabrina it was a generational connection:

There are many young people who feel ashamed of being indigenous and want to erase whatever link they have to their communities because that still means backwardness, but there are also people like us, who have deep ties to the communities through their families, so many are turning their sights back and are 
reconnecting to the communities in different and creative ways.

Sabrina's impressions seem accurate. On one hand, much of my family for example, especially younger generations that live in Oruro and had similar life histories like Sabrina's (parents from rural and indigenous communities, being indigenous urban migrants), showed no interest on making these connections. On the other hand, in 2018, I danced and played with Sartañani, one of the 150 music bands that participates in Oruro's carnival, Bolivia's biggest and most famous celebration. ${ }^{81}$ But Sartañani is not just a musical group; its complete name is Cultural and Autochthonous Center Sartañani Wasuru Qhananpi [raise up with the light of yesterday]. Sartañani uses music and arts for cultural revitalization. Figure 18 shows some of the activities that Sartañani promotes such as participation in Oruro's carnival (picture to the left) and meetings promoting cultural revitalization. The picture to the right in Figure 18 shows a reunion of Mama T'allas and warmis (women).

For the carnival it was mostly young people from the city who participated in the band, both men and women. We would gather together a few hours before rehearsals to prepare food and to just hang out. Listening to their conversations, a dominant theme was how to connect that which for many belongs to the past (culture and traditions) to a present that includes that past but also fosters a new future. As Marcelo, a young Tata Mallku in his thirties from Sartañani, mentioned, "some of our elders get mad when people do not wear the traditional clothes, but we are trying to be flexible because our times are changing, and the clothes do not define who we are or what we value." During

${ }^{81}$ Oruro's carnival is also a UNESCO Masterpiece of the Oral and Intangible Heritage of Humanity. 
the final rehearsal, I listened to a young man in his late twenties, and a member of Sartañani, discussed the following:

Tatas y hermanos [fathers and brothers, it was a group of men], music and revalorization is good, but mining should be our main struggle too. Look at Lake Poopó, and now my grandfather's community. Some of you are Tatas and you can make an impact. We are Orureños, this has always been the struggle.

I could not hear the name of the community he was referring to, but like the communities of Tania and Sabrina, his grandfather's community was threatened by a new mining concession. ${ }^{82}$ These conversations were common among these young people who were making the very connections that Sabrina explained.
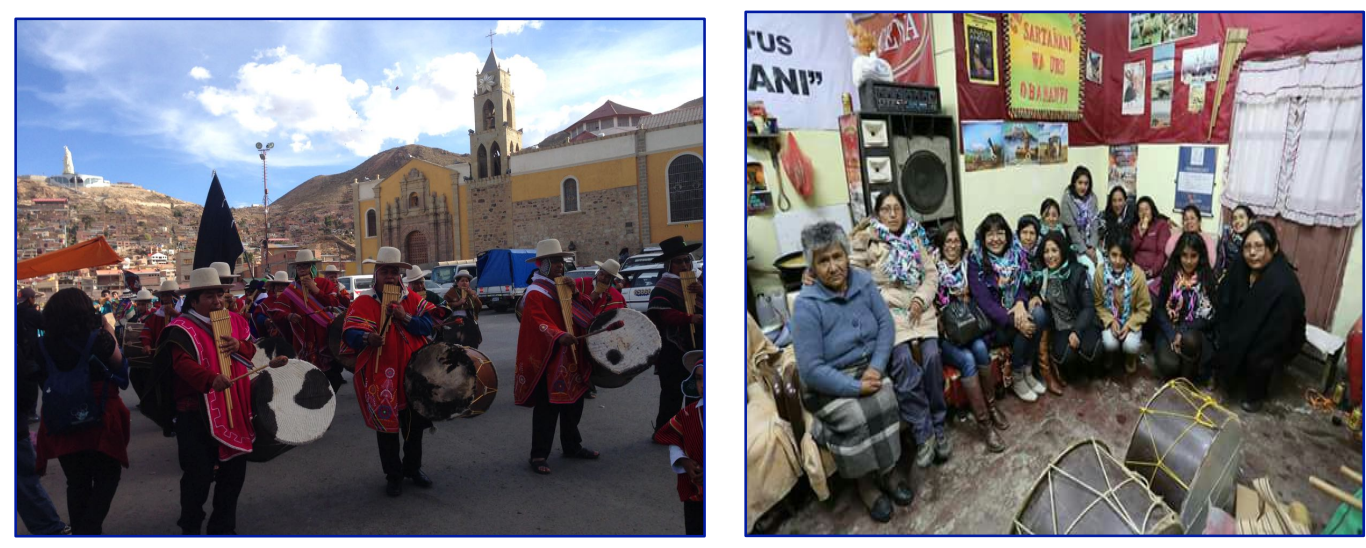

\footnotetext{
${ }^{82}$ As mentioned before, many communities in Oruro are threatened by possible mining concessions that seem to be granted by the state with no previous and informed consent. In 2018 I observed the election of the new leadership and celebration of the Jach'a Carangas Suyu nation, of the best-known indigenous nation in this region. During the celebration, a tata Mallku from the San Miguel Ayllu expressed his concerns about mining concessions in his Ayllu that were granted with no informed and previous consent, as it is stipulated in the law. San Miguel is a TCO (Communal Indigenous Territory), which means indigenous communities have more rights and more autonomy over their territories. Besides, San Miguel is part of the Jach'a Carangas Suyu, also known as the indomables ponchos verdes [unruly green ponchos] in reference to their historical resistance and organizational capacity against colonial powers (CEPA. 2012). Jach 'a Carangas was also heavily involved in the mobilizations of 2000, 2003 and 2005 that paved the way for the Morales presidency. For these reasons, many people were surprised and extremely disappointed about these allegations of unapproved mining concessions by the indigenous nations.
} 
Figure 18. Sartañani Wasuru Qhananpi, Cultural and Autochthonous Center. Photograph by the author.

For Tania, it was the impact of mining contamination on women: "When I learned the extent of mining contamination, I realized that it is always women the most affected since they have to deal with getting water, cooking, feeding the animals; no wonder why women are the most resistant against mining companies." When I asked Tania what she meant by the most resistant, she explained:

For example when we had that meeting about the Chinese company in my grandfather's community, I sat by the women' side because the meetings are kind of divided by gender right? And the women, without me influencing them, were very decisive about saying no to the mining company, and that called my attention because that reflects the consciousness that a natural resource like water, something so basic, so essential, can raise consciousness. But since men do not live that reality, then they were more ambiguous about letting Del Cobre [company] work there.

\subsubsection{Hermanadas [Sisterhood]}

Like Wasi Pacha, is another collective from Cochabamba that works on similar issues and is making similar connections. I learnt about because a documentary they made called "Yakurayku Puriqkuna" [walking for water] about Lake Poopó drying up and its effects on indigenous women. The goal of this documentary was to create a wakeup call about the impact of mining contamination on Lake Poopó. According to the dominant narrative spread by the state has been that of climate change, which did affect 
the drying up of Lake Poopó. Nevertheless, this narrative ignores the role that the Bolivian state and mining companies had in worsening this situation, the former by not implementing mitigation policies when this issue was raised years before; the latter by diverting the waters from rivers leading to the lake and also by contaminating the waters leading to it. Unlike, do not have that kinship connection to rural communities, and not all its members self-identify as indigenous. Yet, as young women from the urban city of Cochabamba, they too find a strong interdependence between their lives and the lives of indigenous campesinx women in the Andes. Holga, 32, explained that their name is in reference to comandante Ramona from the ELZN (Zapatista Army of National Liberation in Mexico). As she explained, their mission is to promote autonomy and auto-gestion [self-management] from the perspective of women like them without disconnecting theses struggles from the struggles of campesinxs. Before founding, Holga and Laura, two young women in their early thirties, participated in the water wars of 2003-2005 and other protests. For them, the turning point of creating a collective with a focus on indigenous struggles was the TIPNIS conflict and the connections it reflected about the state and intersecting systems of oppressions. Holga explained:

TIPNIS was the breaking point to see that the MAS government was not indigenous, or pachamamista, but rather it was still a very savage capitalist one...We believe that in Bolivia we have a colonial, patriarchal and capitalist problem, so we address these problems from our feminism, therefore creating a struggle that is anti-colonial, anti-patriarchal and anti-capitalist...but we are also guided by the Zapatista principle that states that age, gender, race, or ethnicity 
does not matter as long as one is fighting for the struggles of the people. Guided by this principle, they decided to work in collaboration with indigenous campesinx women from Poopó to produce the documentary mentioned above. Laura further elaborated this point: “The communities want to fight but they can't because of the high migration they experience and also because the government supports the mining sector. There is also the historical memory and the importance of miners in the political life of Bolivia; that's why the women in these communities welcomed our support." Laura also described the gender connections in their work:

I find it very interesting how women are jumping outside the city-countryside divide; it is as if we are making an interweaving that is not just about class or race issues, but now is gender, women working with other women. For us it was amazing to work with women from the Poopó basin and to break stereotypes. People imagine women from the Andes as shy, quiet, but not at all, they are very strong and committed... and the food, the potatoes we shared, it was like breaking everything to be there, to feel, to be united, realizing we are all affected by the same situations, and although we live in Cochabamba, we felt connected.

Doña Victoria, 49, a former Mama T'alla from Quellia, Poopó, also participated on the documentary produced by . As I described in the methods chapter, Doña Victoria is a well-respected leader in this region and within CORIDUP. She is a residente of Quellia; she lives in La Paz, and she constantly travels back and forth between Poopó and La Paz because she still has lands in her community and because she is a small trader (she sells 
clothes and small kitchen supplies). She was my key participant in Poopó who helped me contact other participants. During my interview with Doña Victoria, she explained:

It is really hard to do something or to stop the contamination; that's why we feel very motivated by the support of other people, especially our hermanas from Cochabamba. La hermana Holga [from ] has been really nice and helpful in this; she would explain to us how to test the water and she made many documents about what's happening here. She also did that movie. Anytime she comes here we laugh and eat a lot, we consider her part of our community.

\section{4. It is chacha-warmi, not warmi-chacha}

The Andean concept and practice of chacha-warmi (male-female) is based on duality and complementarity where the masculine and feminine complement each other. Chacha-Warmi gives importance to the feminine, and brings it as an equal complement to the masculine, in theory. The complementarity of equals within Andean cultures is reflected for example in the world of deities, such as Inti and Phaxi Mama, the sun god and the moon goodness (Choque Quispe, n.d). The complementarity aspect of two equals "is materialized in the social process of Taqikunas panipuniw akapachanxa [in this world, everything is in pairs]" (Quispe, n.d., p. 2).

For this study, chacha-warmi is reflected in the high number of indigenous campesinx women as leaders, particularly since Tata Mallkus (male indigenous leaders) must have a counterpart: Mama T'allas (female indigenous leaders). Although my plan was to interview three female leaders (who others referred to as key community actors), it was a surprise to find that 16 out of the 17 women that I interviewed held some 
leadership role within their communities. Doña Elena, 68, was the Jilakata [maximum indigenous leader] of her Ayllu twice; Doña Victoria, 49, and Doña Karina, 53, from the Poopó municipality were Mama T'allas for their communities, and Doña Silvia, 51, was the corregidora (Mayor) of the San Agustin the Punaka Ayllu, to mentioned a few examples.

On its side, the MAS government has also promoted gender equality through for example, the creation of the 2008 National Plan for Equality and Opportunities "women building a new Bolivia to live well”, PIA for its Spanish acronym (Ministerio de Justicia, 2008). Evelin Agreda Rodriguez, former vice minister of Gender and Generational Affairs, stated that PIA is a development plan drafted by different women-led organizations. PIA's main focus is to recognize the central role of Bolivian women as well as to promote their participation in all aspects of society (Ministerio de Justicia, 2008). Las Bartolinas, the National Confederation of Campesino, Indigenous, and Native Women of Bolivia and the largest women-led organization in the country, embodies PIA's mission. Las Bartolinas was founded in the 1980s and its main goal is to promote the participation of women, particularly indigenous women in the political life of Bolivia (Rousseau, 2011), and they made possible gender parity requirements in the CPE that led to a $51 \%$ of women in the chamber of deputies and $44 \%$ of women in the senate (Sanchez Echevarria, 2015). ${ }^{83}$

\footnotetext{
${ }^{83}$ Las Bartolinas participated in the creation ${ }^{83}$ of the MAS party and they have continued their support to President Morales. Such unequivocal support has brought them criticism. Las Bartolinas Nevertheless, they have received criticism by other indigenous organizations for being MASistas (being from the MAS party) and because they did not distance themselves nor publicly reproach the government for its violent repression of protesters, the majority indigenous people of the lowlands, during the TIPNIS conflict.
} 
What does this gender inclusion mean for the indigenous campesinx women in this study? In theory, chacha-warmi represents the complementarity notion of two equals and the government's promotion of gender equality seems based on this notion. In practice, however, it reflects and continues unequal gender relations. To start, the Tata Mallku and Mama T'alla positions are usually given to couples (married or in formal union). As Sabrina, 37, from Wasi Pacha described: “This translates into Tata Mallkus being elected and recognized as the central authorities by their communities, while Mama T'allas get their position through their partners," therefore their legitimacy is reduced to a complementary and secondary role to the Tata Mallkus. The duties of this secondary role are limited to handling the logistics of meetings, such as finding a place to meet and taking care of cleaning the space and food, while Tata Mallkus are decision-makers.

This, however, is changing. Mama T'allas now can be single, and the communities can directly elect divorcees or widows. At first glance, this seems as a progressive step towards gender equality, but it is not that simple. Leadership positions usually last 12 months and one is expected to accept these roles: "When the community elects you, you can't say no, you have to do it for love to your community," stated Doña Amalia, 35, from Quellia, Poopó. twelve months is a short time and barely allows for anything to get done, but this timeframe still requires a significant investment of time (meetings, trips to the main cities, visits to communities, etc.) and resources (transportation costs primarily, as well as provision of food for meetings if necessary). ${ }^{84}$ Couples do share these responsibilities, whereas widows, or single/divorced women have

\footnotetext{
${ }^{84} \mathrm{~A}$ community leader explained to me that although people know it is better to have longer positions to accomplish and follow up community projects, they are also well aware of the hardships that leadership demands. Therefore, they limit it to 12 months. Leaders and their communities might decide for re-election, which happens frequently. 
to bear all these tasks and expenses on their own. Doña Jazmin, 50, from the Kochi Piacala community, captured this reality:

Gisela: Can you tell me how you were elected and what it meant for you? Doña Jazmin: Yes, so I am single right? I did not know I was elected because I didn't go to that meeting, so when I found out I cried a lot. I thought 'I Don't have a husband, so how am I going to do this alone?' It is a lot of time, and you have to travel to the cities a lot, and sometimes I did not have anyone to take care of my animals, and no one would do it for free. As a leader you have to come and go, pay for the bus tickets bs. 5 (\$US 0.75 cents) every day, it is a lot. You have to walk a lot if you are alone, like a lot!! It is not easy...even the food, I didn't have money to buy food so I would take just my coca [leaves] and with that I would be all day until I came back here.

In addition to the material barriers to participation, women in general face the barrier posed by entrenched patriarchal culture. Women like Doña Laura, 52, from Caravi expressed it thus:

Men are always machistas, they want women to just take care of children, of the livestock, to be at home while they go to the meetings...so sometimes your husband is the one who tells you 'you will fail, you won't be able to do it [be a leader], everyone will laugh at you, Don't be a fool.' Your partner is the first one to discourage you; that happened to me, so sometimes it is better to be single. ${ }^{85}$

\footnotetext{
${ }^{85}$ There were also some accounts of tokenism. In one community meeting that I participated new leaders were being elected. All of the women in the meeting pleaded not to be elected. Then someone stated, "we need a woman for gender equity, if not others will say there is discrimination". Besides, during the interview with Don Lucio from CEPA, I asked him why women were important during CORIDUP rally to La Paz. He replied, "the support of women was decisive, they [the police] could kick men when we were
} 
Women also explained that the Mama T'alla role denotes other relationships and responsibilities. Mama in Quechua means mother (and Tata means father), therefore this role also alludes to a parental relationship with the communities: "I found out it [mama] means a big respect, a big role because you are like the mother of the community. Therefore, I have to think about all comunarixs like my own children," described Doña Jazmin, 50, from Kochi Piacala, Machacamarca.

When addressing internal community divisions such as those between miners and campesinxs, this father-mother notion is ambiguous. As Doña Jazmin later explained, "because Tata Mallkus and Mama T'allas are parent-like figures, they have to seek the well-being of everyone in their communities, the good and the bad." This makes it harder for leaders to solve disagreements about mining contamination and even harder to find a middle ground solution, as leaders are not expected to take sides with any faction. Understandably, mining contamination is a very delicate issue that Mama T'allas must navigate, particularly in the Poopó municipality where many comunarixs have been or are involved in mining activities. Nevertheless, participants like Doña Amalia, 35, a Mama T'alla from Quellia, Poopó, questioned this:

As I told you, what I have seen here [in Poopó] is that the people who are with you are not decisive as people in Qaqachaqa where I am from. I think one has to be decisive for good or for bad: o bien muere la minería o bien muere la agricultura [either mining dies or agriculture dies], but not like

blocking the streets, but they could not kick out the women" and that was the main point he highlighted about women. There are also stories of gender bias between Tata Mallkus and male government officials. As Doña Elena, 68, explained "I went to the meeting in Oruro, then the environmental technician started talking just to my Tata Mallku, but not to me, and then my mallku instead of saying something, he continued, and then they started making jokes, start talking just between them, I tried to talk but they ignored me". 
this, today one thing, tomorrow another, they [comunarixs] turn their back on you and nothing is accomplished. That's what is causing us to fail.

One may question Doña Amalia's comparison between these two communities since they have different histories; Qaqachaca has not experienced any mining contamination and not a strong rural diaspora like Quellia. In Chapter Four, I presented Doña Amalia's description on how Qaqachaca is able to grow many crops because it is not contaminated, whereas in Quellia it is hard to grow anything. However, Doña Amalia's point about the ambivalent role of Mama T'allas is well taken. While Tata Mallkus and Mama T'allas have the ultimate authority over communal decisions, it seems that the tensions between miners and peasants within communities usually lead to leadership inaction, and this favors the mining sector.

While the extent to which chacha-warmi facilitates gender inclusion is open to question, what women described about their leadership experiences shows an earnest commitment to fulfill their roles to benefit their communities. Doña Elena, 68, is the Jilakata of the Sorachico Ayllu whose story I described in detail before. She shared the following about her leadership role:

He [the mine's manager] told me 'come to the office, we will talk.' He wanted to offer me money to be quiet, but I said no because I swore two times as a Jilakata, and those two times I promised that I would never betray my community, never, nor my Ayllu nor the people around me. I would never do wrong, I respect the promise I made, that's why I did not accept, but there are other leaders who are bought-out, but not me, my consciousness would not 
allow that.

Doña Elena also reflected on the short- and long-term consequences of such actions, not just for her, but for her community: "I can not accept money because right now I might be OK, but later? My lands will still be contaminated, my animals sick, my family never able to come back, my community destroyed, so I said no, I have to be strong."

In the previous paragraphs, Tania, 28, from described how the women in her community were sturdier than men in their decision against mining explorations, and she attributed this to water's impact on the activities of women. This view was not uncommon. Don Luis, 43, from CEPA also reflected on this:

In these five years I think there is more mobilizations about water contamination by women; I think there is some articulation of women's networks; women have more information and capacidad de gestion [management capacity] and impact...women are the ones most impacted by it [water contamination], and women are more connected to their territories, they Don't leave so easily. Men leave seeking work opportunities to other countries, but women can't, they have to stay with their children, so I think that creates more consciousness from women and that's visible.

\subsubsection{Commitment}

One early morning, around 5:30 am, when I was staying with Doña Paula, she asked me to bring clean water from a small water well that was near since we did not have water to wash dishes. She also needed to stay at home to feed a wild pig and her piglets that had started coming to her house looking for food (Doña Paula would later 
sell the pig to her cousin). It was a 12-minute walk (one way) to the water well and although mornings in the Altiplano are very cold, I enjoyed it. It was refreshing, a peaceful solitude between the mountains, the two empty plastic oil containers that I carried to bring the water, and myself. On my way back I ran into Doña Jazmin, 50, a comunarix that I had not met before. We chatted for a little bit and then she invited me to eat lunch at her house. After helping Doña Paula peeling potatoes and washing some dishes, I went to Doña Jazmin's house. She lives alone, and she is the only woman I met who is single with no children. Unlike Doña Paula whose mud brick house has a small room where she cooks, Doña Jazmin's brick house is just one room. Therefore, she cooks on a small anafe (kerosene-based Primus stove). She apologized for the food being eggs with rice only: "I am sorry for the food, it is the only thing I have to share," she said, which made her invitation even more meaningful. Doña Jazmin has lands she inherited from her family in three different communities-in Kochi Piacala where I met her- in Santa Maria and Chaykata. ${ }^{86}$ This means she is a residente of these three communities. I already shared her account of being a leader and a single woman, where she described crying because of the duties this means. Doña Jazmin, however, also demonstrated a strong commitment in becoming a leader: "I was sad and worried, but my heart guided me, I didn't even finish school, I felt like I was blind, but still, I could not say no to my community, if they choose me then I had to do it, and I told them 'if I take this to die, you too will

\footnotetext{
${ }^{86} \mathrm{I}$ am not sure this is the right spelling of this community since Doña Jazmin did not know how to spell it either. It is also hard to find maps or information about political and geographic divisions at the community level.
} 
die with me, I will protect you and you will protect me."” Doña Jazmin also shared how she learned to own her leadership role and to demand respect:

To be a good leader you have to learn to be insistent, so in the public offices I would insist that people explained things to me, because I did not know, and although people were impatient, they did explain these issues. Also, with my credentials as a leader I learned that I could go into any office, as if it was my house, I was like the owner of the house, although I was really nobody. Doña Jazmin's reflections were based on her leadership roles (both as Mama T'alla and spokesperson) for the Choycata and Santa Maria communities. These communities are not heavily affected by mining contamination because of their upstream location. They have had therefore less migration. About Kochi Piacala, Doña Jazmin shared the following:

Doña Jazmin: I know how hard it is to be a leader... as part of the base, I try to support my leaders as much as I can. If they have meetings, or if they need signatures or whatever, I always support them.

Gisela: And you Don't want to be a leader here [in Kochi Piacala]? Doña Jazmin: No, I am taking a break from leadership because I still need to finish el fondo in Choycata.

Gisela: El fondo? You mean el fondo indigena [the indigenous fund]?

Doña Jazmin: Yes, I have an [ongoing] project with sheep, we give each comunario one or two [genetically] improved sheep, and in Choycata there are 70 comunarios, so I am working on that, but it is a big headache. 
Gisela: Why is that a headache?

Doña Jazmin: You know about the scandals, so I was told my role is like that of a mayor, I have to take the lead, I have to take care of the money, so I had to hire an accountant, and some people told me I was screwed, that accountants would take advantage of me and that I would go to jail. So I cried, and I prayed to find a good person, and I did find a young guy who is honest and is helping me.

Doña Jazmin's concerns about the indigenous fund are justified. In 2015 news emerged about corruption scandals where more than \$US 6 million were missing in "ghost" projects and another \$US 14 million from the indigenous fund were unaccounted for, an initiative by FILAC, an international organization that supports social and development projects for indigenous communities. The people involved in the corruption scandals were high government officials from the MAS party, including the former minister of justice and rural development. After this scandal, the government has acted with a heavy hand (prosecution and jail time) for any corruption related to the fund. This, however, has mostly affected people like Doña Jazmin who manage smaller amounts from the fund.

\subsubsection{Speaking truth to power}

The women I interviewed were aware of how gender, class and ethnicity intersected and placed them at a disadvantage in these struggles. Dona Jacinta, 57, for example, is the former finance secretary of Alantañita, Machacamarca. She went to school only until third grade and then had to drop out because her family needed help 
with livestock. She lives in Alantañita permanently but travels often to Machacamarca to get clean water. She explained:

The first time I went to the Ministry of the Interior, I was scared, I thought 'a humble woman like myself here? soy campesina' [I am a peasant], I could not even speak! My friend would write for me what I needed to say and I would stutter, but he would make me practice and then I started learning.

Like other women leaders who never imagined themselves as leaders, Doña Jacinta described how the knowledge gained from being a leader, combined with the experience of the effects of mining contamination in her life, motivated her to take action: "I learned that a good leader has to push, has to demand things. A good leader has to go to the government and has to speak about the harsh life in our communities. A leader has to make demands every day for everyone."

It caught my attention that many of the participants would refer to la conciencia when speaking of their experiences. ${ }^{87}$ In the previous paragraphs for example, Doña Elena mentions how her conscientiousness would not allow her to take bribes from the mining companies. It was difficult for participants to articulate what this conscientiousness meant, yet they talked about this as a type of feeling, an awareness of their situation, and a strong ethical sense of what is right and what is wrong. Nevertheless, it was not just awareness. Participants highlighted the active part of la conciencia. To illustrate, Doña Ximena, 27, from Soracachi stated "I have always been conscious and that's why I try to do my best, that's why I think it is unfair that the

\footnotetext{
${ }^{87}$ Conciencia in Spanish means consciousness, as the awareness one has about his/her/their (social, political) position within society. It also means conscientiousness and conscience in reference to integrity and morality. Participants expressed la conciencia as multi-layer, representing either or both definitions (consciousness and conscience), or only one.
} 
[mining] company contaminates our lands without thinking about us, I could not do that to another person."

It was also from this place of conscientiousness that women challenged other authorities: "Yo tambien me discutia con ellos," stated Doña Elena, 68, from her experience as a Jilakata of the Sorachico Ayllu. This phrase translates into "I myself also argued with them" which is a reflexive sentence. In Spanish, reflexive verbs and sentences are used for actions the person (we, I, she) does to herself/himself. In this case it is a way to own one's argument, and give a central role to the person [the I] in the argument. In this manner, Doña Elena highlighted her active role challenging assumptions, and sometimes plain lies, by people in power:

I was a Jilakata for two years, and then in a big meeting I told engineer Rada (from the Ministry of Rural Development) the truth to his face. He was saying that in my Ayllu, Sorachico, they [government] Donated tools, and that they made wijiñas. 'We helped you, and you still complain,' he said. In that moment I interrupted him, and I said 'I request permission to talk. You, engineer Rada, need to speak the truth...you said you Donated tools, but you did not, you sold them to us and your tools were old and some of them did not work.' In that moment he looked at me as if he wanted to kill me, uhh his eyes were furious... and he started quarreling with me, but I did not let him do that, I myself also argued with him.

Women seemed especially proud to share their stories about challenging the assumptions of government and/or private sector representatives with credentials, such as engineers, 
technicians, doctors (in reference to lawyers or accountants) and people with some type of degree. Doña Patricia, 43, the water monitor from Puñaka, Poopó shared:

It did not take long before I started arguing with them, and then I started arguing with authorities, even the licenciados [the ones with degrees]...I would argue with them because they think we know nothing, but we do. We have to deal with this [contamination] every day. We also received workshops so we understand better. Before I was not paying attention, I did not think it was that serious, but as a leader I realized it was, and you know, 'wawa que no llora, no mama' [the baby that doesn't cry does not suckle], so I started demanding things, and they were mad that we were not quiet.

\section{5. Creating the impossible}

The power asymmetry of the conflict between mining companies, the state and indigenous communities creates a sense of futility regarding the inevitable disappearance of indigenous campesinx ways of life. The "natural" harsh environment of el Altiplano might seem to favor such a sense of inescapability. Regarding the question about the future of their communities, participants shared ambiguous and often contradictory responses. Notably, it was male participants who argued for example, that Allyus and communities be classified as mining rather than agricultural areas."My personal opinion is that we should leave agriculture to the side and declare our Ayllu a mining area because we are rich in natural resources. At least this way our communities would receive something from the [mining] rents... right now we are going like the salmon against the current" declared Don Aurelio, 48, the Tata Corregidor (Major) of the San Agustin 
the Puñaka Ayllu. For women, the future was uncertain, but none of theme expressed a desire for mining to become the predominant socio-economic activity in their communities. They did express a sense of frustration, and also a sense of hope: "This is a long struggle, it takes time, and to be honest I feel sad about the future, but the important thing is that we have already started fighting, right?" expressed Doña Laura, 52, who is the treasury secretary for the Caravi community situated on the shores of the Desaguadero river.

The MAS government has popularized Sumaq Qamaña, or living well, as its leading philosophy and a core principle of the CPE that guides people to live in harmony with nature and with other humans beings (Artaraz \& Calestani, 2015). Often ignored in this conceptualization, however, is the radical side of Sumaq Qamaña as a serious questioning of and as an alternative to economic development, modernity and progress (Cusicanqui, 2014; Gudynas 2017). While Morales claims Sumaq Qamaña as the path forward, participants in this study argued that in their communities, "that thing, Sumaq Qamaña, does not exist here.” Moreover, participants like Doña Laura, 52, made it clear that Sumaq Qamaña and mining cannot co-exist:

Sumaq Qamaña means good food, good nutrition, that the soil is healthy, that the lands are not contaminated, that our animals have grass to eat and that we have water to drink, that is Sumaq Qamaña for us...mining [contamination] burns Pachamama, it burns the grass, pollutes or water so with contamination it is impossible to have Sumaq Qamaña.

As part of Wasi Pacha's workshops on ancestral knowledge and food sovereignty, we 
traveled to Peñas, a community two hours outside the city of Oruro that has a peculiar relevance. Peñas contains the ruins of the Anahuani barracks were Mallku [leader] Juan Lero trained hundreds if not thousands of indigenous people during the revolution of 1899, and alongside Pablo Zarate Willka (a legendary indigenous leader) led one of the largest indigenous uprisings in the history of Bolivia. During this time, Juan Lero was proclaimed the first indigenous president of Bolivia. This history is ignored, maybe because it challenges Evo Morales' claim as the first indigenous president. The official narrative is that Juan Lero self-proclaimed himself as first indigenous president. However, the participants and the people I spoke with doubted this.

Peñas is also peculiar since it represents all that which is impossible to imagine about el Altiplano. Many people assumed that el Altiplano and its natural desert-like geography makes indigenous campesinx ways of life unbearable, which might be partially true. For example, Don Rodolfo, 56, the water coordinator for the Machacamarca municipality, expressed: "The problem in el Altiplano is that this is not a region like Santa Cruz, where you can have extensive soy fields. Here the climate is very special, and a small frost can destroy everything, and that's why the region depends on mining." Elsewhere I described the state's ongoing bias against agrarian economies that has manufactured this perception of el Altiplano as sterile and harsh, deeming the eventual decline of indigenous campesinx communities inevitable. Yet the community of Peñas challenged this imaginary, and the key for Peñas is clean water, since it has not experienced mining contamination yet (although there were recent allegations of possible mining concessions nearby). Peñas obtained a government project to create greenhouses 
and open cultivation of organic crops. The greenhouses produce cabbage, bell peppers, tomatoes, zucchini, cotton, cucumbers, spinach, and yucca, while the open cultivation of crops includes apples, peaches, flowers for commercial sale. These crops are not supposed to grow in el Altiplano. When I told my family and friends about Peñas, they were surprised: "I though el Altiplano was barren," commented my cousin. The quinoa boom described in Chapter Four has also favored Peñas, although Peñas is not a traditionally quinoa growing community. Many of its people are now growing quinoa, but not just any quinoa. Don Felix, an agro-ecologist who is from and lives in Peñas, and other people from his community created AIOP (Integral Association for the Organic Production in Peñas), one of the few agro-ecological centers in Bolivia that produces organic quinoa. Most importantly, Peñas is a community that has not suffered any impact of mining contamination. This means the community has access to clean water, which has made all of these projects possible. The importance of water is reflected on Peñas' most important annual festival: el ritual de cambio de agua [the ritual for exchange of waters], a two-day celebration of life around water where people traveled to the surrounding mountains to offer tributes (in the form of beverages and amulets) to the headwaters.

Don Alex has been a key actor in the realization of these projects. He, like many of the leaders I met, had a simple and humble way of being, yet his wisdom and knowledge attracted full attention to his words. He grew up in Peñas and has a degree in agronomy, therefore he knows extensively the local and socio-agricultural context of this place, from the history of the andenes, or agricultural terraces that the Incas used to grow 
crops, to its ecosystems and the micro-climates found in Peñas, to local legends like the lari lari, a mythical being similar to a giant fox, but with crow's wings and whatever else the story teller wants to add. One early morning during the workshop I participated in with, we walked to the top of a nearby mountain to receive its healing energies and to welcome the sunrise. Mountains have a socio-cultural importance in the Andes since they represent ancient spirits and according to the people; mountains trap and release good energies that one must honor. This mountain is also special to Peñas because it has its main headwater's on it. During our walk to the top of the mountain, Don Alex explained that there were many types of local grasses and plants: Muña, Añahuaña, Sachacoma, Cipres Ayahuaneños, Quiswiña, Queña, and Suico, among others, most of which are used for medicinal purposes. On our way back, Doña Martha, a comunarix from Peñas, cooked pisara [toasted quinoa] with cheese and then for desert she made mulu mulu (quinoa with sugar and pito [quinoa flour]). Figure 19 shows the crops growing in the community of Peñas with open cultivation, and also crops such as cucumbers growing within greenhouses. The picture on the bottom left shows a river going through Peñas.

While having breakfast, Doña Martha explained the process of cultivating quinoa, how it is connected to the moon's cycles and how life and nature are relational, meaning that whatever we do, and how we do it has an impact on our surroundings: "I learned that from the sheep," she said. I did not ask what she meant because I kept thinking about that idea. Don Alex then agreed with Doña Martha, explaining that "this principle is reflected in Huayanca, to give to your neighbor the best seeds because if they do good, you will also do good," referring to both seeds and people. 
Around eleven participants from the city of Oruro, Cochabamba and La Paz participated in this trip. Before the last day of this workshop, we had a debrief session the day before we went to the sacred mountain. We ate pisara and drank tea of wira wira (a local herb). It was strange and stunning to hear that everyone in the group had a story connecting these local foods to childhood memories. Wira wira reminded me of how my mom used to use this plant to cure the cold and the flu when I was a child. We realized that it was many years since we had eaten these foods, and therefore many years that we had not talked about how our grandparents cultivated these plants or how our grandmothers and mothers cooked them. Carlos, an anthropologist student mentioned that "this was an awakening of our consciousness and it reminded us to the moments with our grandparents." We realized we were very disconnected from our ancestors, from our roots and from these local practices. Doña Raquel, a member of the Bolivia Free of Transgenics collective, linked these reflections to a presentation she made about agribusiness in Bolivia. She stated:

The agribusiness sector is based on exploitation and the monopoly of power, where campesinos agricultores [agricultural peasants] like Don Alex are excluded and with them our rich tradition of indigenous knowledges and foods, and also the connections among us, between us, between generations and between our surroundings and us. 

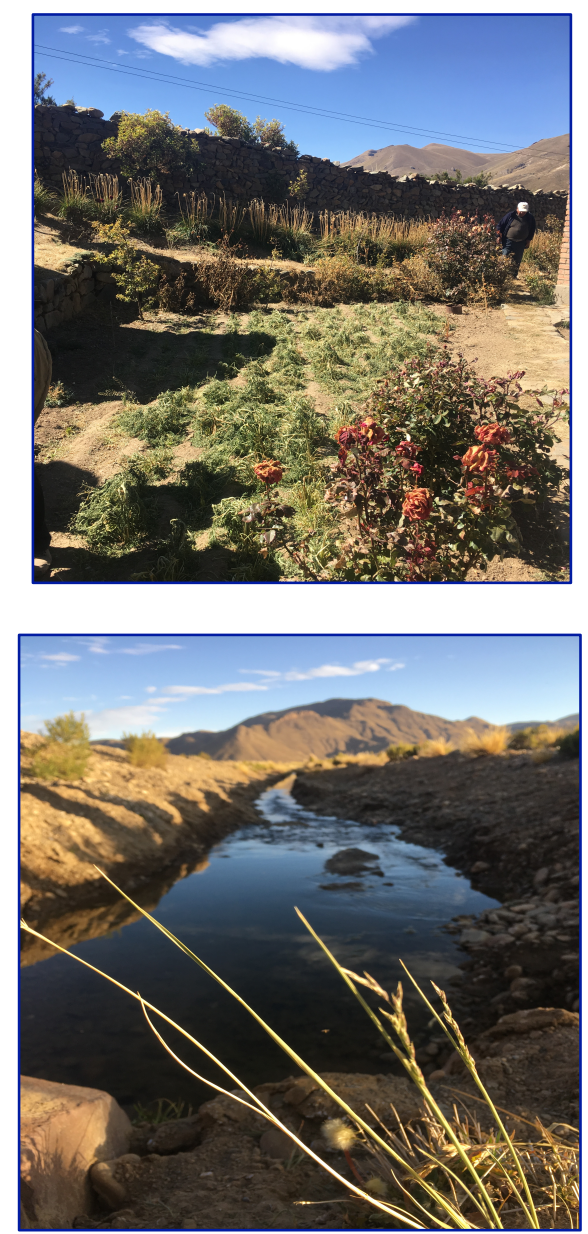
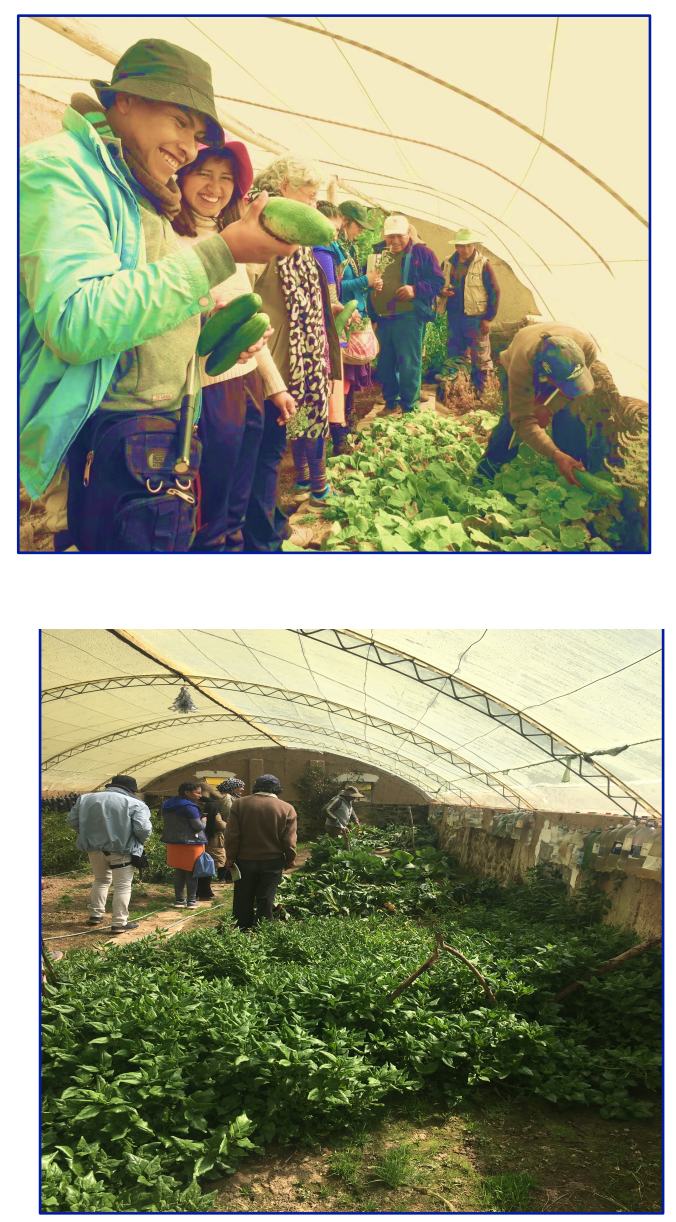

Figure 19. The community of Peñas, Oruro. Potograph by the author.

We also reflected on the notion that life is relational, and that we and everything around us, plants, animals, mountains, are interconnected, from the production of the quinoa on our plates to macro-relations between the state, the agro-business sector and us as members of society. Blanca, a tourism student who came with us, stated: “This trip made me realize that another reality is possible." The trip from Peñas back to Oruro was two hours and a half by minibus, therefore I had some time to take a nap, and to observe the landscape. I saw Peñas' cemetery, and it reminded me of a comment that Dona Patricia, 43, from Puñaka Poopó made during a conversation we had: "Those [non- 
contaminated] communities even have cemeteries...if people die there, [it means] they also live there." During the trip back, Tania from Wasi Pacha mentioned the following: Sumaq Qamaña is not just going back to the countryside. Many people think that Sumaq Qamaña means that indigenous people continue wearing traditional clothes and continue living in mud brick houses, and I disagree; living well is to have autonomy over your territory without affecting others.

I kept thinking about what Blanca mentioned, that another reality is possible. How strange that amidst the power imbalances of these situations, a reality where communal relationship based on Ayni (reciprocity), Huayanca (seeking the wellbeing of others as one's own) and Sumaq Qamaña, even when ignored and purposely repressed, are still vibrant and ever-present in these indigenous peasant communities. This to me, is everyday resistance.

\subsection{Summary}

While Chapters Four and Five describde the many difficulties and barriers that indigenous campesinx women and their communities face as a result of mining contamination, this chapter examined women's narratives and their praxis of resistance. Chacha-warmi, the indigenous concept of duality and complementarity, has maintained and created important although still unequal spaces for women to become leaders. Whereas CORIDUP represented a moment of significant mass organizing efforts against mining contamination, women continue everyday resistances in their daily lives and through their leadership positions. Women described how the intersection of their daily life experience with contamination, combined with knowledge from their community 
leadership experience, has sustained their resistances and propelled them to challenge authority. In their narratives, women described how their resistance has shaped, and is in turn guided by, their sense of what is right and wrong — la conciencia—consciousness and a deep commitment with their communities, which has motivated women to take actions against those in power.

Furthermore, often ignored or taken for granted is the constant creation by women of solidarity networks that strengthen relationships within and between communities that become central in maintaining their social fabric. This is a fundamental role in the labor of community reproduction and resistance that is often invisible or taken for granted.

Finally, Chapter Six examined the notion of indigeneity and revealed it as a fluid concept which participants use as a bridge to connect different people to their causes. It is a discourse of identity and values used to build solidarity beyond the community.

The experiences of Wasi Pacha and Las Ramonas collectives show how participants challenge the urban-rural divide to support anti-mining struggles by creating connections through an appeal to indigeneity, campesinx interests and identity. Finally, Chapter Six ends in an examination of the community of Peñas that shows how local communities are constantly creating alternatives. Peñas is a microcosm of a different reality where indigenous campesinx are able to thrive and this reality is possible by having access to clean water. Peñas showed that water is life. 


\section{PART III}

CHAPTER SEVEN. ANALYSIS AND DISCUSSION

CONCLUSIONS 


\section{CHAPTER SEVEN}

\section{ANALYSIS AND DISCUSSION}

The election of Evo Morales as the first indigenous president of Bolivia was part of the Pink Tide, a regional political shift towards progressive socialist governments in Latin America (Sankey \& Munck, 2016). President Morales's election was a product of radical social movements against neoliberalism, which demanded water as a common good and not as a commodity. Morales came to power with a solid rhetoric against colonialism and capitalism. Nevertheless, in practice, the Morales government is promoting a form of development reduced to economic growth, progress, and modernity. To fulfill its promises to implement progressive policies while simultaneously conforming to western-style modernization, Morales re-instated an extractivist model of development know as neo-extractivism. Nevertheless, critics have demonstrated that although neo-extractivism generates rents that the state uses for progressive programs, it still benefits the private sector; it still continues the colonial division of labor and its destructive socio-environmental effects are unchanged (Svampa, 2012).

While the political economy of neo-extractivism and the state's contradictions have been previously studied, an analysis of how such macro relations have affected the lives of people, particularly indigenous women, is lacking. This is important because as other authors have argued, a look at the lives of indigenous women has the potential to show the ways in which capitalism intrinsically expands beyond economic relations to heavily produce and simultaneously be co-produced by racist and patriarchal hierarchies (Rivera Cusicanqui, 2012; Mohanty, 2003). Using a multi-theoretical framework 
explaining micro and macro processes, this dissertation offers a close examination of the narratives, knowledge and praxis of indigenous campesinx women in Oruro, Bolivia to show how extractive capitalism relies upon extra-economic processes for accumulation by dispossession $(\mathrm{AbD})$ to happen. It also examines the everyday practices of cooperation, reciprocity and resistance of indigenous campesinx women to show that the rebellious potential of indigenous communities is reproduced in these subjugated spaces that represent both a threat to and an alternative to the hegemonic necessities of capitalism.

To elaborate on this analysis, I first start with a review of the literature on the political economy of neo-extractivism and then I present a summary of the key findings of Part II. I then return to the theoretical ideas and the framework presented in Chapter Two to interpret the findings of this study. ${ }^{88}$ This dialectical interpretation of data in light of the theory and theory in light of the data aims at moving from descriptions to understandings of the findings. In doing so, this analysis offers the following key arguments:

1. On the question of how neo-extractivism affects the lives of indigenous women and in line with the literature review, this study shows that neo-extractivism continues the same detrimental socio-environmental effects as classical extractivism. To focus on the racialized and gendered aspects of it, I use Harvey's concept of Accumulation by Dispossession (AbD) and Bhattacharya's Social Reproduction Theory (SRT) to argue that extractive capitalism depends not only on the dispossession of indigenous lands that

\footnotetext{
${ }^{88}$ In this Chapter, I only summarize or refer to parts or concepts of my theoretical framework that are crucial in describing these findings. For a more comprehensive review of the theoretical framework for this dissertation, please see chapter two.
} 
are in its immediate surroundings (points of production) but also on distant indigenous territories that are often ignored within the spatial scope of extractive capitalism. Such indirect dispossessions, produced by mining contamination of waters and soils, also lead to the semi-proletarianization of indigenous people through the deterioration of subsistence agriculture, creating a rural diaspora to urban centers and the impossibility of a return. Nevertheless, often semi-proletarianization does not lead to waged labor, but rather leads indigenous and rural migrants to become surplus or disposable population. In light of Social Reproduction Theory (SRT), which brings a gendered and intersectional light to $\mathrm{AbD}$, we can see how mining contamination of waters, which is at the epicenter of all these issues, makes the social reproduction of indigenous campesinxs ways of life, where women play a central role in both productive and reproductive activities, extremely difficult, if not impossible.

2. On the question of how the state shapes relations between neo-extractivism and indigenous campesinx women, I use Mamdani's theory of political identities to argue that in order to enthrone its hegemony, the Bolivian state is strategically manipulating indigeneity to craft a national identity. This new notion of the nation as indigenous is broad and inclusive, incorporating cultural and ethnic identities that were previously marginalized from citizenship rights. At the same time, however, the state-crafted indigeneity purposefully conflates cultural groups with political ones. One example presented in this study is the tensions between indigenous miners and indigenous campesinxs, where the former is the political base of the Bolivian state. This situation creates and exacerbates tensions between groups, which strengthens the role of state as 
the chief decision maker regarding indigenous rights and natural resources. Paradoxically, this state-led politicization of ethnic inclusion also leads to class exclusions perpetrated by the same state, particularly of groups such as indigenous campesinx communities in the Andes that the state perceives as being of little economic and political benefit to its developmentalist interests.

Through the lens of Mamdani's theory of ethnicity as a political identity, this study reveals that in order to tame dissent and political unrest, the Bolivian state uses a legal framework based on pro-indigenous and pro-environmental grandiloquence as a cover for arrangements that award the mining sector unequal privileges and rights. The Bolivian state also uses a divide-and-conquer strategy within and between cultural and political groups as well as an increased bureaucratization of daily life and organizing efforts. This is not just a coincidental alignment of economic interests between extractive capitalism and the state, I would argue, but rather there is also an ideological and political interest of the Bolivian state to transform Bolivian citizens into modern, market-based consumers.

3. For the final question, on how indigenous women organize to challenge the impact of state-led extractivism on their lives and their communities, I use SRT to recenter attention on social reproductive activities where indigenous campesinxs women play a central role. Here I argue that it is in this sphere where resistance happens in the everyday of life and where the potential formation of unsubordinated actors is located. The daily responsibilities of social reproduction, within the context of subsistence agriculture where indigenous campesinx women play a central role as producers and 
social reproducers, are embedded in Andean epistemes of reciprocity, duality and complementarity, expressed in practices like Ayni. The combination of these three forces (subsistence production, social reproduction and culture) has allowed women to build solidarity networks that keep the social fabric within and between communities alive. These solidarity networks also provide important socio-political resources and sites for community-based resistance. Besides, the vivid experience of contamination, combined with knowledge acquired from leadership positions, has allowed indigenous women leaders to exercise their agency through unsubordinated practices that defy authoritarian figures and unequal power relations.

Moreover, while the Bolivian state politicizes indigeneity to consolidate power, community-led efforts such as CORIDUP politicize indigeneity seeking justice. Rather than an extraordinary event, CORIDUP and the individual efforts of indigenous women to challenge unequal powers should be understood as part of an ongoing history of resistances that has been taking place in the Andes for centuries, where the political actor has been galvanized around her indigenous identity. The socio-historical context - time and class struggle — conditions how and when this galvanization happens. Nevertheless, seemingly small uprisings such as CORIDUP should be located within a broader historical context. These two distinct approaches to indigeneity, one from the state and one from communities, show the complexity of indigeneity as a category for empirical and analytical purposes.

Furthermore, unlike the Bolivian state that uses indigeneity as this inclusive but rigid identity, indigenous communities, particularly women, use indigeneity as a fluid and 
dual concept, one that seeks to be connected and reconnected to territories and is also independent from them. This indigeneity is rooted on territories, and also in the praxis of what it means to be indigenous in this specific socio-historical moment. Such fluid indigeneity has allowed indigenous communities and particularly women to challenge imposed divisions led by the state and has allowed them to build alliances across ethnic, gender and geographical locations to organize against extractive capitalism. These efforts, apparently small, represent genuine threats to the logic of capitalism and also represent an alternative to capitalist, neo-colonial and patriarchal mandates. In what follows, I offer a detailed analysis of these arguments.

\section{The political economy of neo-extractivism}

According to sociologist and Bolivian vice president Alvaro Garcia Linera, the tensions and contradictions of the Bolivian state and its cozy relationship with the extractivist sector must be understood as creative tensions, where competing projects, one capitalist and the other one communal, if properly managed by the state, can help the course of revolutionary processes (Garcia Linera, 2013; Webber, 2017). As Garcia Linera argues, the state is a central player in the revolutionary process. Looking specifically at the case of Bolivia, and to summarize the chapter on these tensions from a theoretical perspective, in this study I offer a different perspective based on Block's theory of the structural mechanisms of the capitalist state (1987) and Wallerstein's world systems theory (1974). Block's theory shows that the structural mechanisms that make

the state dependent on capital, such as business confidence, force the state to lean towards capitalists' interests. At the same time, the state is also conditioned by the appearance 
of neutrality it must show to the working class in order to keep its own power (1987). In the Bolivian case, neo-extractivism does not support orthodox neoliberal policies, for example, natural gas and to a lesser extent mining are supposed to be public-led economic activities. Neo-extractivism also portrays the state as a neutral actor that best represents the interests of indigenous communities. In reality, however, the Bolivian state still operates in the interests of the capitalist class, making sure its own interests align with them and the short-term gains by neo-extractivism do not supersede its long-lasting socio-environmental effects.

Furthermore, seen from the vantage point of Wallerstein's world systems theory, that is, within a regional and global context of the colonial division of labor, neoextractivism maintains Bolivia's role as a peripheral country providing raw and primary resources to core countries. In this respect, neo-extractivism does not challenge, but rather operates within the logic of the colonial division of labor. Bolivia, therefore, remains a peripheral country dependent on foreign investment for the extraction and export of its natural resource wealth (Gudynas, 2011).

As argued elsewhere, while these tensions have been extensively explored, how such macro processes affect micro processes of everyday life, particularly from the vantage point of indigenous women, is often under-explored. Table 8 presents a summary of the key findings for this study and the following sections present a detailed theoretical analysis and discussion on such findings. 
Table 8. Key findings of this study

\begin{tabular}{|c|c|c|}
\hline Neo-Extractivism effects & The State and neo-extractivism & Women's resistance \\
\hline Migratory diasporas & Legal frameworks & Grass roots organizing \\
\hline $\begin{array}{l}\text { A diaspora to urban centers } \\
\text { that started around the } \\
\text { 1990s and has continued. } \\
\text { Although there are different } \\
\text { reasons for this migration, } \\
\text { participants concluded the } \\
\text { main cause is mining } \\
\text { contamination of waters } \\
\text { because it impedes } \\
\text { subsistence agricultural } \\
\text { practices }\end{array}$ & $\begin{array}{l}\text { A new legal framework shows a } \\
\text { progressive discourse and policies of } \\
\text { ethnic inclusion and environmental } \\
\text { protection. On the other hand, this } \\
\text { legal framework continues old, and } \\
\text { creates new inequalities that favor the } \\
\text { mining sector. MML } 535 \text { for example } \\
\text { grants unlimited water access rights } \\
\text { to the mining sector while denying } \\
\text { the same rights to indigenous } \\
\text { communities. }\end{array}$ & $\begin{array}{l}\text { Women participated as } \\
\text { community leaders with } \\
\text { CORIDUP to achieve the approval } \\
\text { of SD 0335. Although CORIDUP } \\
\text { has ceased its momentum, it still } \\
\text { represents a moment of significant } \\
\text { grass root mobilizations from } \\
\text { which women have drawn } \\
\text { important organizing lessons }\end{array}$ \\
\hline No returns & Ethnic inclusions, class exclusions & Fluid indigeneity \\
\hline $\begin{array}{l}\text { The boom in the demand of } \\
\text { quinoa since } 2013 \text { created a } \\
\text { revitalization of rural } \\
\text { livehoods in Oruro. People } \\
\text { who left rural communities } \\
\text { went back to yield this } \\
\text { seed. The communities for } \\
\text { this study however, did not } \\
\text { experience such } \\
\text { revitalization because of } \\
\text { water and soils } \\
\text { contamination. }\end{array}$ & $\begin{array}{l}\text { Participants described a paradoxical } \\
\text { experience of ethnic inclusion, } \\
\text { described as feeling represented and } \\
\text { included as indigenous communities, } \\
\text { while at the same time being } \\
\text { excluded based on their class- } \\
\text { condition as campesinxs, especially } \\
\text { campesinxs against mining } \\
\text { contamination. }\end{array}$ & $\begin{array}{l}\text { While the state uses an inclusive } \\
\text { but rigid indigeneity, women and } \\
\text { indigenous communities use a } \\
\text { fluid and dual indigeneity that is } \\
\text { connected to territories and } \\
\text { independent from them. This fluid } \\
\text { indigeneity has allowed women } \\
\text { and communities to build alliances } \\
\text { across ethnic, gender and } \\
\text { geographical locations to organize } \\
\text { against extractive capitalism }\end{array}$ \\
\hline Water is life & Divide \& Conquer & Solidarity networks \\
\hline $\begin{array}{l}\text { According to participants, it } \\
\text { is through water that all } \\
\text { their struggles interconnect: } \\
\text { migration, lack of crops, } \\
\text { dying animals, sick people, } \\
\text { etc., and water is also the } \\
\text { epicenter of conflict } \\
\text { between these } \\
\text { communities, and the } \\
\text { Huanuni mine. }\end{array}$ & $\begin{array}{l}\text { To discipline communities and to } \\
\text { lessen criticisms of such } \\
\text { contradictions, the state relies on a } \\
\text { divide \& conquer strategy creating } \\
\text { and exacerbating hostile binaries of } \\
\text { miners-campesinxs, local authorities- } \\
\text { indigenous authorities, MASistas - } \\
\text { non MASistas, etc. In parallel to this } \\
\text { strategy the state has also increased } \\
\text { bureaucratization in all aspects of } \\
\text { life, particularly the organizing } \\
\text { efforts of communities to contest the } \\
\text { effects of mining contamination. }\end{array}$ & $\begin{array}{l}\text { This fluid indigeneity, and the } \\
\text { experiences of women as leaders, } \\
\text { combined with Andean epistemes } \\
\text { of reciprocity, solidarity and } \\
\text { complementarity have allowed } \\
\text { them to build solidarity networks } \\
\text { among them and within and } \\
\text { between communities. These } \\
\text { networks maintain the social } \\
\text { fabric of communities and become } \\
\text { potential sites of resistance. }\end{array}$ \\
\hline
\end{tabular}

\title{
7.1. Neo-extractivism and the agrarian question
}

\author{
At its very core, neo-extractivism continues the perpetual commodification of
}


nature and the ongoing dispossession of indigenous lands, and indigenous ways of life under processes of Accumulation by Dispossession (AbD). In this study, AbD has three dimensions: semi-proletarianization, land grabs, and the (lack of) social reproduction for indigenous campesinx communities. These three cases of $\mathrm{AbD}$ revolve around the agrarian question, about the fate of indigenous campesinxs communities that are dispossessed of their lands by mining contamination.

\subsubsection{Proletarianization interrupted}

Primitive accumulation and the violent alienation between labor and land are not the original sins of capitalism, as Marx argued, but rather, ongoing processes central in capital accumulation (Harvey 2003; Perrault, 2013). Harvey calls this ongoing process Accumulation by Dispossession (AbD), the strategy to support capitalist accumulation that relies on different mechanisms to create capital surplus, such as privatization, financialization, and state re-distribution to manage specific crises of over accumulation (Harvey, 2003; Perreault, 2013). Proletarianization, the process in which producers, small campesinx farmers, are separated from their lands, and means of production and are then transformed into wage laborers is a fundamental "phenomenological element of capital accumulation" (Perreault, 2013, p. 1052; Petras \& Veltmeyer, 2014). Proletarianization therefore points to the separation of labor from land, which usually refers exclusively to labor and productive forces but also includes appropriation of social relations, knowledge, and beliefs, among others (Harvey, 2003).

In Latin America, however, proletarianization takes a different shape from traditional Marxist theories since the only outcome is not an industrial proletariat, but 
also a semi-proletarianized "landless or near-landless rural worker" who must migrate to the cities in search of paid labour (Petras \& Veltmeyer, 2014, p. 39). Moreover, in the case of indigenous campesinx communities vis-a-vis extractive capital, this assumed proletarianization is not a linear process, but rather a more complicated and lethal dynamic of dispossessions. As Li (2010) demonstrates, when territories and their resources are profitable, but people are not, "dispossession is detached from any prospect of labour absorption" (p. 69). In the context of Latin America, various authors argue that neo-extractivism is a "resource curse". Because production is based on the commodification of nature (resources), not labor, there is little investment in the development of internal economies. As Burchardt and Dietz (2014) argue, because resource-based economies might produce over-value currencies " the domestic industrial and service sectors [become] less competitive and imported industrial goods cheaper" (476). What this means is that the extrativist-based development program in Bolivia displace people without creating formal work for them.

The stories presented in this study represent clear examples of uneven dispossessions that lead to rural diasporas to urban centers, which might or might not lead to either proletarianization or semi-proletarianization. The majority of migrants for this study (residentes) work in the informal sector as street vendors and some still engage in some form of subsistence agriculture. Nevertheless, the vast majority does not engage and is unlikely to engage in waged labor. There are some indigenous campesinxs that do work as miners, usually itinerantly: they go back and forth from campesinxs to miners. However, the majority works as peones, informal workers with no benefits and to formal 
contracts.

While the causes of such rural-urban migratory patterns are complex, multilayered and not exclusive to these communities, participants concluded that mining contamination is the main cause for their expulsions and territorial dispossessions, therefore forcing them to migrate to the cities where they are not guaranteed to become surplus labour necessarily for accumulation. Bolivia is not industrialized, nor has it diversified its economy. To the contrary, under Evo Morales, the development strategy has relied primarily on the re-primarization of the economy through neo-extractivism, which does not rely primarily on labour exploitation (Svampa, 2015). Furthermore, in the context of the Bolivian Altiplano, AbD does not aim to fix a crisis of over accumulation, and lands are not expropriated for investment capital to take advantage of it (Perreault, 2013). However, this passive and covert, yet still violent dispossession of lands and livehoods is necessary for extractive capitalism to function since its spatial reach (particularly through water flows) demands such dispossessions (2013). Economists would call this an externality. Nevertheless, this is misleading since this process is part of a central (although not directly profitable) mechanism for neo-extractivism to function. In other words, not all dispossessions are directly connected to the need for accumulation, although they are part of it.

Furthermore, the contamination of soils and waters is in effect the dispossession of their right to return. As mentioned in the findings chapter, these communities were traditionally quinoa farmers. While the 2013 boom in quinoa demand created a revitalization of rural livehoods around Oruro, contaminated communities were unable to 
return and benefit from this boom precisely because their lands were contaminated. As participants argued, their lands have been (indirectly) expropriated to become the tailing dam of the nationalized Huanuni mine. The quinoa boom is just one example to show that contamination makes any attempt at revitalization nearly impossible.

\subsubsection{Concealed land grabs}

Land grabbing, or the large scale acquisitions of lands by national or transnational companies and governments, is explained as a global phenomenon connected to the 2007-2008 food price crisis and dynamics within food regimes that has received significant attention, usually within the context of weak states in Africa (Borras, Kay, Gomez \& Wilkinson, 2012). Defining what land grab, however, is a complex and ongoing process. The FAO (Food and Agriculture Organization) for example, defines land grab in relation to scale, where a thousand or more hectares taken by multinationals are considered a land grab (2012). Nevertheless, the focus on large-scale acquisitions and activities, what Edelman calls "fetishization of the hectare", risk ignoring other important land transformations that do not fit neatly in such strict categories (Hall, 2013). Hausermann and Ferring (2018) provide a sounder definition of land grabs as the transnational agreements initiated by foreign individuals, governments or corporations "to produce natural resource commodities such as food, biofuel, and minerals" (p. 1012). To elaborate on this concept, Borras, Kay, Gomez \& Wilkinson define land grabs as representing three key features: first, control, as the power to control land and its resources to obtain an economic benefit from it; second, scale, not just in relation to land acquisitions but also the scale of capital involvement; and third, land grab as 
happening strictly within the need for capital accumulation to respond to food, energy fuel, and climate crisis (2012, p. 404).

While rigorous conceptualizations do offer important clarifications of what land grab means, especially in relation to $\mathrm{AbD}$, they also understate important aspects of it. Hall (2013), for example, problematizes the previous conceptualization even further. In the context of Africa, viewing land grabs in term of strict crisis of financial markets and other crisis risks ignoring the complicit role of local actors and domestic states (2013). For extractive capitalism, mining-induced displacement and resettlement (MIDR) is often mentioned as the principal way that large-scale mining (often open pit mines) dispossesses indigenous communities of their territories (Jenkins, 2014). This occurs in what Owen and Kemp calls co-habitation, where communities remain in close proximity to sites of production (2015) Nevertheless, such a narrowed view of land grabs as direct and overt dispossession near production sites (in this case near mines) ignores the spatial and often invisible scope of extractivism and its footprint (Perreault, 2013).

There is the need, therefore, to expand the meaning of land grabs to apply this concept to a context of extractive capitalism and ongoing mining contamination prior the 2007-2008 crisis and highlight the political and forceful aspect that "grab" implies (Hall, 2013). What participants in this study established in their experiences with mining contamination is that neo-extractivism depends on these indirect and covert forms of land grabs. Although land grabs in this context is undefined and vague, and only partially fits under existing land grab conceptualizations, the result is still the same: it produces the dispossessions of vast amounts of lands. This covert form of land grabs also produces the 
dispossession of indigenous campesinxs from their lands. Meanwhile, the role of the Bolivian state in enabling such dispossessions is also concealed. In this particular case, the state plays an important role as an enabler of such dispossessions by creating a legal framework that favors the rights of the extractivist sector. Supreme Decree 0335 (SD 0335) and the Mining and Metalurgic Law 535 (MML 535) exemplify these imbalances over rights. The state also plays an enabler role by pretending neutrality and being absent in the conflict between contaminated communities and the nationalized Huanuni mine. This is why a definition that focuses on overt land grabs connected to large-scale land acquisitions or those connected to direct production sites might underestimate the spatial extent to which extractive capitalism relies on these covert forms of AbD. This fixation on production sites that makes these dispossessions invisible has also another invisible dimension that is central for $\mathrm{AbD}$ processes: the dimension of social reproduction.

\subsubsection{Un-reproducing the other}

My first impression when I arrived to the Kochi Piacala community was that there was nothing to observe, no children, no central plaza, no community life. And it is precisely this lack of social life, this nothingness to witness that became everything to witness about the subtle ways that extractive capitalism relies upon neo-colonial and patriarchal orders. Studies about capitalism tend to create a fictitious separation between production and reproduction processes, usually ignoring how both spheres are theoretically and operationally united (Bhattacharya, 2017). In the case of mineral extraction, attention is given to production processes and production sites, such as women working within mining industries, or the gendered effects of mines in co-habitational 
communities that are in close proximity to mining centers (Lahiri Dutt, 2011). On the other hand, SRT asserts that the capitalist system is not just about workers and owners, but rather it is about the social reproduction processes that create and maintain the worker outside production, but what does social reproduction mean?

As a concept, social reproduction refers to the beliefs, attitudes, activities, behaviors, emotions and relationships that are necessary to maintain everyday life (Bhattacharya, 2017). In other words, social reproduction is a multiplicity of activities to provide food, clothes, and shelter for the worker, as well as the socialization of children and care for the elders (2017). As a theory, SRT argues that capitalist development depends on both market and non-market relationships, and it does not only point to their differences but rather SRT shows how they are interdependent. SRT also argues that oppressions are structurally linked to capitalism. In other words, oppressions are not byproducts, but rather they are part of capitalism's wheels. Third, SRT shows the dual capacity and potential of labor to produce labor power, and also to reproduce society in its entirety (2017). But which labor power and for what purposes? This is a relevant question because extractive capitalism is not labor intensive; it is resource intensive. Surplus value does not come from the exploitation of labor (although it still needs workers-minersto operate) but principally from the exploitation of resources.

In the context of the Andes where industrialization is not taking place, social reproductive activities such as cooking, grazing animals, and washing clothes do not create labor power for extractive capitalism. As Li argues, when capital needs land but not labor, such as in the case of extractive capitalism, "the existing occupants of the land usually get 
expelled" (2011, quoted from Borras, Kay, Gomez, \& Wilkinson, 2012, p. 412). This represents an interconnected but inverted link between production and social reproduction. Extractive capitalism creates and depends on the absence of the social reproduction of indigenous campesinx communities. It is no coincidence that participants decisively concluded that mining contamination, particularly of waters, halt's all their productive and social reproductive activities and this, they argued, is the main reason forcing them to leave. Although the natural environment of the semi-arid regions of el Altiplano does not make indigenous campesinxs' lives easier, their expulsions and their diaspora are a consequence not of this harsh environment but of economic and political processes connected to capitalist development and the ongoing bias of the state (before and also during the MAS government) against agrarian economies (Webber, 2017).

The impossibility of social reproduction within contaminated communities also has political implications. When people leave, then who is left to complain?, asked Don Luis, 43, from CEPA, rhetorically. While communities make strenuous efforts to confront the Huanuni mine, demanding better environmental regulations, the unending fracture of communities that the double residency and migratory diasporas create, takes away their collective power to organize and resist against the extractivist sector and against the state. Nevertheless, like a stubborn compass always pointing north, these communities, regardless of all the political and economic constraints, have organized through CORIDUP and they have had a significant participation of indigenous campesinx women.

About women and anti-mining resistance, it is said that much attention is devoted 
to explain the "why" of women's participation in these struggles, while little is known about the "how" (Deonandan \& Dougherty, 2016). Simply put, women resist because mining destroys their communities. Moving on. I argue, however, that the "why" of this question is taken for granted and this represents a serious academic blind spot. Capitalism develops on specific historical and socio-political contexts, and it depends on specific axes of race, class and gender dominations (Bhattacharya, 2017; Hill Collins, 2000). As Eisentein rightfully argues, studies within political economy often present labor as if it has no body "no home that actually creates it... It remains abstract and therefore colorless as in white, and sexless as in male" $(2014$, n.p). Therefore, to truly unearth how capitalism depends on racialized and gendered processes that benefit accumulation, and why women organize against these processes, we must explore even those redundant and mundane questions about its operations. To elucidate this, I offer an analysis of water as the epicenter of multiple connections related to power, oppression, and $\mathrm{AbD}$ to show that neo-extractivism relies on racist, colonial, and patriarchal hierarchies that continue the oppression of indigenous campesinx women.

\subsection{Water is social life}

The radical social movements that consolidated Bolivia into an anti-neoliberal vortex at the beginning of the $21^{\text {st }}$ century were galvanized around the water wars against the American transnational corporation Betchel and the French water giant Suez. The notion of water as a common good and not as a commodity placed these movements in direct opposition to neoliberals' premises of privatization and commodification (Spronk, 2006). The premise of the social movements was that water is life - literally a matter 
of survival. As participants in this study demonstrated in their narratives, water is also social life; that is, water is central in the social reproduction of our communities and societies and its qualities depend on who controls it. Water therefore is not just a naturegiven good that brings life to communities, it is social and political, and as such, its character and effects depends on the power relations behind it. To understand the political character of water, one must connect it to its historical and economic trends (Ahlers \& Zwarteveen, 2009). We must seek therefore, "to politicize understandings of the distribution of water" because "water and social power are ... mutually constitutive" (Loftus 2009, as quoted in Jafee \& Case, 2018, p. 3).

Examining hydrosocial relations in the Andes, Perreault argues that $\mathrm{AbD}$ and the collective rights and access to water are too narrowly framed within processes of the market and privatization (2013). He brings attention to water's dispossession outside privatization by examining hydrosocial relations in el Altiplano and finds three separate forms of accumulations: accumulation of a) toxic sediments; b) water and water rights by the extractivist mining sector; and c) accumulation of landfills (2013). Similarly, this study brings light to the dispossession of waters outside of privatization and outside of urban towns. In this case study, dispossession happens through the expropriation of water from processes essential to the reproduction of indigenous ways of life.

The concept of waterscape, which recognizes how social and natural environments are co-constitutive of each other, is useful to understand relations around water in the Bolivian Altiplano. Waterscape helps to explore "the ways in which flows of water, power and capital converge to produce uneven socio-ecological arrangements over 
space and time" (Budds and Hinojosa, 2012, quoted in Joy, Kulkarni, Roth \& Zwarteveen, 2014, p. 114). Hydrosocial relations in the Bolivian Altiplano are deeply conditioned by mineral extraction, which produces a co-dependent and antagonistic relationship between indigenous campesinx communities and mining companies. It is codependent because both economic activities are water-centered, they both depend on water for their activities. It is Antagonistic because one must extract the rights of access to water from the other in order to maintain its operations. In the Andes, and exemplified in Mining and Metallurgic Law 535 (MML 535), the Bolivian state grants rights and access to water to the mining sector while simultaneously stripping these rights from indigenous campesinx communities. This creates an uneven socio-ecological relation, where water is deeply politicized and transformed. The potential of water for creating or destroying (social) life and for exacerbating inequalities, depends therefore on who has power over it. When the Huanuni mine controls hydrosocial relations, water becomes contaminated and brings dispossession of lands and ways of life. This also creates an uneven demand for and distribution of water since the Huanuni mine consumes around 28 million liters of water per day (Perreault, 2013). When indigenous campesinx communities control this hydrosocial relation, water creates the conditions to grow crops, to feed animals and to reproduce indigenous campesinx ways of life, which do not demand high consumption of water. This does not mean that indigenous communities are intrinsically guardians of nature and water; this means that their socio-ecological and material position allows for a different type of hydrosocial relation (later in this Chapter I will describe how Andean culture has also an effect on these relationships). In this 
manner, hydrosocial relationships within processes of $\mathrm{AbD}$ and in a context of extractive capitalism are racialized, making the indigenous campesinxs ways of life unproductive and redundant.

\subsubsection{The Andes and the matrix of domination}

Water and waterscapes also reveal the gendered and patriarchal features of extractive capitalism. It might seem obvious that water is central to all the domestic activities that reproduce life, such as washing clothes, cooking, as well as central in childbirth, raising children, and taking care of the elderly. Yet, this taken-for-granted approach obscures the central role women have in these water-centric activities and how mining contamination has a direct effect on their lives. The sexual division of labor is based on the biological distinction between male and female to create a sexed and gendered hierarchy where roles, activities and labor are "determined sexually... [it is the] basic mechanism of control for patriarchal culture" (Eisenstein, 1999, p. 202). Within this hierarchy the determining relations are those of reproduction, not production. And although sexual roles are institutionalized within the family, these roles are not limited to this (1999).

Indigenous campesinx communities in the Bolivian Andes are not exempted from the sexual division of labor. Although their cultural philosophies support egalitarian notions of gender-balanced participation (such as chacha-warmi) the socio-political organization within communities still rely on patriarchal hierarchies; that is, they are constructed on systems of male supremacy and superiority where power is distributed 
based on such assumptions (Einsentein, 1999). ${ }^{89}$ It should not be surprising then that indigenous campesinx women are the main caretakers within social reproductive activities; they are the ones who must find clean water, they must travel longer distances looking for it, they must nickel and dime their limited money for transportation and the cost of buying drinking water, and they must figure out how to save the little water they have to cook, to wash dishes, to feed their children and their families.

Indigenous campesinxs women are also producers; they are in charge of subsistence activities related to grazing animals and growing crops. They must make sure that their animals do not drink too much contaminated water in order to avoid being sick or they must make sure to take their animals to places where water is not too contaminated. This is why Doña Paula's main activity after cooking is to walk hours with her livestock looking for cleaner sources of water around and outside her community. If their lands are able to produce crops, such as in the case of Alantañita, women as producers must make sure to carry or find enough water to grow and care for these crops. Within the development of extractive capitalism, indigenous campesinx women are affected by their dual role in productive and reproductive processes. Their class as campesinxs, their ethnicity as indigenous and their gender as women place them in a tripartite axe of oppressions in what Hill Collins calls the matrix of domination (2000).

\footnotetext{
${ }^{89}$ Further analysis needs to explore and debunk the assumption that patriarchal hierarchies did not exist within indigenous communities in the Andes and that they arrived with colonialism. One of the records of Wamam Poma, a Quechua nobleman and chronicler during the $16^{\text {th }}$ century, depicts how indigenous male leaders encountered the Spanish conquistadors and offered them indigenous women as gifts (Galindo, 2014). At the same time, it is also important to clarify that colonialism exacerbated these patriarchal hierarchies. In the Andes for example, indigenous women played important roles outside the family as tejedoras (weavers), adivinadoras (diviners), merchants, etc., roles what were erased from Andean societies during colonialism and afterwards (Cusicanqui \& Geidel, 2010). An important starting point for this analysis should be Silverblatt (1990) and her examination of patriarchal relations before colonial rule in her book Luna, Sol y Brujas: Genero y clases en los Andes prehispanicos y coloniales.
} 
The orthodox neoliberal policies of the ' 80 s forced many Bolivian women, including the ones in this study, to migrate to the cities and to other countries, and it forced them to become what mujeres creando calls the exiles of neoliberalism. The women in this study are also the exiles of extractive capitalism. When they migrate to the cities, indigenous campesinx women continue experiencing these same oppressions. They are also discriminated against based on their conditions of being indigenous women and rural immigrants in the city.

Therefore, while neo-extractivism might seem a-racial and a-gender, indigenous campesinx women are the hardest hit by the corrosion of the socio-environmental conditions in their communities. This shows that extractive capitalism is not just about production, exploitation and the commodification of nature. It is also about oppression, reproduction, or the lack of it, as well as the continuity and exacerbation of colonial and patriarchal orders that have historically placed indigenous campesinx women at the bottom. As Mohanty argues, it is on their lives and their stories "that global capitalism writes its script" (2003, p. 514).

While the symbolic and dubious connection between Pachamama and womanhood might create well-intended narratives (Lahiri Dutt, 2011), especially among activist groups, this simultaneously ignore the socio-political and economic realities that expel women and their communities from their territories. Here I presented an analysis based on SRT to show how those material conditions, combined with historical and political processes of capitalist development related to colonial and patriarchal orders continue to disproportionally affect the lives of indigenous campesinx women. 


\section{3. Different face, similar neoliberal effects}

There are important ruptures between Morales and previous governments that should not be oversimplified or ignored. Unlike previous regimes, the MAS government has redistributed the resource rents and taxes received from the extractivist sector to lift many Bolivians out of poverty. This has also resulted in a growing and vibrant indigenous middle class that is proud of its ethnic origins and new class positions. In the past, social mobility among indigenous peoples in Bolivia often translated into their deindianization and their attempts to become more Europeanized by using western clothes for example. Nowadays, this emerging indigenous middle class displays its ethnic pride unapologetically through indigenous clothes, celebrations, and houses and buildings based on indigenous themes and architectures. Moreover, the MAS government and its wide-ranging approach of ethnic inclusion have translated into the highest participation of indigenous peoples and indigenous women in government and political affairs. In a context of deep-rooted racist structures and extreme social inequalities such as Bolivia, to go from receiving nothing to receiving something, even a tinglado or a cancha, represents significant improvements from past governments.

At the same time, however, there are significant continuities between orthodox neoliberal governments and the MAS government. At the regional level, like other Latin American countries, Bolivia too has bet on the consolidation of neo-extractivism as the new economic and political model of development. Svampa refers to this era as "the commodities consensus", where countries in this region, regardless of their political inclinations (leftist in Bolivia, right in Colombia, and centrist such as Peru), seek 
economic growth, productivity and modernity through the re-primarization of the economy (2012; Burchardt \& Dietz 2014). The commodities consensus therefore marks the beginning of a new economic and political era supported by the international demand of raw materials. Newer infrastructure projects like IIRSA (Initiative for the Integration of the Regional Infrastructure of South America), which facilitate the transportation of raw materials, show the consolidation of the commodities consensus as a long-term model, requiring further examination (Svampa, 2015).

The state plays a major role in the continuities of neoliberal practices(Harvey, 2005). While the Bolivian state claims to pretend to be neutral by distancing itself from orthodox neoliberal policies, it nevertheless continues to favor private and transnational interests (Webber, 2015; Gudynas, 2011). As Veltmeyer argues, what is happening in Latin America is a case of coincidental economic interests, where extractive capital receives profits and the state receives rents $(2012 ; 2013)$. In the case of Bolivia, rather than a proceso de cambio [process of change], reconstituted neoliberalism is a more accurate term that better describes the Bolivian state's current development model (Webber, 2011). It would be too narrow, however, to assume that the state's interests is just in rents. The state also needs political hegemony for its own sake. While the state's behavior is conditioned by the structural mechanisms mentioned elsewhere (Wallerstein, 1974), there is some leverage for independent political decisions detached from these limitations. To assume otherwise would be to simplify the state to a mere instrument of capitalist interests (Block, 1987). As Lenin remind argued, the state is always the expression of power relations in an historical context and is also contingent upon class 
struggles (Galindo, 2014; Block, 1987). In the case of Bolivia, the MAS government is seeking development a la Rostow's style (1960), that is, a linear economic growth into US-style consumerism and Eurocentric modernism. And in doing this, the state needs modern citizens who know how to replicate the logic of capital (Webber, 2017). Yet, this was a difficult task in a country whose indigenous majority has been historically racialized as the "backward other" of modernity and development. This was also a difficult task when this "other" claimed its revolutionary potential and created a political turmoil shaking the very pillars of the neoliberal state at the beginning of the $21^{\text {st }}$ century. The state therefore needed a gatopardismo: to change everything in order to change nothing.

In its quest for power and to appease this rebellious population, the Bolivian state made a neo-colonial turn with the reaffirmation of the colonial division of labor, perpetuating the role of Bolivia as a peripheral country (Webber, 2016; 2017). It is a neo-colonial turn also by shifting the pillars of state power upside down, where "the native... [sits] on the top of the political world designed by the settler" (Mandami, 2001, p. 658). In this project, the MAS government is using indigeneity strategically to craft a national identity where the Bolivian state has transformed itself into "the other" - that is -into an indigenist state which enthrones its hegemony as the main decision maker over indigenous rights and natural resources. The Bolivian state is doing this by conflating cultural identities with political ones, turning party affiliation into the measurement of true indigeneity. This transformation has led into incoherent compromises that are also antagonistic to the interests of the indigenous communities the state claims to represent. 
The following paragraphs analyze the Bolivian state's political project through the strategies of gatopardismo and inclusionary exclusions.

\subsubsection{El gatopardismo del MAS: to change everything in order to change nothing}

The major contribution of Mamdani's work on ethnicity and identity is his critical understanding of the difference between economic, cultural, and political identities as group formations whose boundaries are defined as part of different and sometimes overlapping processes (2001). The historical development of markets creates economic identities, the development of communities creates cultural ones, and the historical development of state formation leads to political identities (2001). Identity formation therefore should be conceptualized as part of separate political, cultural, and economic processes. While Mamdani offers an analysis of the political aspects of ethnicity in relation to state formation, here I used his theory to explain indigeneity as a political project of the Morales government. Indigeneity, however, is a highly contested concept, one that usually refers to minority groups and is used to determine who is and who is not indigenous. In Bolivia, indigeneity is further complicated as it refers to both majority and minority groups with different histories and relations to the state and the market (Canessa, 2012). Indigeneity also refers to the Bolivian state's project of crafting a national identity. For this study, I use Canessa's broad definition of indigeneity, which explains and represents the experience of local marginalized communities, with divergent relations to the state and the market, through a discourse of connections to past civilizations and to the natural environment, with a strong sense of injustice and authenticity (2012). 


\section{La Nueva Constitución Política del Estado, CPE [Bolivia’s New Political}

Constitution], defines indigenous as "pueblos indigenas originarios campesinos" [indigenous peasant originary communities], which includes Afro-Bolivians as well. Now coca farmers, indigenous migrants such as the residentes in this study, and campesinxs who were previously excluded from indigenous classifications, are now included under this umbrella term. This inclusionary approach to indigeneity should be celebrated as a step towards inclusionary citizenship. It also should be celebrated as a step away from essentialisms that marginalized indigenous peoples from citizenship rights under racist and colonial definitions of "the indian question." At the same time, this inclusionary indigeneity is also an attempt by the Bolivian state to strengthen its hegemony by establishing a monolithic but diverse, docile and national identity that knows how to replicate the logic of capitalism, this time with an ethnic flavor. In the historical formation of the state, however, the inclusion of indigenous peoples has been a common practice and is nothing new to Bolivia (Mamdani, 2001; Gustafson, 2002). Previous attempts by the Bolivian state have used labor, tribute, clientelism, violence, and neoliberal strategies of diversity as mechanisms for indigenous inclusion (MayburyLewis, 2003). The current socio-political climate in Bolivia therefore should be analyzed and understood "in reference to parallel transformations that occurred forty years earlier after the 1952 revolution, then as now the state sought to modernize political identities...[and] to legitimate centralized authority" (Maybury-Lewis, 2003, p. 275).

This time, amidst the appearance of diversity within multicultural neoliberalism in the 1990s, and an insurrectionary indigenous majority reclaiming its political power by 
taking to the streets and ousting neoliberal governments during the water wars and gas conflict of 2000, 2003, and 2005, the Bolivian state needed a different ruling strategy. This strategy however, had to be a gatopardismo: to change everything in order to change nothing, a concept that describes political strategies that allege revolutionary changes but which in practice are shallow modifications to the status quo (Cusicanqui \& De Sousa Santos, 2015). Since the Bolivian ruling class could no longer hold power based on traditional exclusionary and racist methods, it had to transform such strategies (Webber, 2017). For the Bolivian state, this meant its transformation into the other. That is, its transfiguration into an indigenist state by what Webber calls molecular transformism, where members of the popular classes are slowly transformed into the political class, absorbed into the state apparatus, thereby extending the ruling class, which portrays itself as being more inclusive and diverse (2017). By doing this, the Bolivian state affirmed itself as the one and only protector of indigenous rights, defining ethnic borders and granting rights based on the state's definition of indigeneity. This also allowed the state to maintain a prime role in decisions related to natural resources, even those located on autonomous indigenous territories, such as TCOs (communal indigenous territories) and TIOCs (indigenous peasant territories). In other words, unlike Mamdani's demand for an estrangement between cultural and political identities, the Bolivian state has conflated cultural identities with political ones through the election of Evo Morales as the first indigenous president and this has led to party affiliation as the "true" measure of indigeneity.

This conflation has been paradoxical. The TIPNIS conflict, where the state 
attempted to build a highway throughout indigenous territories without prior informed and free consultation, and its violent repression of indigenous protests against this highway, represented a turning point that revealed the contradictions and the facade of the Bolivian state. Such contradictions, however, have been an ongoing hallmark of President Morales. Don Miguel and Doña Elena's statements pointing out to these early contradictions were described in chapter five. The new CPE is also another clear example. From its beginnings, the CPE represented conflicting and antagonistic interests within la asamblea constituyente [the Constituent Assembly] charged with drafting this new socio-political and legal document.

The original idea was that social movements, so central during the water wars of 2000 and 2003, would have direct representation within the Constituent Assembly (International Crisis Group, 2007). Nevertheless, the MAS govertment conditioned the convocation of representatives in such a manner that political parties, particularly the MAS party, and groups of all factions (left, right, center), became the central decision makers. From the 255 representatives, 137 were from the MAS, and 60 from Poder Democratico Social (Democratic Social Power), a right-wing civil society group led by Tuto Quiroga (a former Bolivian president and vice president of Hugo Banzer Suarez, an dictator during the 1970s and then elected in the 1990s) (International Crisis Group, 2007). In other words, almost 80 percent of the asamblea constituyente were members of either the MAS party or this right-wing group. Throughout the document, strange political alignments are visible in, for example: a) the centrality of the state as a decision maker or manager, if not owner, of natural resources and, b) the juxtaposition of private 
and collective principles (Galindo, 2006). ${ }^{90}$

\subsubsection{Inclusionary exclusions}

For this study, the most salient contradiction of the Morales government is expressed through participants' ambiguous experience of ethnic inclusion for being indigenous and their experience of class exclusion for being campesinxs. As Doña Silvia, 51, from Puñaka, Poopó described, having a president who "was born like us, indigenous... a campesino" has had a significant impact on the emotional and psychological well-being of indigenous people, clearly expressed in the narratives of the participants in this study. This government-led ethnic inclusion has also translated into the highest levels of participation of indigenous peoples within the government, which according to the majority of participants in this study, even those critical of Morales, is perhaps the greatest accomplishment of the MAS government. On the other hand, the MAS government has experienced political unrest from the very people it claims to protect. The TIPNIS conflict that I explained in great detail in the literature review, exemplifies this unrest. In the case of TIPNIS, the Morales government used a labeling strategy where anyone opposed to or critical of his government was labeled as right-win, the opposition (akin to racists) and anti-nation (for being against the government's

\footnotetext{
${ }^{90}$ The fourth section of the constitution, in article 307 claims that: "the state recognizes and respects, protects and promotes the community based economy [emphasis by the author], that includes the production and reproduction of social life, based on the principles and values of indigenous communities" (Honorable Congreso Nacional, 2008, p. 117). Right next to it, article 308 claims that "the state recognizes and respects, protects and promotes the private initiative [emphasis by the author] so they are able to contribute to social and economic development to strength the economic independence of Bolivia" (2008, p. 177). This shows that the new CPE was modified to accommodate multiple and incompatible interests while simultaneously consolidating the centrality of the state as a main actor over natural resources. This, as I will analyze later, also represents another paradox since the new CPE also decentralized the central government, which has not led to more local, regional and indigenous autonomies but rather to more bureaucratic processes in the Andes (decentralization was also one of the goal of la Media Luna, the rightwing secessionists from the lowlands).
} 
development program). The government also pitted indigenous coca farmer migrants against TIPNIS indigenous communities.

The tensions between indigenous campesinxs and miners, particularly salient among communities in the Poopó municipality, are a case in point that mirrors the same labeling strategy and divisions the MAS government used during TIPNIS. These tensions also show how the state manipulates and conflates cultural and political identities. As Doña Elena articulated, the Morales government shakes hands with the miners, meaning it supports and it is friendly with them because they produce rents, while simultaneously his government ignores the demands of indigenous campesinxs like her. This represents nepotism not only for economic interests, but also for political ones since miners are part of Morales' political base. Miners also have a lot of experience organizing politically and they are ready to be galvanized against any group who does not support their and the state's interests.

On the other hand, indigenous campesinxs communities in this study, once considered a strong part of the political base of the MAS government, have distanced themselves from it due to its cozy relationship with the mining sector. ${ }^{91}$ This has led to their exclusions based on economic and political interests. Their class position as campesinxs makes them economically irrelevant for the state's rent seeking behavior. They do not produce profits or rents. As Don Miguel eloquently described, whoever contributes [economically] to the state has rights, and the rest do not. Their campesinidad (their condition of being campesinxs), their subsistence agriculture does not fit with the

\footnotetext{
91 is still assumed to have unconditional support for the MAS, which is only partially true as there are many communities like the ones in this study that are now critical of the MAS's economic and political alliances with the miners, coca farmers and the agro business sector in the lowlands.
} 
state's developmentalist project of progress and modernity. On top of this, they are critical of mining operations, particularly of the nationalized Huanuni mine, which place them in an oppositional situation not only to the mining sector, but also to the state. To mitigate these tensions, the Bolivian state uses its pretended ethnic legitimacy to influence indigenous communities into supporting Morales or to sideline criticism under a sort of ethnic alliance. Indigenous communities, according to this strategy, must not be critical of their own. When indigenous people such as the participants in this study break this ethnic alliance, they are labeled as 'derechistas' [right-wing], and the opposition, which as I described before connotes racist and pro-imperialist agendas.

This polarization of those who support the MAS government and those who do not, does not necessarily ignore the criticisms towards the state, but it does transform the conflict into a sort of ethno-economic conflict between indigenous groups in support and those against the MAS government. Moreover, this political ethno-alliance does have real repercussions for these communities. As Don Lucio from CEPA explained, government projects and support have been politicized, and communities who are MASistas [MAS supporters] reap significant benefits while those who are not must then navigate a strenuous bureaucratic system to obtain basic benefits. The conflict therefore is sealed as ethnic or economic, and not political, and the central role of the MAS government manipulating these identities is obscured.

In today's Bolivia, the ethnic, that is, the indian, is allowed within the nation as long as she is not too indian, a folklorist indian that wears traditional clothes when convenient, or when demanded by the state (community leaders nowadays must dress in 
indigenous clothes while having leadership roles); an indian that offers monthly rituals to Pachamama, supports the indigenist state, and reproduces the logic of the market. ${ }^{92}$ This is el indio permitido [authorized indian] that Cusicanqui (2014) defines as a sociocultural category where indigenous demands are permitted within neoliberal projects as long as such demands are cultural, not political (Hale, 2004). However, unlike other neoliberal projects that aimed at placing the indio permitido as minorities in rural areas, in this new version el indio permitido is a majority in urban cities where the state has greater control over them. Nevertheless, the purpose of el indio permitido reminds the same: to grant some cultural rights while continuing neoliberal demands (Cusicanqui, 2014). Those unwilling and unable to articulate this folklorist indian version, both in actions (production) or ideologies (subjectivities) are marginalized and also dangerously labeled as the state's dangerous other. In the eyes of the Bolivian state, the indigenous campesinx communities in this study are politically and economic irrelevant. Continuing colonial logics of domination, the Bolivian state therefore seeks to erase their indiannesss by making them modern citizens, that is, into consumers of goods and services to fulfill the state's developmentalist project of modernity.

When communities organize against these attempts, with CORIDUP as an example, the MAS government uses a divide and conquer strategy to create inter and intra group conflicts. It also uses a legal framework that in theory promotes indigenous

\footnotetext{
${ }^{92}$ As described before, I use the word indian rather than indigenous as it is used in other studies to denote the traditional subordination this term has implied (Hale, 2004). Other times, I use indian in reference to its colloquial use in Bolivia that denotes an unruly character. In this colloquial context, indian is used discriminatory to refer to indigenous people with an uppity attitude against the assumption that indigenous people are supposed to be submissive. My use of the word indian highlights this forbidden attitude that is active and unwilling to be oppressed. For this section however, I give emphasis to the subordination aspect as this relates to the state's attempt of domination.
} 
and environmental rights, but which in reality favors the the extractivist sector. I explained these contradictions by a close examination of Supreme Decree 0335 (SD 0335) and Mining and Metallurgic Law 535 (MML 535). The latter, by legally defining mining is a national priority, the state bypasses prior and informed consultation with indigenous communities. This ignores the international rights that were granted to indigenous communities and, in parallel, consolidates the state's hegemony and power over natural resources and ethnic rights. Moreover, MML 535 grants unprecedented rights over water to the mining sector while reducing the rights to water of indigenous campesinx communities. The former law, SD 0335, the state played a neutral position, that is, it pretended to be absent in the conflict between communities and miners, while in reality, the state aligned with capitalist' interests by not enforcing the mandates of SD 0335. This was evident in the meetings that CORIDUP had with government officials, and as participants described: "Los gobernantes brillaron por su ausencia" [government officials shined by their absence].

The Bolivian state is also using an increased bureaucratization of social movements to halt organizing efforts. The fact that nowadays, indigenous communities must have required signatures by their respective indigenous leaders for any meeting, project, etc. is an example. As participants complained, this does not expand indigenous leaders' power; it makes every process more bureaucratic. As Webber argues, since Bolivia did not experience a revolution, Bolivians "continue to live alongside the structures of the old state [and]...the bureaucratic logic of these structures has not been broken.” (2014, n.p.). 
The power imbalance between the state, capital, and civil society, here represented by indigenous communities, is evident and the co-optation and taming of the radical social movements that emerged in Bolivia at the beginning of the $21^{\text {st }}$ century into the state apparatus seem like a defeat. In this particular case, CORIDUP seems to surrender its efforts amidst the intense bureaucratization it has faced to achieve its goals. As participants stated, "estamos cansados" [we are tired]. Yet this is not the end of this story.

\subsection{3. "The truth about stories"}

The stories we tell, especially those about our origins, our place in the world, and our nature as peoples do shape the way we interact with our surroundings and they condition what is and what can be (King, 2003). The truth is that "stories is all we are" (King, 2003, p. 32). Therefore, we must be cautious about the stories we tell and the stories we hear. Bhattacharya's book on social reproduction theory is not a critique of but a critical and indispensable extension of Marx theory on social reproduction, offering important analytical tools to reveal the extent to which capitalism relies on extra-economic relations (2017). Yet, as other books and theories, it has a blind spot in that it exclusively examines social reproduction processes within urban settings in advanced capitalist societies while ignoring social reproduction processes outside the core. Does this mean the eventual decline of the campesinado, the peasantry, is a given? That the ongoing $\mathrm{AbD}$ in territories like the Bolivia's Altiplano is undeserving of our attention since we know the end of that story? 
The increased marketization of universities and the commodification of knowledge (Bousquet, 2008) maintain the image of capitalism as this colossal and transcendent giant that inevitable will devour everything on its path. This dissertation navigates around discussions on 'the woman question', 'the indian question' and 'the agrarian question', but not the other way around. While we question the fate of these 'others', the fate of capitalism is unquestionable, it is a given triumph. And this is precisely what hegemony means, the ideology that render us incapable of imagining a different path, as in TINA (There Is No Alternative) and that trap us into a tunnel vision where capitalism is unshakable.

The remaining mission, therefore, is to challenge and transform the triumphant story of capitalism, from the eventual decline of the peasantry to the rise of factories to deindustrialization, (Mohandesi \& Teitelamn, 2017). One way to do this is by exploring social reproduction processes in places not dominated yet by finance and debt logics (2017). We must therefore seek and find that which has always existed: the parallel coexistence of alternative yet subjugated praxis of being and relating. In this last section, I offer an application of SRT to argue that it is on the day-to-day practices of resistance within subsistence production and social reproduction where alternatives exist and where the seeds of rebellion are sow. Women's individual and community efforts of solidarity and resistance are part of collective and historical processes of indigenous liberation that have the potential to form political and unsubordinated actors. In other words, as Bhattacharya argues, social reproduction is a site of class conflict, where class struggle is not just about wages, but everything else related to life (2017). 


\subsection{Seeds of rebellion}

Despite all the efforts to erase, suffocate, and to dominate indigenous communities in Bolivia, they are still "a living organism... [where] empirical expression of a communist spirit still exist" (Webber, 2017, p. 125). ${ }^{93}$ The double residency and the constant efforts of residentes to keep their lands and their connections to their communities should not be simplified as proletarianized people going back to 'rural lifehoods' to enjoy environmental amenities, or to obtain mere economic benefits. In contaminated areas, these environmental amenities do not exist anymore. Yes, the economic advantage of having a piece of land is important, especially for intergenerational wealth, and participants did mention this relevance. But this is not the only reason. This stubbornness should be understood as defiant efforts by indigenous campesinx communities to preserve their traditional ways of life, to resist the very forces that have expelled them from their lands and "to protect the global commons of land and water on which these livelihoods depend" (Veltmeyer, 2012, p. 61).

\footnotetext{
${ }^{93}$ Various authors argue that in Bolivia, collective expressions and actions of resistance are grounded on historical and collective memories. Mamani Ramirez in El Rugir de la Multitud argues that the indigenous mobilizations in el Alto, Bolivia during the 2000 and 2003 water wars were influenced by collective memories of indigenous rebellions that happened almost a century ago in the same region (2003). Similarly, Cusicanqui and Geidel argue that the Cacique apoderado movement that evolved during the Chaco war between 1932-1935 was able to create the republic of Kollasuyu and reclaim indigenous lands based on a long memory of " anticolonial and anti-liberal resistance" (2010, p. 38). My theoretical framework or fieldwork does not account for this historical and collective memory because as a theme it appeared by the end of fieldwork, therefore I did not explore this topic in depth or gathered data to show its relevance. These collective rebellions seem to be conditioned by Andean epistemes, nevertheless, this specificity does not mean this collective memory is not universal. As in most dialectical relations, the universal is in a constant dialectical relation with the particular and vice versa (Webber, 2017). Class struggles, although specific in time and space, should be understood as collective pulsations of ongoing resistances that are conditioned by historical and political processes (Cusicanqui, 2014; Cusicanqui \& De Sousa Santos, 2015). Considering the liveliness of the political history of the Andes, particularly in the region for my fieldwork study, this deserves attention and further research.
} 


\subsubsection{Nothing extraordinary}

In this study, resistance at the community level was epitomized through CORIDUP, the grass roots organization that was able to mobilize more than 80 communities affected by mining contamination. While it is true that CORIDUP lost its momentum and that currently it has not engaged into actions against the extractivist mining sector, to view this as a defeat or the end would be a grave mistake. Participants' testimonies about CORIDUP expressed its significance and the relevance of the concrete victories it achieved. CORIDUP forced president Evo Morales to sign and approve SD 0335. ${ }^{94}$ Anyone involved in the activist world knows how difficult it is to unify and organize people, let alone mobilize them. My own experience organizing a graduate students union in the US, in a context where we were exploited but still able to afford the time and economic resources to meet, taught me that internal divisions (in our case ideological ones between leftists and pragmatists) are difficult to overcome and that they might lead groups to dissolve. Having that experience, the fact that amidst all the divisions, contradictions, and hardships that CORIDUP had to face, not to mention all the material and economic constraints that these communities experience, it was able to capture the frustrations of indigenous campesinxs and was able to transform them into mobilizations seems remarkable. But remarkable is not the right word, and I will explain

\footnotetext{
${ }^{94}$ This was possible thanks to the technical support of CEPA, which offered spaces to meet, provide law experts, and also covered some of the economic resources for mobilizations, such as transportation. This does not belittle the fact that CORIDUP is a grass roots organization; CEPA only facilitated their efforts. That CEPA had its own agenda and that it influenced CORIDUP's is possible, but the accounts of participants do not support this. One unintended consequence of CEPA is that it created the impression among some participants that it favored those communities who were very involved in CORIDUP's organizing efforts, while excluding others.
} 
this shortly. First, CORIDUP mobilized these communities by politicizing indigeneity, so what does this show about the politization of identities?

Mamdani's theory and my own work through this study shows that the politization of identities creates a polarized and antagonist relation between self and other where the quest for racial justice becomes the quest for power, particularly state power, here exemplified in the presidency of Morales. In this study, this politization is evident through the tensions between those who support the MAS government and those who do not, and between the miner-campesinx dichotomy, among others. Any criticism against the state, particularly the distribution of power and the demand of equal rights for all citizens, is silenced or it is assumed to be racist, right-winged or pro-imperialist, even when this criticism emerges from the very communities the state is supposed to protect. In the larger picture, Mamdani's analysis and my own also tap into the ambiguities of defining ethnicity and indigeneity for conceptual understanding and empirical applications. Such ambiguities have profound implications. For example, one key feature to define indigenous communities is "historical continuity with pre-colonial and/ or presettler societies" (UN, 2007). This means that the dividing line between natives and nonnatives is colonial contact. In other words, there is no indigeneity without colonialism. Besides, exclusive rights and privileges granted to indigenous communities, particularly to land, are based on the "very European belief that true citizenship is a matter of ties of blood and soil" (Kuper, 2003, p. 7). Such nativist notions and obsessions with origins might be easily manipulated by right win ideologies against immigrants, as they currently are in places like the US. 
If the polity of identities creates these explosive relations, then identities need to be depoliticized. Nevertheless, the very same argument about political identities might be used against indigenous peoples by oppressive states that view multiculturalism as divisive and as threat to national identity. The irony in this study is that the Bolivian state uses multiculturalism and plurinationalism to create a national identity, which nevertheless still leads to the oppression and dispossession of indigenous peoples. Capitalist interests eager to grab indigenous lands that are currently protected by legal definitions of indigeneity might also argue for de-politization of identities. In the case of CORIDUP and indigenous campesinx communities claiming their political agency, they have been able to organize against capitalist forces and the state by embracing indigeneity to protect their lands and their livehoods. This shows that while rights based on indigeneity might be manipulated in a quest for power, especially state power, it cannot be ignored that these demands do emerge from real injustices and real disenfranchisements committed in the past and the present. Politization of identities can be used in a quest for justice that does not seek power or control, but a quest for fair relationships, in this case, fair hydrosocial relations between indigenous campesinx communities and the mining sector. I do not pretend to offer an answer or solution to this complex issue. This requires ongoing discussions, struggles and above everything, that such discussions and struggles be led and based on the experiences and demands of the very people for whom indigeneity represents both oppression and emancipation. It is important however, to remember that power is not a given evil, it is political, it depends on the historical and socio-cultural contexts it is emerged in, and on the relations formed 
around it. And what this case study shows as a cautionary tale is that political representation of identities through state does not guarantee protection. To the contrary, what this study shows is that even and indigenist state like the MAS government is capable and willing to use an oppressed identity to reproduce the same oppressions it pretends to disobey.

For CORIDUP, the politization of identities has led to justice, exemplified in the approval of SD 0335 (although its impact is yet to be determined). It has also led indigenous campesinxs communities to become political actors, which is significant, but not remarkable. Remarkable means extraordinary, and this is not. To call these struggles extraordinary would be to ignore and erase the historical and revolutionary struggles in which indigenous campesinx communities in this region and in Bolivia have played a central role during and after colonialism. It would be to ignore and erase a long lineage of ongoing resistances where indigenous peoples have transformed their oppression into self-emancipation, constantly reclaiming and altering indigeneity in their own terms. It is not coincidence that the Andes, specifically Oruro, gave rise to Juan Lero, who alongside the legendary indigenous leader Pablo Zarate Willka, led one of the largest indigenous rebellious in Bolivian history (Ticona, 2014). And it is also not coincidence that the Huanuni municipality gave rise to one of the most radical labor movements in Latin America in the 1950s. And it is not coincidence that Bolivia became the vortex social movements against neoliberalism at the beginning of the $21^{\text {st }}$ century.

Class struggle in Bolivia is defined by indigenous liberation connected through time and space. As such, grass roots organizing efforts such as CORIDUP should be 
understood as collective pulsations of ongoing resistances that started in the past, that condition the present to create a new future. This is Pachakutik, the time-space notion of transformation that points to ongoing patterns of change where the past coexists in the present to determine the future (Gutierrez Aguilar, 2008). And as Doña Laura, 52, mentioned: "CORIDUP has awaken Oruro, showing why the environment, what we call Pachamama, is important." Rather than an end, CORIDUP is part of ongoing indigenous struggles and an emerging wave of eco-social movements referred as the "eco-territorial turn of social struggles” (Svampa, 2015, quoted from Rivera Cusicanqui, 2016, p. 65). The direction and potential of these movements is to be defined, and these would depend on class struggle, but nevertheless it is present.

\section{5. Reproduciendo otros mundos [reproducing other worlds]}

SRT pays attention to the everyday life, to the assumed concealed personal sphere as a potential site for class formation and class recomposition and unity, "a class for itself and a class in itself" (Bhattacharya, 2017, p. 39). For indigenous campesinxs women, resistance happens aqui y ahora, in the here and now. What this means is that based on women's narratives, their struggles were not necessarily directional, seeking a final victory, although at the community level they were seeking a concrete result: The construction and functioning of the Huanuni mine's tailing dam. Rather, their struggles were framed in the day-to-day action, in their sustained efforts to confront oppressive powers, such as their defiant positions towards authorities. When participants stated "estamos cansados [we are tired]" they described this state as being both tired of so much bureaucratic processes and also as tired of waiting and ready to take action. Dualities 
and ambiguities such as this one are part of Andean culture where there is an

understanding that two realities can co-exist (Cusicanqui, 2010; 2014). In this sense, women are patient and understand that significant changes to their material conditions will take time and serious collective organizational power, and at the same time, they are impatient and their actions of resistance seek to improve something today-right here right now. As Mujeres creando, the Bolivian anarcho-feminist collective argues, liberation is not a long process "this utopia is live, is urgent, it is a permanent action of destructuralization" (Galindo, 2014, p. 174). ${ }^{95}$

SRT also stresses the centrality of human labor "in [the] reproduction of society as a whole" (Bhattacharya, 2017, p. 2) which begs the question, which society? In this study, the worker (here understood in a broad sense beyond just wages) is indigenous, campesinx and female and her society is not completely dominated by capitalist entrenchments, although it has been transformed by it. In the Andes, the social reproduction of her community is marked by Andean epistemologies and the praxis of reciprocity, duality, complementarity, embodied in socio-economic systems such as Ayni and Huayanca, described before. For this study, the solidarity networks that indigenous campesinx women create among themselves and within and between communities

\footnotetext{
${ }^{95}$ I make this reference to Mujeres creando because since decades ago, this anarcho-feminist collective and movement has engaged in grassroots work and theory development with an intersectional frame. Unlike bourgeois feminist groups, Mujeres creando' activism is bottom up, pivoting the perspectives and experiences of indigenous women, of cholas, birlochas, chotas, y chota-cholas (words describing, often discriminatorily, indigenous women in the cities), working class women, and lesbians. Their activism also refers to this day to day resistance. They recently proposed a theory of Despatriarcalizacion, a concept not easy to translate, but something like a theory of de-patriarcalization, where they argue that a society cannot be decolonized without being de-patriarcalized first. In their analysis, they make a compelling argument on how colonial and patriarchal orders co-support each other, and therefore it is not possible to destroy one without destroying the other (2014). In doing this, they criticize Morales and his allegedly decolonizing projects that offer lip services to the oppression of women. This theory also stands in criticism to academia and theories of the North, which assume that theory is something that only academia is entitled or capable of producing. A criticism about how ideas and theories from the global South are presented as exotic and particular, but incapable of presenting any universality just because they come from the periphery (2014).
} 
exemplify this reproduction. Women did not label their practices as solidarity networks because as Doña Asunta succinctly explained, "that's the way we do things" and what is culture if not other than the way that a group of people do things? Andean epistemes, although subjugated, have stained and permeated the dominant culture in Bolivia. Sociologist Rivera Cusicanqui refers to the tension that "stain" alludes to in her conceptualization of chi'xi, an Aymara word that means a grey color where small stains interweave (Castro, 2018). Rivera Cusicanqui offers chi'xi as a critique to mestizaje (to mix). Mestizaje seeks harmony and docility by blending, and in chromatics, mestizaje is one color absorbing the other. In Bolivian history, mestizaje was the attempt of the dominant Eurocentric culture to erase Bolivia's indigenous roots. Chi'xi on the other hand, recognizes existing tensions and thrives on them; it does not seek harmony and blending, rather it seeks lo abigarrado, a variegated of colors in tense yet complementarity situations; "it is a dialectic without synthesis" (Cusicanqui \& De Sousa Santos, 2015, p. 84). Ch'ixi as a concept represents a critique to both the binary and dichotomous thinking of western thought where two opposites cannot co-exist, and a critique to essentialisms that portray the indigenous experience in Bolivia as either pure and good or tainting, without recognizing complex and contradicting realities. I make this reference to highlight the relational aspect of these solidarity networks. They emerge from Andean epistemes and they also emerge from the need of socio-economic support within communities, and therefore their character and tendencies do change.

The practices that women transmitted in their narratives and that I observed through my fieldwork signal the thriving of subjugated Andean knowledges such as a 
strong culture of resistance and a culture of cooperation that dominant groups in Bolivia (the bourgeois white class) have been unable to control (Webber, 2005). As the notion of ch'ixi describes, this does not mean there are no contradictions in these experiences and it does mean that indigenous communities and women have not internalized dominations. ${ }^{96}$ Similarly to the experiences of Black women that Hill Collins describe in Black Feminist Thought, this internalization is expressed for example in Bolivia having high rates of intimate partner violence, ${ }^{97}$ where one in two Bolivian women experience this type of violence (Meekers, Pallin, \& Hutchinson, 2013). ${ }^{98}$

Nevertheless, as mentioned before, in parallel there are long-standing insubordinate practices of cooperation in spaces that dominant groups deem irrelevant to control. It was intriguing that although often perceived as unimportant and oppressive, the gendered spaces of the kitchen, the markets, spacing of preparing food, where women are in charge, were also spaces of sharing stories, of preparing food together and eating together, spaces of social bonding, and as Doña Ximena, 29 described, also spaces that women used to politically train other women. ${ }^{99}$ These are women-led spaces where they engage in social reproductive activities that reproduce other worlds, other societies as

\footnotetext{
${ }^{96}$ Here I also want to be cautious not to minimize the conflicts between indigenous groups, such as the oppression and discrimination that the indigenous minority group Urus have experienced by Quechua and Aymara indigenous groups in Oruro.

${ }^{97}$ Mujeres creando offers free legal services for women who suffered domestic violence. Every time I passed by their office, there was always a long line of mostly women around 20-25 waiting to receive these services.

${ }^{98}$ Domination is also expressed through younger indigenous generations seeking to fit into western standards by looks and ideologies, such as efforts to whiten their skin color and an increasing culture of consumerism, particularly junk food (La Patria, 2015). There are also other forms of domination, such as nose surgery, the most common type of surgery in Bolivia, where people change the tiwuanacotan nose (or the aquiline, hook indian nose) for a more European look.

${ }^{99}$ In the cities, I did observe groups of women, conformed by family members, friends, neighbors and particularly comadres (the relationships built between parents and godparents of a child, which in Latin America represent strong social bonds), creating cooperation networks where they help taking care of each other children as well as older adults
} 
SRT argues. At the same time, everyday resistance remind us that these practices are both rebellious and subordinate at the same time, capturing the complexity of social reproduction.

Indigenous campesinx women, both residentes and comunarixs, are also producers that create other types of relations, not just social or economic. The affection and care that women and participants demonstrated for their animals is one example. Women grazed these animals for subsistence and economic purposes, but this does not automatically lead people to care for animals in such a sensitive manner. A recurrent concern of participants in this study was precisely the effects of mining contamination on their animals, showing a different type of relations to the non-human world, which also included mountains (expressed for example in the rituals of the community of Peñas), that is not reducible to just instrumentalist and economic purposes. In the cities, women support each other economically through practices such as pasanaku and kermesses and the construction of social relations such as comadres, which I explained in the fieldwork setting section. While men also organize and participate in these activities, women predominantly lead these spaces.

This culture of reciprocity, and cooperation expressed through multiple practices led by Ayni, where indigenous women play a central role, attest to their efforts to resist ongoing oppressions and dominations and at the same time these practices represent the reproduction of societies not yet controlled by the logic of the market. Do these practices led to la conciencia [consciousness]? Maybe, or maybe not, and I need to be careful not to create a neatly linear causal correlation. La conciencia is not unique to their 
experiences. However, in this context, la conciencia does emanate from their dual experience as producers and reproducers of indigenous ways of life, within material and socio-cultural environments that foster this awarness of their lives and positions, which in turn becomes a sort of moral guide and motor for their actions.

\subsubsection{Leading the way}

We should understand the emergent leadership roles of indigenous women leaders within their communities as a product of both localized indigenous practices based on unequal notions of gender inclusion (such as chacha-warmi) and also as part of broader demands of gender equality which have made their leadership roles more visible and less rigid, allowing now single women to be leaders. NGOs such as CEPA and its programs

of indigenous empowerment and trainings have significantly influenced the participation of women as leaders. In turn, women take and own the intersection of their experiences with oppression with the technical knowledge they gained from these trainings and from their leadership to transform their oppressions into insubordinate actions, both personal and collective. Their narratives and actions do speak truth to power and confront authoritarian figures, even when oppressive and exploitative groups such as government officials, company managers and sometimes other indigenous male leaders control their socio-political contexts (for example during meetings). The main point to highlight here is that their efforts continue everyday resistance, even when chances of victory might seem implausible.

Many indigenous campesinx women explained in great detail how they would not let other people, especially those with technical degrees (usually men), silence their 
voices and they would confront them about their concealed actions and lies. While experts described issues in reference to their technical understandings of them, indigenous campesinxs women talked from their vivid experiences with these issues, asserting their experiences and voices as equally valid and challenging therefore the presumption that only technical knowledge is legitimate. By doing this, they challenge patriarchal norms that portray the social reproductive sphere as socially and politically irrelevant. They also challenge colonial norms that grant unequal powers to some to dominate others. In their case, they demand engagement to them, and especially engagement from government officials, as equals, defying therefore the notion that their knowledges as campesinx and women are less valid.

They did this from both their individual experiences and their position as representatives of their communities. As Hill Collins argues, people resist oppressions at different levels: the personal, the community, and the systemic level, and all these three levels interconnect and represent potential sites of resistance (2000). For indigenous campesinxs women, the personal is political (Combahee River Collective, 1977) and although they did not articulate their efforts as such, their unsubordinated actions within their personal and leadership experiences are political efforts to challenge capitalist, colonial and patriarchal orders.

By constantly recreating these relationships guided by indigenous epistemes of reciprocity in everyday activities, and by constantly struggling to maintain this everyday resistance, indigenous campesinxs women are reproducing other societies that have the potential to reproduce political subjects. They are certainly planting the seeds of 
rebellion.

\subsubsection{Rooted indigeneity and building bridges}

With its inclusive yet monolithic use of indigeneity, the state manipulates indigenous communities and limits their rights to specific territories and specific productions, giving priority to groups that are capable of producing rents for the state, such as miners. The state supports indigenous communities as long as they conform to the state's plans for capitalist development, meaning the state seeks to craft an indigenous citizen that knows how to perform indigeneity, not too much like the indigenous campesinxs in this study or the TIPNIS communities, but enough to look indigenous and to reproduce the logic of the market. This is el indio permitido [authorized indian] (Cusicanqui, 2014). And so far the state has succeeded in this endeavor. While 15 years ago the indigenous urban city of El Alto was considered a slum, the boom in primary demands gave rise to an emerging indigenous petit bourgeoisie (most of them involved in commerce) that is unapologetic of its ethnicity and its new class position. Nowadays el Alto is full of cholets (a word combining chalet and cholos, a discriminatory reference to indigenous urban migrants), luxurious indigenous mansions that throw lavish parties called electro-prestes. These kinds of scenarios are complex, because on one hand, the vibrant urban indigenous identities in the cities of Bolivia and their unapologetic character should be celebrated, especially for a country like Bolivia that has tried relentlessly to erase its indigenous roots. On the other hand, these celebrations of diversity still reproduce the logic of capital and all the hierarchies attached to it. While the material realities of these indigenous groups have improved, the vast majority of 
indigenous people are still poor. Moreover, inequality in Bolivia is still high and diversity will not decrease it.

At the same time, other indigenous communities do not conform to the mandate of el indio permitido. Rather than being passive actors trapped in time and space, they are insubordinate subjects transforming their realities and claiming their space within the nation-state as indigenous and modern citizens in their own terms. Sartañani Wasuru Qhananpi (raise up with the light of yesterday), the cultural and Autochthonous center I described in chapter six, is one example. Young indigenous generations are transforming indigeneity to represent both their ancestral ways of life and a future on the making, that is, a future that is not static or fixed in the past. This is one of the many representations of the vivid, fluid and contested nature of indigeneity. Similarly, we should understand the double residency and the residentes' attempts to maintain community links as pragmatic adaptations of being indigenous to the increasing urbanization that Bolivia is experiencing. This adaption is part of globalized and assimilationist processes that force people into the cities, as well as dispossessions of lands such as the ones I described in this study, and also part of endogenous adaptions to redefine what it means to be indigenous in the $21^{\text {st }}$ century. Between these parallel and interconnected processes, there is this striking creativity and capacity of indigenous peoples in the Andes to reproduce an urban indigenous identity that revolves and is anchored in Andean practices and knowledge. It is this capacity of self-definition that allows indigenous communities to retain many aspects of their ways of life while at the same time transforms them.

Similarly, the efforts of members of Wasi Pacha (the majority indigenous women 
who live in urban areas, and who organize around issues such as food sovereignty, no MGOs, revitalization of ancestral knowledge and anti-mining struggles) are another way in which indigenous people negotiate and reclaim their indigeneity. This indigeneity builds from generational knowledge they acquired from family members (parents and grand parents), from the own experiences (no matter how short) within indigenous communities, with an authentic effort to keep connections to their communities and especially through the emphasis of indigeneity as praxis. Unlike the state's indigeneity, theirs is critical of capitalist, colonial, and patriarchal orders and it embrace actions based on these premises.

The solidarity between urban and rural spaces that indigenous women are building, here exemplified throughout the collaborative work between Wasi Pacha, and indigenous campesinxs women, should be understood as efforts to maintain indigeneity in an ever evolving and changing world. Women made clear that their indigeneity is dual and seeks connections to territories, and it is also independent from them. Their indigeneity is rooted in praxis, in the making of everyday life, in the ways one is and relates to others. This is what I call rooted indigeneity, flexible, fluid and capable of setting roots wherever it needs to be, guided by Andean epistemes of reciprocity and complementarity.

The literature on gender and anti-extractivist movements is correct in pointing out to the blind post of ignoring the experiences of indigenous women in anti-mining struggles. At the same time, the experiences and narratives of the indigenous women in this study show that while such dividing lenses between who is and who is not 
indigenous might be necessary for some issues, there is also the blind spot of real life as complex, muddy, fluid, and ever-changing that does not fit neatly in these categories. Depending on the observer, Wasi Pacha might be described as a group of mestizos because its members do not live in rural or indigenous communities. In this analysis, they self-identified as indigenous and that's how I describe and how I interpret their efforts.

Furthermore, this rooted indigeneity that is based on fluidity, duality, and praxis is capable of challenging the imposed mandates of capital, patriarchal, and colonial orders that seek to divide. Instead, this rooted indigeneity allows women in this study to build forbidden alliances across ethnic, geographical, and through gender lines to organize against extractive capitalism. They do this by recognizing the centrality of water, particularly in the sphere of social reproduction. And although mining contamination has a direct effect on indigenous campesinx women, they recognize that it also affects women and their families in urban cities through food chains (the urban city of Oruro for example still consumes a high part of its meat, diary products and crops from its surrounding rural communities). They recognize the centrality of water in social life and how it interconnects us all. As Holga from las Ramonas mentioned, their struggle therefore is "anti-colonial, anti-patriarchal, and anti-capitalist."

\subsubsection{The other Sumaq Qamaña}

"Man created his microcosms with the arquetipes of the macrocosms. The sky projected simulacrums on earth. Every earth-being corresponded to an eviterno celestial model translated in the landscape and the beings" (Condarco, 2015, p. 37). ${ }^{100}$

${ }^{100}$ Eviterno refers to something that has a beginning but not an end. 
Andean cosmovision is based on duality, reciprocity, and complementarity and the power that comes from embracing both the forces that come from earth and the forces that are cosmic and emanate from heavens (Ardeleanu, 2014). It reflects the interwoven relationship between nature, ecology, humans, and all the cosmos around creating a particular way of knowing and knowledge, a way of thinking about sustaining life around, therefore, "a distinct and dynamic epistemology" that has broader repercussions to our understandings of what is possible $(2014, \mathrm{p} . \mathrm{v})$. In his analysis of religion, cosmovisions and environmental conflicts, Gudynas, a leading scholar on neoextractivism, argues that any real alternative to the current political and environmental crisis "must work towards the deepest roots that sustain the knowledge and sensibilities of life in common and life in the environment" (2017, p. 226).

The environmental and indigenous concept of Sumaq Qamaña-buen vivir or living well, meaning to live in balance with others and with nature - emanated from the deep and localized Andean episteme of life as a relational process, based on the notions of duality, reciprocity and complementarity. Sumaq Qamaña was also a serious critique of economic development, modernity and progress (Cusicanqui, 2014; Gudynas 2017). Nevertheless, Sumaq Qamaña was co-opted by Morales and his government to denote the rights of a generalized, undefined, and globalized Pachamama (Gudynas, 2017). This allowed Morales to criticize capitalism at a global scale and to demand global rights for the environment while continuing its neo-extractivist project at the local level. Equally worse, this co-optation of Sumaq Qamaña depoliticized its radical critique of development and transformed it into this ornamental and shallow translation of living 
well, buen vivir, understood as an alternative development, and not an alternative to development. While Morales claims Sumaq Qamaña as the path forward, participants in this study argued that in their communities, "that thing... Sumaq Qamaña, does not exist." Besides showing the contradictions of the MAS government, the neutralization of this concept created a silencing of the original and radical meaning of Sumaq Qamaña and its potential as a viable alternative.

Nevertheless, scholars and activists, particularly on the Global North, still use this notion in an uncritical manner that translates into a devoted support of President Morales. But beyond this, we should re-understand Sumaq Qamaña within its radical origins as an alternative to the current political and environment crisis we are experiencing. It is not with the scope of this paper to untangle what this crisis is or how it came to be.

Nevertheless, this crisis shows the deceptive nature of the premises of development and capitalism and this is forcing us to critically look for alternatives. And any serious alternative should be framed within decolonial epistemes that question our fundamental understandings of how we relate to each other and to the world around. We must be able to recognize that in parallel to capitalism, there have always been other understandings about the world, other notions of what community means which include "spiritualties... with practices of gratitude and reciprocity with the environment" (Gudynas, 2017, p. 231).

Andean epistemes emanate from understandings of the macro cosmos (Cusicanqui, 2010, 2014; Salisbury, 2019; Zenteno, 2009). As described in the quote above, there is a sheer understanding that we, not just humans but also all earth-beings, 
are interconnected in multiple ways through the macro cosmos from which we are a projection. In The Truth About Stories, Quinn criticizes the Judeo-Christian myth of creation, which places humans above everything else and argues that stories, particularly those about our creation and origins as a people do have a real impact on the way we act in the world. Any alternative to capitalism should seek therefore to blur the gap between the individual, society, and nature (Gudynas, 2017). Yet, this is just a first step. As participants in this study emphasized, it is in the praxis of everyday resistance where one might plant the seeds of rebellion. Here, I offered this brief reflection on Sumaq Qamaña to elucidate how this indigenous philosophy is political and critical of development and the capitalist system. By offering both a political and philosophical critique of the capitalist system, and as Gudynas argues, Sumaq Qamaña offers the possibilities of other ways of being. Yet, this is only a first step, and as indigenous campesinx women showed in this study, any efforts of resistance to this crisis must be centered on praxis.

\section{Limitations}

Before the conclusions, I want to acknowledge the limitations of this study. First, I only interviewed people from four indigenous campesinx communities in the Andes. Therefore the results of this study should not be generalized to other indigenous communities in Bolivia who might be receiving socio-economic benefits under President Morales. Indigenous coca farmers might be an example of this.

I am Bolivian; therefore I had a significant advantage in carrying on this focused multi-sited ethnography. Moreover, the almost instant support of CEPA and CORIDUP also facilitated the research process. Nevertheless, the drawback of carrying 
interviews in four communities is that fieldwork in each community consequently lacks the in-depth, long-term ethnographic fieldwork they deserve. With one exception, all my visits to the communities amounted to a few weeks, and in the case of Quellia, I was unable to visit the community at all. Although in theory focused multi-sited ethnography solves these limitations by a more intense process of data collection (for example by using multiple methods or multiple interactions with participants), in practice this was difficult. The number of times I visited and/or interacted with participants was determined by logistics (distance, availability) and other factors that I took for granted such as Bolivia's known celebratory character, which means my fieldwork was carried on during many holidays, such as Todosantos or Dia de los Muertos, Christmas and Carnival, among other celebrations where people were extra busy and unable to engage in other activities, such as interviews. Fieldwork was also carried on during the rainy season, which made access to communities almost impossible. There were also ongoing rallies, marches and road blockades that made difficult to carry on interviews. For these reasons, participants frequently postponed and cancelled interviews, which had an effect on how many interviews I was able to obtain. Nevertheless, this also allowed me to conduct interviews with a great diversity of participants, settings and experiences that provided a rich and broad perspective to this issue. I also planned to have more interviews with local and national government officials. These interviews, however, were harder to obtain than what I had planned. Although I did reach these participants by phone, email, and visits to their offices, there was significant reticence to participate. By mere coincidence, I was lucky to obtain interviews with three government officials, 
which helped triangulate the other interviews.

I also need to acknowledge my limitations of knowledge about Andean cosmovision and epistemologies. Since I grew up in Bolivia, I took Andean epistemes for granted, assuming I knew a lot about them when in fact I only know very little. It was during my last weeks of fieldwork that I realized the particularity of Andean epistemes and how they affected relationships and behaviors. Although I posses some lived experience of these epistemes and I am deepening my knowledge by reading the literature on Andean cosmovision, my understanding is still very limited. Therefore, I have to be cautious not to fetishize these notions.

I also did not always have enough time to explore in the same depth the research question about indigenous women's resistances as I explored the other two questions. Questions about resistance were the last questions in the interview guide, and after two hours or more of interviews, some participants were already tired or they had limited time. Still, I do consider I gained valuable insights about this topic.

Last, in this study, I say less about gender per se, and at times it might seem I do not explore the experience of indigenous campesinx women directly. Shiva offers a similar analysis about poor, tribal and peasant women in India where gender is not exclusively explored. As Mohanty argues, it is the social location (gender, class, ethnicity, rurality, periphery) of these women from which Shiva offers a critique of "the global privatization of indigenous knowledge" (2002, p. 514). In other words, similar to Shiva, from the micro experiences of women I offer a critique of macro processes of the political economy of neo-extractivism. In this endeavor, gender is deeply intertwined 
with other relations, which makes it both difficult and not necessarily desirable, to explore it as an individual attribute, since this compartamelization might simplify the complex realities of the lives of women in this context. It is within the intersectionalities of all the social locations that indigenous, poor, and campesinx women in the global South occupy that this study analyzes the way that capitalist, colonial and patriarchal orders operate. 


\section{CONCLUSIONS}

Latin America is in a political crisis. Amidst the rise of far-right demagogues such as Jair Bolsonaro in Brazil, many argue for supporting Bolivian president Evo Morales as the lesser of two evils. Nevertheless, a closer look at the lives of indigenous campesinx women in the Bolivian Altiplano shows that even an "indigenist state" like Bolivia under Morales is willing to reproduce the same oppressions and exploitations it professes to disobey. The Morales government has claimed to turn the system upside down: yet the actual meaning of this has been to create a system where "the native... [sits] on the top of the political world designed by the settler" (Mandami, 2001, p. 658). These conclusions indicate that the path forward for radical change is through neither electoral politics, nor the politization of identities for political power. What the state looks like matters little if it is still putting forth exploitative and oppressive policies that continue the subjugation of marginalized communities.

This study re-focused attention onto assumed mundane activities such as washing clothes, cooking, and grazing animals - activities where indigenous campesinx women play a central role - to show how social reproduction is intrinsically intertwined with production processes. In this case however, a twisted version emerges where production leads to the un-reproduction of indigenous campesinx ways of life, because at its core, extractive capitalism depends on the commodification of territories and resources, not the commodification of labor. Indigenous communities therefore are expelled and dispossessed from their lands and ways of life by extractivist forces and the unabashed support of the Morales government for the mining sector. At the epicenter of these issues 
is control over access to water, which connects all of these conflicts. Water is social life - it is central in the reproduction of our communities and societies. Water therefore is social and political, and as such, its character and effects both depend on and reflect the power relations behind it. The Morales government uses a legal framework to grant unlimited rights and access to water to the mining sector while simultaneously stripping these rights from indigenous campesinx communities. Through this uneven socioecological relation, the Morales government shows that its priority is profit and rents, not indigenous communities or Pachamama.

Water also reveals the gendered and patriarchal features of extractive capitalism. Indigenous women are both producers and social reproducers within their communities, and they rely primordially on water-centric activities, such as the ones mentioned above. It might seem obvious that water is central to all these activities that reproduce life, yet studies on the effect of extractivism take this for granted. Rather than dubious connections between indigenous women and Pachamama, this analysis, based on the socio-material conditions of the lives of indigenous women, shows how lack of access to clean water has a direct, direr and gendered effect on them. Extractive capitalism therefore is not just about production, exploitation, and the commodification of nature; it is also about reproduction, oppression, and the continuity and exacerbation of colonial and patriarchal mandates that have historically placed indigenous campesinx women at the bottom of the hierarchies these mandates create.

Amidst all the power imbalances that this study addresses, indigenous women and their communities continue organizing against the political and economic forces that 
oppress them. The individual and collective efforts of indigenous campesinx women and CORIDUP are not extraordinary events; they are part of ongoing resistances that have been taking place in the Andes for centuries, where the political actor has been galvanized around her indigenous identity. These resistances depend on the sociohistorical context and the character of class struggles of the time, and in this study, this is expressed through the everyday resistance of indigenous campesinx women. The daily duties of indigenous campesinx women in production and social reproduction, which are embedded in Andean epistemologies of reciprocity, duality, and complementarity have allowed women to build solidarity networks that keep the social fabric within and between communities alive, thus becoming important sites of everyday resistance.

Indigenous campesinx women also build forbidden alliances across ethnic, geographical, and through gender lines to organize against extractive capitalism by using a fluid and dual indigeneity. I call this "rooted indigeneity", an indigeneity that seeks territorial connections and one that is also independent from them. This rooted indigeneity is capable of developing ethnic identities across spaces, and it is based on the praxis of what it means to be indigenous. In juxtaposing rooted indigeneity with the statedefined indigeneity, I show the complexity of indigeneity as a category for empirical and analytical purposes that needs further exploration. By doing this, and while occupying a tripartite axis of oppressions, indigenous campesinx women defy the very colonial, patriarchal and capitalist mandates that seek to keep them oppressed. This is everyday resistance.

In the big picture, this study highlights existing systems and epistemologies that 
run parallel to the capitalist system, which represent a threat to the hegemonic tendencies of capitalism and also provide an alternative to it. The lesson gained from indigenous campesinxs women in the Bolivian Andes is that that parallel systems and alternatives are not exogenous ideas to be implemented but rather these systems are reproduced in the everyday life - our very mundane interactions between each other have the potential to perpetuate or challenge patriarchal, colonial and capitalist mandates. Yet, Andean epistemes of reciprocity, duality and complementarity, exemplified in Sumaq Qamaña, are hollow if they are not connected to radical praxis. As indigenous campesinx women show, we have the option to reproduce the society that we seek to create in the here and now, and this desire for an alternative must be impatient, political, and unruly, even when chances of a victory seem slim. Whether Sumaq Qamaña or any other alternative represents a paradigm shift will depend on the historical development of class struggles, which in Bolivia are embedded in indigenous liberation. What is certain is that in Bolivia, indigenous people undoubtedly will play a central role, as they historically have. 


\section{REFERENCES}

Achtenberg, E. (2015). What's Behind the Bolivian Government's Attack on NGOs? NACLA. Retrieved from: http://nacla.org/blog/2015/09/03/whatpercent27sbehind-bolivian-governmentpercent27s-attack-ngos

Acosta, A. (2013). Extractivism and neo-extractivism: two sides of the same curse. In Lang \& Mokrane. Beyond Development: Alternative visions from Latin America, Quit: Rosa Luxemburg Foundation

Acosta, C. (2015). 'Decolonizing the nation-state': Indigenous Autonomy, Extractivism, and Consultation in Contemporary Bolivia. Indigeneity and International Development.

Ahlers, R., \& Zwarteveen, M. (2009). The Water Question in Feminism: Water Control and Gender Inequities in a Neo-liberal Era. Place and Culture, 16 (4), 409-426 doi 10.1080/09663690903003926

Albo, J. (1994). ¿...y de Kataristas a MNRistas? La Sorprendente y Audaz Alianza entre Aymaras y Neoliberales en Bolivia. In Indigenous peoples and democracy in Latin America. New York. St. Martin Press, pp. 55-79

Andolina, Robert, Sarah Radcliffe y Nina Laurie (2005). "Development and Culture: Transnational Identity Making in Bolivia”. Political Geography, Vol. 24, No. 6: 678-702.

Anzaldúa, G. (1987). Borderlands/La Frontera: The New Mestiza. San Francisco, CA: Aunt Lute Book Company.

App Gaceta Bolivia. (2014). Bolivia LEY No 535 del 28 de Mayo de 2014 Ley retrieved from http://www.derechoteca.com/gacetabolivia/ley-535-del-28-mayo2014/

Arbona, J. (2008). "Sangre de minero, semilla de guerrillero": Histories and memories in the organization and struggles of the Santiago II neighborhood of El Alto, Bolivia. Bulletin of Latin American Research, 27 (1), 24-42. Retrieved from URL: 
https://www.jstor.org/stable/27733974

Ardeleanu, C. (2014). An analysis of an Andean cosmovisión: nature, culture, ecology, and cosmos. Master's thesis. Retrieved from https://scholarworks.sjsu.edu/cgi/viewcontent.cgi?article $=8037 \&$ context $=$ etd_thes es

Arsel, M., \& Angel, N. A. (2012). "Stating” Nature's Role in Ecuadorian Development. Journal of Developing Societies, 28(2), 203-227. https://doi.org/10.1177/0169796X12448758

Artaraz, K., \& Calestani, M. (2015). Suma qamaña in Bolivia Indigenous Understandings of Well-being and Their Contribution to a Post-Neoliberal Paradigm by, 42(204), 216-233. https://doi.org/10.1177/0094582X14547501

Asher, K. (2017). Spivak and Rivera Cusicanqui on the Dilemmas of Representation in Postcolonial and Decolonial Feminisms. Feminist Studies, 43(3), 512-524. https://doi.org/10.15767/feministstudies.43.3.0512

Arze, C., \& Kruse, T. (2004). The Consequences of Neoliberal Reform. NACLA Report on the Americas, 38(3), 23-28. https://doi.org/10.1080/10714839.2004.11724504

Ayni Bolivia. (2018). Reciprocidad y complementariedad andina . Retrieved from http://aynibolivia.com/shop/blog/ayni-bolivia/

Bebbington, A. (2015). Political Ecologies of Resource Extraction: Agendas Pendientes. European Review of Latin American and Caribbean Studies, 100, 85-98

Becker, A. (2011). A revolution's Heritage. Retrieved from https://solidarityus.org/atc/155/p3440/

Bhattacharya, T. (2017). Social Reproduction Theory Remapping Class, Recentering Oppression. London, Pluto Press.

Bishnoi, R. (2011). Bolivia - Maternal Care for Hardest to Reach Rural Women. WUNRN. Retrieved from: http://wunrn.com/2011/02/bolivia-maternal-care-forhardest-to-reach-rural-women/ 
Borras, S., Kay, C., Gomez, S. \& Wilkinson, J. (2012). Land grabbing and global capitalist accumulation: key features in Latin America. Canadian Journal of Development Studies, 33(4), 402-416. Doi 10.1080/02255189.2012.745394

Boll, H. 2014. Hechos y Cifras: Extractivismo en America Latina. Fundacion Politica Verde

Bockman, J. (2013). Neoliberalism. Contexts, 12(3), 14-15. https://doi.org/10.1177/1536504213499873

Block, F. (1987). The Ruling Class Does not Rule: Notes on the Marxist Theory of the State. P. 51-68 in Revising State Theory. Temple University Press.

Bousquet, M. (2008). How the University Works: Higher Education and the Low-Wage Nation (Cultural Front). New York and London: New York University Press.

Burchardt, H.-J., Dietz, K. (2014). (Neo-)extractivism - a new challenge for development theory from Latin America. Third World Quarterly, 35(3), 468-486. https://doi.org/10.1080/01436597.2014.893488

Burman, A. (2015). El Ayllu y el indianismo: Autenticidad, representatividad y territorio en el quehacer político del CONAMAQ, Bolivia. In A.M. Ejdesgaard Jeppsen, H. Balslev Clausen, \& M.A. Velazquez Garcia (Eds.), Los nuevos caminos de los movimientos sociales en Latinoamerica, 100-122.

Campanini, (2014). Reflexión y Evaluación sobre Derechos y Territorios Indígenas en Bolivia. Tierra.

Campos, E. (2013). Pasanaku: una forma de ahorrar que se imita en paises vecinos. Retrieved from https://meiderdaniel.wordpress.com/2013/02/28/pasanaku-unjuego-made-in-bolivia/

Cantoral, L. (2017). Huanuni: La Mina que se Socava a si misma. Retrieved from https:/www.connectas.org/especiales/huanuni-mina/

Canessa, A. (2014). Conflict, claim and contradiction in the new "indigenous" state of Bolivia. Critique of Anthropology, 34(2), 153-173. 
https://doi.org/10.1177/0308275X13519275

Canessa, A. (2012). New Indigenous Citizenship in Bolivia: Challenging the Liberal Model of the State and its Subjects. Latin American and Caribbean Ethnic Studies, 7(2), 201-221. https://doi.org/10.1080/17442222.2012.686335

Carey, M., \& Smith, M. (1994). Capturing the group effect in focus groups: A special concern in analysis. Qualitative Health Research, 4, 123-127.

Castro, N. (2018). Descolonizando el Mestizaje. Retrieved from https://www.revistaamazonas.com/2018/08/29/descolonizando-el-mestizaje/

Catapa. (n.d). Caso: Kori Chaca. Retrieved from http://catapa.be/es/cases/bolivia/korichaca

Catapa. (n.d). Kori Chaca. Retrieved from http://catapa.be/en/cases/bolivia/kori-chaca

Catapa. (n.d). Proyecto: Cosecha de Agua alrededor del lago Poopo, Oruro Bolivia. Retrieved from http://catapa.be/es/casos/bolivia/proyecto-cosecha-de-agua

CEPA. (2009). Entrega official del Decreto Supremo 0335 (declara zona de emergenecia ambiental a Huanuni). Retrieved from https://cepaoruro.org/no544-entregaoficial-del-decreto-supremo-0335-declara-zona-de-emergencia-ambiental-ahuanuni-07-12-09/

CEPA (2009). Declaratoria Zona de Emergencia Ambiental. Serie: Cuadernos de Trabajo.

CEPA. (2012). Conclusiones del coloquio etnohistoria de Jach'a Carangas. Retrieved from https://cepaoruro.org/no713-conclusiones-del-coloquio-etnohistoria-dejacha-carangas-11-04-12/

Center for the Documentation and Information in Bolvia. (2006). Agua y Mineria en Bolivia. Tercera Edicion. CEDIB.

CEDIB. (2012). Concesiones de explotaion y exporacion minera. Retrieved from 
https://cedib.org/post_type_mapas/concesiones-de-explotacion-y-exploracionminera/

Collins, P. H. (1998), It's All In the Family: Intersections of Gender, Race, and Nation. Hypatia, 13: 62-82. doi:10.1111/j.1527-2001.1998.tb01370.x

Cohen, D., \& Crabtree, B. (2006). Semi-structured Interviews Recording Semi-Structured interviews. Qualitative Research Guidelines Project, 2. Retrieved from http://www.qualres.org/HomeSemi-3629.html

Chambilla Mamani, B. (2016). Women miners and itinerant mining work in the Chorolque Cooperative. Tinkazos, 39, 81-91.

Choque Quispe, M. (n.d). La participaction de la mujer indigena en el contexto de la asamblea constituyente. Retrieved from https://www.cepal.org/mujer/reuniones/Bolivia/M_Eugenia_Choque.pdf

Colectivo CASA. (n.d). Caso Huanuni. Retrieved from http://www.colectivocasa.org.bo/index.php?option=com_k2\&view=item\&layout= item\&id=82\&Itemid $=104$

Colectivo CASA. (n.y). Caso Huanuni. Retrieved from http://www.colectivocasa.org.bo/index.php?option=com_k2\&view=item\&layout= item\&id=82\&Itemid $=104$

Colque, G., Urioste, M., Eyzaguirre, J. (2015). Marginalizacion de la Agricultura Campesina e Indigena: Dinamicas locales, Seguridad y Soberania Alimentaria. Dinámicas locales, seguridad y soberanía alimentaria La Paz: TIERRA.

Condarco, C. (2011). La Serrania Sagrada de los Urus. Bolivia: Latinas Editores.

Cortina, R. (2014). The Education of Indigenous Citizens in Latin America. UK: Multilingual Matters.

Combahee River Collective. (1977). Combahee River Collective statement. Retrieved from http://circuitous.org/scraps/combahee.html

Corrales, J. (2018). A Perfect Marriage: Evangelicals and Conservaties in Latin America. 
New York Times. Retrieved from

https://www.nytimes.com/2018/01/17/opinion/evangelicals-politics-latinamerica.html

CPE. (2009). Nueva Constitucion Politica del Estado. Retrieved from https://www.oas.org/dil/esp/Constitucion_Bolivia.pdf

CORIDUP. (2010). La "CORIDUP" coordinadora de comunidades afectadas por la contaminación ambiental. Retrieved from http://coridup.blogspot.com/2010/05/la-coridup-coordinadora-decomunidades.html

Corporacion Andina de Fomento. (n.d). Programa Mi agua I; Mi agua II; Mi agua III. Retrieved from http://www.riegobolivia.org/programa.html?smodule=programs\&page=1\&parent $=\&$ parent $=23$

Cusicanqui, S. R. (2010). Mujeres y estructuras de Poder en Los Andes. In Violencias (Re) Encubiertas. Bolivia: Piedra Rota.

Cusicanqui, S. R. (2010). Violencias (re)encubiertas en Bolivia, 236. Retrieved from http://www.ceapedi.com.ar/imagenes/biblioteca/libros/295.pdf

Cusicanqui, S. R., \& Geidel, M. (2010). The Notion of "Rights" and the Paradoxes of Postcolonial Modernity : Indigenous Peoples and Women in Bolivia. Qui Parle: Critical Humanities and Social Sciences, 18(2), 29-54.

Cusicanqui, S. R. (2014). Mito y Desarrollo en Bolivia: El Giro Colonial del Gobierno del MAS. Bolivia: Piedra Rota.

Cusicanqui, S. R. (2015). Strategic Ethnicity, Nation, and (Neo)colonialism in Latin America. Alternautas, 2(2), 10--20. URL:

http://www.alternautas.net/blog/2015/11/5/strategic-ethnicity-nation-andneocolonialism-in-latin-america.

Cusiqanqui, S.R., De Sousa Santos, B. (2015). In Conversa del mundo. Revueltas de 
Indignacion y otras Conversas (pp.80-126). Bolivia: Stigma.

Cusiqanqui, S.R. (2016). Etnicidad estratégica, nación y (neo) colonialismo en América Latina. Alternativa Revista de Estudios Sociales. 3(5), 3-12

Deonandan, K. \& Dougherty, M, (2016). Mining in Latin America: Critical Approaches to the New Extraction. Routledge, NY.

Dorner, U., Franken, G., Liedtke, M., \& Sievers, H. (2012). Artisanal and small-scale mining (ASM). Polinares, 7. Retrieved from http://pratclif.com/2015/minesressources/polinares/chapter7.pdf

El Deber. (2018). Hirano: "Minera san Cristobal trabaja en un plan agresivo de exploración". Retrieved from https://www.eldeber.com.bo/economia/HiranoMinera-SanCristobal-trabaja-en-un-plan-agresivo-de-exploracion-201802209239.html

Eisenstein, Z. (1999). Constructing a Theory of Capitalist Patriarchy and Socialist Feminism. Critical Sociology, 25(2-3), 196-217. https://doi.org/10.1177/08969205990250020901

Einsestein, Z. (2014). An Alert: Capital is Intersectional; Radicalizing Piketty's Inequality. The Feminist Wire. Retrieved from https://thefeministwire.com/2014/05/alert-capital-intersectional-radicalizingpikettys-inequality/

El Deber. (2017). El Escandalo del Banco Union. Retrieved from https://www.eldeber.com.bo/opinion/El-escandalo-del-Banco-Union-201710240076.html

El Deber. (2018). La polución en Huanuni cause daños a mas de 40 comunidades. Retrieved from https://www.eldeber.com.bo/septimodia/La-polucion-en-Huanunicausa-danos-a-mas-de-40-comunidades--20180420-6587.html

Fabricant, N. (2010). Between the romance of collectivism and the reality of individualism: Ayllu Rhetoric in Bolivias landless peasant movement. Latin 
American Perspectives, 37(4), 88-107.

https://doi.org/10.1177/0094582X10373352

Fabricant, N. (2013). Good Living for Whom? Bolivia's Climate Justice Movement and the Limitations of Indigenous Cosmovisions. Latin American and Caribbean Ethnic Studies, 8(2), 159-178. https://doi.org/10.1080/17442222.2013.805618

Fabricant, N. \& Postero, N. (2014) Performing the 'wounded Indian': a new platform of democracy and human rights in Bolivia's autonomy movement, Identities: Global Studies in Culture and Power, 21:4, 395-411, DOI:

10.1080/1070289X.2013.828626

Fabricant, N., \& Postero, N. (2015). Sacrificing Indigenous Bodies and Lands: The Political-Economic History of Lowland Bolivia in Light of the Recent TIPNIS Debate. Journal of Latin American and Caribbean Anthropology, 20(3), 452-474. https://doi.org/10.1111/jlca.12173

Fabricant, N. (2015). The Topsy-Turvy Path to Twenty-first-Century SocialismBurbachRogerFoxMichaelFuentesFedericoLatin America's Turbulent Transitions: The Future of Twenty-first-Century Socialism. London and New York: Zed Books, 2013. Latin American Perspectives, 42(4), 113-116. https://doi.org/10.1177/0094582X15577380

Fern, E. F. (1982). The Use of Focus Groups for Idea Generation: the effects of group size, acquaintanceship, and moderator on response quantity and quality. Journal of Marketing Research, XIX(February), 1-13. https://doi.org/10.2307/3151525

Fernandez-Navarro, P., Garcia-Perez, J., Ramis, R., Boldo, E., Lopez-Abente,G. (2012). Proximity to mining industry and cancer mortality. Sci Total Environ, 66-73. doi: 10.1016/j.scitotenv.2012.07.019

Fides. (2018). Bolivia suma Bs 842 millones por regalías mineras entre enero y agosto de 2018. Retrieved from https://www.noticiasfides.com/economia/bolivia-suma-bs842-millones-por-regalias-mineras-entre-enero-y-agosto-de-2018-391623

Fitz, D. (2015). Extractivism in Latin Aamerica. Counterpunch. Retrieved from: 
http://www.counterpunch.org/2015/04/17/extractivism-in-latin-america/

Flores, E. (2004). Wijiñas, Fuente de Agua para la Ganaderia Camelida. Retrieved from https://www.ecoportal.net/temasespeciales/agua/wijinas_fuente_de_agua_para_la_ganaderia_camelida/

Flores, J., Pinto, M., Mamani, R., Terrazas, F., \& Rojas, W. (2014). La Totora y su Rol en los Sistemas de Vida del Centro de Agrobiodiversidad Cachilaya. Iniaf, 317321.

Gale, N. K., Heath, G., Cameron, E., Rashid, S., \& Redwood, S. (2013). Using the framework method for the analysis of qualitative data in multi-disciplinary health research. BMC Medical Research Methodology, 13, 117. https://doi.org/10.1186/1471-2288-13-117

Galindo, M. (2006). Evo Morales y la Descolonización Fálica del Estado Boliviano. Un análisis feminista sobre el proceso a la Asamblea Constituyente en Bolívia. Ephemera, 6 (3), 323-334. Retrieved from http://www.ephemerajournal.org/sites/default/files/6-3galindo.pdf

Galindo, M. (2014). A despatriarcar. Feminismo Urgente. Bolivia, Lavaca.

Gandarillas, M. (2016). la orientacion extractivista de la inversion publica en bolivia Cambios institucionales y normativos bajo el imperativo exportador. Observatorio del Desarrollo, 22, 1-10

Garcia Linera, A. (2013). Geopolitica de la Amazonia: Poder hacendal-patrimonial y acumulacion capitalista. La Paz, Bolivia, Vicepresidencia del Estado Plurinacional.

Galeano, E., Belfrage, C., \& Aleede, I. (1997). Open Veins of Latin America: Five Centuries of the Pillage of a Continent. NYU Press. Retrieved from http://www.jstor.org/stable/j.ctt9qfzgp

Gareca, J. (2009) Breve Historia de Huanuni. El Makipura. Retrieved from http://makipura.blogspot.com/2009/01/huanuni.html 
Green, J. (2006). Analyzing Data from Focus Groups. Applied Rural Sociology

Gruberg, H., \& Andreucci, D. (2015). Evaluacion de la Gestion Socio-Ambiental del sector en Bolivia. El Caso de la Cuenca del Lago Poopo. Cochabamba, Bolivia: Estudio MAU.

Gudynas, E. (2011). El Nuevo Extractivismo Progresista En America Del Sur. Centro Latino Americano de Ecología Social (CLAES), 75-92 Retrieved from http://www.gudynas.com/publicaciones/capitulos/GudynasExtractivismoTesisCol onialismo11.pdf

Glassman, J. (2006). Primitive accumulation, accumulation by dispossession, accumulation by "extra-economic" means. Progress in Human Geography, 30(5), 608-625. https://doi.org/10.1177/0309132506070172

Greenwald, G. (2018). Roger Waters, Marielle Franco, and the Power of Inspiration in the Face of Darkness and Danger. The Intercept. Retrieved from https://theintercept.com/2018/10/25/roger-waters-marielle-franco-and-the-powerof-inspiration-in-the-face-of-darkness-and-danger/

Grosfoguel, R. (2016). Del «extractivismo económico» al «extractivismo epistémico»y al «extractivismo ontológico»: una forma destructiva de conocer, ser y estar en el mundo. Tabula Rasa, 24, 123-143.

Gutierres Aguilar, R. (2008). Los ritmos del Pachakuti Movilización y levantamiento popular-indigena en Bolivia. Buenos Aires: Tinta Limon

Hale, C. (2004). Rethinging Indigenous Politics in the Era of the "Indio permitido". NACLA Report on the America, 38(2), 16-21.

Doi:10.1080/1074839.2004.11724509

Hall, S. (1996) "When was 'the post-colonial'? Thinking at the limit.” In: Chambers, I. and Curti, L. eds. The Post-Colonial Question: Common Skies, Divided Horizons. London: Routledge. 
Hall, D. (2013). Primitive Accumulation, Accumulation by Dispossession and the Global Land Grab. Third World Quarterly, 34(9), 1582-1604. https://doi.org/10.1080/01436597.2013.843854

Harvey, D. (2003). The New Imperialism. Oxford University Press.

Harvey, David (2005). A Brief History of Neoliberalism. Oxford University Press.

Haiphong, D. (2014). The Prospects and Problems of 21 st Century Socialism in the US. Black Agenda Report. Retrieved from:

https://www.blackagendareport.com/content/prospects-and-problems-21stcentury-socialism-us-0

Hausermann, H., \& Ferring, D. (2018). Unpacking Land Grabs: Subjects, Performances and the State in Ghana's "Small-scale" Gold Mining Sector. Development and Change, 49(4), 1010-1033. https://doi.org/10.1111/dech.12402

Healy, K., \& Paulson, S. (2000). Political Economies of Identity in Bolivia 1952-1998. Journal of Latin American Anthropology, 5(2), 2-29. https://doi.org/10.1525/jlca.2000.5.2.2

Hickel, J. (2012). Social Engineering and Revolutionary Consciousness: Domestic Transformations in Colonial South Africa. History and Anthropology, 23(3), 301322. https://doi.org/10.1080/02757206.2012.697059

Hinojosa, L., Bebbington, A., Cortez, G., Chumacero, J. P., Humphreys Bebbington, D., \& Hennermann, K. (2015). Gas and Development: Rural Territorial Dynamics in Tarija, Bolivia. World Development, 73, 105-117. https://doi.org/10.1016/j.worlddev.2014.12.016

Hsieh, H.-F., \& Shannon, S. E. (2005). Three Approaches to Qualitative Content Analysis. Qualitative Health Research, 15(9), 1277-1288. https://doi.org/10.1177/1049732305276687

Hill, T. S. (2015, July 31). Will oil and gas lift Bolivians out of poverty? Retrieved from http://latincorrespondent.com/2015/07/will-oil-gas-lift-bolivians- 
poverty/\#M7UuF2RuIjCEG7wC.97

Hill Collins, P. (2000). Black Feminist Thought: Knowledge, Consciousness and the Politics of Empowerment. Routledge, NY.

Hylton, F., \& Thomson, S. (2004). The Roots of Rebellion I: Insurgent Bolivia. NACLA Report on the Americas, 38(3), 15-19. https://doiorg.proxy.lib.pdx.edu/10.1080/10714839.2004.11724502

Hylton, F., \& Thomson, S. (2005). The chequered rainbow. NLR, 35. Retrieved from https://newleftreview.org/issues/II35/articles/forrest-hylton-sinclair-thomson-thechequered-rainbow

Hoey, B. (2014). A Simple Introduction to the Practice of Ethnography and Guide to Ethnographic Fieldnotes. Marshall Digital Scholar. Retrieved from http://mhsdp.weebly.com/uploads/1/5/8/7/15875986/asimpleintroductiontotheprac ticeofethnographyandguidetoethnographicfieldnotes.pdf

Hollander, J. A., \& Einwohner, R. L. (2004). Conceptualizing Resistance. Sociological Forum, 19(4), 533-554. https://doi-org.proxy.lib.pdx.edu/10.1007/s11206-0040694-5

Hollender, R. (2016). Capitalizing on Public Discourse in Bolivia - Evo Morales and Twenty-first Century Capitalism. Columbia Academic Commons. https://doi.org/10.7916/D8JD4WMG

Horowitz, L., \& Watts, M. (2016). Grassroots Environmental Governance. Community engagements with Industry. London \& New York, Routledge.

Ingold, T. (2014). That's enough about ethnography! HAU: Journal of Ethnographic Theory, 4(1), 383-395. https://doi.org/10.14318/hau4.1.021

Instituto Nacional de Estadistica. (2013). Principales Resultados del Censo Nacional de Poblacion y Vivienda 2012. Estado Plurinacional de Bolivia. Retrived from http://ibce.org.bo/images/publicaciones/Resultados-Censo-2012.pdf

Instituto Nacional de Estadistica. (2019). Bolivia: Exportaciones, segun actividad 
económica. Resumen Estadístico. Retrieved from file:///Users/gisela/Downloads/RE_EXPORTACIONES_2018dic.pdf

International Crisis Group. (2007). Bolivia's New Constitution: Avoiding Violent Confrontation. Crisis Group Latin America Report. 23, 1-27. Retrieved from https://www.crisisgroup.org/latin-america-caribbean/andes/bolivia/bolivia-s-newconstitution-avoiding-violent-confrontation

Jacoby, H. (1969). The Bureaucratization of the World. Berkeley Los Angeles London: University of California Press

Jaffee, D., \& Newman, S. (2013). A More Perfect Commodity: Bottled Water, Global Accumulation, and Local Contestation. Rural Sociology, 78(1), 1-28. https://doi.org/10.1111/j.1549-0831.2012.00095.x

Jaffee, D., \& Case, R. A. (2018). Draining us dry: scarcity discourses in contention over bottled water extraction. Local Environment, 23(4), 485-501. https://doi.org/10.1080/13549839.2018.1431616

Jenkins, K. (2014). Women, mining and development: An emerging research agenda. The Extractive Industries and Society: An International Journal, 1(2), 329-339. https://doi.org/10.1016/j.exis.2014.08.004

Johnston, J., \& Kozameh, S. (2013). Venezuelan Economic and Social Performance Under Hugo Chávez, in Graphs. Center for Economic and POliciy Research. Retrieved from: http://cepr.net/blogs/the-americas-blog/venezuelan-economicand-social-performance-under-hugo-chavez-in-graphs

Jordan, J. (2018). Code-Switching in Gloria Anzaldúa's Borderlands/La Frontera: The New Mestiza and Sandra Cisnero's Caramelo. The Pegasus Review. 9 (2), 103109. Retrieved from https://urj.ucf.edu/docs/jordan.pdf

Joy, K. J., Kulkarni, S., Roth, D., \& Zwarteveen, M. (2014). Re-politicizing water governance: exploring water re-allocations in terms of justice. Local Environment, 19(9), 954-973. https://doi.org/10.1080/13549839.2013.870542 
Jordan, J. (2018). Code-Switching in Gloria Anzaldúa's Borderlands/La Frontera: The New Mestiza and Sandra Cisnero's Caramelo. The Pegasus Review: Univeristy of Central Florida Undergraduate Research Journal, 9(2), 103-109. Retrieved from https://urj.ucf.edu/docs/jordan.pdf

King, T. (2003). The Truth About Stories. A narrative by Thomas King. Toronto, ON: House of Ananansi.

Kolodin, S., Rodriguez,G., Alegria-Flores, K. (2015). Asuntos de familia: Estudio cualitativo sobre las redes sociales durante el embarazo y parto en Mesoamérica Chiapas-México, Guatemala, Panamá, Honduras y Nicaragua. Washington, DC: Banco Interamericano de Desarrollo.

Klein, N. (2007). The Shock Doctrine: The Rise of Disaster Capitalism. New York: Henry Holt and Company.

Knoblauch, H. (2005). Focused ethnography. Forum Qualitative Sozialforschung, 6(3). https://doi.org/10.1017/CBO9781107415324.004

Kuper, A. (2003). The Return of the Native. Current Anthropology, 44(3), 389-402. https://doi-org.proxy.lib.pdx.edu/10.1086/368120

Krueger, R. A. (1998). Krueger - Developing questions for focus groups.pdf. Focus group kit (Vol. 3). https://doi.org/10.4135/9781483328126

Lander, E. (2016). The implosion of Venezuela's rentier state, (September), 1-22.

Lahiri Dutt, K., \& Mcintyre, M. (2006). Women Miners in Developing Countries: Pit Women and Others (2006). Ashgate Publishing

Lahiri Dutt, K. (2011). Digging women: towards a new agenda for feminist critiques of mining. Gender, Place \& Culture, 1-20

Lahiri-Dutt, K. (2012). Digging women: towards a new agenda for feminist critiques of mining. Gender, Place \& Culture, 19(2), 193-212. https://doi.org/10.1080/0966369X.2011.572433

Lalander, R. (2014). Rights of Nature and the Indigenous Peoples in Bolivia and 
Ecuador : A Straitjacket for Progressive Development Politics?. Iberoamerican Journal of Development Studies, 3 (2), 148-172.

http://dx.doi.org/10.2139/ssrn.2554291

La Patria. (2015, March 6). Hay que frenar el consumismo. La Patria Editorial. Retrieved from http://lapatriaenlinea.com/?fecha=2019-05-06

La Tinta (2018). Silvia Rivera Cusicanqui Parte 1: "Un llamado a repolitizar la vida cotidiana". Retrieved from https://latinta.com.ar/author/admin/

Laurie, N., Andolina, R., \& Radcliffe, S. (2005). Ethnodevelopment: Social movements, creating experts and professionalising indigenous knowledge in ecuador. Antipode, 37(3), 470-495. https://doi.org/10.1111/j.0066-4812.2005.00507.x

Lauren, Catapa. (February 3, 2018). Personal communication.

Li, T. M. (2010). To Make Live or Let Die? Rural Dispossession and the Protection of Surplus Populations. Antipode, 41, 66-93. https://doi.org/10.1111/j.14678330.2009.00717.x

Li, X. (2015). Accounting Conservatism and the Cost of Capital: An International Analysis. Journal of Business Finance \& Accounting, 42(5-6), 555-582. https://doi.org/10.1111/jbfa.12121

Lopez Florez, P. (2013). Disputa por la Autonomía Indígena y la plurinacionalidad en Bolivia: (Resistencias comunitarias al neo-extractivismo y al Estado-nación). Instituto Italiano de Ciencia Humana - Universidad de Milán

Lopez, E., \& Vertiz, F. (2015). Extractivism, Transnational Capital, and Subaltern Struggles in Latin America. Latin American Perspectives, $X X(\mathrm{Xxx}), 1-17$. https://doi.org/10.1177/0094582X14549538

Lora, M. (2010). Psicoanálisis y religión . Una lectura de la hoja sagrada de la coca. Universidad Catolica Boliviana, 24, 217-223.

Lucas, K., \& Steimel, S. J. (2009). Creating and Responding to the Gen(d)eralized Other: Women Miners' Community-Constructed Identities. Women's Studies in 
Communication, 32(3), 320-347.

https://doi.org/10.1080/07491409.2009.10162393

Los Tiempos. (2018). Desplazan personal de inteligencia tras emboscada a policías.

Retrieved from http://www.lostiempos.com/actualidad/pais/20180804/desplazanpersonal-inteligencia-emboscada-policias

Lucha de Clases. (2011). Los Mineros y Las Nacionalizaciones; el Caso Sinchi Wayra.

Retrieved from https://www.luchadeclases.org.bo/los-mineros-y-lasnacionalizaciones-el-caso-sinchi-wayra/

Maclean, K. (2014). Chachawarmi: Rhetorics and lived realities. Bulletin of Latin American Research, 33(1), 76-90. https://doi.org/10.1111/blar.12071

Mamani, J. (2018, March 15). Personal communication.

McLafferty, I. (2004). Methodological Issues in Nursing Research Focus group interviews as a data collecting strategy. Journal of Advanced Nursing, 48(2), 187194. https://doi.org/10.1111/j.1365-2648.2004.03186.x

McMichael, P. (2012). Development and Social Change: A Global Perspective. Thousand Oaks: Sage.

Mamdani, M. (2001). When Victims Become Killers: Colonialism, Nativism, and Genocide in Rwanda. Princeton University Press.

Mamdani, M. (2001b). Beyond Settler and Native as Political Identities: Overcoming the Political Legacy of Colonialism. Comparative Studies in Society and History 43(4), 651-664.

Mamdani, M. (2013). Define and Rule Native as Political Identity. Harvard U. Press. Cambridge

Marcus, G. (1995). Ethnogrphay in/og the World System: The Emergence of Multi-Sited Ethnography. Ann. Rev. Ant, 25), 95-117

Marston, A. (2013, November 12). The Other Side of Cooperation: Cooperative Mines in Bolivia. Retrieved April 10, 2016, from http://clas.berkeley.edu/research/other- 
side-cooperation-cooperative-mines-bolivia

Mayer-Foulkes D, \& Larrea C. (2007). In: Racial and ethnic disparities in health in Latin America and the Caribbean. Giuffrida A, editor. Washington, D C: InterAmerican Development Bank, Social Protection and Health Division, Country Department, Andean Group; 2007. Racial and ethnic health inequities: Bolivia, Brazil, Guatemala, Peru; pp. 131-137.

Maybury-Lewis, D. (2003) Indigenous Peoples, Ethnic Groups and the State. Harvard University Press: Cambridge.

Mcdonell, E. (2018). The Quinoa Boom Goes Bust in the Andes. NACLA. Retrieved from https://nacla.org/print/11527

Meekers, D., Pallin, S. C., \& Hutchinson, P. (2013). Intimate partner violence and mental health in Bolivia. BMC Women's Health, 13(1), 1-16. https://doi.org/10.1186/1472-6874-13-28

Ministerio de Autonomia. (2009). Serie Bolivia Autonómica N. 2. Retrieved from https://docplayer.es/13842497-Serie-bolivia-autonomica.html

Ministerio de Justicia. (2008). Plan nacional para la igualdad de oportunidades "mujeres construyendo la nueva bolivia para vivir bien". Retrieved from http://www.bivica.org/upload/mujeres-igualdad-oportunidades.pdf

MMAyA. (n.d). Bolivia analiza los proyectos presentados para el programa MiAgua sobre saneamiento y agua potable. Retrieved from https://www.iagua.es/noticias/mmaya/bolivia-analiza-proyectos-presentadosprograma-miagua-saneamiento-y-agua-potable

Miliband, R. (1983). State Power and Class Interests. The New Left Review, 138, 57-68

Moore, J. (2010). “This lofty mountain of silver could conquer the whole world": Potosí and the political ecology of underdevelopment, 1545-1800[1]. The Journal of Philosophical Economics, 4, 58. Retrieved from http://proquest.umi.com/pqdweb/?did=2211172971\&Fmt=7\&clientId=9268\&RQ 
$\mathrm{T}=309 \& \mathrm{VName}=\mathrm{PQD}$

Mohandesi, S., Teitelamn, E. Without Reserves. In Social Reproduction Theory Remapping Class, Recentering Oppression (pp. xx-xx). London, Pluto Press.

Mohanty, C. (2002). "Under Western Eyes" Revisited: Feminist Solidarity through Anticapitalist Struggles. In Feminism without Borders: Decolonizing Theory, Practicing Solidarity (2003). Duke U. Press

Mohanty, C. (2003). Feminism without borders : Decolonizing theory, practicing solidarity. Durham, London: Duke University Press.

Marcus, G. E. (1995). Ethnography in/of The World System: The Emergence of MultiSited Ethnography. Annual Review of Anthropology, 24, 95-117. https://doi.org/10.1146/annurev.an.24.100195.000523

Morgan, D. L. (1996). Focus Groups. Annual Review of Sociology, 22(1), 129-152. https://doi.org/10.1146/annurev.soc.22.1.129

Morgan, D. (2017, March 20). Personal Communication.

Muehlmann, S. (2009). How do real Indians fish? Neoliberal multiculturalism and contested Indigeneities in the Colorado delta. American Anthropologist, 111(4), 468-479. https://doi.org/10.1111/j.1548-1433.2009.01156.x

Naicker, I. (2011). The Search for Universal Responsibility: The cosmovision of Ubuntu and the humanism of Fanon. Development, 54(4), 455-460. https://doi.org/10.1057/dev.2011.84

Li, T. M. (2000). Articulating Indigenous Identity in Indonesia: Resource Politics and the Tribal Slot. Source: Comparative Studies in Society and History, 42(1), 149-179. https://doi.org/10.1017/S0010417500002632

OCMAL. (2007). Por agua, tierra, territorio y la vida. Retrieved from https://www.ocmal.org/3664/

Owen, J. R., \& Kemp, D. (2015). Mining-induced displacement and resettlement: a 
critical appraisal. Journal of Cleaner Production, 87, 478-488.

https://doi.org/10.1016/j.jclepro.2014.09.087

Onwuegbuzie, A. J., Dickinson, W. B., Leech, N. L., \& Zoran, A. G. (2009). A

Qualitative Framework for Collecting and Analyzing Data in Focus Group

Research. International Journal of Qualitative Methods, 8(3), 1-21.

https://doi.org/10.1177/160940690900800301

PAHO. (2012). Bolivia. Health in the Americas. Retrieved from

https://www.paho.org/salud-en-las-americas-

2012/index.php?option $=$ com_docman\&view $=$ download\&category_slug $=$ hia2012-country-chapters-22\&alias=117-bolivia-117\&Itemid=231\&lang=en

Peet, R., \& Hartwick, E. (2009). Theories of Development: Contentions, Arguments, Alternatives. The Guildford Press. https://doi.org/10.1080/13563475.2010.490669

Pellow, D. N. (2016). Environmental justice and rural studies : A critical conversation and invitation to collaboration. Journal of Rural Studies, 1-6. Retrieved from https://doi.org/10.1016/j.jrurstud.2016.06.018

Perales, V. (2010). Conflictos Geopoliticos por el Agua en las Cuencas Mineras del Departamento de Oruro, Bolivia. Vertigo, 7, 1-10. Doi 10.4000/vertigo.9769

Peralta, P. (2014). Bolivia's Conamaq Indigenous Movement: “We will not sell ourselves to any government or political party". Upside Down World. Retrieved from http://upsidedownworld.org/archives/bolivia/bolivias-conamaq-indigenousmovement-we-will-not-sell-ourselves-to-any-government-or-political-party/

Perreault, T. (2012). Natural gas, indigenous mobilization and the Bolivian state, (12), ii27.

Perreault, T. (2013). Dispossession by accumulation? Mining, water and the nature of enclosure on the Bolivian altiplano. Antipode, 45(5), 1050-1069. https://doi.org/10.1111/anti.12005

Perreault, T. (2014). Minería, agua y justicia social en los Andes : experiencias 
comparativas de Perú y Bolivia. La Paz, Bolivia: Fundación PIEB

Pink, S., \& Morgan, J. (2013). Short-Term Ethnography: Intense Routes to Knowing. Symbolic Interaction, 36(3), 351-361. https://doi.org/10.1002/symb.66

Poppe, R. (2003). Interior Mina, Testimonio. Bolivia: Plural editors

Postero, N. \& Zamosc, L. (2004). The Struggle for Indigenous Rights in Latin America. Brighton: Sussex Academic Press.

Quillaguaman, E. (2016, February). Oruro, su Historia y la Empresa Minera San Jose. La Razon, retrieved from http://www.lapatriaenlinea.com/?nota=247750

Rae, H. (2002). State identities and the homogenisation of peoples. Cambridge Studies in International Relations, (84), xiii, 351 . https://doi.org/10.1017/CBO9780511491627

Radcliffe, s. (2014). El Género y la Etnicidad Como Barreras para el Desarrollo: Mujeres Indígenas, Acceso a Recursos en Ecuador en Perspectiva Latinoamericana. Eutopia, 5, 11-34.

Ramírez Hita S. (2014). Aspectos interculturales de la reforma del sistema de salud en Bolivia. Rev Peru Med Exp Salud Publica, 31(4):762-8.

Ravindran, T. (2015). Beyond the Pure and the Authentic: Indigenous modernity in Andean Bolivia. AlterNative: An International Journal of Indigenous Peoples, 11(4), 321-333. https://doi.org/10.1177/117718011501100401

Robinson, W. (2011). Latin America's Left at the Crossroads. Aljazeera news. Retrieved from: http://www.aljazeera.com/indepth/opinion/2011/09/2011913141540508756.html

Rogatyuk, D. (2016). Bolivia: Evo loses re-election bid in narrow vote. Green Left Weekly, 1085. Retrieved from https://search.informit.com.au/documentSummary; $\mathrm{dn}=886560902415226$;res=IE LHSS

Rousseau, S. (2011). Indigenous and Feminist Movements at the Constituent Assembly in 
Bolivia. Latin American Research Review, 46(2), 5-28. https://doiorg.proxy.lib.pdx.edu/10.1353/lar.2011.0020

Rousseau, S \& Morales, A. (2015). Paths towards Autonomy in Indigenous Women's Movements: Mexico, Peru, Bolivia. J. Lat. Amer. Stud, 48, 33-60.

Ross, M. L. (2001). Does Oil Hinder Democracy? Source: World Politics, 53160180(3), 325-361. https://doi.org/10.1353/wp.2001.0011

Rodriguez, I., \& Inturias, M. (2016). Cameras to the people: Reclaiming local histories and restoring environmental justice in community based forest management through participatory video. Alternautas, 3(1), 32-49.

Rodriguez Montoya, O. (2019). Elaboracion de mapas sobre trabajo de campo de este estudio.

Safransky, S., \& Wolford, W. (2011). Contemporary land grabs and their alternatives in the Americas. International Conference on Global Land Grabbing. Brighton, University of Sussex, (April), 6-8.

Salisbury, M. (2019, Febrary, 25). Personal communication

Sanchez Echevarria, M. (2015). Ser "Bartolina" en tiempos de Cambio. Procesos de Construcción Identitaria de la Confederación Nacional de Mujeres Campesinas Indígenas Originarias de Bolivia "Bartolina Sisa" en el Estado Plurinacional. CLACSO, Buenos Aires. Retrieved from http://biblioteca.clacso.edu.ar/clacso/becas/20150808105038/360.pdf

Sanchez, L. (2009). Declaratoria de zona de emergencia ambiental de la subcuenca Huanuni por actividades mineras y Gestiones Desde El Año 2007. Observatorio Latinoamericano de Conflictos Ambientales. Retrieved from http://olca.cl/oca/bolivia/mineras021.html

Sanchez, L. (November 20, 2017). Personal communication.

Sankey, K., \& Munck, R. (2016). Rethinking Development in Latin America: The Search for Alternative Paths in the Twenty-first Century. Journal of Developing Societies 
(Sage Publications Inc.), 32(4), 334-361.

https://doi.org/10.1177/0169796X16670296

Savino, L. (2015). Landscapes of contrast: The neo-extractivist state and indigenous peoples in "post-neoliberal" Argentina. Extractive Industries and Society, 3, 404415. https://doi.org/10.1016/j.exis.2016.02.011

Schilling-Vacaflor, A. (2013). 'Prior Consultations in Plurinational Bolivia: Democracy, Rights and Real Life Experiences', Latin America and Caribbean Ethnic Studies, 8:2 (2013), pp. 202-220

Seoane, J. (2012). Neoliberalismo y ofensiva extractivista. Theomai, 26, 27.

Shah, A. (2007). The Dark Side of Indigeneity?: Indigenous People, Rights and Development in India. History Compass, 5(6), 1806-1832. https://doi.org/10.1111/j.1478-0542.2007.00471.x

Shah, A. (2010). In the shadows of the state: Indigenous politics, environmentalism, and insurgency in Jharkhand, India, 6150 (February). https://doi.org/10.1080/03066150.2013.801639

Sinha, S. (2006). Patriarchy, Colonialism and Capitalism: unerathing the History of Adivasi Women Miners of Chotanagour. In Lahiri Dutt, K., \& Mcintyre, M. (2006). Women Miners in Developing Countries: Pit Women and Others (2006). Ashgate Publishing

Spoon, J. \& Arnold, R. (2012). Collaborative Research and Co-Learning: Integrating Nuwuvi (Southern Paiute) Ecological Knowledge and Spirituality to Revitalize a Fragmented Land. Journal for the Study of Religion Nature and Culture 6(4). DOI: $10.1558 /$ jsrnc.v6i4.477

Spronk, S. (2006). Cochabamba Water war in Bolivia by Oscar Olivera and Tom Lewis. Labour/Le Travail. 57, 237-239.

Springer, S. (2016). Fuck Neoliberalism. ACME: An International E-Journal for Critical Geographies, 15(2), 285-292. Retrieved from 
http://search.ebscohost.com.proxy.lib.pdx.edu/login.aspx?direct=true\&db=aph\&A $\mathrm{N}=116840217 \&$ site $=$ ehost-live

Stavenahgen, (1994). N.T. In Van Cott, D. (1994). Indigenous Peoples and Democracy in Latin America. Palgrave Macmillan.

Spivak, G. C. (1988). Spivak 1988.Pdf. Marxism and the Interpretation of Culture. https://doi.org/10.1353/aiq.2003.0026

Suarez y Suarez, M. (2014). Breve resena de la situacion del sector minero en el estado plurinacional de Bolivia. Retrieved from https://sillac.com/wpcontent/uploads/2018/02/articulo-mineria.pdf

Svampa, M. (2012). Consenso de los Commodities, Giro Ecoterritorial y Pensamiento crítico en América Latina Maristella. OSAL Observatorio Social de América Latina, 32, 15-38.

Svampa, M. (2015), The 'Commodities Consensus' and Valuation Languages in Latin America, Alternautas, 2 (1),45-59.

URL:http://www.alternautas.net/blog/2015/4/22/the-commodities-consensus-andvaluation-languages-in-latin-america-1

Stewart, D. W., \& Shamdasani, P. N. (1990). Focus groups : theory and practice. Applied social research methods series (Vol. 20). Retrieved from http://www.loc.gov/catdir/toc/ecip0610/2006009180.html

Smith, D. (2006). Digging Through Layers of Class, Gender and Ethnicity: Korean Women Miners in Prewar Japan. In Lahiri Dutt, K., \& Mcintyre, M. (2006). Women Miners in Developing Countries: Pit Women and Others (2006). Ashgate Publishing.

Tabra, S. (n.d). Bolivia: resultados del censo 2012 causa polemica por reduccion de poblacion indigena. Servindi. Retrieved from file://Users/gisela/Downloads/servindi__servicios_de_comunicacion_intercultural__bolivia_resultados_del_censo_2012_causa_polemica_por_reduccion_de_poblaci 
on_indigena_-_2013-08-08.pdf

Tailing dam. (n.d). In Wikipedia. Retrieved January, 03, 2019 from

https://en.wikipedia.org/wiki/Tailings_dam

Taylor, K. (2016). From BlackLivesMatter to Black liberation. Chicago, Illinois: Haymarket Books

TeleSur. (2018). 6 Dead so Far in Bolivian Floods. Retrieved from https://www.telesurenglish.net/news/6-Dead-So-Far-in-Bolivian-Floods20180204-0025.html

The democracy Center. (2008). Bolivian racism runs amok in Sucre. Retrieved from http://democracyctr.org/blogfrombolivia/bolivian-racism-runs-amok-in-sucre/

The Guardian. (2016, August 26). Bolivian deputy interior minister beaten to death by miners. Retrieved from https://www.theguardian.com/us

The United Nations General Assembly. (2007). Declaration on the Rights of Indigenous People. Retrieved from https://www.un.org/development/desa/indigenouspeoples/declaration-on-therights-of-indigenous-peoples.html

Tschopp, M. (2018). The quinoa boom and the commoditisation debate: critical reflections on the re-emergence of a peasantry in the Southern Altiplano. Alternautas, 5 (1), 64-81. Retrieved from https://static1.squarespace.com/static/5362250de4b0e6ed7cf86ed1/t/5b86e18521c 67c412e14b941/1535566219949/journalv5i1_2018_final.pdf\#page=64

The World Bank. (2015). Profile: Bolivia overview. Retrieved from: http://www.worldbank.org/en/country/bolivia/overview

The World Bank. (2015). Profile: Ecuador overview. Retrieved from: http://www.worldbank.org/en/country/ecuador/overview

The World Bank (2019). Bolivia country profile. Retrieved from http://www.worldbank.org/en/country/bolivia 
Ticona, A. (2014, May 4). Juan Lero Presidente del gobierno indio 1899. La Razon. Retrieved from http://www.la-razon.com/

Tschopp, M. (n.d). The Quinoa Boom and the Commoditisation Debate: Critical Reflections on the Re-emergence of a Peasantry in the Southern Altiplano. Alternautas. Retrieved from http://www.alternautas.net/blog/2018/3/21/thequinoa-boom-and-the-commoditisation-debate-critical-reflections-on-the-reemergence-of-a-peasantry-in-the-southern-altiplano

Thomas, D. R. (2006). A General Inductive Approach for Analyzing Qualitative Evaluation Data. American Journal of Evaluation, 27(2), 237-246. https://doi.org/10.1177/1098214005283748

Van Cott, D. (1994). Indigenous Peoples and Democracy in Latin America. Palgrave Macmillan.

Vazquez, A. (2017). "Programa Cuenca Poopó” Un caso de cooperación al desarrollo de la UE en bolivia [power point slides].

Vega, E. (2013). Decolonisation and dismantling patriarchyl for 'living well' In Beyond Development Alternative visions from Latin America. Transnational Institute / Rosa Luxemburg Foundation

Veltmeyer, H. (2012). The Natural Resource Dynamics of Postneoliberalism in Latin America. Studies in Political Economy 90

Veltmeyer, H. (2013). The Political Economy of Natural Extraction a New Model or Extractive Imperialism. Canadian Journal of Development Studies / Revue canadienne d'études du développement, 34:1, 79-95

Vidaurre, P., Paniagua, N., \& Moraes, M. (2006). Etnobotánica en los Andes de Bolivia. Botánica Económica de Los Andes Centrales, (January), 224-238. https://doi.org/10.1002/jssc.201100169

Villegas, P. (2014). Ley de minería a costa de la democracia. PetroPress, 27, 26-29. Retrieved from https://cedib.org/wp-content/uploads/2014/10/ley-mienria- 
democracia.pdf

Vinthagen, S., Johansson, A. (2013). "Everyday Resistance”: Exploration of a concept and its theories. Resistance Studies Magazine, 1. 1-46. Retrieved from https://pdfs.semanticscholar.org/4c41/37a422db492193fdb521609be218a60a4fd2. pdf

Wang, C \& Burris, M. (1997). Photovoice: Concept, Methodology, and Use for Participatory Needs Assessment. Health Educaiton \& Behavior, 24 (3), 369-387

Wallerstein, I. (1974) The Modern World-System, Vol. 1: Capitalist Agriculture and the Origins of the European World-Economy in the Sixteenth Century. New York/London: Academic Press.

Webber, J. R. 2011. From Rebellion to Reform in Bolivia. Class Struggle, Indigenous Liberation and the Politics of Evo Morales. Haymarket Books, IL.

Webber, J. R. 2014. Managing Bolivian Capitalism. The Jacobin, 33.

Webber, J. R. 2014b. Revolution against 'Progress': Neo-Extractivism, the Compensatory State, and the TIPNIS Conflict in Bolivia. In Spronk, S. \& Webber, J. Crisis and Contradiction: Marxist Perspectives on Latin America in the Global Political Economy. 2014.

Webber, J. 2015. Burdens of a State Manager. Viewpoint Magazine. Retrieved from https://viewpointmag.com/2015/02/25/burdens-of-a-state-manager/

Webber, J. R. (2016). Evo Morales and the political economy of passive revolution in Bolivia, 2006-15. Third World Quarterly, 37(10), 1855-1876. https://doi.org/10.1080/01436597.2016.1175296

Webber, J. (2017). The Last Day of Oppression, and the First Day of the Same: The Politics and Economics of the New Latin American Left. Chicago, IL. Haymarket Books.

Wright, E. (1997). Class Analysis, chapter 1 in Class Counts. Cambridge University Press. 
Wright, E. (2005). Introduction," and Ch. 1 Foundations of a neo-Marxist Class Analysis. In Approaches to Class Analysis. New York: Cambridge University Press.

Zapata Silva, 2006. Los Intelectuales Indigenas y la Representacion. Una Aproximacion a la Escritura de Jose Jara y Silvia Rivera Cusiqanqui. Historia Indigena, 9, 51-84

Zenteno, H. (2009). Acercamiento a la visión cósmica del mundo Andino. Punto Cero, 14(18), 83-89. Retrieved from http://www.scielo.org.bo/scielo.php?script=sci_arttext\&pid=S1815$02762009000100010 \& \operatorname{lng}=\mathrm{es} \& \mathrm{nrm}=\mathrm{iso}$

Zizek, Slavoj (1997). "Multiculturalism or the Cultural Logic of Multinational Capitalism", en New Left Review, No. 225: 28-51

Zamosc, L., 1994. 'Agrarian protest and the Indian movement in the Ecuadorian highlands', Latin American Research Review, 29, 3, pp. 37-65

Zuazo, A. (n.d). Cuando Bolivia vivia del Estaño. Retrieved from http://historiasbolivia.blogspot.com/2017/08/cuando-bolivia-vivia-del-estano.html 


\section{Appendix A.}

\section{Informed consent forms for all participants}

\section{PSU CONSENTIMIENTO PARA PARTICIPAR EN INVESTIGACIÓN}

Bolivia: Perspectivas Comunitarias sobre la extracción de Mineral

Jose Padin, Investigador Principal (PI) y Gisela Rodríguez (Co-PI).

\section{1: formulario de consentimiento verbal no escrito}

Hola, Mi nombre es Gisela Rodriguez, estudiante de doctorado en la universidad del estado de Portland, OR (PSU) y trabajo conjuntamente con el Dr. Jose Padin, professor de la misma universidad. Yo soy de La Paz pero mi familia es de aquí, de Oruro.

Actualmente estoy haciendo un estudio sobre las experiencias de los miembros de la comunidad relacionadas con la mineria. Creo que muy a menudo no escuchamos las historias y realidades de la gente de las comunidades como tú, que viven dia a día los efectos de la mineria. Mi investigación incluye observación participante en reuniones y eventos públicos. Esto significa que yo voy tomando notas de mis observaciones en esta reunión y las reuniones futuras. Sin embargo, debo obtener su consentimiento para incluir las observaciones de su participación en cualquier reunión. Si usted da su consentimiento para ser incluido en mi observación, escribire notas relacionadas con su comportamiento, o las acciones en esta reunión. Cada intento se hará para mantener su identidad confidencial. Mis notas se almacenará en un gabinete bloqueado y sólo yo y mi asesor tendrá acceso a los datos. Si usted da su consentimiento para ser incluido en mis notas de campo, le asigno un seudónimo que se utilizará en todas las publicaciones y presentaciones relacionadas con esta investigación. Sin embargo, existe la posibilidad de que su historia podría ser identificada en los detalles de la reunión y por lo tanto, la confidencialidad no puede ser 100 por ciento garantizado.

Si usted no quiere ser incluido en mis notas de campo, me abstendré de escribir notas relacionadas a su participación en esta reunión. Su participación en este proyecto de investigación es totalmente voluntaria. Si usted da su consentimiento para ser incluido en mis notas, pero cambia de opinión en el futuro, usted es libre de optar por no participar en este proyecto de investigación en cualquier momento. Si en aquel momento no he publicado ninguna resultados relacionados con su participación, me abstendré de hacerlo. Su opción de participar en esta investigación o negarse a participar no afectará su relación conmigo o cualquier persona involucrada en esta investigación de ninguna manera. No hay previsibles beneficios directos para usted para tomar parte en esta investigación. Sin embargo, espero que esta investigación beneficiará a aquellos que deseen comprender mejor y mejorar la realidad de su comunidad. Por favor responder con un "sí" verbal si usted da su consentimiento para ser incluido en mis notas de observación. Por favor responder con un "no" verbal si no acepta y desea ser excluido de mis notas de observación. 


\section{Bolivia: perspectivas comunitarias sobre la mineria y sus efectos socio-ambientales}

\section{2: Documentación del consentimiento informado para las entrevistas}

Buenas tardes, mi nombre es Gisela Rodriguez, soy estudiante de doctorado y trabajo conjuntamente con Dr. Jose Padin, professor en la universidad del estado de Portland, OR (PSU). Esta forma explica este proyecto de investigación. Su participation es voluntaria y puede negarse a participar en cualquier momento. Si usted decide participar, favor de firmar este consentimiento después de leerlo. Debe tener por lo menos 18 años de edad para participar. No dude en hacer preguntas en cualquier momento.

¿De qué trata este estudio? Este estudio explora las perspectivas y experiencias de miembros de la comunidad sobre los efectos de la minería. Este proyecto es independiente de cualquier ONG, grupo local o nacional o afiliación de gobierno. Esto es parte de los estudios de posgrado mios (Gisela) en la Universidad del Estado de Portland, OR (PSU)

¿Qué pasará si decido participar? Si usted decide participar, le hare una entrevista por unos 45 y 90 minutossobre su experiencia y perspectivas sobre la mineria. Esto ocurrirá en un tiempo y lugar de su elección. Si usted está de acuerdo, la entrevista se grabara para que yo (Gisela)pueda recordar su punto de vista. Si esta grabacion le hace sentir incomodo/a, podemos pararla en cualquier momento. Su participación en este proyecto es totalmente voluntaria. No tiene que participar si no quiere. Su decisión de participar o no participar no afectará su relación conmigo (Gisela)y tambien salirse en cualquier momento sin consecuencias. Si participa y luego decidi salirse, sus respuestas no se incluirán en las publicaciones finales.

¿Cuáles son los riesgos de estar en este estudio? Compartir su punto de vista puede ser muy personal y puede traerle recuerdos incomodos. En el caso que encuentre alguna pregunta incómoda, puede saltarla o dejar de participar en cualquier momento. Yo hare todo lo posible de mantener su identidad confidencial usando un apodo y no su nombre real. Sólo yo (Gisela)tendre acceso a los datos originales. Hare todo lo posible para mantener su confidencialidad. Sin embargo, existe la posibilidad de que las historias de los participantes puedan ser identificados y por lo tanto no puede garantizarse su confidencialidad al 100 por ciento. No dude en solicitar más información sobre los riesgos y molestias en cualquier momento.

¿Cuáles son los beneficios de estar en este estudio? No hay beneficios directos para usted. Sin embargo, esperamos que esta investigación beneficie a usted y otras personas al proporcionar informacion que conduzca a políticas más inclusivas relacionadas con la mineria

¿Preguntas o inquietudes? Si usted tiene preguntas o inquietudes acerca de su participación en este estudio, usted puede comunicarse con la oficina de investigación de integridad institucional en PSU al telefono (503) 725-2227 o 1 (877) 480-4400 o 1600

SW 4th Ave., Edificio del centro de mercado, Ste 620, Portland, OR 97201. Si usted tiene preguntas acerca del estudio de sí mismo, por favor póngase en contacto con Gisela Rodriguez (yo) o Jose Padin en (503) 725-3926. 
Su firma indica que ha leído y entendie la información anterior y esta de acuerdo en participar en este estudio. Por favor, entienda que usted puede retirar su consentimiento en cualquier momento sin penalización. Yo le proporcionare una copia de este formulario. Gracias por su participación.

Yo doy permiso para tomar fotos mias en eventos públicos para ser incluidos en las publicaciones (impresos o en línea): __ SI _ NO

Nombre/testigo Firma $\quad$ Fecha

\section{3: documentación del consentimiento informado para Grupos Focales}

(Para los participantes que son incapaces de leer y escribir, se solicitará un consentimiento verbal y el ayudante de campo firmara como testigo del consentimiento verbal)

Hola y gracias por su tiempo. Les invitamos a participar en un proyecto de investigación sobre las experiencias y perspectivas de la comunidad en la extracción de minerales y en los últimos 10 años. Esta forma explica el proyecto de investigación, así como los posibles riesgos y beneficios para usted. No tienes que participar si no desea y puede negarse a participar en cualquier momento. Si usted decide participar, favor de firmar este consentimiento después de la lectura y también recibirá una copia para mantener. Debe ser por lo menos 18 años de edad para participar. No dude en hacer preguntas en cualquier momento.

¿De qué trata este estudio?

Este estudio explora las perspectivas y experiencias de miembros de la comunidad, las mujeres indígenas especialmente con extracción de minerales y en los últimos 10 años. Los objetivos de este estudio son 1) para entender cuáles son las similitudes y diferencias de la extracción minera en los últimos 10 años; 2) para comprender el papel del gobierno meditar los efectos socio-ambientales de la extracción de minerales. Esperamos que los resultados de esta investigación ayudará a informar a su comunidad y diferentes actores en la creación de políticas socio-ambientales sobre la extracción de minerales son más sensibles a y apoyo a las necesidades de los miembros de la comunidad, especialmente mujeres indígenas. Identificaron como potencial participante en este estudio debido a es de vive en esta comunidad y por lo tanto tiene una experiencia directa con estos temas. Este proyecto es independiente de cualquier ONG, grupo local o nacional o afiliación de gobierno. Esto es parte de Gisela estudios de posgrado en la Universidad de estado de Portland (PSU).

¿Qué pasará si decido participar?

Si usted decide participar en este estudio, se le pedirá participar en un grupo de enfoque con otros 4-6 personas de su comunidad y Gisela (yo) será el facilitador. Esta charla duran entre 45 y 90 minutos y se suceden en un momento y determinar. Durante este tiempo, Gisela le preguntará a usted y otras personas para hablar de su experiencia y perspectivas sobre la extracción de minerales. Si está de acuerdo a él, la discusión de 
grupo de enfoque será grabada para que Gisela puede registrar con precisión las respuestas a las preguntas. También puede solicitar que deje nuestra Tipografia pausa en cualquier momento te hace sentir incómodo.

$\mathrm{Su}$ participación en este proyecto es totalmente voluntario. No tienes que participar si no quiere. Su decisión de participar o no participar no afectará su relación con Gisela o cualquier persona involucrada en este proyecto de ninguna manera. Incluso si se empieza el estudio, puede salir en cualquier momento sin consecuencias negativas. Si participar y decidir a parar parcialmente a través de, continuará el audio de la charla, pero no se hará transcripción ni análisis acerca de su participación y sus respuestas no se incluirán en las publicaciones finales.

¿Cuáles son los riesgos de estar en este estudio?

Porque diciendo su punto de vista puede ser muy personal y traer experiencias y recuerdos distintos, existen riesgos potenciales de la incomodidad, molestias y pérdida de privacidad y confidencialidad relacionadas a participar en cualquier estudio de investigación. Sin embargo, en el caso que encuentres alguna pregunta incómoda, puede saltarlos o dejar de participar en cualquier momento. Si te animas a participar, cada intento se hará para mantener su identidad confidencial. Su información personal (nombre, dirección) se mantendrá confidencial en toda la documentación. Las entrevistas grabadas se transcribe (escrito) y se almacenarán las versiones de audio y escritas en una computadora protegida por contraseña. Sólo Gisela y su asesor tendrá acceso a los datos. Si usted decide participar, se le asignará un seudónimo y no se incluirá su nombre en publicaciones o presentaciones relacionadas con esta investigación. Todo lo haremos posible para mantener la confidencialidad del tema de investigación. Sin embargo, tenga en cuenta que la naturaleza de grupos de enfoque es tal que no se garantiza totalmente la confidencialidad. Antes de cada grupo, Gisela recordará a los participantes de la importancia de la confidencialidad y animará a los participantes a mantener la confidencialidad de lo que escuchan durante las reuniones. No dude en solicitar más información sobre los riesgos y molestias en cualquier momento.

¿Cuáles son los beneficios de estar en este estudio?

No hay previsibles beneficios directos a usted por participar en el estudio. Sin embargo, esperamos que esta investigación beneficiará usted y otras personas al proporcionar un canal para que sus voces sean escuchadas y que esto conducirá a más inclusivas políticas relacionadas con la extracción de minerales.

¿Preguntas o inquietudes?

Si usted tiene preguntas o inquietudes acerca de su participación en este estudio o sus derechos como participante, usted puede comunicarse con la oficina de investigación integridad institucional de PSU a (503) 725-2227 o 1 (877) 480-4400 o 1600 SW 4th Ave., Edificio del centro de mercado, Ste 620, Portland, OR 97201. Si usted tiene preguntas acerca del estudio de sí mismo, por favor póngase en contacto con Gisela Rodriguez (yo) o Jose Padin en (503) 725-3926

Su firma indica que ha leído y entender la información anterior y de acuerdo a participar en este estudio. Por favor, entienda que usted puede retirar su consentimiento en cualquier momento sin penalización. El investigador le proporcionará una copia de este formulario para sus propios registros.

Gracias por tu participación. 
Yo doy permiso de incluir fotos de mí tomadas en eventos públicos o grupos focales en las publicaciones (impresos o en línea): no

Fecha 


\title{
Appendix B. Verbal script for recruitment
}

\author{
PSU guiones verbales para reclutamiento de participantes \\ Bolivia: Perspectivas Comunitarias sobre la extracción de Mineral \\ Jose Padin, Investigador Principal (PI) y Gisela Rodríguez (Co-PI).
}

\section{a) Guiones verbales para reclutar miembros de la comunidad}

Buenos dias/tardes, mi nombre es Gisela, soy de La Paz pero mi familia es de aquí, de Oruro. Actualmente estoy haciendo un estudio sobre las experiencias y perspectivas de la comunidad en la minería. El objetivo es entender lo que ha mejorado y lo que se podría mejorar. Creo que muy a menudo no escuchamos las historias y realidades de la gente de las comunidades como tú, que los efectos cotidianos de la experiencia extracción de minerales. Si usted decide participar, le pedirá que tome parte en una entrevista de 45 a 90 minutos en un momento y lugar de su elección. Su participación en este proyecto es totalmente voluntario. Su decisión de participar o no participar no afectará su relación conmigo o cualquier persona involucrada en este estudio de ninguna manera. Antes de explicar más detalles sobre este estudio, por favor, Déjame hacerte unas preguntas:

1. ¿quieres participar? Sí (siga) No (gracias a participante por su tiempo y dejar)

2. ¿Cuánto tiempo has vivido en esta comunidad? (Menos de 5 años parada y gracias a participante por su tiempo y dejar) (5 o más de 5 años, continuar).

5. ¿piensa que usted o su familia ha sido afectada por la minería? (en caso afirmativo, pasar a script, si no es así, detener y gracias a participante por su tiempo y dejar)

\section{Continuación del guion.}

Gracias por contestar a estas preguntas. Parece que seas una gran persona a hablar con estos temas. ¿Quieres saber más acerca de la entrevista? \{Si te dicen que quieren aprender más, entonces iré sobre los datos en el formulario de consentimiento y una cita para revisar y completar el proceso de consentimiento y realizar la entrevista. Si el participante necesita intérprete para la entrevista, y que coordinará la entrevista para asegurarse de que el intérprete está disponible. Sin embargo, el censo de 2012 del Instituto Nacional de estadística muestra que las comunidades campesinas indígenas en este municipio son bilingües (español y Quechua); por lo tanto, la necesidad de un intérprete no se espera\}

\section{b) Guion verbal para actores claves comunitarios}

(estos actores serán previamente identificados durante un mapeo de actores claves de la comunidad durante la preparación in situ de trabajo de campo, así como durante las entrevistas con miembros de la comunidad) 
Buenos dias/tardes, mi nombre es Gisela, soy de La Paz pero mi familia es de aquí, de Oruro. Actualmente estoy haciendo un estudio sobre las experiencias y perspectivas de la comunidad en relación con la extracción de minerales en los últimos 10 años. Mi objetivo es entender lo que ha mejorado y lo que se podría mejorar. Creo que muy a menudo no escuchamos las historias y realidades de la gente de las comunidades como tú, que experimentan los efectos cotidianos de la extracción de minerales. Yo lo identifico como un participante potencial porque diferentes personas mencionaron a usted como un importante actor/líder de la comunidad involucrado en una u otra manera sobre este tema. Si usted decide participar, le pedirá que tome parte en una entrevista de 45 a 90 minutos en un momento y lugar de su elección. Su participación en este proyecto es totalmente voluntario. Su decisión de participar o no participar no afectará su relación conmigo o cualquier persona involucrada en este estudio de ninguna manera. ¿Quieres saber más acerca de la entrevista? \{Si te dicen que quieren aprender más, entonces iré sobre los datos en el formulario de consentimiento y una cita para revisar y completar el proceso de consentimiento y realizar la entrevista. Si el participante necesita intérprete para la entrevista, entonces se coordino la entrevista para asegurarse de que el intérprete está disponible. Sin embargo, el censo de 2012 Instituto Nacional de estadística muestra que las comunidades campesinas indígenas en este municipio son bilingües (español y Quechua); por tanto, no se prevé la necesidad de un intérprete)

\section{c) Guion verbal para ONGs e instituciones nacionales}

(La mayoría de estos actores ya se identificaron basados en el análisis de varios documentos. Seran también identificados durante un mapeo de actores claves comunitarios y ONGs durante la preparación in situ de trabajo de campo)

Buenos dias/tardes, mi nombre es Gisela Rodriguez, soy un candidato al doctorado en Sociología en la Universidad Estatal de Portland (PSU) en Estados Unidos y actualmente estoy haciendo investigación sobre las experiencias y perspectivas de la comunidad en las zonas rurales sobre la extracción de minerales en los últimos de 10 años. Mi objetivo es entender lo que ha mejorado y lo que se podría mejorar. Parece que esta ONG juega un papel importante en las raíces de la hierba organizar dentro de estas comunidades y por lo tanto me gustaría conocer su punto de vista y experimentar así. Si usted decide participar, le pedirá que tome parte en una entrevista de 45 a 90 minutos en un momento y lugar de su elección. Su participación en este proyecto es totalmente voluntario. Su decisión de participar o no participar no afectará su relación conmigo o cualquier persona involucrada en este estudio de ninguna manera. ¿Quieres saber más acerca de la entrevista? \{Si dicen que quieren aprender más, entonces iré sobre los datos en el formulario de consentimiento y una cita para revisar y completar el proceso de 
consentimiento y realizar la entrevista.

\section{d) Guion verbal para funcionarios}

(La mayoría de estos actores ya se identificaron en función de su posición en las oficinas del gobierno, tales como los ministerios de Desarrollo Rural, desarrollo económico y el Viceministerio de descolonización)

Buenos días/tardes, mi nombre es Gisela Rodriguez, soy un candidato al doctorado en Sociología en la Universidad Estatal de Portland (PSU) en Estados Unidos y actualmente estoy haciendo una investigación sobre las experiencias y perspectivas de las personas en las zonas rurales sobre la extracción de minerales. Ha habido algunas críticas con respecto a las políticas del gobierno en la extracción. Por lo tanto, me gustaría entender estas cuestiones desde su perspectiva. Me gustaría conocer su perspectiva sobre lo que ha mejorado, lo que podría mejorarse, y cuáles son los principales obstáculos. Si usted decide participar, le pedirá que tome parte en una entrevista de 45 a 90 minutos en un momento y lugar de su elección. Su participación en este proyecto es totalmente voluntario. Su decisión de participar o no participar no afectará su relación conmigo o cualquier persona involucrada en este estudio de ninguna manera. ¿Quieres saber más acerca de la entrevista? \{Si te dicen que quieren aprender más, entonces iré sobre los datos en el formulario de consentimiento y una cita para revisar y completar el proceso de consentimiento y realizar la entrevista.\}

\section{e) Guion verbal para grupos focales}

Buenos días/tardes, mi nombre es Gisela, soy de La Paz pero mi familia es de aquí, de Oruro. Actualmente estoy haciendo un estudio sobre las experiencias y perspectivas de la comunidad en la extracción de minerales en los últimos 10 años. Mi objetivo es entender lo que ha mejorado y lo que se podría mejorar. Creo que muy a menudo no escuchamos las historias y realidades de la gente de las comunidades como tú, que experimentan los efectos cotidianos de la extracción de minerales. Si usted decide participar, les pido a participar en una discusión de grupo de 45 a 90 minutos con otro 4-6 miembros de la comunidad en un momento y lugar de su elección. Su participación en este proyecto es totalmente voluntario. Su decisión de participar o no participar no afectará su relación conmigo o cualquier persona involucrada en este estudio de ninguna manera. Antes de explicar más detalles sobre este estudio, por favor, Déjame hacerte unas preguntas:

1. ¿quieres participar? Sí (siga) No (gracias a participante por su tiempo y dejar)

2. ¿Cuánto tiempo has vivido en esta comunidad? (Menos de 5 años parar y dar gracias a 
participante por su tiempo y dejar) (5 o más de 5 años, continuar).

3. ¿trabaja en las minas? (en caso afirmativo, vaya al guión para las entrevistas individuales, si no, continuar con preguntas)

4. ¿piensa que usted o su familia ha sido afectada por la minería? (en caso afirmativo, pasar a script, si no es así, detener y gracias a participante por su tiempo y dejar)

\section{Continuación del guion.}

¿Quieres saber más acerca de la entrevista? \{Si te dicen que quieren aprender más, entonces iré sobre los datos en el formulario de consentimiento y una cita para revisar y completar el proceso de consentimiento y realizar la entrevista. Si el participante necesita intérprete para la entrevista, entonces se coordino la entrevista para asegurarse de que el intérprete está disponible. Sin embargo, el censo de 2012 Instituto Nacional de estadística muestra que las comunidades campesinas indígenas en este municipio son bilingües (español y Quechua); por lo tanto, la necesidad de un intérprete no se espera\}

\section{f. breve cuestionario}

(Para aplicarse antes de entrevistas, grupos focales y photovoice. Se utilizará para propósitos demográficos o presentar características generales de los participantes)

$\mathbf{N}$ de la

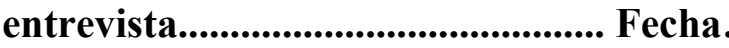

\section{Ubicación.}

.COMUNIDAD.

Nombre Seudónimo

Sexo Edad del

participante.

Estado civil. Número de niños.

Nivel de educación Afiliación

religiosa

Idiomas:

primario. Secundario.

¿Usted se identifica como originario indígena

campesino?

¿Trabaja? Donde? 
¿Le pagan por su

trabajo? Sí............................. No.

es o fue líder/autoridad de su comunidad?

que posición?

\section{Características del hogar}

Donde vive?

¿Cuántas personas viven con

usted?

¿Usted tiene casa propia o alquila?

¿Tiene un baño en su

casa? Sí. No.

¿Tiene una cocina en su

casa? Sí. No

¿Tienes acceso a combustibles de

cocina? Sí. No.

$¿$ Tienes electricidad en su

casa? Sí. No.

$¿$ Tiene acceso a agua en su

casa? Sí. No.

¿Tiene acceso a agua cerca de su casa? Sí... ..No

\section{Condición social de las mujeres}

Se le permite ser dueña de su casa o su

terreno?

Quién toma la decisión en su

casa?.

Puede usted tomar decisiones?

Notas : 


\section{Appendix C. Interview guides}

\section{PSU guia de entrevistas con participantes}

Bolivia: perspectivas comunitarias sobre los efectos socio-ambientales de la minería jose Padin, Investigador Principal (PI) y Gisela Rodríguez (Co-PI).

\section{1: Guia de entrevistas con miembros de la comunidad}

\section{Antecedentes}

- Gracias por sus respuestas al cuestionario. Ahora me gustaría saber mas de usted. ¿Cuánto tiempo tiene usted viviendo en esta comunidad? ¿Nacio aquí? ¿Si no, de Donde viene y desde cuando vive aqui?

- Vive también en otro lugar? Donde y porque?

- ¿Tienes mascotas o animales, ovejas, vacas?

- ¿En el cuestionario, usted se identifico como indígena, que significa esto para usted o como describiría ser indígena a alguien que fuera de otro pais?

\section{Preguntas sobre la extracción minera}

- Ahora me gustaría saber su opinión sobre la minería. En primer lugar, ¿qué empresa minera esta afectando a su comunidad y desde cuando?

- ¿y Cómo cree que la minera ha afectado a su comunidad? En términos generales; En relación con la agricultura; en relación con la tierra, agua y otros recursos; ¿en las relaciones entre los miembros de la comunidad?

- ¿Y cómo la minería le afecta a usted y a su familia en el dia a dia de su vivir? Pensando mas que nada en los quehaceres del hogar, en cuidar a sus hijos, en cuidar a su ganado, en producir su comida, en asegurar que haya comida..

- ¿y la mineria ha afectado su trabajo? ¿Cómo?

- ¿La minería produce trabajo para la gente en su comunidad?

- ¿y produce Trabajo para las mujeres?

- Según usted, ¿cuál ha sido el mayor reto con respecto a los efectos de la minería para usted y su comunidad?

- ¿Hay diferencia entre los efectos de las cooperativas, las minas nacionalizadas y las minas privatizadas? Si es que sí, ¿cuáles son estas diferencias?

- ¿Crees que hay algunos aspectos positivos sobre la minería para usted? ¿si es que si, cuáles?

- ¿algo mas sobre la minería que considere importante compartir?

\section{Preguntas sobre el gobierno}

Ahora me gustaría preguntarte sobre el gobierno de Evo Morales con relación a la minería

- ¿Ha notado algún cambio en las empresas mineras en los últimos 10 años o desde que el presidente Evo ha sido presidente? Si es que si ¿cómo?

- ¿y Cómo describiría usted la relación entre el gobierno y las empresas mineras? Conflictiva, con interés a fin, igual que antes.

- ¿Cómo ha afectado esta relación entre el gobierno y las mineras a su comunidad?

- ¿y Cómo esta relación ha afectado su vida? 
- Que le pide su comunidad al gobierno con respecto a la minería, osea que es lo que quieren que cambie?

- si pudiera pedirle algún cambio al gobierno con respecto a la minería, que pediría usted? que demandas tiene su comunidad Que quisiera que solucione y que quisiera que cambie?

- Y Qué opina usted en general sobre el gobierno de Evo Morales? (usted antes apoyaba a Evo, porque si o porque no?

- ¿Ha notado algunas diferencias en su comunidad desde la elección del presidente Morales? Si es que si ¿cuáles son estos cambios?

- ¿Cree que su comunidad está políticamente más empoderada ahora con la Presidencia de Evo que antes? Sí/no: si es así, ¿de qué manera?

- ¿Ha habido cambios en las formas en que su comunidad toma decisiones acerca de los efectos de la minería en los últimos 10 años? Si es así, ¿cuáles son los cambios?

- ¿y como ha sido el proceso de consulta previa e informada? Conoce usted sobre esto?

- He oído mucho hablar de 'desarrollo'. ¿Qué significa para usted esta palabra?

- Usted ha mencionado ser indígena, ¿crees que el gobierno (que dice ser indígena) representa sus intereses como una mujer indígena?

- ¿Qué tal tus hijos y su comunidad? ¿Crees que el gobierno y su relación/posición a la minería está creando un futuro mejor para tus hijos?

\section{Agencia}

- y usted conoce sobre la CORIDUP, que es esto y que hace?

- Y su comunidad que estrategias utiliza para mejorar las condiciones de vida de los y las comunarias? Osea, organiza reuniones, planea protestas, organiza como traer agua en conjunto, etc?

- ¿y usted? Cuáles son las estrategias que USTED utiliza para continuar sus actividades diarias en medio de tantas dificultades, en especial los efectos de la minería?

- Y sobre su futuro. ¿Cómo se ve usted y a su comunidad en 10 años?

- ¿se siente más empoderada ahora bajo la Presidencia de Evo? Si sí o no, ¿cómo?

- ¿Ha oído hablar de sumaq kawsay (la filosofía de vivir bien)? ¿Qué significa esto para usted?

- (si oído hablar de ésto) ¿cómo esta filosofía le ayuda en su vida diaria?

- Y la Pachamama? Como usted cuida a la Pachamama? Y el gobierno, cuida a la Pachamama? Que tal las mineras? Como usted aconsejaría al gobierno y a las mineras cuidar a la Pachamama...(paxi-mama?)

- ¿Hay algo más que considere importante compartir que yo no le haya preguntado? 


\section{Guia de entrevistas con actores clave de la comunidad}

Antecedentes

Gracias por sus respuestas al cuestionario. ahora me gustaría hablar más acerca de usted.

- ¿Cuánto tiempo tiene usted viviendo en esta comunidad? ¿Nacio aquí? ¿Si no, Donde y desde cuando vive aquí?

- ¿En el cuestionario, usted se identifico como indígena, que significa esto para usted o como le explicaría a alguien de otro lugar que es ser indígena? Cual es la diferencia entre campesino e indígena, es lo mismo?

- ¿conoce la historia de su comunidad,? ¿Por ejemplo, Cuándo fue creada? ¿Hubo algunos cambios importantes como la migración o la llegada de las organizaciones/instituciones/corporaciones en los últimos 10 años?

- ¿Cuál es su papel dentro de la comunidad? ¿Cuánto tiempo ha tenido usted este papel? ¿Cómo fueron elegida para este papel?

- (que autoridades tiene su comunidad/región?)

- (para autoridades originarias: me podría explicar que es el $\boldsymbol{A L L Y U}$ ?)

- ¿Es parte de alguna otra organización? ¿En caso de que si, podría compartir la misión de esta organización y que hacen?

\section{Preguntas sobre Extracción mineral}

- Ahora me gustaría saber su opinión sobre la minería. En primer lugar, ¿qué empresa minera esta afectando a su comunidad y desde cuando?

- ¿y como ha afectado a su comunidad? En términos generales; En relación con la agricultura; en relación con la tierra, agua y otros recursos; ¿en las relaciones entre los miembros de la comunidad?

- ¿Y cómo la minería le afecta a las mujeres de su comunidad en el dia a dia de su vivir? Pensando en los quehaceres del hogar, cuidar a sus hijos, cuidar a su ganado, los animalitos, en producir su comida, en asegurar que haya comida, agua para lavar la ropa, etc.

- Según usted, ¿cuál ha sido el mayor reto con respecto a la minería para su comunidad?

- ¿Hay diferencia de efectos entre cooperativas, minas nacionalizadas y minas privatizadas? Es sí, ¿cuáles son estas diferencias?

- ¿la Minería produce trabajo para la gente en su comunidad? Hay gente de su comunidad que trabaja en las mineras? ¿y trabajo para las mujeres?

- ¿y la minería ha afectado su posición como xxxxx? ¿en que sentido?

- ¿Crees que hay algunos aspectos positivos sobre la minería para usted? ¿ cuáles?

Preguntas sobre el gobierno ahora me gustaria preguntarle sobre el gobierno de Evo Morales y la mineria.

- ¿Ha notado algún cambio en las empresas mineras en los últimos 10 años o desde que Evo es presidente? Si es que si, ¿cómo así?

- ¿Nota algunas contradicciones entre lo que dice el gobierno sobre la minería, la madre tierra y lo que sucede en su comunidad? si es que si, ¿cómo?

- ¿Cómo describiría usted la relación entre el gobierno y las empresas mineras? Como una relación conflictiva, que se llevan bien, se contradice, es algo complicada?

- ¿y Cómo ha afectado esta relación entre el gobierno y las mineras a su comunidad? 
- ¿y Cómo esta relación ha afectado a las mujeres de su comunidad?

- Que le pide su comunidad al gobierno con respecto a la minería, osea que es lo que quieren que cambie?

- si pudiera pedirle algún cambio al gobierno con respecto a la minería, que pediría usted? que demandas tiene su comunidad Que quisiera que solucione y que quisiera que cambie?

- y en general, que opina usted del gobierno de Evo Morales?

- ¿Ha notado algunas diferencias en su comunidad desde la elección del presidente Morales? Si es que si ¿cuáles son estos cambios?

- ¿Crees que los mecanismos de participación política son ahora más democráticos que antes? Si es así, ¿cómo son diferentes ahora?

- ¿Cree que su comunidad está políticamente más empoderada ahora con la Presidencia de Evo que antes? Sí/no: si es así, ¿de qué manera?

- ¿Ha habido cambios en las formas en que su comunidad toma decisiones acerca de los efectos de la minería en los últimos 10 años? Si es así, ¿cuáles son los cambios?

- ¿y como ha sido el proceso de consulta previa e informada?

- Y algún cambio en su posición como xxxx? Y porque le dicen mama-talla?

- He oído mucho hablar de 'desarrollo'. ¿Qué significa para usted esta palabra?

- Usted ha mencionado ser indígena, ¿crees que el gobierno (que dice ser indígena) representa sus intereses como una mujer indígena?

- ¿Es ser indígena diferente de ser un ciudadano boliviano? ¿Crees que son los mismos? ¿Hay cambios en estas dos identidades desde la elección del presidente Morales?

- ¿y sobre los derechos indígenas? ¿En qué difieren estos derechos de los derechos del resto de los bolivianos?

- ¿Y cuál es el papel del gobierno en estos derechos?

- ¿Qué tal tus hijos y su comunidad? ¿Crees que el gobierno y su relación/posición a la minería está creando un futuro mejor para sus hijos.

\section{Agencia}

- Y su comunidad que estrategias utiliza para mejorar las condiciones de vida de los y las comunarias? Osea, organiza reuniones, planea protestas, organiza como traer agua en conjunto, etc?

- Y hay algunas estrategias que las mujeres de su comunidad usan para continuar sus actividades diarias en medio de tantas dificultades, en especial los efectos de la minería?

- Y sobre el futuro de su comunidad. ¿Cómo ve usted y a su comunidad en 10 años?

- Y como ve usted a su familia en 10 anos?

- Y como ayuda o puede ayudar la CORIDUP a mejorar este futuro?

- ¿se siente más empoderada ahora bajo la Presidencia de Evo? Si sí o no, ¿cómo?

- ¿Ha oído hablar de sumaq kawsay (la filosofía de vivir bien)? ¿Qué significa esto para usted y su comunidad?

- (si oído hablar de ésto) ¿cómo esta filosofía le ayuda en su vida diaria?

- Y la Pachamama? Como usted su comunidad cuida a la Pachamama? Y el gobierno, 
cuida a la Pachamama? Que tal las mineras? Como usted aconsejaría al gobierachamama...(paxi-mama?)

- ¿Hay algo más que considere importante compartir que yo no le haya preguntado

\section{Guia de entrevista con ong locales e instituciones nacionales Antecedentes}

- Buenas tardes y gracias por tu tiempo y ayuda con este estudio. Me gustaría preguntar ¿cuánto tiempo tiene usted viviendo en esta comunidad? ¿y de dónde eres?

- ¿Y cuánto tiempo han trabajado para esta ONG?

- ¿Si conoces la historia de su ONG, podría compartirlo conmigo? ¿Por ejemplo, Cuándo fue creada? ¿Cuál es la misión y visión?

- ¿Cuál es su posición? ¿Cuánto tiempo ha tenido este papel?

- ¿Cómo se conecta esta ONG para temas de minería?

\section{Preguntas sobre extracción mineral}

- Ahora me gustaría saber sus opiniones sobre la minería. En primer lugar, ¿cuánto tiempo las empresas mineras llevan en la región? Y ¿cuáles son los tipos de explotación minera alrededor de?

- ¿Ha notado cambios dentro y entre las empresas mineras en los últimos 10 años? Si es que si, ¿cómo así?

- ¿Cómo la mineria ha afectado la comunidad en los últimos 10 años? ¿Son estos efectos diferentes de los efectos antes?

- ¿Hay alguna diferencia entre los tipos de minería? ¿Cooperativas, transnacionales, nacionales?

- ¿Qué cree que son los principales impactos de la minería en las comunidades? (En términos generales y en relación con la agricultura, en relación con la tierra, agua, otros recursos)

- ¿Y cuál es el impacto de la minería sobre las mujeres indígenas?

- ¿Qué estrategias tiene su ONG para abordar el impacto de la minería?

- ¿Cuál es el impacto de su ONG en las organizaciónes/organizacion de base comunitaria? ¿Qué tipo de papel su organización juega?

- ¿Qué tipos de demandas apoya su ONG? ¿y cuales no apoya?

\section{Preguntas sobre el gobierno}

Ahora me gustaría preguntarte sobre el gobierno.

- Evo Morales ha sido el Presidente ahora por más de 10 años, desde la perspectiva de la ONG, ¿Qué opinas sobre su gobierno?

- ¿Ha sido este gobierno apoyo de ONG locales como la suya?

- ¿Recibe las subvenciones del gobierno?

- ¿Ha notado algunas diferencias en las comunidades desde la elección del presidente Morales? Si es que si, ¿cuáles son estos cambios? Y ¿sucedió? ¿Cómo explica los?

- ¿Hay contradicciones sobre lo que el Gobierno declara vs las políticas implementa? ¿Sí no? ¿Qué opinas sobre él? 
- Si es que si, ¿cuál es el papel de las ONG locales en estas contradicciones? O cómo como una respuesta de las ONG a estas contradicciones.

- ¿Crees que los mecanismos de participación política son ahora más democráticos que antes? Si es así, ¿cómo son diferentes ahora?

- ¿Cómo usted define empoderamiento? Y ¿Cómo crees que podrían estar capacitados miembros de la comunidad?

- ¿Crees que las comunidades están empoderadas políticamente más ahora con la Presidencia de Evo que antes? Sí/no: si es así, ¿de qué manera?

- ¿En su opinión, todos los miembros de la comunidad han sido empoderados? ¿algunos miembros más que otros? ¿Algunas familias más que otros? Si hay diferencias, ¿cómo podrían explicar esas diferencias? ¿y sobre las mujeres?

- ¿Cómo describiría usted la relación entre el govertment y las empresas mineras?

\section{Indigenismo}

- ¿Cómo define el ser indígena o indigenismo?

- ¿Cuál es la relación de ser indígena y las políticas ambientales que su ONG promueve?

- ¿Hay contradicciones en esta relación?

- ¿que opina sobre el gobierno que dice ser indígena o ser dirigido por un líder indígena?

- ¿Crees que el gobierno representa a los intereses de las comunidades indígenas?

- ¿Es ser indígena diferente de ser un ciudadano boliviano? ¿Crees que son los mismos? ¿Hay alguna posibilidades en estas dos identidades desde la elección del presidente Morales?

- ¿y sobre la identidad indígena y sus derechos? ¿Existen los derechos políticos, económicos o culturales sólo para los pueblos indígenas? ¿En qué difieren los derechos de los derechos del resto de los bolivianos?

- ¿Y cuál es el papel del gobierno en estos derechos?

- ¿Cómo cree que es la relación entre la identidad indígena y el estado en respecto a la herencia colonial de tal identidad? ¿es este diferente, lo mismo?

- ¿Hasta qué punto ha roto con la caracterización colonial de los pueblos indígenas el gobierno de Evo? ¿Cómo el estado ha desafiado las connotaciones racistas contra los pueblos indígenas?

\section{Agencia}

- ¿Otra cosa que quiera compartir no he le haya preguntado?

- ¿Cómo crees que miembros de la comunidad ejercen la Agencia?

- ¿Qué mecanismos apoyan o bloquean la Agencia?

- ¿Tu ONG, ¿cómo apoya la Agencia dentro de las comunidades?

- ¿Son las personas de esta comunidad más empoderadas ahora bajo la Presidencia de Evo? Si sí o no, ¿cómo?

- ¿Has oído hablar de sumaq kawsay (vivir bien)? ¿Qué significa esto para usted como un representante de la ONG y qué cree que significa para las comunidades?

- (si oído hablar de él) ¿cómo esta filosofía ayuda a miembros de la comunidad en su vida diaria? 
- ¿Considera que la identidad indígena es útil para las luchas políticas y económicas en su comunidad? ¿De qué manera? ¿Por qué a nivel nacional?

- ¿Hay algo más su considere importante compartir que yo no le haya preguntado?

\section{4. guías de entrevista con funcionarios del gobierno}

Antecedentes

- Buenas tardes, me gustaría saber primero un poco acerca de usted. Donde está usted y cómo usted se involucró en la política

- ¿Cuál es su posición y cuánto tiempo han trabajado en dicha posición?

- ¿ es usted un miembro de MAS?

Preguntas sobre extractivismo mineral

- ¿Han habido cambios entre las actividades extractivas antes y después de la elección del presidente Morales?

- Algunas personas son críticas sobre las posiciones del gobierno hacia el extractivismo. Me gustaría saber su opinión sobre extractivismo y particularmente sobre la minería.

- ¿Cree que estas son contradicciones válidas? ¿Existen puntos de tensión entre las políticas extractivas del gobierno y las comunidades indígenas?

- ¿hay diferencias entre las cooperativas, las minas nacionalizadas y las multinacionales? ¿Cómo es la relación del gobierno con estos 3 actores?

- ¿En su opinión, quien se está beneficiando de las políticas sociales implementadas por Evo Morales? ¿Todo el mundo, algunos grupos? ¿Algunos grupos ahora y otros más adelante?

- ¿Hay una diferencia entre los tipos de minería? ¿Cooperativas, transnacionales, nacionalizadas?

- ¿Cuales son los principales impactos de la minería en las comunidades? (En términos generales y en relación con la agricultura, en relación con la tierra, agua, otros recursos)

- ¿Y cual es el impacto en las mujeres indígenas?

\section{Preguntas sobre el gobierno}

- Evo Morales ha sido Presidente durante más de 10 años, ¿qué crees que son los principales logros? ¿Cuáles son algunas áreas de mejora?

- ¿Cree que los mecanismos de participación política son ahora más democráticos que antes? Si es así, ¿cómo son diferentes ahora?

- ¿Qué significa para usted «empoderamiento»?

- ¿Crees que las comunidades están empoderadas políticamente más ahora con la Presidencia de Evo que antes? Sí/no: si es así, ¿de qué manera?

- ¿y sobre las mujeres indígenas en las zonas rurales? ¿Cómo se han beneficiado de las políticas sociales del presidente Morales?

\section{Indigenismo}

- ¿Cómo define ser indígena o indigenismo?

- ¿Cuál es la relación de ser indígena y el gobierno? 
- ¿Existen diferencias entre el indigenismo del estado y de las comunidades indígenas?

- ¿Existen diferencias de indigenismo basado en áreas regionales o grupos indígenas?a

- ¿cuáles son los principales beneficios del gobierno ser indígena o ser dirigido por un líder indígena?

- ¿Existen desventajas?

- ¿Cree que el gobierno representa a los intereses de las comunidades indígenas?

- ¿Es ser indígena diferente de ser un ciudadano boliviano? ¿Crees que son los mismos? ¿Hay alguna posibilidades en estas dos identidades desde la elección del presidente Morales?

- ¿y sobre la identidad indígena y los derechos? ¿Existen los derechos políticos, económicos o culturales sólo para personas indigenas? ¿En qué difieren los derechos de los derechos del resto de los bolivianos?

- ¿Y cuál es el papel del gobierno en estos derechos?

- ¿Cómo crees que se relaciona con la identidad indígena que el estado se refiere a la herencia colonial de tal identidad? ¿es este diferente, lo mismo?

- ¿En qué medida se ha roto el gobierno de Evo con la caracterización colonial de los pueblos indígenas? ¿Cómo el estado ha desafiado las connotaciones racistas contra los pueblos indígenas? ¿Cómo?

¿Otra cosa que quieras compartir no le haya preguntado? 